\title{
Gas-Fired Distributed Energy Resource Technology Characterizations
}

\author{
Bringing you a \\ prosperous future where \\ energy is clean, abundant, \\ reliable, and affordable
}

A joint project of the Gas Research Institute (GRI) and the NPE National Renewable Energy Laboratory

Prepared for the Office of Energy Efficiency and Renewable Energy
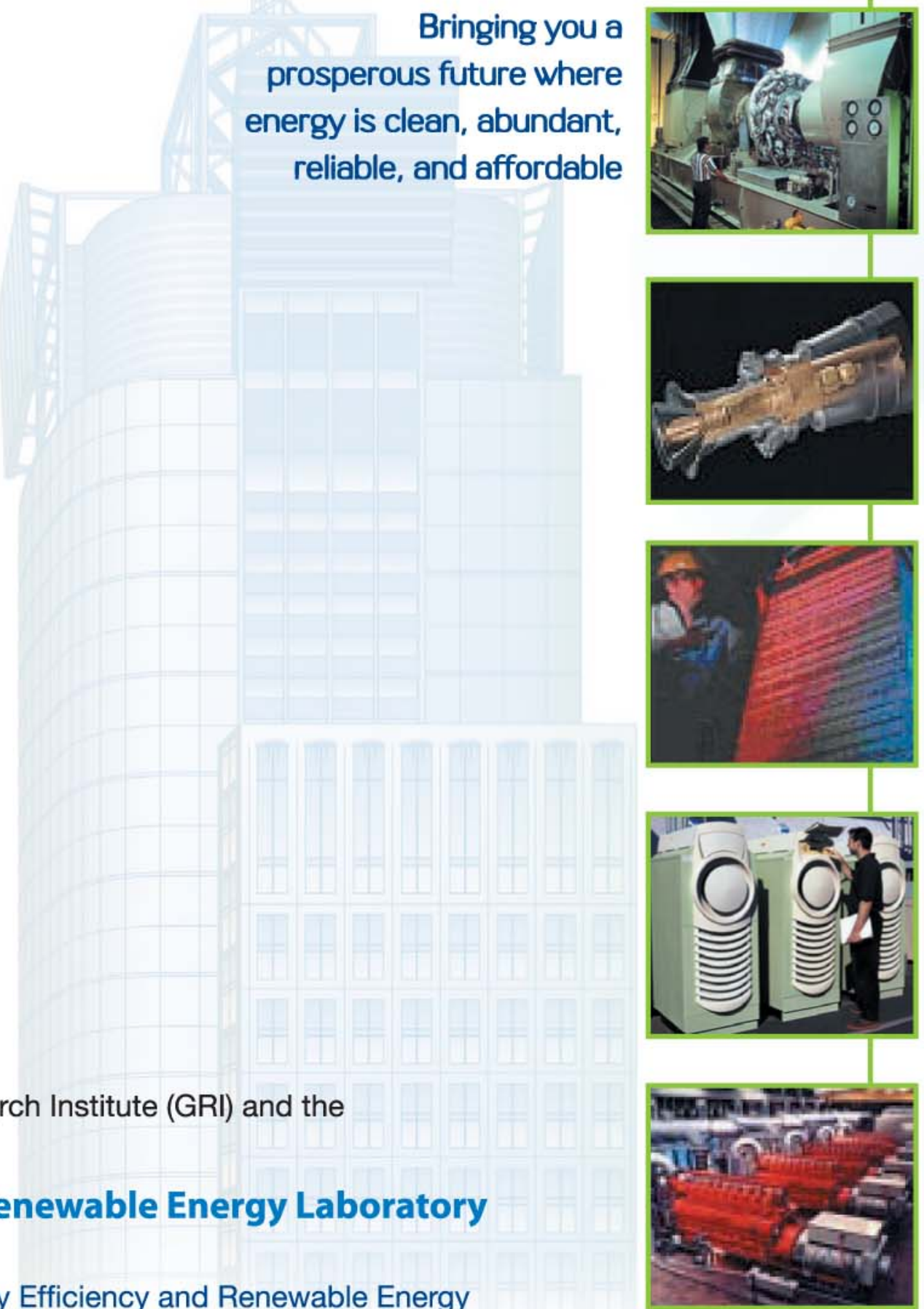

November 2003 • NRELTP-620-34783 


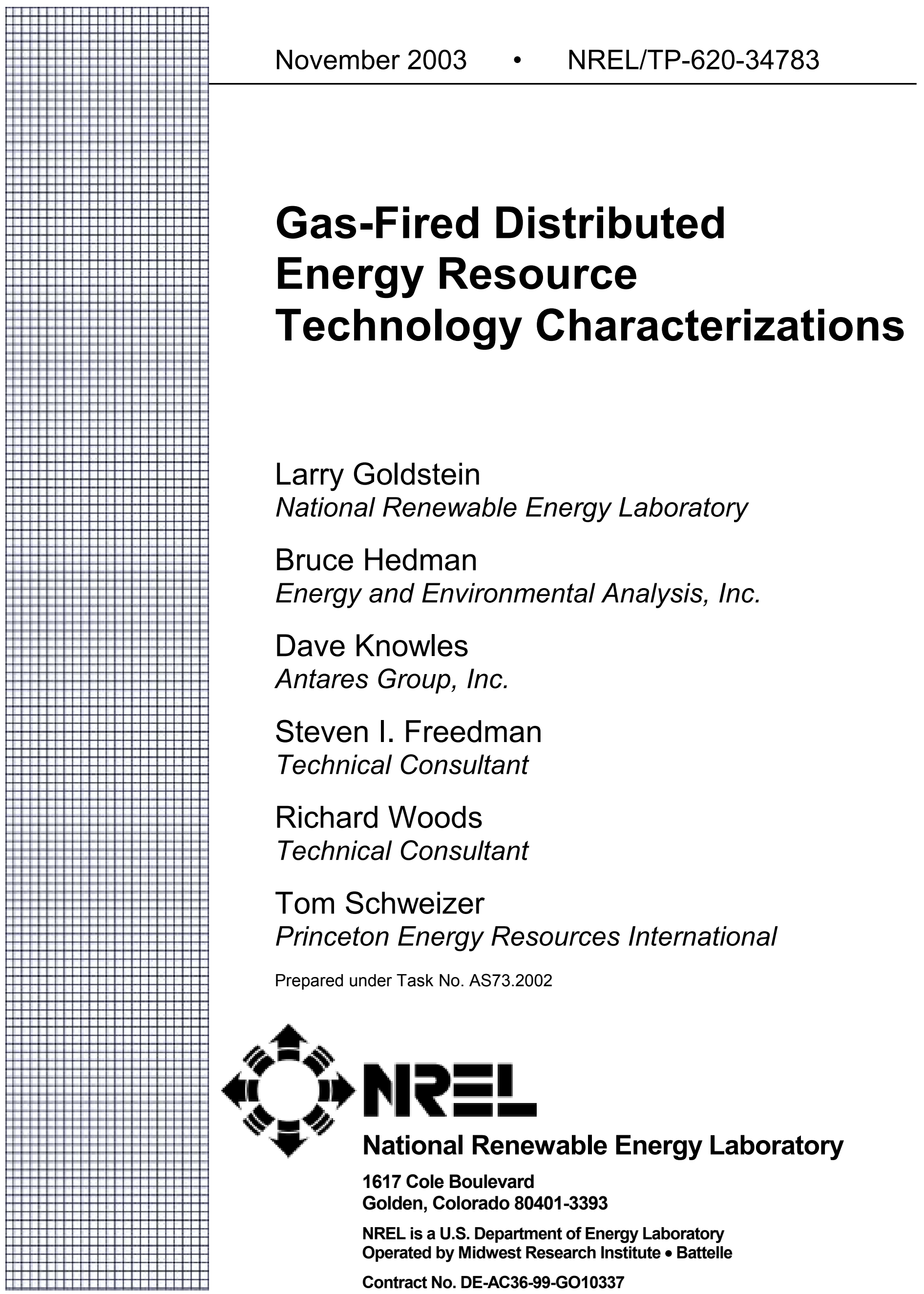




\section{NOTICE}

This report was prepared as an account of work sponsored by an agency of the United States government. Neither the United States government nor any agency thereof, nor any of their employees, makes any warranty, express or implied, or assumes any legal liability or responsibility for the accuracy, completeness, or usefulness of any information, apparatus, product, or process disclosed, or represents that its use would not infringe privately owned rights. Reference herein to any specific commercial product, process, or service by trade name, trademark, manufacturer, or otherwise does not necessarily constitute or imply its endorsement, recommendation, or favoring by the United States government or any agency thereof. The views and opinions of authors expressed herein do not necessarily state or reflect those of the United States government or any agency thereof.

Available electronically at http://www.osti.gov/bridge

Available for a processing fee to U.S. Department of Energy and its contractors, in paper, from:

U.S. Department of Energy

Office of Scientific and Technical Information

P.O. Box 62

Oak Ridge, TN 37831-0062

phone: 865.576.8401

fax: 865.576.5728

email: reports@adonis.osti.gov

Available for sale to the public, in paper, from:

U.S. Department of Commerce

National Technical Information Service

5285 Port Royal Road

Springfield, VA 22161

phone: 800.553.6847

fax: 703.605.6900

email: orders@ntis.fedworld.gov

online ordering: http://www.ntis.gov/ordering.htm 


\section{Acknowledgments}

This first edition of Gas-Fired Distributed Energy Resource Technology Characterizations was prepared through a collaboration of the National Renewable Energy Laboratory (NREL), the Department of Energy (DOE) Office of Energy Efficiency and Renewable Energy (EERE) and the Gas Research Institute (GRI). Overall project management for this multiyear effort was provided by Larry Goldstein (Energy Analysis Office, NREL) with funding support from Susan Holte (DOE EERE). Contributions were made by the following authors:

\section{Introduction and Overview}

Larry Goldstein, National Renewable Energy Laboratory Bruce Hedman, Energy and Environmental Analysis, Inc.

Dave Knowles, Antares Group, Inc.

\section{Reciprocating Engines}

Bruce Hedman, Energy and Environmental Analysis, Inc.

Dave Knowles, Antares Group, Inc.

\section{Small Gas Turbine Systems}

Bruce Hedman, Energy and Environmental Analysis, Inc.

Steven I. Freedman, Technical Consultant

Dave Knowles, Antares Group, Inc.

\section{Microturbine Systems}

Bruce Hedman, Energy and Environmental Analysis, Inc. Steven I. Freedman, Technical Consultant

Dave Knowles, Antares Group, Inc.

\section{Fuel Cell Systems}

Bruce Hedman, Energy and Environmental Analysis, Inc.

Richard Woods, Technical Consultant

Dave Knowles, Antares Group, Inc.

\section{Small Steam Turbine Systems}

Bruce Hedman, Energy and Environmental Analysis, Inc. Steven I. Freedman, Technical Consultant

Dave Knowles, Antares Group, Inc.

\section{Stirling Engine Systems}

Dave Knowles, Antares Group, Inc.

Bruce Hedman, Energy and Environmental Analysis, Inc.

Financial Evaluations

Tom Schweizer, Princeton Energy Resources International 
The Gas Research Institute assigned the Gas Technology Institute (GTI) responsibility for a major collaborative role in developing and shaping this report. Critical review of draft material and contributions to the report content were provided by the following GTI staff, managed by Director John Kelly, Distributed Energy Resources:

Reciprocating Engines: Kevin Olsen, Todd Kollross, and William Staats.

Small Gas Turbines: Kevin Olsen, Todd Kollross, Greg Rouse, and William Staats. Microturbines: Kevin Olsen, Todd Kollross, Greg Rouse, William Staats, and Richard Sweetser (EXERGY Partners Corp.).

Fuel Cells: Mark Richards, Robert Remick, Leonard Marianowski, Charles Berry, and William Staats.

Small Steam Turbines: Greg Rouse and William Staats. Stirling Engines: William Staats.

In addition to the named reviewers above, the project manager and authors wish to thank and acknowledge the contributions of the numerous invited peer reviewers that participated in an Internet-based review of the six technology characterizations and the individuals that attended the technical workshop and provided additional comment and review. Also, we would like to recognize Princeton Energy Resources International's Tom Schweizer and John Rezaiyan for their added critical review of all the technology characterization drafts and DOE EERE's Debbie Haught and Pat Hoffman for their many recommendations and contributions during the various stages of document development and peer review.

Document preparation and editing, as well as critical technical review, were performed by staff at NREL, including Larry Goldstein, Bill Babiuch, and Eldon Boes of the Energy Analysis Office; and Michelle Kubik of Communications. 


\section{Table of Contents}

Acknowledgments $\quad$ i

List of Figures $\quad$ vii

List of Tables $\quad$ viii

1. Introduction and Overview $1-1$

1.1 Project Background $1-1$

1.2 Technology Characterization Approach $1-1$

1.3 DER Power-Generation Applications $\quad 1-2$

1.4 Gas-Fired DER Applications and Markets $\quad 1-5$

1.5 Technology Overview $1-5$

1.5 Document Overview $1-9$

2. Reciprocating Engines $\quad 2-1$

1.0 Overview $2-1$

2.0 Applications $2-2$

2.1 Power-Only 2-3

2.2 Combined Heat and Power 2-4

3.0 Technology Description $\quad 2-6$

3.1 Basic Process and Components 2-6

3.2 Types of Reciprocating Engines $2-7$

$\begin{array}{lll}3.3 & \text { Design Characteristics } & 2-12\end{array}$

$\begin{array}{lr}\text { 4.0 Cost and Performance Characteristics } & 2-13\end{array}$

4.1 System Performance 2-13

4.2 Combined Heat and Power Performance 2-16

4.3 Performance and Efficiency Enhancements 2-18

$\begin{array}{lll}4.4 & \text { Capital Cost } & 2-18\end{array}$

$\begin{array}{ll}4.5 & \text { Maintenance } 2-21\end{array}$

$\begin{array}{llr}4.6 & \text { Fuels } & 2-22\end{array}$

$\begin{array}{ll}4.7 \quad \text { Availability and Life } & 2-25\end{array}$

$\begin{array}{lr}5.0 \text { Emission Characteristics } & 2-26\end{array}$

$\begin{array}{lll}5.1 & \text { Control Options } & 2-26\end{array}$

$\begin{array}{ll}5.2 & \text { System Emissions }\end{array}$

6.0 Key Technology Objectives $2-31$

7.0 Advanced Technology Projections $2-34$

8.0 References $2-41$

3. Small Gas Turbine Systems $\quad$ 3-1

1.0 Overview $3-1$

2.0 Applications $3-2$

2.1 Power-Only 3-2

2.2 Combined Heat and Power 3-3

3.0 Technology Description 3-5

3.1 Basic Process and Components $3-5$

3.2 Types of Gas Turbines $3-6$

3.3 Design Characteristics 3-6

$\begin{array}{lr}\text { 4.0 Cost and Performance Characteristics } & 3-7\end{array}$

4.1 System Performance $3-8$

4.2 Combined Heat and Power Performance 3-13

Gas-Fired Distributed Energy Resource Technology Characterizations

November 2003 - Page iii 
4.3 Performance and Efficiency Enhancements $\quad 3-15$

$\begin{array}{rrr}4.4 & \text { Capital Cost } & 3-16\end{array}$

$\begin{array}{rr}4.5 & 3-20\end{array}$

4.6 Fuels 3-21

4.7 Availability and Life $\quad 3-22$

$\begin{array}{lr}5.0 \text { Emission Characteristics } & 3-22\end{array}$

5.1 Control Options $3-23$

5.2 System Emissions $\quad 3-26$

$\begin{array}{lr}\text { 6.0 Key Technology Objectives } & 3-27\end{array}$

7.0 Advanced Technology Projections $3-32$

$\begin{array}{lr}8.0 \text { References } & 3-39\end{array}$

4. Microturbine Systems 4 4-1

1.0 Overview $4-1$

2.0 Applications $4-1$

2.1 Power-Only 4-2

2.2 Combined Heat and Power 4-3

3.0 Technology Description 4-4

3.1 Basic Process and Components 4-4

3.2 Types of Microturbines 4-4

3.3 Design Characteristics 4-8

4.0 Cost and Performance Characteristics 4-9

4.1 System Performance 4-9

4.2 Combined Heat and Power Performance 4-17

4.3 Performance and Efficiency Enhancements 4-18

4.4 Capital Cost 4-20

4.5 Maintenance 4-23

4.6 Fuels 4-24

$\begin{array}{lll}4.7 & \text { Availability and Life } & 4-25\end{array}$

5.0 Emission Characteristics $\quad 4-25$

5.1 Control Options $4-25$

5.2 System Emissions $\quad$ 4-27

6.0 Key Technology Objectives $\quad 4-27$

7.0 Advanced Technology Projections $\quad 4-31$

8.0 References $\quad 4-40$

5. Fuel Cell Systems

1.0 Overview $\quad 5-1$

2.0 Applications $\quad 5-2$

2.1 Power-Only 5-3

2.2 Combined Heat and Power 5-4

3.0 Technology Description $\quad 5-4$

3.1 Basic Process and Components 5-5

3.2 Types of Fuel Cells $5-9$

3.3 Design Characteristics $\quad$ 5-12

4.0 Cost and Performance Characteristics 5-13

4.1 System Performance 5-13

4.2 Combined Heat and Power Performance 5-18

4.3 Performance and Efficiency Enhancements 5-19

4.4 Capital Cost 5-19

4.5 Maintenance 5-21

Gas-Fired Distributed Energy Resource Technology Characterizations November 2003 - Page iv 
$\begin{array}{llr}4.6 & \text { Fuels } & 5-23\end{array}$

4.7 Availability and Life $\quad 5-23$

5.0 Emission Characteristics $\quad 5-24$

5.1 Control Options $\quad 5-24$

5.2 System Emissions $\quad$ 5-24

6.0 Key Technology Objectives $\quad 5-25$

7.0 Advanced Technology Projections $\quad$ 5-28

$\begin{array}{lr}8.0 \text { References } & 5-37\end{array}$

6. Small Steam Turbine Systems $\quad 6-1$

1.0 Overview $6-1$

2.0 Applications

2.1 Power-Only 6-2

2.2 Combined Heat and Power 6-2

3.0 Technology Description 6-4

3.1 Basic Process and Components 6-4

3.2 Types of Steam Turbines 6-6

3.3 Design Characteristics 6-8

4.0 Cost and Performance Characteristics 6-9

4.1 System Performance 6-9

4.2 Combined Heat and Power Performance 6-11

4.3 Performance and Efficiency Enhancements 6-11

4.4 Capital Cost 6-12

4.5 Maintenance 6-13

4.6 Fuels 6-13

4.7 Availability and Life 6-13

5.0 Emission Characteristics $\quad 6-14$

5.1 Control Options 6-14

5.2 System Emissions 6-16

6.0 Key Technology Objectives

7.0 Advanced Technology Projections $\quad 6-17$

7. Financial Evaluations $\quad$ 7-1

1.1 Introduction $\quad 7-1$

1.2 Calculation of Levelized Cost of Energy $\quad 7-1$

1.3 Gas Price Assumptions $\quad$ 7-2

1.4 Overview of Results

1.5 Calculation of COE with Constant Gas Prices 7-3

8. Appendix - Stirling Engine Systems

1.0 Overview $\quad 8-1$

2.0 Applications $\quad 8-2$

2.1 Power-Only 8-2

2.2 Combined Heat and Power 8-3

3.0 Technology Description $\quad 8-3$

3.1 Basic Process and Components 8-3

3.2 Types of Stirling Engines $\quad 8-6$

3.3 Design Characteristics $\quad 8-7$

4.0 Cost and Performance Characteristics $\quad 8-8$

$\begin{array}{llr}4.1 & \text { System Performance } & 8-10\end{array}$

4.2 Combined Heat and Power Performance 8-10

Gas-Fired Distributed Energy Resource Technology Characterizations

November 2003 - Page v 
$\begin{array}{llr}\text { 4.3 Performance and Efficiency Enhancements } & 8-10\end{array}$

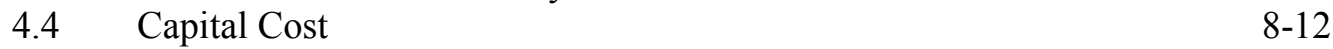

$\begin{array}{llr}4.5 & \text { Maintenance } & 8-13\end{array}$

$\begin{array}{llr}4.6 & \text { Fuels } & 8-14\end{array}$

4.7 Availability and Life 8-14

$\begin{array}{lr}5.0 \text { Emission Characteristics } & 8-15\end{array}$

$\begin{array}{lll}5.1 & \text { Control Options } & 8-15\end{array}$

5.2 System Emissions $\quad$ 8-15

\begin{tabular}{lr} 
6.0 Key Technology Objectives & $8-15$ \\
\hline
\end{tabular}

7.0 Advanced Technology Projections $\quad 8-16$ 


\section{List of Figures}

\section{Reciprocating Engines}

Figure 1: Existing Reciprocating Engine CHP - 801 MW at 1,055 sites

Figure 2: Part-Load Efficiency Performance (Spark-Ignition Engines)

Figure 3: Closed-Loop Heat-Recovery System

\section{Small Gas Turbine Systems}

Figure 1: Existing Simple-Cycle Gas Turbine CHP - 9,854 MW at 359 sites

Figure 2: Components of a Simple-Cycle Gas Turbine 3-5

Figure 3: Part-Load Power Performance $\quad 3-11$

Figure 4: Ambient Temperature Effects on Performance $\quad 3-12$

Figure 5: Altitude Effects on Power Output $\quad 3-12$

Figure 6: Heat Recovery from a Gas Turbine $3-13$

Figure 7: Effect of HRSG Stack Temperature on Total CHP Efficiency 3-14

Figure 8: Turbine Generator Package Costs by Size 3-17

4. Microturbine Systems

Figure 1: Microturbine-Based CHP System (Single-Shaft Design) 4-5

Figure 2: Typical Microturbine Efficiency as a Function of Compressor Pressure Ratio and Turbine Inlet Temperature

Figure 3: Microturbine Specific Power as a Function of Compressor Pressure Ratio and Turbine Inlet Temperature 4-14

Figure 4: Microturbine Part-Load Efficiency 4-15

Figure 5: Ambient Temperature Effects on Microturbine Performance 4-16

Figure 6: Altitude Effects on Microturbine Power Output 4-17

Figure 7: Microturbine Efficiency as a Function of Recuperator Effectiveness 4-19

Figure 8: Efficiency Comparison of Microturbines w/ Metallic and Ceramic Turbines 4-29

Figure 9: Specific Power Comparison of Microturbines w/ Metallic and Ceramic Turbines 4 4-29

\section{Fuel Cell Systems}

Figure 1: Fuel Cell Electrochemical Process $\quad$ 5-5

Figure 2: Effect of Operating Temperature on Fuel Cell Efficiency 5-7

Figure 3: Part-Load Efficiency Performance $\quad$ 5-18

6. Small Steam Turbine Systems

Figure 1: Existing Boiler/Steam Turbine CHP Capacity by Industry - 19,062 MW/582 sites 6-3

Figure 2: Existing Boiler/Steam Turbine CHP Capacity by Boiler Fuel Type -

$$
\text { 19,062 MW/582 sites }
$$

Figure 3: Components of a Boiler/Steam Turbine System $\quad 6-5$

Figure 4: Noncondensing (Back-Pressure) Steam Turbine 6-6

Figure 5: Extraction Steam Turbine $\quad$ 6-7

8. Appendix - Sitrling Engine Systems $\quad 8-1$

Figure 1: Stirling Engine Fundamentals $\quad$ 8-3

Figure 2: Carnot Cycle Compared to the Stirling Engine $\quad 8-4$

Figure 3: STM 4-120 PowerUnit Pacaged DG System $\quad 8-5$

Figure 4: STM 4-120 Kinematic Stirling Engine Core $\quad 8-6$

Figure 5: Stirling Engine Efficiency $\quad$ 8-11

Figure 6: Environmental Performance at Part-Load Conditions $\quad 8-11$ 


\section{List of Tables}

1. Introduction and Overview $1-1$

Table 1: Applications and Markets for Gas-fired DG Technologies $\quad$ 1-5

Table 2: Comparison of DG Technologies $\quad 1-8$

2. Reciprocating Engines $\quad$ 2-1

Table 1: Reciprocating Engine Types by Speed (Available MW Ratings) 2-11

Table 2: Reciprocating Engine Systems - Typical Performance Parameters (2003) 2-14

Table 3: Estimated Capital Cost for Typical Reciprocating Engine-Generators in Grid-Interconnected Power-Only Applications (2003) 2-20

Table 4: Estimated Capital Cost for Typical Reciprocating Engine-Generators in $\begin{array}{ll}\text { Grid-Interconnected CHP Applications (2003) 2-21 } & \text { 2-22 }\end{array}$

Table 5: Representative Overhaul Intervals for Reciprocating Engines in Base-load Service 2-22

Table 6: Typical Natural Gas-Fuel Reciprocating Engine O\&M Costs 2-22

Table 7: Major Constituents of Gaseous Fuels $\quad$ 2-24

Table 8: Representative $\mathrm{NO}_{\mathrm{x}}$ Emissions from Reciprocating Engines $\begin{array}{ll}\text { (Without Add-on Controls) } & 2-26\end{array}$

Table 9: NOx Emissions versus Efficiency Tradeoff Example 2-28

Table 10: Reciprocating Engine Emissions Characteristics $\begin{array}{lr}\text { (Without Exhaust-Control Options) } & 2-30\end{array}$

Table 11: Current and Advanced Reciprocating Engine System Characteristics 2-36

3. Small Gas Turbine Systems $\quad$ 3-1

Table 1: Gas Turbine Systems - Typical Performance Parameters 3-9

Table 2: Power Requirements for Natural Gas Compression 3-10

Table 3: Estimated Capital Cost for Typical Gas Turbine Systems in
Grid-Interconnected CHP Applications (2003)

$\begin{array}{ll}\text { Table 4: } & \text { Estimated Capital Cost for Typical Gas Turbine Systems in } \\ & \text { Grid-Interconnected Power-Only Applications (2003) }\end{array}$

Table 5: Typical Gas Turbine (Non-fuel) O\&M Costs (2003) 3-20

Table 6: Gas Turbine Emission Characteristics (Without Exhaust-Control Options) 3-27

Table 7: Current and Advanced Combustion Turbine Characteristics 3-35

4. Microturbine Systems

Table 1: Microturbine Systems - Typical Performance Parameters 4-11

Table 2: Estimated Capital Cost for Typical Microturbine Generator Systems in
Grid-Interconnected CHP Applications (2003)

Table 3: Estimated Capital Cost for Typical Microturbine Generator Systems in Grid-Interconnected Power-Only Applications (2003) 4-23

Table 4: Microturbine Emission Characteristics $\quad$ 4-27

Table 5: Projected Microturbine Evolution Through 2030

Table 6: Current and Advanced Microturbine System Characteristics 4-35

5. Fuel Cell Systems

Table 1: Characteristics of Major Fuel Cell Types $\quad 5-10$

Table 2: Fuel Cell Systems - Typical Performance Parameters (2003) 5-15

Table 3: Estimated Capital Cost for Typical Fuel Cell Systems in Grid-Interconnected CHP Applications (2003 \$/kW) 5-21

Table 4: Typical Fuel Cell Systems (Non-fuel) O\&M Costs (2003) 5-22 
Table 5: Fuel Cell Emission Characteristics (without Additional Controls)

Table 6: Projected Fuel Cell Evolution Through 2030

Table 7: Current and Advanced Fuel Cell System Characteristics

6. Small Steam Turbine Systems

Table 1: Boiler/Steam Turbine Systems - Typical Performance Parameters (2003)

Table 2: Typical Boiler Emissions Ranges

Table 3: Current and Advanced Steam Turbine System Characteristics

7. Financial Evaluations

Table 1: Example Calculation of Levelized COE (for 70kW Microturbines)

Table 2: Delivered Industrial Gas Prices Used in Cost of Energy Estimates

Table 3: Cost of Energy Trends for Selected Distributed Gas Technologies in CHP Applications

Table 4: Cost of Energy Trends for Distributed Technologies

Table 5: Cost of Energy Trends for Selected Distributed Technologies, Assuming Constant Gas Prices

8. Appendix - Stirling Engine Systems

Table 2: Estimated Capital Cost for Stirling Engine in Grid-Parallel CHP Applications (2003)

Table 3: Stirling Engine Emission Characteristics

Table 4: Projected Stirling Evolution Through 2030

Table 5: Current and Advanced Stirlineg Engine CHP System Characteristics 


\section{Introduction and Overview}

\subsection{Project Background}

The U. S. Department of Energy (DOE) Office of Energy Efficiency and Renewable Energy (EERE) is directing substantial programs in the development and encouragement of new energy technologies. Among them are renewable energy and distributed energy resource technologies. As part of its ongoing effort to document the status and potential of these technologies, DOE EERE directed the National Renewable Energy Laboratory to lead an effort to develop and publish Distributed Energy Technology Characterizations (TCs) that would provide both the department and energy community with a consistent and objective set of cost and performance data in prospective electric-power generation applications in the United States. Toward that goal, DOE/EERE - joined by the Electric Power Research Institute (EPRI) - published the Renewable Energy Technology Characterizations in December 1997.

As a follow-up, DOE EERE - joined by the Gas Research Institute - is now publishing this document, Gas-Fired Distributed Energy Resource Technology Characterizations. The Gas Research Institute (GRI) has long had a considerable program of R\&D aimed at developing commercially viable natural-gas-fired distributed generation systems and transitioning them to commercial partners. Because of this R\&D, DOE invited GRI to collaborate on this report, and GRI designated its primary contractor, the Gas Technology Institute, as technical reviewer of the technology characterization chapters.

This report describes the current status and future potential of six natural gas-fired distributed energy resource technologies through the year 2030. The six DER power technologies are:

- Reciprocating engines

- Small industrial gas turbines (1 MW to $40 \mathrm{MW})$

- Microturbines

- Small steam turbines

- Fuel Cells

- Stirling engines

While these technologies are capable of utilizing a variety of fuels in a range of applications, the focus for these characterizations are in electric power and combined heat and power (CHP) applications using natural gas.

\subsection{Technology Characterization Approach}

A three-step approach was used to develop the TCs. In the first step, the best available information was compiled by the authors, based on their knowledge and experience from years of direct involvement in distributed energy, and then reviewed by experts to produce a set of six draft distributed energy TCs. The next step involved extensive peer review of the TCs data. An initial peer review was conducted over the Internet using a password-protected Web site during a three-month period. Invited participants were asked to provide detailed review of one or several TCs based on their areas of expertise. Reviewers included technology manufacturers, equipment 
packagers, component manufacturers, end users, industry associations, researchers, and independent consultants. After the Internet peer review, the TCs were revised to reflect the comments received. In the third step, the revised TCs were then used as a basis for detailed discussions in a series of small, follow-up technical workshops organized by NREL, which involved the TC authors and selected outside reviewers. The workshops focused on three areas of the TC: the current status of the technology, the key technology objectives, and the cost and performance expectations for the technology. The resulting discussions were then used to again modify the TCs providing a consensus viewpoint.

\subsection{DER Power-Generation Applications}

DER power-generating systems range in size and capacity from a few kilowatts up to $50 \mathrm{MW}$. They comprise a portfolio of technologies that can be located at or near the location where the energy is used. DER technologies provide opportunities for greater local control of electricity delivery and consumption. They also enable more efficient utilization of waste heat in combined heat and power (CHP) applications - boosting efficiency and lowering emissions. CHP systems provide electricity, hot water, heat for industrial processes, space heating and cooling, refrigeration, and humidity control to improve indoor air quality and comfort. DER technologies are playing an increasingly important role in the nation's energy portfolio, providing a portion or all of the power needs to a wide variety of users. There are many different potential applications including base-load power, peaking power where on-site generation is used to reduce the demand charges imposed by the electric utility, back-up power, remote power, power quality, and CHP, providing both electricity and thermal needs to the site. Usually, customers own the small-scale, on-site power generators, or they may be owned and operated by a third party.

The following is a list of potential distributed generation applications that are amenable to the natural gas-fired distributed generation (DG) technologies characterized in this document.

\section{Power-Only Applications}

\section{Backup Power}

Backup or standby power systems are required by fire and safety codes for such applications as hospitals, elevators, and water pumping. Backup power also is an economic choice for customers with high forced outage costs such as telecommunications, retail, and certain process industries. The backup power system is typically the simplest distributed generation system, providing power only when the primary source is out of service or falters in its voltage or frequency. DG technology characteristics important for backup power include:
- $\quad$ Low capital costs
- $\quad$ Black start capability
- $\quad$ High reliability
- $\quad$ Low fixed maintenance costs

Because of the relatively low number of operating hours required for backup power applications, efficiency, emissions, and variable maintenance costs are not usually major factors in technology selection. 


\section{Base-load/Remote Power}

Continuous on-site power generation without heat recovery can be a cost-effective option for commercial and industrial applications in high electric price areas or in specialized situations, such as remote sites or availability of low cost (or no cost) waste fuels. Important DG technology characteristics for base-load power-only include:

- $\quad$ High electric efficiency

- $\quad$ Low maintenance costs (variable)

- $\quad$ Low emissions (depending on location)

- $\quad$ High reliability

- $\quad$ Multi-fuel capability

\section{Demand Response Peaking}

On-site generating systems can be used in coordinated peak-shaving programs with servicing utilities. Under such arrangements, the utility offers capacity and/or commodity payments for very limited hours of use. These programs typically require as few as 50 hours/year to as many as 400 hours/year. Important DG technology characteristics for demand response programs include:

- Low installed cost

- Low maintenance costs (fixed)

- Quick startup

\section{Customer Peaking}

Customer-driven peak shaving can be used to reduce utility demand charges, defer retail electricity purchases during high-price periods, or to secure more competitive power contracts from energy service providers by smoothing site demand or by allowing interruptible service. Operating hours for customer-driven peaking are usually between 200 to 3,000 hours a year. Important DG technology characteristics for peaking power applications include:

- Low installed cost

- Low maintenance costs (fixed)

- Quick startup

- High electric efficiency (important for systems with operating hours in the higher end of the range)

\section{Premium Power}

Premium power is an emerging market for distributed generation systems. These systems either provide high-quality power to sensitive-load customers at a higher level of reliability and/or higher power quality than is typically available from the grid. Such systems also may serve to clean up negative effects that the customer's own load may have on power quality for neighboring customers. The growing use of sensitive electronic equipment is making control of power quality much more important in today's market. Current DG premium power approaches 
employ on-site generation as the primary power source and the grid as back-up (as compared to emergency or standby generation). Important DG technology characteristics for active premium power applications include:

- High efficiency

- Low maintenance costs

- High reliability

- Clean power output

- Low emissions

\section{Utility-Based Grid Support}

Distributed generation can be used by an electric utility to provide ancillary services at the transmission and distribution (T\&D) level, or to replace or defer T\&D investments. The market for ancillary services is still unfolding, but services that distributed generation could provide include spinning reserves, voltage and frequency support to enhance local area reliability and power quality, and reactive power control. The critical DG technology characteristics vary, depending on applications, but often include:

- Low installed cost

- Low maintenance costs (fixed)

- High reliability

\section{Combined Heat and Power Applications}

\section{Combined Heat and Power}

End users with significant thermal and power needs can generate both thermal and electrical energy in a single combined heat and power system located at or near the facility. CHP, also called cogeneration, can substantially increase the efficiency of energy utilization, resulting in lower operating costs for the user and potential reductions in emissions of criteria pollutants and $\mathrm{CO}_{2}$. Heat can generally be recovered in the form of hot water or steam, or the hot exhaust from the system can be used directly for applications such as process heating or drying (e.g., grain drying, brick drying or greenhouses). The waste heat also can be used to drive thermally activated equipment, such as absorption chillers for cooling or desiccant wheel regeneration for dehumidification. Annual operating hours for CHP systems are typically 6,000 or more. Important DG technology characteristics for CHP include:

- High useable thermal output (resulting in high overall efficiency)

- Low maintenance costs (variable)

- Low emissions

- High reliability

CHP has been traditionally applied by larger industrial users with high steam and power demands (chemicals, paper, refining) and by smaller, institutional applications (universities, hospitals). A large potential also exists for smaller CHP systems in light industrial and commercial applications. 


\subsection{Gas-Fired DER Applications and Markets}

The distributed generation technologies characterized in this document can meet the needs of a wide range of users in the applications described above in the residential, commercial, and industrial sectors. Decision makers at all levels need to be aware of the comparative performance and costs of each technology option, as well as the applications where they are best suited. The following table summarizes the applicability of the DG technologies profiled in this document to the major applications and markets:

Table 1. Applications and Markets for Gas-fired DG Technologies

\begin{tabular}{|l|c|c|c|c|c|c|c|l|}
\hline $\begin{array}{l}\text { DG } \\
\text { Technologies }\end{array}$ & $\begin{array}{c}\text { Standby } \\
\text { Power }\end{array}$ & $\begin{array}{c}\text { Baseload } \\
\text { Power } \\
\text { Only }\end{array}$ & $\begin{array}{c}\text { Demand } \\
\text { Response } \\
\text { Peaking }\end{array}$ & $\begin{array}{c}\text { Customer } \\
\text { Peak } \\
\text { Shaving }\end{array}$ & $\begin{array}{c}\text { Premium } \\
\text { Power }\end{array}$ & $\begin{array}{c}\text { Utility } \\
\text { Grid } \\
\text { Support }\end{array}$ & $\begin{array}{c}\text { Combined } \\
\text { Heat and } \\
\text { Power }\end{array}$ & $\begin{array}{l}\text { Applicable Market } \\
\text { Sectors }\end{array}$ \\
\hline $\begin{array}{l}\text { Reciprocating } \\
\text { Engines } \\
\text { (50 kW to 5 } \\
\text { MW) }\end{array}$ & $\times$ & $\times$ & $\times$ & $\times$ & $\times$ & $\times$ & $\times$ & $\begin{array}{l}\text { Commercial } \\
\text { Buildings, Light } \\
\text { Industrial, Utility } \\
\text { Grid (larger units), } \\
\text { Waste Fuels }\end{array}$ \\
\hline $\begin{array}{l}\text { Gas Turbines } \\
\text { (500 kW to 50 } \\
\text { MW) }\end{array}$ & $\times$ & $\times$ & $\times$ & $\times$ & $\times$ & $\times$ & $\begin{array}{l}\text { Large Commercial, } \\
\text { Institutional, } \\
\text { Industrial, Utility } \\
\text { Grid, Waste Fuels }\end{array}$ \\
\hline $\begin{array}{l}\text { Steam } \\
\text { Turbines } \\
\mathbf{5 0 0} \text { kW to } \\
\mathbf{1 0 0} \text { MW) }\end{array}$ & $\times$ & $\times$ & $\times$ & $\times$ & $\times$ & $\times$ & $\begin{array}{l}\text { Institutional } \\
\text { Buildings/Campuses, } \\
\text { Industrial, Waste } \\
\text { Fuels }\end{array}$ \\
\hline $\begin{array}{l}\text { Microturbines } \\
\mathbf{( 3 0} \text { kW to 250 } \\
\text { kW) }\end{array}$ & $\times$ & $\times$ & $\times$ & $\begin{array}{l}\text { Commercial } \\
\text { Buildings, Light } \\
\text { Industrial, Waste } \\
\text { Fuels }\end{array}$ \\
\hline $\begin{array}{l}\text { Fuel Cells } \\
\mathbf{( 5} \text { kW to 2 } \\
\text { MW) }\end{array}$ & & $\times$ & & & $\times$ & $\times$ & $\times$ & $\begin{array}{l}\text { Residential, } \\
\text { Commercial, Light } \\
\text { Industrial }\end{array}$ \\
\hline
\end{tabular}

\subsection{Technology Overview}

While each of the characterized technologies is discussed in detail in this document, the following provides an overview of their current status and applications.

\section{Reciprocating Engines}

Reciprocating internal combustion engines represent a widespread and mature technology for power generation. Reciprocating engines are used for all types of power generation, from small portable gensets to larger industrial engines that power generators of several megawatts. Spark ignition engines for power generation use natural gas as the preferred fuel - although they can be set up to run on propane or gasoline. Diesel-cycle, compression ignition engines operate on

\footnotetext{
${ }^{1}$ Thermal energy is in the form of steam from gas and steam turbines; the other characterized technologies produce thermal energy in the form of hot water or low-pressure steam.
} 
diesel fuel or heavy oil, or can be set up in a dual-fuel configuration that can burn primarily natural gas with a small amount of diesel pilot fuel. Reciprocating engines offer low first cost, easy start-up, proven reliability when properly maintained, and good load-following characteristics. Drawbacks of reciprocating engines include relatively high noise levels, relatively high air emissions, and the need for regular maintenance. The emissions profiles of reciprocating engines have been improved significantly in recent years by the use of exhaust catalysts and through better design and control of the combustion process. Gas-fired reciprocating engines are well suited for packaged CHP in commercial and light industrial applications of less than $5 \mathrm{MW}$. Smaller engine systems produce hot water. Larger systems can be designed to produce low-pressure steam.

\section{Gas Turbines}

Gas turbines for distributed generation applications are an established technology in sizes from several hundred kilowatts up to about $50 \mathrm{MW}$. Gas turbines produce high-quality heat that can be used to generate steam for on-site use or for additional power generation (combined-cycle configuration). Gas turbines can be set up to burn natural gas, a variety of petroleum fuels or can have a dual-fuel configuration. Gas turbine emissions can be controlled to very low levels using water or steam injection, advanced dry combustion techniques, or exhaust treatment such as selective catalytic reduction (SCR). Maintenance costs per unit of power output are among the lowest of DG technology options. Low maintenance and high-quality waste heat make gas turbines an excellent match for industrial or commercial CHP applications larger than $5 \mathrm{MW}$. Technical and economic improvements in small turbine technology are pushing the economic range into smaller sizes as well.

An important advantage of CHP using gas turbines is the high-quality waste heat available in the exhaust gas. The high-temperature exhaust gas is suitable for generating high-pressure steam, making gas turbines a preferred CHP technology for many industrial processes. In simple cycle gas turbines, hot exhaust gas can be used directly in a process or by adding a heat-recovery steam generator (HRSG) that uses the exhaust heat to generate steam or hot water. Because gas turbine exhaust is oxygen-rich, it can support additional combustion through supplementary firing. A duct burner can be fitted within the HRSG to increase the steam production at lower-heatingvalue efficiencies of $90 \%$ and greater.

\section{Steam Turbines}

Steam turbines convert steam energy into shaft power and are one of the most versatile and oldest prime mover technologies used to drive generators or mechanical machinery. The capacity of steam turbines can range from fractional horsepower to several hundred MW for large utility power plants. A steam turbine is captive to a separate heat source and does not directly convert a fuel source to electric energy. Steam turbines require a source of high-pressure steam that is produced in a boiler or heat recovery steam generator (HRSG). Boiler fuels can include fossil fuels such as coal, oil, or natural gas or renewable fuels like wood or municipal waste. Most of the electricity in the United States is generated by conventional steam turbine power plants. Steam turbine CHP systems are primarily used in industrial processes where solid or waste fuels are readily available for boiler use. In CHP applications, steam is extracted from 
the steam turbine and used directly in a process or for district heating, or it can be converted to other forms of thermal energy including hot water or chilled water.

\section{Microturbines}

Microturbines are very small combustion turbines that are currently offered in a size range of 30 $\mathrm{kW}$ to $250 \mathrm{~kW}$. Microturbine technology has evolved from the technology used in automotive and truck turbochargers and auxiliary power units for airplanes and tanks. Several companies have developed commercial microturbine products and are in the early stages of market entry. A number of other competitors are developing systems and planning to enter the market within the next few years. In the typical configuration, the turbine shaft, spinning at up to $100,000 \mathrm{rpm}$, drives a high-speed generator. The generator's high-frequency output is converted to the $60 \mathrm{~Hz}$ power used in the United States by sophisticated power electronics controls. Electrical efficiencies of $23-26 \%$ are achieved by employing a recuperator that transfers heat energy from the exhaust stream back into the combustion air stream. Microturbines are compact and lightweight, with few moving parts. Many designs are air-cooled and some even use air bearings, thereby eliminating the cooling water and lube oil systems.

Low-emission combustion systems, which provide emissions performance approaching that of larger gas turbines, are being demonstrated. Microturbines' potential for low emissions, reduced maintenance, and simplicity promises to make on-site generation much more competitive in the 30 to $300 \mathrm{~kW}$ size range characterized by commercial buildings or light industrial applications. Microturbines for CHP duty are typically designed to recover hot water or low-pressure steam.

\section{Fuel Cells}

Fuel cells produce power electrochemically, more like batteries than conventional generating systems. Unlike storage batteries, however - which produce power from stored chemicals - fuel cells produce power when hydrogen fuel is delivered to the cathode of the cell, and oxygen in air is delivered to the anode. The resultant chemical reactions at each electrode create a stream of electrons (or direct current) in the electric circuit external to the cell. The hydrogen fuel can come from a variety of sources, but the most economic is steam reforming of natural gas - a chemical process that strips the hydrogen from both the fuel and the steam. Several different liquid and solid media that can be used inside fuel cells - phosphoric acid (PAFC), molten carbonate (MCFC), solid oxide (SOFC), and proton exchange membrane (PEMFC). Each of these media comprises a distinct fuel cell technology with its own performance characteristics and development schedule. PAFCs are in early commercial market development now, with 200 $\mathrm{kW}$ units delivered to more than 120 customers worldwide. The PEMFC and MCFC technologies are now in early market introduction and demonstration. SOFC units are in development and testing. Fuel cells promise higher efficiency than generation technologies based on heat engine prime movers. In addition, fuel cells are inherently quiet and extremely clean running. Similar to microturbines, fuel cells require power electronics to convert direct current to $60-\mathrm{Hz}$ alternating current. Many fuel cell technologies are modular and capable of application in small commercial and even residential markets; other technology operates at high temperatures in larger sized systems that would be well suited to industrial CHP applications. 
Table 2 summarizes the characteristics of each technology.

Table 2. Comparison of DG Technologies

\begin{tabular}{|c|c|c|c|c|c|}
\hline & Recip Engine & Gas Turbine & Steam Turbine & Microturbine & Fuel Cells \\
\hline Technology Status & Commercial & Commercial & Commercial & Early entry & $\begin{array}{l}\text { Early entry/ } \\
\text { development }\end{array}$ \\
\hline Size (MW) & $0.01-5$ & $0.5-50$ & $0.05-50$ & $0.03-0.25$ & $0.005-2$ \\
\hline Electric Efficiency $(\mathrm{HHV})^{2}$ & $30-37 \%$ & $22-37 \%$ & $5-15 \%$ & $23-26 \%$ & $30-46 \%$ \\
\hline Total CHP Efficiency $(\mathrm{HHV})^{3}$ & $69-78 \%$ & $65-72 \%$ & $80 \%$ & $61-67 \%$ & $65-72 \%$ \\
\hline $\begin{array}{l}\text { Power-Only installed cost } \\
(\$ / k W)^{4}\end{array}$ & $700-1,000$ & $600-1,400$ & $300-900^{5}$ & $1,500-2,300$ & $2,800-4,700$ \\
\hline CHP installed cost $(\$ / k W)^{3}$ & $900-1,400$ & $700-1,900$ & $300-900^{4}$ & $1,700-2,600$ & $3,200-5,500$ \\
\hline O\&M Cost (\$/kWh) & $0.008-0.018$ & $0.004-0.01$ & $<0.004$ & $0.013-0.02$ & 0.020 .04 \\
\hline Availability & $>96 \%$ & $>98 \%$ & Near $100 \%$ & $95 \%$ & $90 \%$ \\
\hline Equipment Life (years) & 20 & 20 & $>25$ & 10 & 10 \\
\hline Fuel pressure (psi) & $\begin{array}{l}\text { 1-65 (may } \\
\text { require fuel } \\
\text { compressor) }\end{array}$ & $\begin{array}{c}100-500 \text { (may } \\
\text { require fuel } \\
\text { compressor) }\end{array}$ & $\mathrm{n} / \mathrm{a}$ & $\begin{array}{l}55-90 \text { (may } \\
\text { require fuel } \\
\text { compressor) }\end{array}$ & $0.5-45$ \\
\hline Fuels & $\begin{array}{l}\text { natural gas, } \\
\text { biogas, liquid } \\
\text { fuels }\end{array}$ & $\begin{array}{c}\text { natural gas, } \\
\text { biogas, } \\
\text { distillate oil }\end{array}$ & all & $\begin{array}{l}\text { natural gas, } \\
\text { biogas }\end{array}$ & $\begin{array}{l}\text { hydrogen, } \\
\text { natural gas }\end{array}$ \\
\hline $\begin{array}{l}\mathrm{NO}_{\mathrm{x}} \text { Emissions } \\
(\mathrm{lb} / \mathrm{MWh})^{6}\end{array}$ & $0.2-6$ & $0.8-2.4$ & $\begin{array}{l}\text { Function of } \\
\text { boiler missions }\end{array}$ & $0.5-1.25$ & $<0.1$ \\
\hline Uses for Heat Recovery & $\begin{array}{l}\text { hot water, low } \\
\text { pressure } \\
\text { steam, district } \\
\text { heating }\end{array}$ & $\begin{array}{l}\text { direct heat, } \\
\text { hot water, LP- } \\
\text { HP steam, } \\
\text { district heating }\end{array}$ & $\begin{array}{l}\text { LP-HP steam, } \\
\text { district heating }\end{array}$ & $\begin{array}{l}\text { direct heat, hot } \\
\text { water, low } \\
\text { pressure steam }\end{array}$ & $\begin{array}{l}\text { hot water, low } \\
\text { pressure steam }\end{array}$ \\
\hline Thermal Output (Btu/kWh $)^{7}$ & $3,200-5,600$ & $3,200-6,800$ & $1,000-50,000$ & $4,500-6,500$ & $1,800-4,200$ \\
\hline
\end{tabular}

${ }^{2}$ Except where noted, the efficiencies quoted in this report are based on higher heating value (HHV), which includes the heat of condensation of the water vapor in the combustion products. In engineering and scientific literature, the lower heating value (LHV - which does not include the heat of condensation of the water vapor in the combustion products) is often used. The HHV is greater than the LHV by approximately $10 \%$ with natural gas as the fuel (i.e., $50 \%$ LHV efficiency is equivalent to $45 \%$ HHV efficiency). HHV efficiencies are about $8 \%$ greater than LHV efficiencies for oil (liquid petroleum products) and 5\% for coal. The report specifically indicates the few instances where it uses lower heating values.

${ }^{3}$ Total CHP Efficiency $=($ net electric power generated + net thermal energy recovered $) /$ total CHP system fuel input

${ }^{4}$ Total installed cost estimates for "typical" system installations. Commercially available system costs are based on published manufacturers' equipment costs to the end-user and estimated installation costs for a typical installation with minimal site preparation. Equipment costs for market entry systems are based on manufacturer market entry target prices and typical installation costs for similarly sized commercially available systems. Mature market costs would be expected to be lower.

${ }^{5}$ Steam turbine costs are based on installation of turbine systems only; boiler and steam systems costs are not included.

${ }^{6}$ Emissions are based on system-out emissions without exhaust gas cleanup.

${ }^{7}$ Thermal output is based on recoverable thermal energy available per kWh of power generated 


\subsection{Document Overview}

Five gas-fired distributed power system technologies (reciprocating engines, small industrial gas turbines, microturbines, small steam turbines and fuel cells) have been characterized in the five main chapters of this document. Also included in the appendix - as an example of an emerging technology first entering the initial stages of commercialization - is the Stirling engine technology characterization. All data for the Stirling engine TC was provided by its only current developer, STM POWER, INC.

Each technology characterization chapter has the following organization:

1.0 Overview (general discussion of the technology history and status).

2.0 Applications (power-only and CHP applications for the technology).

3.0 Technology Description (describes the basic operation and design characteristics of the technology).

4.0 Cost and Performance Characteristics (provides primary data tables on current system cost and performance).

5.0 Emission Characteristics (data tables on emissions and control options).

6.0 Key Technology Objectives (research and development pathways following a business-asusual approach).

7.0 Advanced Technology Projection (projected cost and performance parameters to 2030). As a cautionary note, the projected cost and performance data provided in Section 7 is not based on market studies. Engineering judgment has been used to estimate the size of the market for each technology.

Several technology characterizations also contain Section 8, which lists additional references and Web sites relating to the technology. However, this section is not included in every TC.

A financial chapter (Chapter 7) provides estimates of levelized cost of energy. 


\section{Reciprocating Engines}

\subsection{Overview}

Reciprocating internal combustion engines are a widespread and widely known technology. North American production exceeds 35 million units per year for automobiles, trucks, construction and mining equipment, marine propulsion, lawn care, and a diverse set of power generation applications. A variety of stationary engine products are available for a range of power-generation market applications and duty cycles, including standby and emergency power, peaking service, intermediate and base-load power, and combined heat and power (CHP). Reciprocating engines are available for electrical power generation applications using many different fuel sources in sizes ranging from a few kilowatts to more than $15 \mathrm{MW}$ in individual applications.

There are two basic types of reciprocating engines - spark ignition (SI) and compression ignition (CI). Spark ignition engines for power generation use natural gas as the preferred fuel, although they can be set up to run on propane, gasoline, or special gases such as landfill, flare, and digester gas. Compression ignition engines (often called diesel engines) operate on diesel fuel or heavy (residual) oil, or they can be set up to run in a dual-fuel configuration that burns primarily natural gas with a small amount of diesel pilot fuel for ignition.

Diesel engines have historically been the most popular type of reciprocating engine for both small and large power-generation applications. However, in the United States and other industrialized nations, diesel engines are increasingly restricted to emergency standby or limited duty-cycle service because of air emission concerns. As a result, the natural gas-fueled SI engine is now the engine of choice for the higher-duty-cycle stationary power market (more than 500 $\mathrm{hr} / \mathrm{yr}$ ) and is the primary focus of this report. Natural gas-fueled reciprocating engines are commercially available in sizes ranging from $10 \mathrm{~kW}$ to $7 \mathrm{MW}$.

Current generation natural gas engines offer low first-cost, fast start-up, proven reliability when properly maintained; excellent load-following characteristics, and significant heat-recovery potential. Electric efficiencies of natural gas engines range from $28 \% \mathrm{LHV}^{1}$ for stoichiometric engines $^{2}$ smaller than $100 \mathrm{~kW}$ to more than $40 \%$ LHV for larger lean-burn engines ${ }^{3}(>2 \mathrm{MW})$. Waste heat can be recovered from the engine exhaust and from the engine cooling systems to

\footnotetext{
${ }^{1}$ LHV stands for lower heating value. Most of the efficiencies quoted in this report are based on higher heating value (HHV) fuel consumption, which includes the heat of condensation of the water vapor in the combustion products. In engineering and scientific literature, the lower heating value (LHV), which does not include the heat of condensation of the water vapor in the combustion products, is often used. The HHV is greater than the LHV by approximately $10 \%$ with natural gas as the fuel (i.e., $50 \%$ LHV efficiency is equivalent to $45 \%$ HHV efficiency). HHV fuel consumption is about 6-8\% greater for oil (liquid petroleum products) and 5\% for coal.

${ }^{2}$ Stoichiometric engines are designed to burn the chemically correct proportions of fuel and air needed for complete combustion, i.e., there is no excess fuel or oxygen after combustion.

${ }^{3}$ In lean-burn engines, the fuel-air mixture contains more air than is needed for complete combustion. A rich-burn engine is a common term for a stoichiometric engine, where the air-to-fuel ration is maintained at or near the correct level for complete combustion.
} 
produce either hot water or low-pressure steam for CHP applications. Overall, CHP system efficiencies (electricity and useful thermal energy) of $70 \%$ to $80 \%$ are routinely achieved with natural gas-engine systems in applications with electrical and heat loads appropriately in balance.

Reciprocating engine technology has improved dramatically in the past three decades, driven by environmental and economic pressures for power density improvements (more output per unit of engine displacement), increased fuel efficiency, and reduced emissions. Computer systems and software have greatly advanced reciprocating engine design and control, accelerating advanced engine designs and making possible more precise control and diagnostic monitoring of engine operation. Stationary engine manufacturers and worldwide engine R\&D firms continue to drive advanced engine technology, including accelerating the diffusion of technology and concepts from the automotive market to the stationary engine market.

The emissions signature of natural gas SI engines, in particular, has improved significantly in the past decade through better design and control of the combustion process and through the use of catalytic treatment of exhaust gases. Advanced lean-burn natural gas engines are available that produce untreated $\mathrm{NO}_{\mathrm{x}}$ levels as low as 50 ppmv @ 15\% reference $\mathrm{O}_{2}$ (dry basis).

\subsection{Applications}

Reciprocating engines are well suited to a variety of distributed generation applications and are widely used in the United States and Europe in power-only - as well as combined heat and power (CHP) - configurations in the industrial, commercial, and institutional market sectors. The widespread use of reciprocating engines in stationary applications in the United States is supported by a highly developed sales and service infrastructure. Reciprocating engines start quickly, follow load well, have good part-load efficiencies, maintain efficiency and output at increasing altitude and ambient conditions, and generally have high reliabilities. In many cases, multiple reciprocating engine generating sets are used to ensure overall plant capacity and maintain high levels of reliability and availability. Reciprocating engines have higher electrical efficiencies, and thus lower fuel-related operating costs, than gas turbines of comparable size. In addition, the first costs of reciprocating engine generator sets are generally lower than gas turbine gensets up to 3-5 MW output range. Reciprocating engine maintenance costs per $\mathrm{kW}-\mathrm{hr}$ are generally higher than equivalent-sized gas turbines, but the engine maintenance often can be performed by in-house staff or provided by local service organizations.

Potential distributed generation applications for reciprocating engines include standby, peak shaving, grid support, and CHP applications in which engine waste heat is utilized to produce hot water, low-pressure steam, or chilled water through waste-heat-fired absorption chillers. Reciprocating engines also are used extensively as direct mechanical drives in applications such as water pumping, air and gas compression, and chilling/refrigeration. 


\subsection{Power-Only}

\section{Standby Power}

Standby power systems are required by fire and safety codes for hospitals, elevator loads, and water pumping. The standby genset is typically the simplest distributed generation system, providing power only when the primary source is out of service or falters in its voltage or frequency. This application typically requires low capital cost, minimal installation costs, blackstart capability (ability to start when the grid supply is interrupted), and grid-isolated operation. Due to the relatively low number of operating hours typically required in standby power applications, efficiency, emissions, and variable maintenance costs are not major factors in technology selection. Installation typically requires a concrete pad and possibly an enclosure or building, controls, and transfer switch appropriate to the application. Multiple units may be used, depending on the size and priorities assigned to the loads that are being protected. Diesel engines are highly preferred for standby power due to their low capital cost, rapid start-up capability (within 10 seconds), and excellent load-following (transient response) characteristics. Standby applications range from a few $\mathrm{kW}$ to very large capacities (up to $10 \mathrm{MW}$ ) in industrial or utility applications. However, most are high-speed units under $2 \mathrm{MW}$. Diesel engines typically can be installed in standby applications without being required to meet strict emissions standards, although operation is limited to a certain number of hours per year (generally 300 to 500 hours). Standby applications are not considered priority applications for natural gas-fueled engines.

\section{Peak Shaving}

In certain areas, customers and utilities are using on-site power generation to reduce the cost of peak load power. Peak shaving is beneficial to customers who have poor load factors and/or high electricity provider demand charges. Typically, peak shaving does not involve heat recovery, but heat recovery may be cost effective if the peak period is more than about 2,000 hours/year. Since low equipment cost and high reliability are the primary requirements, reciprocating engines are ideal for many peak-shaving applications. Emissions may be an issue if the annual number of operating hours is high or the operating facility is located in a nonattainment area. Where peak shaving can be combined with another function, such as standby or emergency power, the economics are considerably enhanced.

There are three possible peak-shaving strategies. First, customers can independently optimize the use of purchased versus generated power under the applicable rate structures. Under this strategy, on-site generation would operate during the utility-defined, more costly peak periods. This creates an operating strategy that can vary, depending on the tariff, from 900 to as many as 3,500 hours/year. Second, some utilities offer coordinated peak-shaving programs in which the utility offers payments for limited hours of use upon request from the utility. This strategy typically requires 50 to 400 hours/year of operation. Third, for customers that purchase power competitively on the open market, there is an opportunity to peak shave from the hourly competitive price or to select competitive power supply contracts that are interruptible. In the competitive market application, the hours of operation would probably be closer to the reduced hours of the coordinated utility model than the independent peak shaving of a published tariff. 
The optimal technology configuration and the need to take into account the value of standby power capability differ markedly among these operating strategies.

\section{Grid Support}

There are many utility owned-and-operated reciprocating engine generating systems in the United States and abroad. The primary applications in the United States have used relatively large diesel or natural gas engines for peaking or intermediate load service at municipal utilities and electric cooperatives. It should be noted that electric utilities often use reciprocating engines at large power plants for plant or grid black-start capabilities. However, a growing number of reciprocating engines now are being placed by utilities at substations to provide incremental peaking capacity and grid support. Such installations can defer the need for T\&D system expansion, provide temporary peaking capacity within constrained areas, or be used for system power factor correction and voltage support, thereby reducing costs for both customers and the utility company. Both diesel engines and natural gas engines are suitable for such service, but the low duty cycle of most grid support applications allows, and often favors, the use of lower-cost diesel units in many areas. A number of stationary engine manufacturers and packagers offer mobile engine generator units (both diesel and natural gas) of various sizes (up to about $2 \mathrm{MW}$ ) that can be used in one location during a period of high peak demand and then moved by truck to another location for the following period, often within the same operating season.

\subsection{Combined Heat and Power}

While the use of reciprocating engines is expected to grow in both grid support and customer peak-shaving applications, the most prevalent on-site generation application for natural gas SI engines has traditionally been CHP. This trend is likely to continue due to the cost effectiveness of heat recovery and growing government recognition of the benefits of CHP. The economics of natural gas engines in on-site generation applications are enhanced by effective use of the thermal energy contained in the exhaust gas and cooling systems, which is generally equal to $60 \%$ to $70 \%$ of the input fuel energy.

There are four sources of usable waste heat from a reciprocating engine: exhaust gas, engine jacket cooling water, lube oil cooling water, and charge air cooling. Heat is generally recovered in the form of hot water or low-pressure steam ( $<30 \mathrm{psig}$ ). Medium pressure steam (up to about 150 psig) can be generated from the engine's high-temperature exhaust gas, but the hot exhaust gas contains only about one-half of the available thermal energy from a reciprocating engine resulting in correspondingly lower overall system efficiency. Some industrial CHP applications use the engine exhaust gas directly for process drying. Generally, the hot water and low-pressure steam produced by reciprocating engine CHP systems is appropriate for low temperature $\left(<240^{\circ} \mathrm{F}\right)$ process needs, space heating, potable water heating, and to drive absorption chillers that provide cold water for process cooling, air conditioning, or refrigeration.

There were an estimated 1,055 engine-based CHP systems operating in the United States in 2000, representing more than $800 \mathrm{MW}$ of electric power capacity as shown in Figure 1. Facility capacities range from $30 \mathrm{~kW}$ to more than $40 \mathrm{MW}$, with many larger facilities comprised of 
multiple units. Reciprocating engine CHP is installed in a variety of applications, with sparkignited engines fueled by natural gas or other gaseous fuels representing $84 \%$ of the installed reciprocating engine CHP capacity in the United States.

\section{Figure 1. Existing Reciprocating Engine CHP - 801 MW at 1,055 sites}

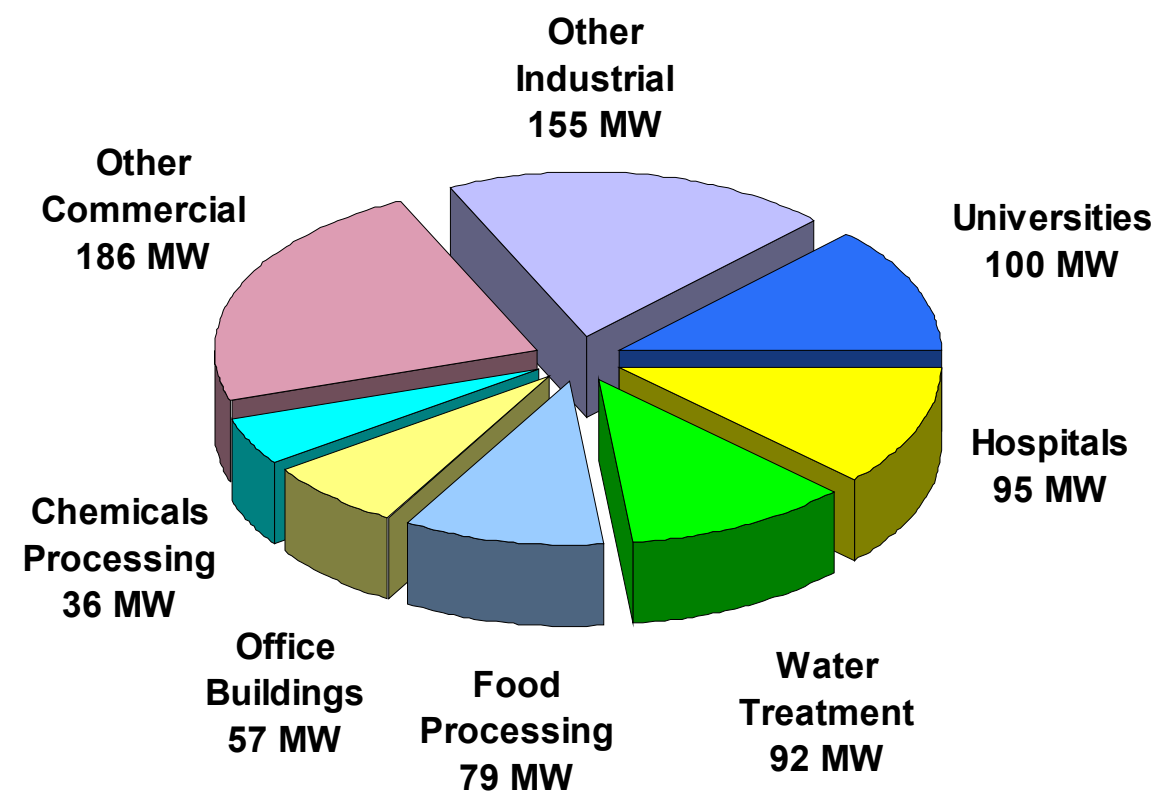

Source: Energy and Environmental Analysis, Inc., CHP Database - 2000

The thermal loads most amenable to engine-driven CHP systems in commercial/institutional buildings are space heating and hot water requirements. The simplest thermal load to supply is hot water. As shown in Figure 1, primary applications for CHP in the commercial/institutional sectors are building types with relatively high and coincident electric and hot water demand, such as colleges and universities, hospitals and nursing homes, and lodging. Office buildings and certain warehousing and mercantile/service applications - can be economically feasible CHP applications if their space heating needs occur at the same time as their electrical needs. Technology development efforts targeted at heat-activated cooling/refrigeration and thermally regenerated desiccants are designed to expand the application of engine-driven CHP by increasing the thermal energy loads in certain building types. Use of CHP thermal output for absorption cooling and/or desiccant dehumidification could increase the market potential and improve the economics of CHP systems in existing CHP markets, such as schools, lodging, nursing homes, and hospitals. Use of these advanced technologies in applications such as restaurants, supermarkets, and refrigerated warehouses would provide base thermal loads that could further open these markets to CHP.

A typical commercial application for reciprocating engine CHP is a hospital or health-care facility with a $1 \mathrm{MW}$ base-load electric demand. In such an application, multiple 200 to $300 \mathrm{~kW}$ natural gas engine-generator sets could be utilized to meet the electric demand. Approximately 1.6 MW thermal $\left(\mathrm{MW}_{\text {th }}\right)$ of hot water would be recovered from engine exhaust and engine 
cooling systems to provide space heating and domestic hot water to the facility and to drive absorption chillers for space conditioning during summer months. Overall efficiency of this type of CHP system can approach $80 \%$.

As shown in Figure 1, engine-driven CHP also is being used in a variety of industrial applications where hot water or low-pressure steam is required for process needs or space heating. A typical industrial application for $\mathrm{CHP}$ would be at a food-processing plant with a 2 MW natural gas engine-driven CHP system comprised of multiple 500 to $800 \mathrm{~kW}$ engine generators. The system would meet the base-load power requirement of the facility and approximately $2.2 \mathrm{MW}_{\text {th }}$ low-pressure steam for process heating and/or space conditioning. Overall efficiency for a CHP system of this type may approach $75 \%$.

\subsection{Technology Description}

\subsection{Basic Process and Components}

There are two primary reciprocating engine designs relevant to stationary power generation applications - the spark ignition Otto-cycle engine and the compression ignition Diesel-cycle engine. The essential mechanical components of Otto-cycle and Diesel-cycle engines are the same. Both have cylindrical combustion chambers, in which closely fitting pistons travel the length of the cylinders. The pistons are connected to a crankshaft by connecting rods that transform the linear motion of the pistons into the rotary motion of the crankshaft. Most engines have multiple cylinders that power a single crankshaft.

The primary difference between the Otto and Diesel cycles is the method of igniting the fuel. Otto-cycle engines use a spark plug to ignite the premixed air-fuel mixture after it is introduced into the cylinder. Diesel-cycle engines compress the air introduced into the cylinder to a high pressure, raising its temperature above the auto-ignition temperature of the fuel, which is then injected into the cylinder at high pressure.

Reciprocating engines are further categorized by crankshaft speed (rpm), operating cycle (2- or 4-stroke), and whether turbocharging is used. These engines also are categorized by their original design purpose - automotive, truck, industrial, locomotive, or marine. Many automotive engine models are used in hundreds of small-scale stationary power, CHP, irrigation, and chiller applications. These engines are generally low-cost, due to large production volumes. However, unless these engines are conservatively rated, they have limited durability. Truck engines have the cost benefit of production volume, are designed for long life (e.g., 1 million miles), and offer longer durability than automotive engines in stationary applications. A number of truck engines are available as stationary engines. Engines intended for industrial use are designed for durability and for a wide range of mechanical drive and electric power applications. Their sizes range from $20 \mathrm{~kW}$ to more than $7 \mathrm{MW}$, including industrialized truck engines in the 200 to 600 $\mathrm{kW}$ range and industrially applied marine and locomotive engines above $1 \mathrm{MW}$.

Both the spark-ignition and the diesel 4-stroke engines, most prevalent in stationary powergeneration applications complete a power cycle in four strokes of the piston within the cylinder: 
1. Intake stroke - introduction of air or fuel-air mixture into the cylinder.

2. Compression stroke - compression of air or fuel-air mixture within the cylinder. In diesel engines, the fuel is injected near the end of the compression stroke (often referred to as top dead center or TDC), and ignited by the high temperature of the compressed air in the cylinder. In spark-ignition engines, the compressed fuel-air mixture is ignited by an ignition source, such as a spark plug, at or near TDC.

3. Power stroke - acceleration of the piston due to the expansion of the hot, high-pressure combustion gases, and

4. Exhaust stroke - expulsion of combustion products from the cylinder through the exhaust valve.

\subsection{Types of Reciprocating Engines}

Natural Gas Spark-Ignition Engines - Spark-ignition engines use spark plugs, with a carefully controlled high-intensity spark, to ignite a compressed fuel-air mixture within the cylinder. In the United States, natural gas is the predominant spark-ignition engine fuel used in electricity generation and CHP applications. Other gaseous and volatile liquid fuels, ranging from landfill gas to propane to gasoline, can be used with the proper fuel system, engine compression ratio, and tuning. American manufacturers began to develop large natural gas engines for the burgeoning natural gas transmission industry after World War II. Smaller engines were developed (or converted from diesel engine blocks) for gas gathering and other stationary applications as the natural gas infrastructure developed. Natural gas engines for power generation applications are primarily 4-stroke engines, available in sizes up to $7 \mathrm{MW}$.

Two ignition techniques are employed with natural gas spark-ignition engines, depending on engine size:

- In open-chamber engines, the spark plug tip is exposed in the combustion chamber of the cylinder, directly igniting the compressed fuel-air mixture. Open chamber ignition is typical of engines that operate near the stoichiometric air/fuel ratio or with moderately lean fuel-air mixtures.

- Precombustion-chamber engines use a staged combustion process, in which the spark plug is housed in a small chamber in the cylinder head. This chamber is charged with a rich mixture of fuel and air, which, upon ignition, expands into the main combustion chamber in the cylinder acting as a high-energy torch. This technique provides sufficient ignition energy to ignite the very lean fuel-air mixtures used in large-bore (large piston diameter) engines.

The simplest natural gas engines operate with natural aspiration of air and fuel into the cylinder (via a carburetor or other mixer) by the suction of the intake stroke. High-performance natural gas engines are turbocharged to force more air into the cylinders, allowing a corresponding 
increase of fuel to increase engine output. Natural gas spark-ignition engines operate at modest compression ratios (compared with diesel engines) in the range of 9:1 to 12:1, depending on engine design and turbocharging. The use of higher compression ratios could lead to autoignition of the fuel, resulting in engine knock, which can cause serious engine damage. ${ }^{4}$

By using high-energy ignition technology, very lean fuel-air mixtures can be burned in natural gas engines, lowering peak temperatures within the cylinders and resulting in reduced $\mathrm{NO}_{\mathrm{x}}$ emissions. The lean-burn approach in reciprocating engines is analogous to dry low- $\mathrm{NO}_{\mathrm{x}}$ combustors in gas turbines. All major natural gas engine manufacturers offer lean-burn, lowemission models and are engaged in R\&D to further improve their performance.

Natural gas spark-ignition engines are typically less efficient than diesel engines because of their lower compression ratios. However, large, high-performance lean-burn engine efficiencies approach those of diesel engines of the same size. Natural gas engine efficiencies range from about $28 \%$ (LHV) for engines smaller than $50 \mathrm{~kW}$, to $40 \%$ (LHV) for the larger highperformance, lean-burn engines. Lean-burn engines tuned for maximum efficiency may emit more than twice as much $\mathrm{NO}_{\mathrm{x}}$ as the same engine tuned for minimum $\mathrm{NO}_{\mathrm{x}}$. Tuning for low $\mathrm{NO}_{\mathrm{x}}$ typically results in a sacrifice of 1 to 1.5 percentage points in electric-generating efficiency from the highest level achievable.

Many natural gas spark-ignition engines are derived from diesel engines, i.e., they are built using the same block, crankshaft, main bearings, camshaft, and connecting rods as the diesel engine. However, natural gas spark-ignition engines operate at lower brake mean effective pressure (BMEP) and peak pressure levels to prevent knock. ${ }^{5}$ Due to the derating effects from lower BMEP, the spark-ignition versions of diesel engines often produce only $60 \%$ to $80 \%$ of the power output of the parent diesel engine. Manufacturers often enlarge cylinder bore about 5\% to $10 \%$ to increase the power, but this is only partial compensation for reduced BMEP.

Consequently, the $\$ / \mathrm{kW}$ capital costs of natural gas spark-ignition engines are generally higher than the diesel engines from which they were derived. However, by operating at lower cylinder pressure and bearing loads, as well as in the cleaner combustion environment of natural gas, spark ignition engines generally offer the benefits of extended component life and lower emissions than their diesel parents.

Diesel Engines - Compression ignition diesel engines are among the most efficient simple-cycle, power-generation options on the market. Efficiency levels increase with engine size and range from about $32 \%$ (LHV) for small high-speed diesels up to $45 \%$ to $50 \%$ (LHV) for the large-bore, slow-speed engines. High-speed diesel engines (1,000 to 3,600 rpm) are available up to about 4 MW in size. Low-speed diesels (60 to $275 \mathrm{rpm}$ ) are available as large as $80 \mathrm{MW}$.

\footnotetext{
4 "Knock" is produced by explosive auto-ignition of a portion of the fuel in the cylinder due to compression and heating of the gas mixture ahead of the flame front. The terms "knock" and "detonation" are often used interchangeably.

${ }^{5}$ Brake mean effective pressure (BMEP) can be regarded as the "average" cylinder pressure on the piston during the power stroke and is a measure of the specific loads on the engine. BMEP is generally an indication of how well the engine utilizes total cylinder displacement in creating useful work.
} 
Diesel engines typically require compression ratios of $12: 1$ to $17: 1$ to heat the cylinder air to a temperature that will auto-ignite the injected fuel. The quality of fuel injection significantly affects diesel-engine operating characteristics, fuel efficiency, and emissions. Fine atomization and good fuel dispersion by the injectors are essential for rapid ignition, ideal combustion, and emissions control. Manufacturers are increasingly moving toward electronically controlled, high-pressure injection systems that provide more precise calibration and control of fuel delivery and accurate injection timing.

Depending on the engine and fuel quality, diesel engines produce 5 to 20 times as much $\mathrm{NO}_{\mathrm{x}}$ (on a ppmv basis) as lean-burn natural gas engines. Diesel engines also produce assorted heavy hydrocarbons and particulate emissions. However, diesel engines produce significantly less $\mathrm{CO}$ (carbon monoxide) than lean-burn gas engines. The $\mathrm{NO}_{\mathrm{x}}$ emissions from diesels burning heavy fuel oil are typically $25 \%$ to $30 \%$ higher than diesels using distillate oil. Common $\mathrm{NO}_{\mathrm{x}}$ control techniques include delayed fuel injection, exhaust gas recirculation, water injection, fuel-water emulsification, and compression ratio and turbocharger modifications - all designed to eliminate hot spots and reduce the flame temperature within the cylinder. In addition, an increasing number of larger diesel engines are equipped with selective catalytic reduction (SCR) and oxidation catalyst systems for post-combustion emissions reduction.

High-speed diesel engines generally require high-quality fuel oil with good combustion properties. No. 1 and No. 2 distillate oil comprise the standard diesel fuels. Low sulfur distillate is preferred for minimizing $\mathrm{SO}_{2}$ emissions. High-speed diesels are not suited to burning oil heavier than light distillates. Lower-quality heavy fuel oil burns too slowly and contains contaminants that would cause excessive wear in high-speed diesel engines. Many medium- and low-speed diesels are designed to burn heavier oils, including low-grade residual oil (Bunker C oil).

Dual-Fuel Engines - Dual-fuel engines are diesel-cycle compression ignition engines predominantly fueled by natural gas with a small percentage of diesel oil used as a "pilot" fuel. Compression heating auto-ignites the pilot fuel and initiates combustion of the main fuel-air mixture. Pilot fuel minimum requirements can range from $1 \%$ to $20 \%$ of total fuel input. Dualfuel operation is a combination of Diesel- and Otto-cycle operation, approaching the Otto cycle more closely at low pilot-fuel percentages. Most dual-fuel engines can be switched between dual-fuel and $100 \%$ diesel operation while the engine is operating at any output level. In general, due to lower diesel oil use, $\mathrm{NO}_{\mathrm{x}}$, smoke, and particulate emissions are lower for dual-fuel engines than for straight diesel operation, particularly at full load. Particulate emissions are reduced in line with the percentage reduction in diesel oil consumption, while the level of $\mathrm{NO}_{\mathrm{x}}$ reduction depends on combustion characteristics (see Emissions section). However, $\mathrm{CO}$ and unburned hydrocarbon emissions are often higher as a result of incomplete combustion. High first costs and maintenance costs - plus added operational complexity of dual-fuel engines generally are barriers or a deterrent to consumer deployment.

There are three basic types of dual-fuel engines:

Conventional, low-pressure, gas-injection engines typically require about $5 \%$ to $10 \%$ pilot fuel and may be derated to about $80 \%$ to $95 \%$ of the rated diesel capacity to avoid knock. The 
minimum pilot-fuel requirement is generally set by the turndown ratio of the diesel fuel-injection system (limited by the smallest amount of fuel that the injection system can normally supply). Conventional diesel injectors cannot reliably turn down to less than $5 \%$ to $6 \%$ of the full-load injection rate. Natural gas input is controlled at each cylinder by injecting gas before the air intake valves open. $\mathrm{NO}_{\mathrm{x}}$ emissions of conventional dual-fuel engines are generally in the 3.5 to $6.0 \mathrm{~g} / \mathrm{bhp}-\mathrm{hr}$ range (compared to lean-burn natural gas engines with $\mathrm{NO}_{\mathrm{x}}$ emissions in the 0.5 to $2.0 \mathrm{~g} / \mathrm{bhp}-\mathrm{hr}$ range).

High-pressure gas-injection engines attempt to reduce derating by injecting natural gas at high pressures (3,600 to 5,100 psig) directly into the main combustion chamber while the pilot fuel is injected. However, the parasitic power required for gas compression can be as high as $4 \%$ to $7 \%$ of the rated power output - partly offsetting the benefit of reduced derating. This technology has not proved particularly popular because of this issue and the cost of additional equipment required for high-pressure gas injection. Pilot-fuel consumption is typically $3 \%$ to $8 \%$, and $\mathrm{NO}_{\mathrm{x}}$ emissions are generally in the 3.5 to $6.0 \mathrm{~g} / \mathrm{bhp}-\mathrm{hr}$ range.

Micropilot prechamber engines are similar to spark-ignition precombustion-chamber engines in that the pilot fuel injected into a prechamber provides a high-energy torch that ignites the very lean, compressed fuel-air mixture in the cylinder. Leaner mixtures than those of spark-ignition engines are achievable because the energy provided by the diesel-fueled micropilot chamber is higher than that obtained with a spark-ignition prechamber. Micropilot dual-fuel engines with $1 \%$ pilot fuel can operate at or near diesel engine compression ratios and BMEPs; so little, if any, derating occurs. In this case, the high power density and low $\$ / \mathrm{kW}$ cost advantage of the original diesel engine are retained, and engine efficiency at $75 \%$ to $100 \%$ of full load is close to that of the diesel engine. $\mathrm{NO}_{\mathrm{x}}$ and other emissions are comparable to those of lean-burn, sparkignition prechamber engines $\left(\mathrm{NO}_{\mathrm{x}}\right.$ emissions in the 0.5 to $2.0 \mathrm{~g} / \mathrm{bhp}-\mathrm{hr}$ range). These engines must be equipped with conventional diesel fuel injectors in order to operate on $100 \%$ diesel.

Several independent developers and engine manufacturers are testing and commercializing dualfuel retrofit kits for converting existing diesel engines to dual-fuel operation. The level of sophistication of these kits varies widely, and some require major engine modifications. Derating, efficiencies, and emissions also vary widely and have yet to be fully tested or certified. However, dual-fuel conversions are not expected to be as low in emissions as dedicated natural gas engines. In addition, manufacturers may not honor warranties on engines that have been retrofitted by an independent third party.

Engine-Speed Classifications - Reciprocating engines are classified as high-, medium-, or lowspeed. Table 1 presents the standard speed ranges in each class and the types and sizes of engines available. Engine-driven electric generators typically must run at fixed (or synchronous) speeds and maintain a constant 50 or $60 \mathrm{Hertz}(\mathrm{Hz})$ frequency, which dictates the required engine operating speed (i.e., a $60 \mathrm{~Hz}$ generator driven by a high-speed engine would require engine speeds of $1,200,1,800$ or $3,600 \mathrm{rpm}$ in contrast to a $50 \mathrm{~Hz}$ generator, which requires engine speeds of $1,000,1,500$ or $3,000 \mathrm{rpm}$ ) 
Table 1. Reciprocating Engine Types by Speed (Available MW Ratings)

\begin{tabular}{|l|c|c|c|c|c|}
\hline $\begin{array}{c}\text { Speed } \\
\text { Classification }\end{array}$ & $\begin{array}{c}\text { Engine } \\
\text { Speed, } \\
\text { rpm }\end{array}$ & $\begin{array}{c}\text { Stoic/ Rich } \\
\text { Burn, Spark } \\
\text { Ignition }\end{array}$ & $\begin{array}{c}\text { Lean Burn, } \\
\text { Spark Ignition }\end{array}$ & Dual Fuel & Diesel \\
\hline High Speed & $1,000-600$ & $0.01-1.5 \mathrm{MW}$ & $0.15-3.0 \mathrm{MW}$ & $1.0-3.5 \mathrm{MW}^{7}$ & $0.01-3.5 \mathrm{MW}$ \\
Medium Speed & $275-1,000$ & None & $1.0-7.0 \mathrm{MW}$ & $1.0-25 \mathrm{MW}$ & $0.5-35 \mathrm{MW}$ \\
Low Speed & $60-275$ & None & None & $2.0-65 \mathrm{MW}$ & $2.0-80 \mathrm{MW}$ \\
\hline
\end{tabular}

Source: SFA Pacific, Inc., "Reciprocating Engines for Stationary Power Generation"

The specific power output of engines is proportional to engine speed, affording high-speed engines the highest output per unit of displacement (cylinder size) and the highest power density. Consequently, high-speed engines generally have the lowest $\$ / \mathrm{kW}$ production costs. However, the cost benefits of high-speed engines must be weighed against other factors. Smaller highspeed engines tend to have lower efficiencies than larger-bore, slower engines, due in part to the higher surface area to volume ratios of small cylinders, which result in higher heat losses. Also, high-speed engines tend to have higher wear rates, resulting in shorter periods between both minor and major overhauls. These factors often are less important than capital cost for limited duty cycle applications, such as standby and emergency.

Medium-speed stationary power engines are largely derived from marine and locomotive engines. Medium-speed engines are costlier and heavier, but generally more efficient and durable than high-speed engines.

Because of their massive physical size, capital cost, and lengthy fabrication times, low-speed engines are increasingly being displaced by medium- and high-speed engines as the primary choice for stationary power applications.

Load Service Ratings - Reciprocating engine manufacturers typically assign one of three power ratings to engines, depending on the intended load service:

- Standby - continuous full or cycling load for a relatively short duration (usually less than 100 hours per year) - maximum power output rating

- Prime - continuous operation for an unlimited time (except for normal maintenance shutdowns), but with regular variations in load - $80 \%$ to $85 \%$ of the standby rating

- Base-load - continuous full-load operation for an unlimited time (except for normal maintenance shutdowns) $-70 \%$ to $75 \%$ of the standby rating.

\footnotetext{
${ }^{6}$ Stoichiometric or rich-burn combustion is required for the use of three-way catalytic converters for emissions control.

${ }^{7}$ Micropilot, prechamber dual-fuel engines.
} 


\subsection{Design Characteristics}

The features that affect the use of reciprocating engines for CHP and other distributed generation applications include:

Size range:

Thermal output:

Fast start-up:

Black-start capability:

Availability:

Part-load operation:

High altitude:

High ambient

temperature:

Reliability and life:

Emissions:
Natural gas reciprocating engines are available in sizes from 10 $\mathrm{kW}$ to more than $7 \mathrm{MW}$ and can be matched to the electric demand of many end users (institutional, commercial, and industrial).

Reciprocating engines can produce hot water and low-pressure steam for a variety of combined heat and power applications.

In peaking or emergency power applications, reciprocating engines can quickly supply electricity on demand. The fast start-up capability of reciprocating engines allows timely resumption of the system following a maintenance procedure.

In the event of an electric utility outage, reciprocating engines can be started with minimal auxiliary power requirements. Generally only batteries or a compressed air source is required for starting.

Reciprocating engines have typically demonstrated availability in excess of $96 \%$ in stationary power generation applications.

The high part-load efficiency of reciprocating engines ensures economical operation in electric-load-following applications.

Modern reciprocating engines generally maintain emissions and efficiency capability at altitudes up to 5,000 feet.

Modern reciprocating engines generally maintain emissions and efficiency capability at ambient temperatures up to $110^{\circ} \mathrm{F}$, depending on fuel source.

Reciprocating engines have proven to be reliable power generators, given proper maintenance.

Diesel engines have relatively high emissions levels of $\mathrm{NO}_{\mathrm{x}}$ and particulates. However, natural gas spark ignition engines have better emissions profiles and can be sited in most nonattainment areas. 


\subsection{Cost and Performance Characteristics}

This section describes the cost and performance of natural gas reciprocating engine systems for two primary applications. The first is for systems designed to produce power only. Systems configured for this purpose could be used in a variety of the applications described in Section 2, including standby power, peaking, and grid support. The second configuration discussed in this section is combined heat and power (CHP), where additional equipment is added to the basic engine to allow recovery and subsequent use of jacket cooling and exhaust heat in industrial processes or commercial buildings. While CHP systems have many of the characteristics of power-only systems, they have additional complexity and require design tradeoffs that are described in this section.

\subsection{System Performance}

Table 2 provides an overview of performance characteristics and cost of typical natural gas spark-ignition engine systems commercially available in 2003. Performance characteristics are shown in the top portion of the table and apply to both power-only and CHP applications. Total installed cost estimates are provided for both applications. The size range included in the table, $100 \mathrm{~kW}$ to $5 \mathrm{MW}$, covers the majority of the market applications for engine-driven power-only and CHP applications. The heat rates and efficiencies shown were taken from manufacturers' specifications and industry publications. Available thermal energy was calculated from published data on engine exhaust temperatures and engine jacket and lube system coolant flows. $\mathrm{CHP}$ thermal recovery estimates are based on producing hot water for process or space-heating needs.

As shown in the table, $50 \%$ to $60 \%$ of the waste heat from engine systems is recovered from jacket cooling water and after-cooler/lube oil cooling systems at temperatures too low to produce steam. This lower-temperature characteristic is generally less critical in commercial/institutional applications, where hot water is a common thermal need. Steam can be produced from the exhaust heat if required (maximum pressures in the range of $150 \mathrm{psig}$ ). Whether steam based or hot water based, if the building or process thermal requirement is less than the amount of usable recoverable heat, the excess heat much be rejected to atmosphere, and the total CHP system efficiency drops accordingly. An alternate operating strategy decreases generator output to match the thermal demand.

The data in the table show that electrical efficiency increases as engine size becomes larger. As electrical efficiency increases, the absolute quantity of thermal energy available to produce useful thermal energy decreases per unit of power output, and the ratio of power to heat for the CHP system generally increases. The ratio of power to heat impacts project economics and may affect the decisions that customers make in terms of CHP acceptance, sizing, and the desirability of selling power. 
Table 2. Reciprocating Engine Systems - Typical Performance Parameters (2003)

\begin{tabular}{|c|c|c|c|c|c|}
\hline Cost and Performance Characteristics ${ }^{8}$ & $\begin{array}{c}\text { System } \\
1\end{array}$ & $\begin{array}{c}\text { System } \\
2\end{array}$ & $\begin{array}{c}\text { System } \\
3\end{array}$ & $\begin{array}{c}\text { System } \\
4\end{array}$ & $\begin{array}{c}\text { System } \\
5\end{array}$ \\
\hline Nominal Capacity (kW) & 100 & 300 & 1,000 & 3,000 & 5,000 \\
\hline \multicolumn{6}{|l|}{ Engine Characteristics } \\
\hline Engine Combustion & Rich & Lean & Lean & Lean & Lean \\
\hline Electrical Efficiency (\%), LHV & 33 & 34 & 38 & 39 & 41 \\
\hline Electric Heat Rate (Btu/kWh), $\mathrm{HHV}^{9}$ & 11,500 & 10,967 & 10,035 & 9,700 & 9,213 \\
\hline Electrical Efficiency (\%), HHV & 30 & 31 & 34 & 35 & 37 \\
\hline Fuel Input (MMBtu/hr) & 1.15 & 3.29 & 10.05 & 29.1 & 46.1 \\
\hline Engine Speed (rpm) & 1,800 & 1,800 & 1,200 & 900 & 720 \\
\hline Installed Cost - Power Only (2003 \$/kW) & 1,030 & 790 & 720 & 710 & 695 \\
\hline Installed Cost - CHP $(2003 \$ / k W)^{10}$ & 1,350 & 1,160 & 945 & 935 & 890 \\
\hline O\&M Costs, $(2003 \$ / \mathrm{kWh})$ & 0.018 & 0.013 & 0.009 & 0.009 & 0.008 \\
\hline Required Fuel Gas Pressure (psig) & $<3$ & 18 & $3-43$ & 43 & 65 \\
\hline \multicolumn{6}{|l|}{ CHP Characteristics } \\
\hline Exhaust Flow $(1,000 \mathrm{lb} / \mathrm{hr})$ & 1.0 & 3.5 & 12.4 & 48.4 & 75.6 \\
\hline Exhaust Temperature $\left({ }^{\circ} \mathrm{F}\right)$ & 1,060 & 1,057 & 914 & 707 & 745 \\
\hline Heat Available - Exhaust (MMBtu/hr) ${ }^{11}$ & 0.29 & 0.89 & 2.11 & 5.48 & 9.63 \\
\hline Heat Available - High Temp Cooling (MMBtu/hr) ${ }^{12}$ & 0.27 & 0.63 & 1.59 & 4.37 & 7.04 \\
\hline Heat Available - Low Temp Cooling (MMBtu/hr) ${ }^{13}$ & 0 & 0.12 & 0.85 & 1.22 & 1.38 \\
\hline Total Heat Recovered (MMBtu/hr) $)^{14}$ & 0.56 & 1.52 & 3.70 & 9.84 & 16.66 \\
\hline Total Heat Recovered (kW equivalent) & 164 & 445 & 1,084 & 2,884 & 4,883 \\
\hline Form of Recovered Heat & Hot $\mathrm{H}_{2} \mathrm{O}$ & Hot $\mathrm{H}_{2} \mathrm{O}$ & 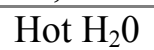 & $\mathrm{Hot}_{2} \mathrm{O}$ & Hot $\mathrm{H}_{2} \mathrm{O}$ \\
\hline Total CHP Efficiency $(\%)^{15}$ & 78 & 77 & 71 & 69 & 73 \\
\hline Heat/Fuel Ratio ${ }^{16}$ & 0.49 & 0.46 & 0.37 & 0.34 & 0.36 \\
\hline Power/Heat Ratio ${ }^{17}$ & 0.61 & 0.67 & 0.92 & 1.04 & 1.02 \\
\hline Net Heat Rate $(\mathrm{Btu} / \mathrm{kWh})^{18}$ & 4,500 & 4,641 & 5,422 & 5,599 & 5,049 \\
\hline
\end{tabular}

Source: EEA estimates of characteristics for "typical" commercially available natural gas engine gensets.

\footnotetext{
${ }^{8}$ Data based on manufacturer specifications for: MAN $150 \mathrm{~kW}-100 \mathrm{~kW}$; Cummins GSK19G - $300 \mathrm{~kW}$; Cummins QSV91G - 1 MW; Caterpillar G3616 LE - 3 MW; Wartsila 18V34SG - 5 MW. Energy use and exhaust flows normalized to nominal system sizes.

${ }^{9}$ All engine manufacturers quote heat rates in terms of the lower heating value (LHV) of the fuel. However the purchase price of fuels on an energy basis is typically measured on a higher heating value basis (HHV). For natural gas, the average $\mathrm{HHV}$ is $1030 \mathrm{Btu} / \mathrm{kWh}$ and the average LHV is $930 \mathrm{Btu} / \mathrm{kWh}$ - about a $10 \%$ difference.

${ }^{10}$ Installed costs based on CHP system producing hot water from exhaust heat recovery $\left(250^{\circ} \mathrm{F}\right.$ exhaust outlet from heat recovery heat exchanger) and high temperature cooling loop

${ }^{11}$ Heat available from exhaust heat recovery assumes an exhaust gas outlet temperature from the heat-recovery unit of $250^{\circ} \mathrm{F}$

${ }^{12}$ High-temperature cooling includes jacket cooling and medium temperature after-cooler cooling systems, if applicable - outlet water temperature 190 to $210^{\circ} \mathrm{F}$

${ }^{13}$ Low-temperature cooling includes lube oil cooling and low-temperature after-cooler cooling systems - outlet water temperature 110 to $130^{\circ} \mathrm{F}$

${ }_{15}^{14}$ Total Heat Recovered includes exhaust heat recovery and high temperature cooling heat recovery

${ }^{15}$ Total CHP Efficiency = (net electric power generated + net thermal energy available $) /$ total engine fuel input

${ }^{16}$ Heat/Fuel Ratio $=$ Thermal output (total heat recovered MMBtu/hr) as a fraction of fuel input $(\mathrm{MMBtu} / \mathrm{hr})$

${ }^{17}$ Power/Heat Ratio $=($ CHP electric power output $($ Btu equivalent $)) /$ useful thermal output $(\mathrm{Btu})$

${ }^{18}$ Net Heat Rate $=($ Total fuel input to the CHP system - fuel normally used to generate the same amount of thermal output as the CHP system thermal output, assuming efficiency of $80 \%$ )/CHP electric output (kW).
} 


\section{Part-Load Performance}

In power generation and CHP applications, reciprocating engines generally drive synchronous generators at constant speed to produce steady alternating current (AC) power. As load is reduced, the heat rate of spark-ignition engines increases and efficiency decreases. Figure 2 shows the part-load efficiency curve for a typical lean-burn natural gas engine. The efficiency at $50 \%$ load is approximately $8 \%$ to $10 \%$ less than full-load efficiency. As the load decreases further, the curve becomes steeper. While gas engines compare favorably to gas turbines, which typically experience efficiency decreases of $15 \%$ to $25 \%$ at half-load conditions. Diesel engines exhibit more favorable part-load characteristics than spark-ignition engines. The efficiency curve for diesel engines is comparatively flat between $50 \%$ and $100 \%$ load.

Figure 2. Part-Load Efficiency Performance (Spark-Ignition Engines)

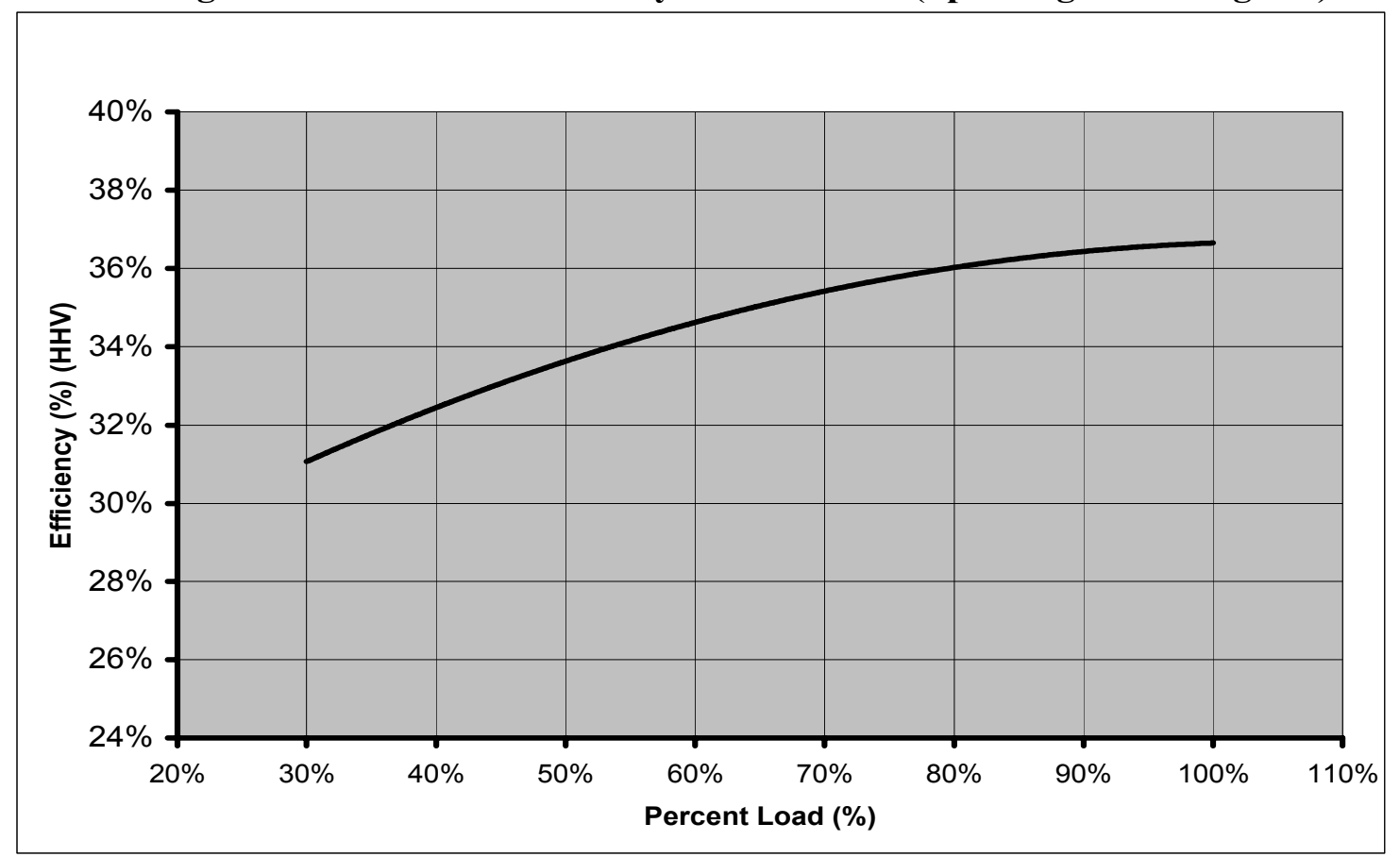

Note: Graph data based on Caterpillar G3616 LE engine specifications

\section{Effects of Ambient Conditions on Performance}

Reciprocating engines are generally rated at ISO conditions of $77^{\circ} \mathrm{F}$ and 0.987 atmospheres $(1$ bar) pressure. Like gas turbines, reciprocating engine performance - both output and efficiency - degrades with the increase of ambient temperature or site elevation. While the effect on gas turbines can be significant, it is less so on engines. As a rule-of-thumb, reciprocating engine power is reduced by approximately $4 \%$ per 1,000 feet of altitude above 1,000 feet, while efficiency decreases about $1 \%$ for every 1,000 feet of altitude. Both engine power and efficiency typically decrease $2 \%$ for every $10^{\circ} \mathrm{F}$ above $110^{\circ} \mathrm{F}$. However, each engine model has its own performance characteristics, which depend on engine-design features, such as turbocharger and intercooler selection. 


\subsection{Combined Heat and Power Performance}

The engine portion of a CHP system generally remains the same as that found in power-only configurations. This section focuses on the heat-recovery system and its performance characteristics.

\section{Heat Recovery}

The economics of engines in on-site power generation applications often depend on effective use of the thermal energy contained in the exhaust gas and cooling systems, which generally represents $60 \%$ to $70 \%$ of the input fuel energy. Most of the waste heat is available in the engine exhaust and jacket water coolant, while smaller amounts can be recovered from the lube oil cooler and the charge air after-cooler (if so equipped). The most common use of this heat is to generate hot water or low-pressure steam for process use or for space heating, domestic hot water, or absorption cooling. However, the engine exhaust gases also can be used as a source of direct energy for drying or other direct-heating processes.

In typical engines, heat in the jacket water or coolant accounts for up to $30 \%$ of the energy input and is capable of producing $200^{\circ} \mathrm{F}$ to $210^{\circ} \mathrm{F}$ hot water. Some engines, such as those with highpressure or ebullient cooling systems, can operate with water jacket temperatures up to $265^{\circ} \mathrm{F}$. Engine exhaust heat represents $30 \%$ to $50 \%$ of the available waste heat. Exhaust temperatures of $850^{\circ} \mathrm{F}$ to $1,200^{\circ} \mathrm{F}$ are typical. By recovering heat from the cooling systems and exhaust, approximately $70 \%$ to $80 \%$ of the fuel's energy can be effectively utilized to produce both power and useful thermal energy.

Closed-loop cooling systems - The most common method of recovering engine heat is the closed-loop cooling system as shown in Figure 3. These systems are designed to cool the engine by forced circulation of a coolant through engine passages and an external heat exchanger. A means of removing excess heat, such as a radiator or cooling tower, is typically required to allow for rejection of the engine heat that is not utilized by the process. If a means of removing excess heat is not installed, at times when the process needs less heat, the engine genset electrical output will need to be reduced to a level where system coolant temperatures can be safely maintained for proper engine operation. Closed-loop water-cooling systems can operate at coolant temperatures from $190^{\circ} \mathrm{F}$ to $250^{\circ} \mathrm{F}$. Depending on engine and $\mathrm{CHP}$ system requirements, the lube oil cooling and turbocharger after-cooling may be either separate or from part of the jacket water-cooling system. 
Figure 3. Closed-Loop Heat-Recovery System

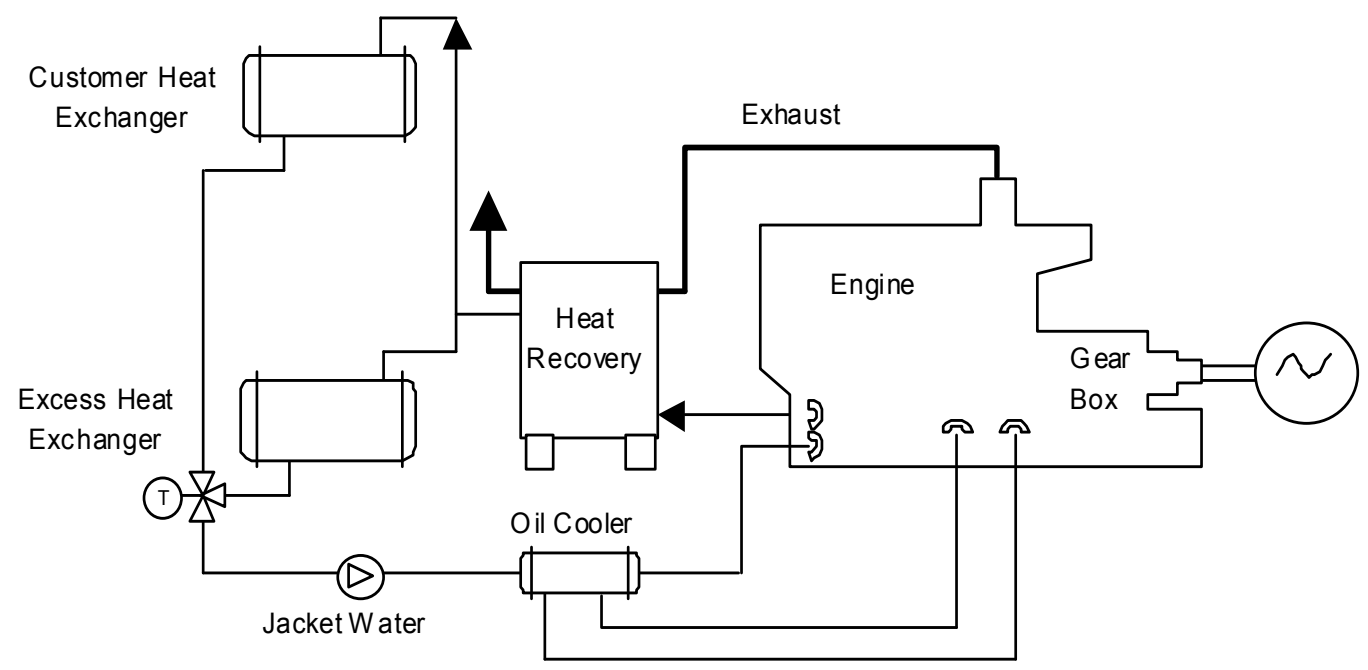

Ebullient Cooling Systems - Ebullient cooling systems cool the engine by natural circulation of a boiling coolant through the engine. This type of cooling system is typically used in conjunction with exhaust heat recovery to produce low-pressure steam. Cooling water is introduced at the bottom of the engine where the transferred heat begins to boil the coolant, generating two-phase flow. The formation of bubbles lowers the density of the coolant, causing a natural circulation to the top of the engine.

The coolant at the engine outlet is maintained at saturated steam conditions that are usually limited by the heat available to $250^{\circ} \mathrm{F}$ and a maximum of $15 \mathrm{psig}$. Inlet cooling water is also near saturation conditions and is generally only $2^{\circ} \mathrm{F}$ to $3^{\circ} \mathrm{F}$ below the outlet temperature. The uniform temperature throughout the coolant circuit extends engine life and contributes to improved combustion efficiencies.

Exhaust Heat Recovery - Exhaust heat is typically used to generate hot water at about $230^{\circ} \mathrm{F}$ or low-pressure steam (up to $150 \mathrm{psig}$ ). Only a portion of the exhaust heat can be recovered, since exhaust gas temperatures are generally kept above $250^{\circ} \mathrm{F}$ to $350^{\circ} \mathrm{F}$ to prevent the corrosive effects of condensation in the exhaust piping.

Exhaust heat recovery can be independent of the engine cooling system or coupled with it. For example, hot water from the engine cooling can be used as feed-water or feed-water preheat to the exhaust recovery unit. In a typical district-heating system, jacket water cooling, lube oil cooling, single-stage after-cooling, and exhaust gas heat recovery are all integrated for steam and/or hot water production. 


\subsection{Performance and Efficiency Enhancements}

\section{Brake Mean Effective Pressure (BMEP) and Engine Speed}

Engine power is related to engine speed and the Brake Mean Effective Pressure (BMEP) during the power stroke. Reciprocating engines can produce more power from a given displacement volume (cubic inches or liters) by increasing engine speed and/or the pressure inside the engine's cylinders. BMEP can be regarded as an "average" cylinder pressure on the piston during engine operation, and is an indication of the specific load on an engine. Engine manufacturers often include BMEP values in their product specifications. Typical BMEP values are as high as 230 psig for large natural gas engines and 350 psig for diesel engines. Corresponding peak combustion pressures are about 1,750 psig and 2,600 psig, respectively. High BMEP levels indicate high specific power output, and generally result in improved efficiency and lower specific capital costs and maintenance costs.

BMEP can be increased by introducing larger volumes of combustion air and fuel into the engine cylinders through improved turbocharging, improved after-cooling, and reduced pressure losses through improved air-passage design. These factors all increase air charge density and raise peak combustion pressures, translating into higher BMEP levels. However, higher BMEP increases thermal and mechanical stresses within the engine combustion chamber and drive-train components, along with a potential increase in the tendency for detonation, depending on fuel type. Proper design and testing is required to ensure continued engine durability and reliability.

\section{Turbocharging}

Essentially, all modern industrial engines above $300 \mathrm{~kW}$ are turbocharged to achieve higher power densities. A turbocharger is basically a turbine-driven intake air compressor. The hot, high-velocity exhaust gases leaving the engine cylinders power the turbine. Very large engines typically are equipped with two large or four small turbochargers. On a carbureted engine, turbocharging forces more air and fuel into the cylinders, increasing engine output. On a fuelinjected engine, the mass of fuel injected must be increased in proportion to the increased air input. Cylinder pressure and temperature normally increase as a result of turbocharging, increasing the tendency for detonation for both spark ignition and dual-fuel engines and requiring a careful balance between compression ratio and turbocharger boost level. Turbochargers normally boost inlet air pressure by a factor of 3 to 4 . A wide range of turbocharger designs and models is used. Heat exchangers (called after-coolers or inter-coolers) are often used to cool the combustion air exiting the turbocharger compressor to keep the temperature of the air to the engine under a specified limit and to increase the air density.

\subsection{Capital Cost}

This section provides estimates for the installed cost of natural gas spark-ignited, reciprocating engine-driven generators. Two configurations are presented: power-only and CHP. Capital costs (equipment and installation) are estimated for the five typical engine genset systems ranging from $100 \mathrm{~kW}$ to $5 \mathrm{MW}$ for each configuration. These are "typical" budgetary price levels to the end user. Installed costs can vary significantly depending on the scope of the plant equipment, geographical area, competitive market conditions, special site requirements, 
emissions control requirements, prevailing labor rates, and whether the installation is a new or retrofit application.

In general, engine gensets do not show the economies of scale that are typical when costing industrial equipment of different sizes. Smaller genset packages are often less costly on a specific cost basis $(\$ / \mathrm{kW})$ than larger gensets. Smaller engines typically run at a higher speed (rpm) than larger engines and often are adaptations of high-production-volume automotive or truck engines. These two factors combine to make the small engines cost less than larger, slower-speed engines.

The basic genset package consists of an engine connected directly to a generator without a gearbox. In countries where $60 \mathrm{~Hz}$ power is required, the gensets run at speeds that are multiples of 60 - typically 1,800 rpm for smaller engines and 900 or $720 \mathrm{rpm}$ for large engines. In areas where $50 \mathrm{~Hz}$ power is used, such as Europe and parts of Japan, the engines run at speeds that are multiples of 50 - typically 1,500 rpm for smaller high-speed engines. The smaller engines are skid-mounted with a basic genset control system, fuel system, radiator, radiator fan, and starting system. Some smaller packages come with an enclosure, integrated heat-recovery system, and basic electric-paralleling equipment. The cost of the basic engine genset package plus the cost for added systems needed for the particular application or site comprise the total equipment cost. The total installed cost includes total equipment cost, plus installation labor and materials (including site work), engineering, project management (including licensing, insurance, commissioning, and startup), and contingency.

Table 3 provides cost estimates for current power-only systems. The estimates are based on a simple installation with minimal site preparation required. These cost estimates are for base-load or extended peaking operation and include provisions for grid interconnection and paralleling. The package costs are intended to reflect a generic representation of popular engines in each size category. The engines all have low emission, lean-burn technology (with the exception of the $100 \mathrm{~kW}$ system, which is a rich burn engine that would require a three-way catalyst in most urban installations). The interconnect/electrical costs reflect the costs of paralleling a synchronous generator, although many $100 \mathrm{~kW}$ packages available today use induction generators that are simpler and less costly to parallel. ${ }^{19}$ However, induction generators cannot operate isolated from the grid and will not provide power to the site when the grid is down. Labor/materials represent the labor cost for the civil, mechanical, and electrical work - as well as materials such as ductwork, piping, and wiring - and is estimated to range from $35 \%$ of the total equipment cost for smaller engines to $20 \%$ for the largest. Project and construction management also includes general contractor markup and bonding, as well as performance guarantees, and is estimated to range from $10 \%$ of the total equipment cost for small engines to $8 \%$ for the largest engines. Engineering and permitting fees are estimated to range from 5\% to $8 \%$ of the total equipment cost depending on engine size. Contingency is assumed to be $5 \%$ of the total equipment cost in all cases.

\footnotetext{
${ }^{19}$ Reciprocating Engines for Stationary Power Generation: Technology, Products, Players, and Business Issues,
} GRI, Chicago, IL and EPRIGEN, Palo Alto, CA: 1999. GRI-99/0271, EPRI TR-113894. 
Table 3. Estimated Capital Cost for Typical Reciprocating Engine-Generators in Grid-Interconnected Power-Only Applications (2003)

\begin{tabular}{|c|c|c|c|c|c|}
\hline Cost Component & $\begin{array}{c}\text { System } \\
1 \\
\end{array}$ & $\begin{array}{c}\text { System } \\
2 \\
\end{array}$ & $\begin{array}{c}\text { System } \\
3 \\
\end{array}$ & $\begin{array}{c}\text { System } \\
4 \\
\end{array}$ & $\begin{array}{c}\text { System } \\
5\end{array}$ \\
\hline Nominal Capacity (kW) & 100 & 300 & 1,000 & 3,000 & 5,000 \\
\hline $\operatorname{Cost}(\$ / k W)$ & & & & & \\
\hline Equipment & & & & & \\
\hline Genset Package & 400 & 350 & 370 & 440 & 450 \\
\hline Interconnect/Electrical & 250 & 150 & 100 & 75 & 65 \\
\hline Total Equipment & 650 & 500 & 470 & 515 & 515 \\
\hline Labor/Materials & 228 & 175 & 141 & 103 & 103 \\
\hline Total Process Capital & 878 & 675 & 611 & 618 & 618 \\
\hline $\begin{array}{l}\text { Project and Construction } \\
\text { and Management }\end{array}$ & 66 & 50 & 47 & 40 & 25 \\
\hline Engineering and Fees & 53 & 40 & 38 & 26 & 26 \\
\hline Project Contingency & 33 & 25 & 24 & 26 & 26 \\
\hline Total Plant Cost $(2003 \$ / \mathrm{kW})$ & $\$ 1,030$ & $\$ 790$ & $\$ 720$ & $\$ 710$ & $\$ 695$ \\
\hline
\end{tabular}

Source: Energy and Environmental Analysis, Inc., estimates

Table 4 shows the cost estimates on the same basis for combined heat and power applications. The CHP systems are assumed to produce hot water, although the multi-megawatt size engines are capable of producing low-pressure steam. The heat recovery equipment consists of an exhaust heat exchanger that extracts heat from the exhaust system, a process heat exchanger that extracts heat from the engine jacket coolant, a circulation pump, a control system, and piping. The CHP system also requires additional engineering to integrate the system with the on-site process. Installation costs are generally higher than power-only installations due to increased project complexity and the higher performance risks associated with system and process integration. Labor/materials, representing the labor cost for the civil, mechanical, and electrical work - as well as materials such as ductwork, piping, and wiring - is estimated to range from $55 \%$ of the total equipment cost for smaller engines to $35 \%$ for the largest CHP installations. Project and construction management is estimated to be $10 \%$ of the total equipment cost for all engines. Engineering and permitting fees are estimated to range from $10 \%$ to $8 \%$ of the total equipment cost depending on engine size. Contingency is assumed to be $5 \%$ of the total equipment cost in all cases. 
Table 4. Estimated Capital Cost for Typical Reciprocating Engine-Generators in Grid-Interconnected CHP Applications (2003)

\begin{tabular}{|c|c|c|c|c|c|}
\hline Cost Component & $\begin{array}{c}\text { System } \\
1 \\
\end{array}$ & $\begin{array}{c}\text { System } \\
2 \\
\end{array}$ & $\begin{array}{c}\text { System } \\
3 \\
\end{array}$ & $\begin{array}{c}\text { System } \\
4\end{array}$ & $\begin{array}{c}\text { System } \\
5 \\
\end{array}$ \\
\hline Nominal Capacity (kW) & 100 & 300 & 1,000 & 3,000 & 5,000 \\
\hline $\begin{array}{l}\text { Cost }(\$ / k W) \\
\text { Equipment }\end{array}$ & & & & & \\
\hline Genset Package & 500 & 350 & 370 & 440 & 450 \\
\hline Heat Recov & incl. & 180 & 90 & 65 & 40 \\
\hline Interconnect/Electrical & 250 & 150 & 100 & 75 & 65 \\
\hline Total Equipment & 750 & 680 & 560 & 580 & 555 \\
\hline Labor/Materials & 413 & 306 & 240 & 220 & 210 \\
\hline Total Process Capital & 1,163 & 986 & 800 & 800 & 765 \\
\hline $\begin{array}{l}\text { Project and Construction } \\
\text { and Management }\end{array}$ & 75 & 70 & 56 & 58 & 55 \\
\hline Engineering and Fees & 75 & 70 & 56 & 48 & 44 \\
\hline Project Contingency & 38 & 34 & 28 & 28 & 28 \\
\hline Total Plant Cost $(2003 \$ / k W)$ & $\$ 1,350$ & $\$ 1,160$ & $\$ 945$ & $\$ 935$ & $\$ 890$ \\
\hline
\end{tabular}

Source: Energy and Environmental Analysis, Inc., estimates

\subsection{Maintenance}

Maintenance costs vary with engine type, speed, size, and number of cylinders, and typically include:

- Maintenance labor

- Engine parts and materials, such as oil filters, air filters, spark plugs, gaskets, valves, piston rings, electronic components, and consumables (such as oil).

- Minor and major overhauls.

Maintenance can be done either by in-house personnel or contracted out to manufacturers, distributors, or dealers under service contracts. Full maintenance contracts (covering all recommended service) generally cost 0.7 to 2.0 cents/kWh, depending on engine size, speed, and service, as well as customer location. Many service contracts now include remote monitoring of engine performance and condition and allow predictive maintenance. Service contract rates typically are all-inclusive, including the travel time of technicians on service calls.

Recommended service is comprised of routine short-interval inspections/adjustments and periodic replacement of engine oil and filter, coolant, and spark plugs (typically at 500 to 2,000 
hours). Oil analysis to monitor engine wear is part of most preventive maintenance programs. A top-end overhaul, which entails rebuilding cylinder heads and turbochargers, is generally recommended at between 8,000 and 30,000 hours of operation (see Table 5). A major overhaul is performed after 30,000 to 72,000 hours of operation and involves piston/liner replacement, crankshaft inspection, bearings, and seals (Table 5).

Table 5. Representative Overhaul Intervals for Reciprocating Engines in Base-load Service

\begin{tabular}{|l|c|c|c|c|c|}
\hline & \multicolumn{4}{|c|}{ Time Between Overhauls - (Thousands of Operating Hours) } \\
\hline Engine Speed & $720 \mathrm{rpm}$ & $900 \mathrm{rpm}$ & $1200 \mathrm{rpm}$ & $1500 \mathrm{rpm}$ & $1800 \mathrm{rpm}$ \\
\hline Minor Overhaul & $>30$ & $15-36$ & $24-36$ & $10-20$ & $8-15$ \\
\hline Major Overhaul & $>60$ & $40-72$ & $48-60$ & $30-50$ & $30-36$ \\
\hline & & & & & \\
\hline
\end{tabular}

Source: SFA Pacific, Inc.

The maintenance costs presented in Table 6 are based on engine manufacturer estimates for service contracts consisting of routine inspections and scheduled overhauls of the enginegenerator set. Costs are based on 8,000 annual operating hours, expressed in terms of annual electricity generation.

Table 6. Typical Natural Gas-Fuel Reciprocating Engine O\&M Costs (2003)

\begin{tabular}{|l|c|c|c|c|c|}
\hline O\&M Costs 20 & System & System & System & System & System \\
& $\mathbf{1}$ & $\mathbf{2}$ & $\mathbf{3}$ & $\mathbf{4}$ & $\mathbf{5}$ \\
\hline & & & & & \\
Nominal Capacity, kW & 100 & 300 & 800 & 3,000 & 5,000 \\
Variable (service contract), \$/kWh & 0.017 & 0.012 & 0.0085 & 0.0083 & 0.0079 \\
Fixed, \$/kW-yr & 10 & 5 & 4 & 1.5 & 1.1 \\
Fixed, \$/kWh @ 8,000 hrs/yr & 0.00125 & 0.00063 & 0.0005 & 0.00019 & 0.00014 \\
& & & & & \\
\hline Total O\&M Costs, (2003 \$/kWh) & 0.018 & 0.013 & 0.009 & 0.009 & 0.008 \\
\hline
\end{tabular}

Source: Energy and Environmental Analysis, Inc., estimates

\subsection{Fuels}

Spark-ignition engines can be operated on a variety of alternative gaseous fuels, including:

- $\quad$ Liquefied petroleum gas (LPG) - propane and butane mixtures.

\footnotetext{
${ }^{20}$ Maintenance costs presented in Table 6 are based on 8,000 operating hours expressed in terms of annual electricity generation. Fixed costs are based on an interpolation of manufacturers' estimates. The variable component of the O\&M cost represents the inspections and overhaul procedures that are normally conducted by the prime mover original equipment manufacturer through a service agreement, usually based on hours of operation.
} 
- Sour gas - unprocessed natural gas as it comes directly from the gas well.

- Biogas - combustible gases produced from biological degradation of organic wastes, such as landfill gas, sewage digester gas, and animal waste digester gas.

- Industrial waste gases - flare gases and process off-gases from refineries, chemical plants, and steel mills.

- Manufactured gases - typically low- and medium-Btu gas produced by gasification or pyrolysis processes.

Factors that impact the operation of a spark-ignition engine with alternative gaseous fuels include:

- Volumetric heating value - Since engine fuel is delivered on a volume basis, fuel volume into the engine increases as heating value decreases, requiring engine derating on fuels with very low heating value. Derating is more pronounced with naturally aspirated engines, and may be compensated partly or totally by turbocharging the engine, depending on air requirements.

- Auto-ignition characteristics and detonation tendency.

- Contaminants that may impact engine component life or engine maintenance, or result in air pollutant emissions that require additional control measures.

- Hydrogen content, which may require special measures (generally if hydrogen content by volume is greater than $5 \%$ ) because of hydrogen's uniquely high flammability, flame speed, and heat-release characteristics.

Table 7 compares representative compositions of some of the alternative gaseous fuels to natural gas. Industrial waste and manufactured gases are not included in the table because their compositions vary widely, depending on their source. They typically contain significant levels of $\mathrm{H}_{2}$ and/or $\mathrm{CO}$. Other common constituents are $\mathrm{CO}_{2}$, water vapor, light hydrocarbons, $\mathrm{H}_{2} \mathrm{~S}$, and $\mathrm{SO}_{2}$. 
Table 7. Major Constituents of Gaseous Fuels

\begin{tabular}{|l|c|c|c|c|}
\hline & $\begin{array}{c}\text { Natural } \\
\text { Gas }\end{array}$ & LPG & $\begin{array}{c}\text { Digester } \\
\text { Gas }\end{array}$ & $\begin{array}{c}\text { Landfill } \\
\text { Gas }\end{array}$ \\
\hline Methane, $\mathrm{CH}_{4},(\%)$ & & & & \\
\hline Ethane, $\mathrm{C}_{2} \mathrm{H}_{6},(\%)$ & $80-97$ & 0 & $35-65$ & $40-60$ \\
\hline Propane, $\mathrm{C}_{3} \mathrm{H}_{8},(\%)$ & $3-15$ & $0-2$ & 0 & 0 \\
\hline Butane, $\mathrm{C}_{4} \mathrm{H}_{10},(\%)$ & $0-3$ & $75-97$ & 0 & 0 \\
\hline Higher $\mathrm{C}_{\mathrm{x}} \mathrm{H}_{\mathrm{x}},(\%)$ & $0-0.9$ & $0-2$ & 0 & 0 \\
\hline $\mathrm{CO}_{2},(\%)$ & $0-0.2$ & $0-20{ }^{21}$ & 0 & 0 \\
\hline $\mathrm{N}_{2},(\%)$ & $0-1.8$ & 0 & $30-40$ & $40-60$ \\
\hline $\mathrm{H}_{2},(\%)$ & $0-14$ & 0 & $1-2$ & $0-13$ \\
\hline & $0-0.1$ & 0 & 0 & 0 \\
\hline $\mathrm{HHV},(\mathrm{Btu} / \mathrm{scf})$ & & & & $350-550$ \\
\hline & $830-1,075$ & 2,500 & $300-600$ & \\
\hline
\end{tabular}

Source: SFA Pacific, Inc.; North American Combustion Handbook.

Contaminants are a concern with many waste fuels, specifically acid-gas components $\left(\mathrm{H}_{2} \mathrm{~S}\right.$, halogen acids, hydrogen cyanide); ammonia; salts and other metal-containing compounds; organic halogen-, sulfur-, nitrogen-, and silicon-containing compounds (siloxanes); and oils. In combustion, halogen and sulfur compounds form halogen acids, $\mathrm{SO}_{2}$, some $\mathrm{SO}_{3}$, and possibly $\mathrm{H}_{2} \mathrm{SO}_{4}$ emissions. If the exhaust temperature is allowed to drop below the acid dew point in the exhaust system, the acids also can corrode downstream equipment and greatly shorten lube oil life. A substantial fraction of any fuel-bound nitrogen will be oxidized into $\mathrm{NO}_{\mathrm{x}}$ in combustion. Solid particulates must be kept to very low concentrations to prevent corrosion and erosion of combustion chamber and turbocharger components. Various fuel-scrubbing, droplet-separation, and filtration steps will be required if any fuel-contaminant levels exceed manufacturers' specifications. Landfill gas, in particular, often contains chlorine compounds, sulfur compounds, organic acids, and silicon compounds, which necessitate pretreatment.

Once alternative fuels are treated and made acceptable for use in engines, their emissions performance profiles are similar to natural gas-engine performance. Specifically, the low emissions ratings of lean-burn engines usually can be maintained on alternative fuels.

$L P G$

LPG is composed primarily of propane and/or butane. Propane can be used in natural gas engines, with retarding of ignition timing and other appropriate adjustments. LPG is often used as a back-up fuel where there is a possibility of interruption in the natural gas supply. LPG is delivered as a vapor to the engine. LPG's use is limited in high-compression engines because of its relatively low octane number. In general, LPG for engines contains $95 \%$ propane by volume with an $\mathrm{HHV}$ of 2,500 Btu/scf, and with the remaining 5\% not heavier than butane. Off-spec LPG may require cooling to condense out larger volumes of butane or heavier hydrocarbons.

${ }^{21}$ High levels of heavier hydrocarbons are found in LPG derived from refinery processing 
High butane content LPG is recommended only for low compression, naturally aspirated engines. Timing must be retarded significantly to avoid detonation.

\section{Field (Well-head) Gas}

Field gas often contains more than $5 \%$ by volume of heavy ends (butane and heavier), as well as water, salts, and $\mathrm{H}_{2} \mathrm{~S}$ and usually requires some scrubbing before use in natural gas engines. Cooling may be required to reduce the concentrations of butane and heavier components. Field gas usually contains some propane and is normally used in low compression engines (both naturally aspirated and turbocharged). Ignition timing is normally retarded to avoid detonation.

\section{Biogas}

Biogases (landfill gas and digester gas) are predominantly mixtures of methane and $\mathrm{CO}_{2}$ with $\mathrm{HHV}$ in the range of 300 to $600 \mathrm{Btu} / \mathrm{scf}$. Landfill gas also contains a variety of contaminants, as discussed earlier. Biogases are produced at near-atmospheric pressure, so they must be compressed for delivery to the engine. After compression is completed, cooling and scrubbing (or filtration) are required to remove compressor oil, condensate, and particulates that may have been entrained in the original gas. Scrubbing with a caustic solution may be required if acid gases are present. Because of the additional requirements for raw gas treatment, biogas-powered engine facilities are more costly to build and operate than natural gas-based systems.

\section{Industrial Waste Gases}

Industrial waste gases that are common reciprocating engine fuels include refinery gases and process off-gases. Refinery gases typically contain components such as $\mathrm{H}_{2}, \mathrm{CO}$, light hydrocarbons, $\mathrm{H}_{2} \mathrm{~S}$, and ammonia, as well as $\mathrm{CO}_{2}$ and $\mathrm{N}_{2}$. Process off-gases may have a wide variety of compositions. Generally, waste gases are medium- to low-Btu content. Medium-Btu gases generally can be used without significant engine derating, but derating is usually necessary with low-Btu gases.

Depending on their origin and contaminants, industrial gases may require pretreatment comparable to that applied to raw landfill gas. Particulates (e.g., catalyst dust), oils, condensable gases, water, hydrocarbons heavier than propane, and acid gases (hydrogen sulfide and carbon dioxide) may all need to be removed from the gas to make it suitable for reciprocating engines. Process off-gases are usually available at pressures of several atmospheres or higher, which are generally sufficient for use in an on-site or nearby reciprocating engine facility without further compression.

\subsection{Availability and Life}

Although reciprocating engines are generally perceived as maintenance-intensive, they can provide high levels of availability, even in high-load-factor applications. While natural gas engine availabilities vary with engine type, speed, and fuel quality, the major engine manufacturers estimate engine availability to be $96 \%$ for continuous duty applications. Improvements in diagnostics and controls are expected to increase availability to $97.5 \%$ over the planning horizon of this report (2030). The manufacturers also estimate that the forced outage to scheduled outage rate ratio is currently 2 to 1 . 
The use of multiple units or back-up units at a site can further increase the availability and reliability of the overall cogeneration facility. Some engine manufacturers offer engine exchange programs or other maintenance options that increase the ability to promptly deliver and install replacement units on short notice if needed.

The service life of natural gas reciprocating engine systems is estimated to be 20 years - if they receive several minor and at least one major overhaul during that time. Costs of these overhauls are included in the nonfuel maintenance estimates presented earlier in the report. The economic life of natural gas-engine systems is typically assumed to be 20 years.

\subsection{Emission Characteristics}

Exhaust emissions are the primary environmental concern with reciprocating engines. The primary pollutants are oxides of nitrogen $\left(\mathrm{NO}_{\mathrm{x}}\right)$, carbon monoxide $(\mathrm{CO})$, and volatile organic compounds (VOCs - unburned or partially burned non-methane hydrocarbons). Concentrations of other pollutants, such as oxides of sulfur $\left(\mathrm{SO}_{\mathrm{x}}\right)$ and particulate matter $(\mathrm{PM})$ are primarily dependent on the fuel used. Emissions of sulfur compounds, primarily $\mathrm{SO}_{2}$, are directly related to the sulfur content of the fuel. Engines operating on natural gas or distillate oil, which has been desulfurized in the refinery, emit insignificant levels of $\mathrm{SO}_{x}$. In general, $\mathrm{SO}_{\mathrm{x}}$ emissions are an issue only in larger, lower-speed diesel engines firing heavy oils. Particulate matter (PM) can be an important pollutant for engines that use liquid fuels. Ash and metallic additives in the fuel and lubricating oil contribute to PM concentrations in the exhaust.

\subsection{Control Options}

$\mathrm{NO}_{\mathrm{x}}$ emissions are usually the primary concern with natural gas engines and are a mixture of (mostly) $\mathrm{NO}$ and $\mathrm{NO}_{2}$ in variable proportions. Measurements of $\mathrm{NO}_{\mathrm{x}}$ are reported as parts per million by volume, in which both species count equally (e.g., ppmv at $15 \% \mathrm{O}_{2}$, dry). Other common units for reporting $\mathrm{NO}_{\mathrm{x}}$ in reciprocating engines are specific output-based emission factors, such as $\mathrm{g} / \mathrm{hp}-\mathrm{hr}$ and $\mathrm{g} / \mathrm{kW}-\mathrm{hr}$, or as total output rates, such as $\mathrm{lb} / \mathrm{hr}$. Among the engine options without exhaust after-treatment, lean-burn natural gas engines produce the lowest $\mathrm{NO}_{\mathrm{x}}$ emissions; and diesel engines produce the highest (Table 8).

\section{Table 8. Representative $\mathrm{NO}_{\mathrm{x}}$ Emissions from Reciprocating Engines (Without Add-on Controls)}

\begin{tabular}{|l|c|c|c|c|}
\hline Engines & $\begin{array}{c}\text { Efficiency } \\
\text { Range } \\
\text { (\%, LHV) }\end{array}$ & Fuel & $\begin{array}{c}\text { NO } \\
\text { (ppmv) }\end{array}$ & $\begin{array}{c}\text { NO } \\
\text { (g/bhp-hr) }\end{array}$ \\
\hline $\begin{array}{l}\text { Diesel Engines (high-speed } \\
\text { and medium-speed) }\end{array}$ & 37 to 44 & Distillate & $450-1,350$ & $5-14$ \\
\hline $\begin{array}{l}\text { Diesel Engines (high-speed } \\
\text { and medium-speed) }\end{array}$ & 42 to 48 & Heavy Oil & $900-1,800$ & $9-15$ \\
\hline $\begin{array}{l}\text { Lean-Burn, Spark-Ignition } \\
\text { Engine }\end{array}$ & 35 to 42 & Natural Gas & $45-150$ & $0.5-2$ \\
\hline
\end{tabular}

Source: Energy and Environmental Analysis, Inc., estimates 
The control of peak flame temperature through lean-burn conditions has been the primary emissions combustion design approach to controlling $\mathrm{NO}_{\mathrm{x}}$ formation in gas engines. Diesel engines have higher combustion temperatures and produce more $\mathrm{NO}_{\mathrm{x}}$ than lean-burn gas engines, even though the overall diesel engine air/fuel ratio may be very lean. There are three reasons for this: (1) heterogeneous near-stoichiometric combustion of fuel droplets, (2) the higher adiabatic flame temperature of distillate fuel, and (3) fuel-bound nitrogen (nitrogen that is part of an organic component of the fuel). The diesel fuel is atomized as it is injected and dispersed in the combustion chamber. Combustion largely occurs at near-stoichiometric conditions at the air-droplet and air-fuel vapor interfaces, resulting in maximum temperatures and higher $\mathrm{NO}_{\mathrm{x}}$ formation. In contrast, the lean-premixed homogeneous combustion in lean-burn gas engines results in lower peak combustion temperatures and lower $\mathrm{NO}_{\mathrm{x}}$ production.

For any engine there are generally trade-offs between low $\mathrm{NO}_{\mathrm{x}}$ emissions and high efficiency. There are also trade-offs between low $\mathrm{NO}_{\mathrm{x}}$ emissions and emissions of the products of incomplete combustion (CO and unburned hydrocarbons). There are three main approaches to these trade-offs that may come into play, depending on regulations and economics. One approach is to control for lowest $\mathrm{NO}_{\mathrm{x}}$ accepting a fuel efficiency penalty and possibly higher $\mathrm{CO}$ and hydrocarbon emissions. A second option is finding an optimal balance between emissions and efficiency. A third option is to design for highest efficiency and use post-combustion exhaust treatment to control emissions if required for permitting purposes.

$\mathrm{NO}_{\mathrm{x}}$ control has been the primary focus of emission-control research and development in natural gas engines in recent years. The following provides a description of the most prominent emission-control approaches.

\section{Combustion Process Emissions Control}

Control of combustion temperature has been the principal focus of combustion process control in gas engines. Combustion control involves tradeoffs. High temperatures favor complete combustion of the fuel and low residual unburned hydrocarbons and $\mathrm{CO}$, but high temperatures also promote $\mathrm{NO}_{\mathrm{x}}$ formation. Very lean combustion dilutes the combustion process and reduces combustion temperatures and $\mathrm{NO}_{\mathrm{x}}$ formation, and it allows for higher compression ratios and mean effective firing pressures, resulting in higher efficiency. However, if the mixture is too lean, misfiring and incomplete combustion occur, increasing $\mathrm{CO}$ and VOC emissions.

Lean-burn engine technology was developed during the 1980s as a direct response to the need for low-emission gas engines. Thermal $\mathrm{NO}_{\mathrm{x}}$ formation is a function of both flame temperature and residence time. Lean-burn developments reduced combustion temperature in the cylinder using lean fuel/air mixtures. Lean combustion decreases the fuel/air ratio in the zones where $\mathrm{NO}_{\mathrm{x}}$ is produced, so that peak flame temperature is lower than the stoichiometric adiabatic flame temperature, thereby suppressing thermal $\mathrm{NO}_{\mathrm{x}}$ formation. More uniform mixing of fuel and air reduces the incidence of the local peaks in temperature that contribute heavily to NOx emissions. Many lean-burn gas engines introduce the fuel prior to the engine turbocharger, which provides a well-mixed, lean fuel-air supply to the combustion chambers. Lean-burn engines generally use $50 \%$ to $100 \%$ excess air (above stoichiometric). Typical $\mathrm{NO}_{\mathrm{x}}$ emission rates for lean-burn natural gas engines are 0.5 to $2.0 \mathrm{~g} / \mathrm{bhp}-\mathrm{hr}$. 
As discussed above, an added performance advantage of lean-burn operation is higher output and higher efficiency resulting from the higher compression ratios. Optimal lean-burn operation requires sophisticated engine controls to ensure that combustion remains stable and $\mathrm{NO}_{\mathrm{x}}$ reduction is maximized while minimizing emissions of CO and VOCs. Table 9 shows data for a large lean-burn natural gas engine and illustrates the tradeoffs between $\mathrm{NO}_{\mathrm{x}}$ emissions control levels and efficiency. To obtain the lowest achievable $\mathrm{NO}_{\mathrm{x}}$ levels (45 to $50 \mathrm{ppmv}$ ), 1.3 efficiency percentage points are lost.

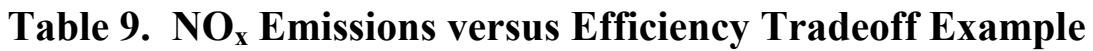

\begin{tabular}{|c|c|c|}
\hline Engine Characteristics & Low NO & High Efficiency \\
\hline Capacity (MW) & 5.2 & 5.2 \\
\hline Speed (rpm) & 720 & 720 \\
\hline Efficiency, LHV (\%) & 40.7 & 42.0 \\
\hline Emissions: & & \\
\hline $\begin{aligned} \mathrm{NO}_{\mathrm{x}} & (\mathrm{g} / \mathrm{bhp}-\mathrm{hr}) \\
& \left(\mathrm{ppmv} @ 15 \% \mathrm{O}_{2}\right)\end{aligned}$ & $\begin{array}{l}0.5 \\
46\end{array}$ & $\begin{array}{l}1.1 \\
92\end{array}$ \\
\hline $\begin{array}{ll}\mathrm{CO} & (\mathrm{g} / \mathrm{bhp}-\mathrm{hr}) \\
& \left(\mathrm{ppmv} @ 15 \% \mathrm{O}_{2}\right)\end{array}$ & $\begin{array}{l}2.5 \\
361\end{array}$ & $\begin{array}{l}1.5 \\
227\end{array}$ \\
\hline $\begin{aligned} \text { VOC } & (\mathrm{g} / \mathrm{bhp}-\mathrm{hr}) \\
& \left(\mathrm{ppmv} @ 15 \% \mathrm{O}_{2}\right)\end{aligned}$ & $\begin{array}{l}0.7 \\
61\end{array}$ & $\begin{array}{l}0.5 \\
39\end{array}$ \\
\hline
\end{tabular}

Combustion temperature also can be controlled, to some extent, in reciprocating engines by one or more of the following techniques:

- Retarding ignition timing or fuel injection, thereby reducing peak cylinder pressure and temperature

- Diluting the fuel-air mixture with recirculated exhaust gases (EGR), which displace some of the combustion air and contain water vapor that has a relatively high heat capacity and absorbs some of the heat of combustion

- Introducing water by direct injection or via fuel oil emulsification - evaporation of the water cools the fuel-air mixture charge

- Reducing the inlet air temperature with a heat exchanger after the turbocharger, or by inlet air humidification

- Modifying valve timing, compression ratio, turbocharging, and combustion chamber configuration. 
Water injection and EGR are widely known techniques for diesel engines, and they reduce $\mathrm{NO}_{\mathrm{x}}$ emissions by $30 \%$ to $60 \%$ from uncontrolled levels. The incorporation of water injection and enhanced EGR into lean-burn gas engines is the focus of ongoing R\&D by several engine manufacturers and are both being pursued as potential options in the Department of Energy's Advanced Reciprocating Engine Systems (ARES) program.

\section{Post-Combustion Emissions Control}

There are several types of catalytic exhaust gas treatment processes that are applicable to reciprocating engines:

Three-Way Catalyst - The catalytic three-way conversion process (TWC) is the basic automotive catalytic converter process that reduces concentrations of all three major criteria pollutants $\mathrm{NO}_{\mathrm{x}}, \mathrm{CO}$, and VOCs. The TWC process is also called nonselective catalytic reduction (NSCR). $\mathrm{NO}_{\mathrm{x}}$ and $\mathrm{CO}$ reductions are generally greater than $90 \%$, and VOCs are reduced approximately $80 \%$ in a new, properly controlled TWC system. Conversion of $\mathrm{NO}_{\mathrm{x}}$ to $\mathrm{N}_{2}$ and $\mathrm{CO}$ and hydrocarbons to $\mathrm{CO}_{2}$ and $\mathrm{H}_{2} \mathrm{O}$ will not take place in atmospheres with excess oxygen (the exhaust gas must contain less than $0.5 \% \mathrm{O}_{2}$ ). Therefore, TWCs are only effective with stoichiometric or rich-burning engines. Typical "engine out" (i.e., untreated exhaust) $\mathrm{NO}_{\mathrm{x}}$ emission factors for rich-burn engines are 10 to $15 \mathrm{~g} / \mathrm{bhp}-\mathrm{hr}$. $\mathrm{NO}_{\mathrm{x}}$ emissions with TWC control can be as low as $0.15 \mathrm{~g} / \mathrm{bhp}-\mathrm{hr}$; however, catalyst performance may deteriorate over time. The extent of deterioration depends on the fuel used, oil consumption, and maintenance practices.

Stoichiometric and rich-burn engines have significantly lower efficiency than lean-burn engines. Periodic replacement of the catalysts in TWC systems also increases maintenance costs by as much as $25 \%$. TWCs use noble metal catalysts that are vulnerable to poisoning and masking (fouling), which limits their use to engines operated with clean fuels, such as natural gas or unleaded gasoline. Also, the engines must use lubricants that do not generate catalyst-poisoning compounds and have low concentrations of metal-based additives. Unburned fuel, unburned lube oil, and particulate matter also can foul the catalyst. TWC technology is not applicable to lean-burn gas engines or diesels.

Selective Catalytic Reduction (SCR) - This technology selectively reduces $\mathrm{NO}_{\mathrm{x}}$ to $\mathrm{N}_{2}$ in the presence of a reducing agent. $\mathrm{NO}_{\mathrm{x}}$ reductions of $80 \%$ to more than $90 \%$ are achievable with SCR. Higher reductions are possible with the use of more catalyst, increased reducing agent feed rates, or utilizing closed loop feedback systems - or a combination of these three techniques. The two commercially available reducing agents are ammonia $\left(\mathrm{NH}_{3}\right.$ in anhydrous liquid form or aqueous solution) and aqueous urea. Urea decomposes in the hot exhaust gas and SCR reactor, releasing ammonia. Approximately 0.9 to 1.0 moles of ammonia are required per mole of $\mathrm{NO}_{\mathrm{x}}$ at the $\mathrm{SCR}$ reactor inlet in order to achieve $80 \%$ to $90 \% \mathrm{NO}_{\mathrm{x}}$ reduction.

SCR systems add significant installation, operation, and maintenance costs and can severely impact the economic feasibility of small engine projects. SCR requires on-site storage of urea or ammonia, a hazardous chemical. In addition ammonia can "slip" through the process unreacted, contributing to environmental health concerns. 
Oxidation Catalysts - Oxidation catalysts generally are precious metal compounds that promote oxidation of $\mathrm{CO}$ and hydrocarbons to $\mathrm{CO}_{2}$ and $\mathrm{H}_{2} \mathrm{O}$ in the presence of excess $\mathrm{O}_{2}$. $\mathrm{CO}$ and NMHC conversion levels of $98 \%$ to $99 \%$ are achievable. Methane conversion may approach $60 \%$ to $70 \%$. Oxidation catalysts are now widely used with all types of engines, including diesel engines. They are being used increasingly with lean-burn gas engines to reduce their relatively high $\mathrm{CO}$ and VOC emissions.

Lean-NO $\mathrm{O}_{x}$ Catalysts - Lean-NO $\mathrm{NO}_{\mathrm{x}}$ catalysts utilize a hydrocarbon (usually the engine fuel) injected upstream of the catalyst to react with and reduce $\mathrm{NO}_{\mathrm{x}}$. While this technique is still under development, it appears that $\mathrm{NO}_{\mathrm{x}}$ reduction of $80 \%$ and both $\mathrm{CO}$ and $\mathrm{NMHC}$ emissions reductions of $60 \%$ may be possible. Long-term testing, however, has raised issues about sustained performance of the catalysts. Current lean- $\mathrm{NO}_{\mathrm{x}}$ catalysts are prone to poisoning by both lube oil and fuel sulfur. Both precious-metal and base-metal catalysts are highly intolerant of sulfur. This technology can significantly increase fuel use - the high $\mathrm{NO}_{\mathrm{x}}$ output of diesel engines would require approximately $3 \%$ of the engine fuel consumption for the catalyst system.

\subsection{System Emissions}

Table 10 shows typical emissions for each of the five reciprocating engine systems. The emissions presented are based on natural gas engine exhaust emissions with no exhaust aftertreatment. System 1, the $100 \mathrm{~kW}$ engine, is a high-speed, rich-burn engine.

\section{Table 10. Reciprocating Engine Emissions Characteristics (Without Exhaust-Control Options*)}

\begin{tabular}{|l|c|c|c|c|c|}
\hline Emissions Characteristics $^{22}$ & System & System & System & System & System \\
& $\mathbf{1}$ & $\mathbf{2}$ & $\mathbf{3}$ & $\mathbf{4}$ & $\mathbf{5}$ \\
\hline Nominal Capacity, $(\mathrm{kW})$ & 100 & 300 & 1,000 & 3,000 & 5,000 \\
\hline Electrical Efficiency, (\%) & 30 & 31 & 34 & 35 & 37 \\
\hline Engine Combustion & Rich & Lean & Lean & Lean & Lean \\
\hline & & & & & \\
\hline $\mathrm{NO}_{\mathrm{x},(\mathrm{g} / \mathrm{bhp}-\mathrm{hr})}$ & 15 & 2 & 1 & 0.7 & 0.5 \\
\hline $\mathrm{NO}_{\mathrm{x},\left(\mathrm{ppmv} @, 15 \% \mathrm{O}_{2}\right)}$ & 1,100 & 150 & 80 & 60 & 40 \\
\hline $\mathrm{NO}_{\mathrm{x}},(\mathrm{lb} / \mathrm{MWh})$ & 46 & 6.2 & 3.1 & 2.2 & 1.6 \\
\hline $\mathrm{CO},(\mathrm{g} / \mathrm{bhp}-\mathrm{hr})$ & 12 & 2 & 2 & 2.5 & 2.4 \\
\hline $\mathrm{CO},(\mathrm{lb} / \mathrm{MWh})$ & 37 & 6.2 & 6.2 & 7.8 & 7.4 \\
\hline $\mathrm{VOC},(\mathrm{g} / \mathrm{bhp}-\mathrm{hr})$ & 0.7 & 1.0 & 1.0 & 1.3 & 0.5 \\
\hline $\mathrm{VOC},(\mathrm{lb} / \mathrm{MWh})$ & 2.2 & 3.1 & 3.1 & 4 & 1.6 \\
\hline $\mathrm{CO},(\mathrm{lb} / \mathrm{MWh})$ & 1,345 & 1,283 & 1,175 & 1,135 & 1,078 \\
\hline
\end{tabular}

For typical natural gas-fueled systems commercially available in 2003. Emissions estimates are for untreated engine exhaust (no TWC, SCR, or other exhaust clean-up). Estimates are based on manufacturers' specifications.

22 Characteristics for "typical" commercially available natural gas engine gensets. Data based on: MAN $150 \mathrm{~kW}-$ 100 kW; Cummins GSK19G - 300 kW; Cummins QSV91G - 1 MW; Caterpillar G3616 LE - 3 MW; Wartsila $18 \mathrm{~V} 34 \mathrm{SG}-5 \mathrm{MW}$ 
Use of a TWC system would reduce $\mathrm{NO}_{\mathrm{x}}$ emissions to $0.15 \mathrm{~g} / \mathrm{bhp}-\mathrm{hr}$, $\mathrm{CO}$ emissions to 0.6 $\mathrm{g} / \mathrm{bhp}-\mathrm{hr}$, and VOC emissions to $0.15 \mathrm{~g} / \mathrm{bhp}-\mathrm{hr}$. Systems 2 through 5 are all lean-burn engines optimized for low emissions. Use of an oxidation catalyst could reduce $\mathrm{CO}$ and VOC emissions from these engines by $98 \%$ to $99 \%$.

With current commercial technology, highest efficiency and lowest $\mathrm{NO}_{\mathrm{x}}$ are not achieved simultaneously. Therefore many manufacturers of lean-burn gas engines offer different versions of an engine - a low $\mathrm{NO}_{\mathrm{x}}$ version and a high-efficiency version - based on different tuning of the engine controls and ignition timing. Achieving highest efficiency operation results in conditions that generally produce twice as much $\mathrm{NO}_{\mathrm{x}}$ as low $\mathrm{NO}_{\mathrm{x}}$ versions (e.g., $1.0 \mathrm{~g} / \mathrm{bhp}-\mathrm{hr}$ versus 0.5 $\mathrm{g} / \mathrm{bhp}-\mathrm{hr}$ ). Achieving the lowest $\mathrm{NO}_{\mathrm{x}}$ typically entails sacrifice of 1 to 2 points in efficiency (e.g., $36 \%$ versus $38 \%$ ). In addition, $\mathrm{CO}$ and $\mathrm{VOC}$ emissions are generally higher for engines optimized for minimum $\mathrm{NO}_{\mathrm{x}}$.

\subsection{Key Technology Objectives}

Manufacturers of stationary engines have pursued significant R\&D, driven by competition (both among themselves and from other prime movers) and by environmental pressures. Efforts have focused on reducing emissions $\left(\mathrm{NO}_{\mathrm{x}}\right.$ for gas engines, $\mathrm{NO}_{\mathrm{x}}$ and particulates for diesels), increasing engine efficiency and power, reducing engine costs, and extending maintenance intervals. The pace of technology advances in stationary engines has accelerated with the adoption of improved combustion techniques, and controls and sensor technologies developed for automotive and truck engines, as well as the adoption of increasingly stringent emissions regulations.

The primary research and development goals of natural gas-engine manufacturers include the following:

- Reduced environmental impact - application of advanced combustion technology and improved sensors and controls to attain emissions levels comparable to gas turbines (i.e., 10 ppmv $\mathrm{NO}_{\mathrm{x}}$ on a $15 \% \mathrm{O}_{2}$ basis) without sacrificing fuel efficiency and without exhaust gas treatment, or alternatively, low-cost exhaust gas treatment for final control of $\mathrm{NO}_{\mathrm{x}}$, $\mathrm{CO}$ and VOCs.

- Lower initial engine costs - increases in power densities that result in lower $\$ / \mathrm{kW}$ costs

- Lower operation and maintenance costs - reducing engine wear and complexity, simplifying required service, extending service intervals, and minimizing operator/technician attention

- Longer engine life - extending the time between minor and major overhauls

- Higher efficiencies - application of high-temperature materials, engine sensors and controls, and improved combustion practices 
- Higher reliability and availability

- Increase heat recovery for CHP applications through utilization of low temperature cooling circuits and improved thermal management.

Upgrading current natural gas-engine designs and optimizing for emissions and performance are challenging tasks because of the complex interrelationships among combustion process variables, operating cycle parameters, engine dynamics, and mechanical designs. The primary technical issues include increasing BMEP and engine speed, improved engine controls, improved materials, improved ignition systems, and exhaust gas treatment.

\section{Increasing BMEP and Engine Speed}

Increasing BMEP or engine speed increases power output and power density. However, increasing either parameter taxes the materials and strength of the engine and affects friction and lubrication demands, wear, efficiency, cooling load, and emissions.

Raising the BMEP increases the peak temperature within the cylinder, unless offset by techniques to keep temperature under control. Temperature can be controlled by leaning out the fuel-air mixture further, or by using exhaust gas recirculation or water injection. Hotter combustion generally provides more complete combustion of the fuel and higher efficiency, but it increases $\mathrm{NO}_{\mathrm{x}}$ emissions, reduces spark plug life, may shorten the life of other combustion chamber components, and decreases effectiveness of lubricants.

Increasing engine speed is often used to increase the output of an existing engine design. The ability to uprate an existing engine depends on how conservatively the engine block and drive train initially were designed. Many engines of a particular bore and stroke are already optimized for a selected speed. Operating at or near their maximum design speeds on a continuous basis increases engine wear and maintenance and, in some cases, may increase the risk of engine damage. An engine's speed cannot be increased beyond a certain dynamic limit without requiring extensive redesign.

\section{Improved Engine Controls}

As the air-fuel ratio and BMEP are increased in high-performance, lean-burn engines, the operating region between detonation and misfire is narrowed, so that precise control of fuel-air ratio and ignition timing for each cylinder at the optimum combustion point is essential. Gas engines operating in the pinch zone between detonation and lean misfiring - where high efficiency and low emissions are possible - may be at higher risk of damage due to failure of a critical sensor or control component or shifts in fuel quality (specific heat content). Advanced electronics enable the individual cylinder ignition control that is essential to operate gas engines in the pinch zone. 
Advances in this area include improved fuel-injection timing and injection-rate shaping, improved knock (detonation) sensors, pressure sensors for monitoring peak pressures and BMEP in individual cylinders, improved ignition systems, and programmable logic control of the engine for optimal performance under a wide range of conditions, including humidity compensation and knock detection. Many of these advances were achieved by incorporating new technology from automotive and truck-engine designs. Such advances include model-based controls, which are gaining attention for the design of advanced engine control systems and promise highly robust control strategies that incorporate a high degree of subsystem integration for optimum emissions and efficiency performance.

\section{Improved Materials}

Work is ongoing on new and improved alloys, ceramics, and composite materials for components (cylinder liners, piston rings, valves, and valve seats) to support the more demanding engine operating conditions associated with increased output and to reduce component wear and extend service intervals. Several major engine manufacturers have been testing silicon nitride valve seats for a number of years. New materials and thermal barriers also are being incorporated to increase efficiency by reducing energy losses in exhaust ports and manifolds, and in reducing in-cylinder heat loss.

\section{Improved Ignition Systems}

Improving spark plug materials and life remains a major priority of engine manufacturers. As an example, noble metal spark plugs that are under development have the potential to significantly extend spark plug life. Electronic ignition allows for improved combustion control. However, the technologies now available are the result of development efforts for high-speed automotive engine applications. These technologies are not necessarily designed for the load and pressure effects that high-speed (1,200 to 1,800 rpm), stationary engines require. Higher compression ratios and leaner operation will further increase the need for improved ignition systems. Research to understand the ignition system demands and ignition system dynamics in mediumspeed natural gas engines is needed to achieve optimized ignition systems that will meet customer expectations for component life and maintenance costs.

\section{Exhaust Gas Treatment}

While engine manufacturers continue to improve emissions from gas engines through combustion control, work also continues on improving the performance and reducing the costs of exhaust gas after-treatment options. The primary focus for gas engines is the development of lean- $\mathrm{NO}_{\mathrm{x}}$ catalysts. As discussed earlier, lean- $\mathrm{NO}_{\mathrm{x}}$ catalysts utilize a hydrocarbon reducing agent (usually the engine fuel) injected upstream of the catalyst to reduce $\mathrm{NO}_{\mathrm{x}}$. These catalysts are still under development, but it appears that $\mathrm{NO}_{\mathrm{x}}$ reduction of $80 \%$ and both $\mathrm{CO}$ and $\mathrm{NMHC}$ emissions reductions of $60 \%$ may be possible. Long-term testing, however, has raised issues about sustained performance of the catalysts. Current lean- $\mathrm{NO}_{\mathrm{x}}$ catalysts can be poisoned by both lube oil and fuel sulfur. Both precious-metal and base-metal catalysts are highly intolerant of sulfur. 
Another emission-control strategy under investigation involves the use of increased exhaust gas recirculation (EGR) and a three-way catalyst for $\mathrm{NO}_{\mathrm{x}}$ reduction ${ }^{23}$. As described in Section 5 of this chapter, three-way catalysts efficiently reduce $\mathrm{NO}_{\mathrm{x}}$, but the overall exhaust composition must be within $0.5 \%$ of stoichiometric conditions. This requirement prevents the use of air as a diluent, as is used in current lean-burn engines. The use of EGR to dilute the fuel-air charge would be similar in principle to lean burn, with recycled exhaust taking the place of excess air to dilute the intake fuel charge and reduce cylinder temperatures and hot spots. The advantage of EGR is that a three-way catalyst could then be used to reduce the $\mathrm{NO}_{\mathrm{x}}$ because the exhaust mixture would contain little oxygen. This approach, however, would create a new set of necessary tradeoffs. While dilution with EGR can reduce $\mathrm{NO}_{\mathrm{x}}$, there is a limit to the amount of dilution that can be used - analogous to the lean-burn engine at the lean limit. The amount of acceptable EGR dilution is usually less than can be achieved with air, so the $\mathrm{NO}_{\mathrm{x}}$ emissions produced by the engine are higher; but the emissions could be reduced through the use of the three-way catalysts, which are a simpler and more cost-effective post-combustion treatment option than selective catalytic reduction.

\section{Advanced Reciprocating Engine Systems (ARES) Program}

A national development program to increase the efficiency and decrease the emissions of stationary gas engines was initiated by the U.S. Department of Energy and a consortium of engine manufacturers in 2001. Target goals include 50\% electrical efficiency (LHV) and $\mathrm{NO}_{\mathrm{x}}$ emissions as low as $0.1 \mathrm{~g} / \mathrm{bhp}-\mathrm{hr}$. The ARES program is investigating various approaches to increase BMEP, alternative ignition techniques (including micropilot dual fuel), extension of lean combustion limits, knock mitigation with water injection, exhaust gas after-treatment, and a variety of supporting efforts in combustion chamber design, friction reduction techniques, heat loss reduction, and combustion modeling/simulation.

Gas engines will continue to improve as R\&D advances are incorporated into new products. With the anticipated advanced techniques, materials, and technologies, further improvements in power densities, efficiencies, emissions, durability, and reliability are expected. However, evolving environmental regulations and their potential to add significant costs to stationary engine applications remain as major risks to the competitiveness of stationary engines.

\subsection{Advanced Technology Projections}

The cost and performance of industrial gas engines have continually improved. Efficiency has increased, capital costs have fallen, and emissions have declined. Significant private- and public-sector investment should result in additional incremental, and potentially evolutionary improvements in the technology during the next 30 years.

There are several classes of improvements in gas engines that will increase their attractiveness for on-site and distributed power generation:

\footnotetext{
${ }^{23}$ John T. Kubish, "Evolution of an Engine”. SwRI Fall/Winter 2000 Technology Today, Southwest Research Institute, San Antonio, Texas
} 
$\square$ Efficiencies will improve through increasing BMEP and potentially with the use of thermal barrier coatings. Improved controls will allow very lean combustion that optimizes both efficiency and emissions. Increased BMEP and engine speed will increase power output and correspondingly decrease cost per $\mathrm{kW}$ of the larger engines.

$\square$ Emissions will be improved through a combination of combustion improvements and advanced exhaust gas treatment.

$\square$ Maintenance costs will be reduced as engine life is extended and maintenance intervals lengthened through the use of ceramics and other advanced materials, improved lubricants, and improved engine components.

While there will be much effort to improve high efficiency, lean-burn engines, nearer-term initiatives will result in more efficient, more durable stoichiometric engines in the smaller size ranges.

The smaller stationary engines will benefit from the adoption of performance and controls improvements developed for the transportation markets.

More effective packaging and integration of systems and controls will reduce the cost of basic engine packages by $10 \%$ to $25 \%$. On-site cost of installation will be reduced by greater standardization of system design and auxiliary components. A modular approach with greater factory assembly is expected to greatly reduce site costs, particularly for smaller systems.

$\square$ The cost of installing CHP plants will decline, based on states adopting streamlined siting, interconnection, and permitting procedures that allow for greater standardization of CHP components and packages. Electric utility interconnection costs are projected to be reduced by $50 \%$ for systems smaller than $500 \mathrm{~kW}$ and by $20 \%$ for systems larger than $3 \mathrm{MW}$.

Engineering, project and construction management, and project contingencies will decline over time in proportion to the reduction in equipment costs and the need for custom integration of system components.

Estimates of the future performance of the five gas engine CHP systems previously used as representative systems are shown in Table 11. The out-year performance projections for 2005, 2010, 2020, and 2030 are based on the technology and learning curve advances contained in the list above. 


\section{Table 11. Current and Advanced Reciprocating Engine System Characteristics ${ }^{24}$}

\begin{tabular}{|c|c|c|c|c|c|}
\hline \multicolumn{6}{|c|}{$\begin{array}{l}\text { Cost and Performance Projections, } \\
100 \mathrm{~kW} \text { Gas Engine CHP System - Rich Burn } \\
\text { with Three-Way Catalyst }\end{array}$} \\
\hline Year & Current & 2005 & 2010 & 2020 & 2030 \\
\hline System Size, kW & 100 & 100 & 100 & 100 & 100 \\
\hline Total Installed Cost $(2003 \$ / \mathrm{kW})$ & 1,350 & 1,300 & 1,100 & 1,000 & 970 \\
\hline O\&M Costs $(2003 \$ / \mathrm{kWh})$ & 0.018 & 0.015 & 0.013 & 0.012 & 0.01 \\
\hline Electrical Heat Rate (Btu/kWh) & 11,500 & 11,187 & 10,832 & 10,500 & 10,035 \\
\hline Electric Efficiency (\%) & 30 & 31 & 32 & 33 & 34 \\
\hline Fuel Input (MMBtu/hr) & 1.15 & 1.12 & 1.08 & 1.05 & 1.0 \\
\hline \multicolumn{6}{|l|}{ CHP Characteristics } \\
\hline \begin{tabular}{|l} 
Total CHP Efficiency (\%) \\
\end{tabular} & 78 & 78 & 79 & 79 & 80 \\
\hline Heat Output (MMBtu/hr) & 0.56 & 0.53 & 0.51 & 0.49 & 0.46 \\
\hline Heat/Fuel Ratio & 0.49 & 0.47 & 0.47 & 0.47 & 0.46 \\
\hline Power/Heat Ratio & 0.61 & 0.64 & 0.67 & 0.70 & 0.74 \\
\hline Net Heat Rate (Btu/kWh) & 4,500 & 4,562 & 4,457 & 4,373 & 4,285 \\
\hline \multicolumn{6}{|c|}{ Emissions Characteristics - w/three-way catalyst } \\
\hline $\mathrm{NO}_{\mathrm{x}}(\mathrm{g} / \mathrm{bhp}-\mathrm{hr})$ & 0.15 & 0.15 & 0.1 & 0.1 & 0.1 \\
\hline CO (g/bhp-hr) & 0.60 & 0.60 & 0.50 & 0.3 & 0.1 \\
\hline VOC (g/bhp-hr) & 0.15 & 0.15 & 0.10 & 0.10 & 0.10 \\
\hline $\mathrm{CO}_{2}(\mathrm{lb} / \mathrm{MWh})$ & 1,345 & 1,308 & 1,267 & 1,228 & 1,174 \\
\hline
\end{tabular}

${ }^{24}$ Estimates are based on: MAN $150 \mathrm{~kW}$ (stoichiometric with three-way catalyst system) - $100 \mathrm{~kW}$; Cummins GSK19G - 300 kW; Cummins QSV91G - 1 MW; Caterpillar G3616 LE - 3 MW; Wartsila 18V34SG - 5 MW 


\section{Table 11 (cont'd.) Current and Advanced Reciprocating Engine System Characteristics}

\begin{tabular}{|c|c|c|c|c|c|}
\hline \multicolumn{6}{|c|}{$\begin{array}{l}\text { Cost and Performance Projections, } \\
300 \text { kW Gas Engine CHP System - Lean Burn }\end{array}$} \\
\hline Year & Current & 2005 & 2010 & 2020 & 2030 \\
\hline Total Installed Cost $(2003 \$ / \mathrm{kW})$ & 1,160 & 1,130 & 1,030 & 930 & 900 \\
\hline O\&M Costs $(2003 \$ / \mathrm{kWh})$ & 0.013 & 0.012 & 0.012 & 0.010 & 0.010 \\
\hline Electrical Heat Rate (Btu/kWh) & 10,967 & 10,832 & 10,498 & 10,185 & 9,749 \\
\hline Electric Efficiency (\%) & 31 & 32 & 33 & 34 & 35 \\
\hline Fuel Input (MMBtu/hr) & 3.3 & 3.25 & 3.15 & 3.06 & 2.92 \\
\hline \multicolumn{6}{|l|}{ CHP Characteristics } \\
\hline Total CHP Efficiency (\%) & 77 & 77 & 77 & 78 & 78 \\
\hline Heat Output (MMBtu/hr) & 1.52 & 1.48 & 1.40 & 1.35 & 1.25 \\
\hline Heat/Fuel Ratio & 0.46 & 0.46 & 0.44 & 0.44 & 0.43 \\
\hline Power/Heat Ratio & 0.67 & 0.69 & 0.73 & 0.76 & 0.82 \\
\hline Net Heat Rate (Btu/kWh) & 4,641 & 4,665 & 4,665 & 4,560 & 4,540 \\
\hline \multicolumn{6}{|c|}{ Emissions Characteristics - Engine out* } \\
\hline $\mathrm{NO}_{\mathrm{x}}(\mathrm{g} / \mathrm{bhp}-\mathrm{hr})$ & 2.0 & 1.5 & 1.0 & 0.5 & 0.1 \\
\hline CO (g/bhp-hr) & 2.0 & 2.0 & 1.5 & 1.5 & 1.0 \\
\hline VOC (g/bhp-hr) & 1.0 & 1.0 & 1.0 & 0.75 & 0.5 \\
\hline $\mathrm{CO}_{2}(\mathrm{lb} / \mathrm{MWh})$ & 1,283 & 1,267 & 1,228 & 1,192 & 1,140 \\
\hline
\end{tabular}

*Engine-out emissions could be reduced $90 \%$ through the use of SCR for NOx; an oxidation catalyst could reduce $\mathrm{CO}$ and VOC emissions by $98 \%$ or more; Exhaust-gas treatment would require an additional capital investment of $\$ 100 / \mathrm{kW}$ in the current year, decreasing to $\$ 50 / \mathrm{kW}$ in 2030 . 


\section{Table 11 (cont'd.) Current and Advanced Reciprocating Engine System Characteristics}

\begin{tabular}{|c|c|c|c|c|c|}
\hline \multicolumn{6}{|l|}{$\begin{array}{l}\text { Cost and Performance Projections, } \\
1,000 \mathrm{~kW} \text { Gas Engine CHP System - } \\
\text { Lean Burn }\end{array}$} \\
\hline Year & Current & 2005 & 2010 & 2020 & 2030 \\
\hline Total Installed Cost $(2003 \$ / \mathrm{kW})$ & 940 & 925 & 880 & 840 & 800 \\
\hline O\&M Costs $(2003 \$ / \mathrm{kWh})$ & 0.009 & 0.009 & 0.0085 & 0.0083 & 0.008 \\
\hline Electrical Heat Rate (Btu/kWh) & 10,035 & 9,611 & 9,099 & 8,638 & 8,222 \\
\hline Electric Efficiency (\%) & 34 & 36 & 38 & 40 & 42 \\
\hline Fuel Input (MMBtu/hr) & 10.1 & 9.61 & 9.10 & 8.64 & 8.22 \\
\hline \multicolumn{6}{|l|}{ CHP Characteristics } \\
\hline Total CHP Efficiency (\%) & 71 & 72 & 73 & 73 & 74 \\
\hline Heat Output (MMBtu/hr) & 3.7 & 3.5 & 3.2 & 2.9 & 2.7 \\
\hline Heat/Fuel Ratio & 0.37 & 0.36 & 0.35 & 0.34 & 0.33 \\
\hline Power/Heat Ratio & 0.92 & 0.97 & 1.07 & 1.18 & 1.26 \\
\hline Net Heat Rate (Btu/kWh) & 5,422 & 5,236 & 5,099 & 5,013 & 4,847 \\
\hline \multicolumn{6}{|l|}{ Emissions Characteristics - Engine out* } \\
\hline $\mathrm{NO}_{\mathrm{x}}(\mathrm{g} / \mathrm{bhp}-\mathrm{hr})$ & 1.0 & 0.7 & 0.5 & 0.25 & 0.1 \\
\hline $\mathrm{CO}$ (g/bhp-hr) & 2.0 & 2.0 & 1.5 & 1.5 & 1.0 \\
\hline VOC (g/bhp-hr) & 1.0 & 1.0 & 0.7 & 0.6 & 0.5 \\
\hline $\mathrm{CO}_{2}(\mathrm{lb} / \mathrm{MWh})$ & 1,175 & 1,124 & 1,065 & 1,010 & 962 \\
\hline
\end{tabular}

*Engine-out emissions could be reduced $90 \%$ through the use of SCR for NOx; an oxidation catalyst could reduce $\mathrm{CO}$ and VOC emissions by $98 \%$ or more; Exhaust-gas treatment would require an additional capital investment of $\$ 100 / \mathrm{kW}$ in the current year, decreasing to $\$ 50 / \mathrm{kW}$ in 2030 . 


\section{Table 11 (cont'd.) Current and Advanced Reciprocating Engine System Characteristics}

\begin{tabular}{|c|c|c|c|c|c|}
\hline \multicolumn{6}{|c|}{$\begin{array}{l}\text { Cost and Performance Projections, } \\
\text { 3,000 kW Gas Engine CHP System - } \\
\text { Lean Burn }\end{array}$} \\
\hline Year & Current & 2005 & 2010 & 2020 & 2030 \\
\hline Total Installed Cost $(2003 \$ / \mathrm{kW})$ & 935 & 920 & 870 & 830 & 790 \\
\hline O\&M Costs $(2003 \$ / \mathrm{kWh})$ & 0.0085 & 0.0085 & 0.0083 & 0.008 & 0.0075 \\
\hline Electrical Heat Rate (Btu/kWh) & 9,700 & 9,222 & 8,749 & 8,322 & 7,935 \\
\hline Electric Efficiency (\%) & 35 & 37 & 39 & 41 & 43 \\
\hline Fuel Input (MMBtu/hr) & 29.1 & 27.7 & 26.3 & 25.0 & 23.8 \\
\hline \multicolumn{6}{|l|}{ CHP Characteristics } \\
\hline Total CHP Efficiency (\%) & 69 & 71 & 72 & 73 & 74 \\
\hline Heat Output (MMBtu/hr) & 9.8 & 9.5 & 8.7 & 8.0 & 7.4 \\
\hline Heat/Fuel Ratio & 0.34 & 0.34 & 0.33 & 0.32 & 0.31 \\
\hline Power/Heat Ratio & 1.04 & 1.08 & 1.18 & 1.28 & 1.38 \\
\hline Net Heat Rate (Btu/kWh) & 5,599 & 5,263 & 5,124 & 4,989 & 4,852 \\
\hline \multicolumn{6}{|c|}{ Emissions Characteristics - Engine out* } \\
\hline $\mathrm{NO}_{\mathrm{x}}(\mathrm{g} / \mathrm{bhp}-\mathrm{hr})$ & 0.7 & 0.6 & 0.5 & 0.25 & 0.1 \\
\hline $\mathrm{CO}$ (g/bhp-hr) & 2.50 & 2.5 & 2.0 & 1.5 & 1.0 \\
\hline VOC (g/bhp-hr) & 1.3 & 1.3 & 1.0 & 0.7 & 0.5 \\
\hline $\mathrm{CO}_{2}(\mathrm{lb} / \mathrm{MWh})$ & 1,135 & 1,079 & 1,025 & 974 & 928 \\
\hline
\end{tabular}

*Engine-out emissions can be reduced $90 \%$ through the use of SCR for NOx; an oxidation catalyst can reduce CO and VOC emissions by $98 \%$ or greater; Exhaust-gas treatment would require an additional capital investment of $\$ 100 / \mathrm{kW}$ in the current year, declining to $\$ 50 / \mathrm{kW}$ in 2030 . 


\section{Table 11 (cont'd.) Current and Advanced Reciprocating Engine System Characteristics}

\begin{tabular}{|c|c|c|c|c|c|}
\hline \multicolumn{6}{|c|}{$\begin{array}{l}\text { Cost and Performance Projections, } \\
5,000 \mathrm{~kW} \text { Gas Engine CHP System - } \\
\text { Lean Burn }\end{array}$} \\
\hline Year & Current & 2005 & 2010 & 2020 & 2030 \\
\hline Total Installed Cost $(2003 \$ / \mathrm{kW})$ & 890 & 870 & 820 & 790 & 765 \\
\hline O\&M Costs $(2003 \$ / \mathrm{kWh})$ & 0.008 & 0.008 & 0.008 & 0.0078 & 0.0075 \\
\hline Electrical Heat Rate (Btu/kWh) & 9,213 & 8,749 & 8,322 & 7,935 & 7,582 \\
\hline Electric Efficiency (\%) & 37 & 39 & 41 & 43 & 45 \\
\hline Fuel Input (MMBtu/hr) & 46.1 & 43.7 & 41.6 & 39.7 & 37.9 \\
\hline \multicolumn{6}{|l|}{ CHP Characteristics } \\
\hline Total CHP Efficiency (\%) & 73 & 73 & 75 & 76 & 77 \\
\hline Heat Output (MMBtu/hr) & 16.7 & 15.0 & 14.0 & 13.0 & 12.0 \\
\hline Heat/Fuel Ratio & 0.36 & 0.34 & 0.34 & 0.33 & 0.32 \\
\hline Power/Heat Ratio & 1.02 & 1.14 & 1.22 & 1.31 & 1.42 \\
\hline Net Heat Rate (Btu/kWh) & 5,049 & 4,999 & 4,822 & 4,685 & 4,582 \\
\hline \multicolumn{6}{|c|}{ Emissions Characteristics - Engine out* } \\
\hline $\mathrm{NO}_{\mathrm{x}}(\mathrm{g} / \mathrm{bhp}-\mathrm{hr})$ & 0.5 & 0.5 & 0.40 & 0.25 & 0.1 \\
\hline CO (g/bhp-hr) & 2.40 & 2.4 & 2.0 & 1.5 & 1.0 \\
\hline VOC (g/bhp-hr) & 0.50 & 0.5 & 0.5 & 0.25 & 0.25 \\
\hline $\mathrm{CO}_{2}(\mathrm{lb} / \mathrm{MWh})$ & 1,078 & 1,025 & 974 & 928 & 887 \\
\hline
\end{tabular}

*Engine-out emissions could be reduced $90 \%$ through the use of SCR for NOx; an oxidation catalyst could reduce $\mathrm{CO}$ and VOC emissions by $98 \%$ or more; Exhaust-gas treatment would require an additional capital investment of $\$ 100 / \mathrm{kW}$ in the current year, decreasing to $\$ 50 / \mathrm{kW}$ in 2030 . 


\subsection{References}

Bining, Avtar; California Energy Commission, California Advanced Reciprocating Internal Combustion Engines Program, USDOE Reciprocating Engines Peer Review, Chicago, IL, April 23-24, 2002.

Bolis, Dave, Cummins; DOE ARES Program, USDOE Reciprocating Engines Peer Review, Chicago, IL, April 23-24, 2002.

Callahan, Timothy J.; Southwest Research Institute, Reciprocating Engine Technology - Can We Get There From Here?, USDOE Reciprocating Engines Peer Review, Chicago, IL, April 23-24, 2002.

Callahan, Timothy J.; Southwest Research Institute, Survey of Gas Engine Performance and Future Trends, 2003 Spring Technical Conference of the ASME Internal Combustion Engine Division, Salzburg, Austria, May 11-14, 2003.

Caterpillar, Inc., specifications sheet for G3636 LE natural gas engine, March 2003.

Coast Intelligen, Inc., specifications sheet for Model 150-IC genset, January 2003.

Cummins Engine Company, specifications sheet for QSV91G 1200 rpm natural gas engine, January 2002.

Cummins Engine Company, specifications sheet for GSK19G natural gas engine, January 2002.

Dress, Jim; Waukesha Engine, Advanced Natural Gas Reciprocating Engine Program, USDOE Reciprocating Engines Peer Review, Chicago, IL, April 23-24, 2002.

Energy Nexus Group, Performance and Cost Trajectories of Clean Distributed Generation Technologies, prepared for The Energy Foundation, May 29, 2002.

French, Timothy; Engine Manufacturers Association, National and State Environmental Issues: Implications for Reciprocating Engines, USDOE Reciprocating Engines Peer Review, Chicago, IL, April 23-24, 2002.

Haught, Debbie; U.S. Department of Energy, U.S. Department of Energy's Advanced Natural Gas Reciprocating Engine Program, USDOE Reciprocating Engines Peer Review, Chicago, IL, April 23-24, 2002.

Gerber, Gordon; Caterpillar, Advanced Reciprocating Engine Systems, USDOE Reciprocating Engines Peer Review, Chicago, IL, April 23-24, 2002.

"North American Diesel Progress," $24^{\text {th }}$ Annual Engine Yearbook, Volume 69, Number 6, June 2003. 
"North American Manufacturing Companies," North American Combustion Handbook, Second Edition, 1978.

Malm, Howard; REM Technologies, Air-Fuel Control and Emissions for Gas Engines, White Paper.

Onsite Energy Corporation, Small Reciprocating Engine Manufacturers and Generator Set Packagers, prepared for EPRI/GTI, GTI-00/0227, 2000.

Reciprocating Engines for Stationary Power Generation: Technology, Products, Players, and Business Issues, GRI, Chicago, IL and EPRIGEN, Palo Alto, CA: 1999. GRI-99/0271, EPRI TR113894.

Southwest Research Institute, Results of the Advanced Stationary, Reciprocating, Natural Gas Engine Workshop, San Antonio, TX, January 12-13, 1999.

Wartsila NSD North America, Inc., specification sheet for 18V34SG natural gas engine, January 2002.

Wilhelm, D., SFA Pacific, Inc., Reciprocating Engines for Stationary Power Generation, Prepared for GRI/EPRI, GRI99/0271/EPRI TR-113894, December 1999.

Reciprocating engine manufacturers/packagers:

Caterpillar, Inc., www.caterpillar.com

Cooper Energy Systems, www.cooperenergy.com

Coast Intelligen, Inc., www.coastintelligen.com

Cummins Engine Company, www.cummins.com

Fairbanks-Morse Engine Company, www.fairbanksmorse.com

Hess Microgen, Inc., www.hessmicrogen.com

Jenbacher Engines, www.jenbacher.com

Kohler Power Systems, www.kohlerpowersystems.com

Tecogen, Inc., www.tecogen.com

Waukesha Engine Inc., www.waukeshaengine.com

Wartsila NSD North America, Inc., www.wartsilausa.com 


\section{Small Gas Turbine Systems}

\subsection{Overview}

The gas turbine is one of the technology developments of the $20^{\text {th }}$ century that has made lasting changes in the way we use energy to make life more comfortable, convenient, and enjoyable. The gas turbine was pioneered as an engineering advancement in the early 1900s, then began to be used for stationary electric power generation in the late 1930s, revolutionized airplane propulsion in the 1940s, and is now the economically and environmentally preferred choice for new power generation plants in the United States.

Gas turbines are available in sizes ranging from 500 kilowatts $(\mathrm{kW})$ to 250 megawatts (MW). This section focuses on gas turbines in the size range of $1 \mathrm{MW}$ to $40 \mathrm{MW}$, suitable for use in distributed generation applications. The most efficient commercial technology for central station power generation is the gas turbine/steam turbine combined cycle plant, with efficiencies approaching 60\% (LHV). ${ }^{1}$ Simple-cycle gas turbines are available for on-site generation with efficiencies approaching 40\% (LHV). Gas turbines have long been used by utilities for peaking capacity. However, with changes in the power industry and advances in the technology, gas turbines now are being increasingly used for base-load power.

Gas turbines produce high-quality exhaust heat that can be used in combined heat and power (CHP) configurations to reach system efficiencies of $70 \%$ to $80 \%$. Turbine-based CHP systems use turbine exhaust directly for industrial processes such as drying or as input into a heat recovery steam generator that produces steam for process or space conditioning use. By the early 1980 s, the efficiency and reliability of small gas turbines (1 to $40 \mathrm{MW})$ had progressed sufficiently to be an attractive choice for industrial and large institutional users for CHP applications.

Gas turbines are one of the cleanest methods of generating electricity, with emissions of oxides of nitrogen $\left(\mathrm{NO}_{\mathrm{x}}\right)$ from some large turbines in the single-digit part-per-million (ppm) range, either with catalytic exhaust cleanup or lean premixed combustion. Because of their relatively high efficiency and reliance on natural gas as the primary fuel, gas turbines emit substantially less carbon dioxide $\left(\mathrm{CO}_{2}\right)$ per kilowatt-hour generated than any other technology in general commercial use.

\footnotetext{
1 The efficiencies quoted in this report are generally based on higher heating value (HHV), which includes the heat of condensation of the water vapor in the combustion products. In engineering and scientific literature, the lower heating value (LHV - which does not include the heat of condensation of the water vapor in the combustion products) is often used. The HHV is greater than the LHV by approximately $10 \%$ with natural gas as the fuel (i.e., $50 \%$ LHV efficiency is equivalent to $45 \%$ HHV efficiency). HHV efficiencies are about $8 \%$ greater for oil (liquid petroleum products) and 5\% for coal. The report specifically indicates the few instances where it uses lower heating values.
} 


\subsection{Applications}

Gas turbines are commonly used in the oil and gas industry to drive pumps and compressors, in process industries to drive compressors and other large mechanical equipment, and in many industrial and institutional facilities to generate electricity for use on-site. When used to generate power on-site, gas turbines are often used in combined heat and power mode where energy in the turbine exhaust is used to provide a portion of the thermal energy needs of the facility. With electric industry restructuring and technology improvements fostering a growing interest in distributed generation, gas turbines are expected to play an even greater role in providing power at or near the point of use. Potential distributed generation applications for gas turbines include peak shaving and on-peak systems, combined heat and power (CHP), and grid support.

\subsection{Power-Only}

\section{Standby Power}

Standby power systems are required by fire and safety codes for hospitals, elevator loads, and water pumping. Standby is an economic choice for customers with high outage costs such as telecommunications, retail, and certain process industries. Electric restructuring has resulted in a perception that outages have become more frequent and there are vulnerabilities to price spikes that could be avoided through standby power equipment. This application requires equipment with low capital cost, minimal installation costs, black-start capability (often with a 10 second start-up to load), and grid-isolated operation. Efficiency, emissions, and variable maintenance costs are not important in standby power applications. Low-cost diesel generators dominate this market. Gas turbines, in general, are too large and too expensive to be a viable option for most standby power applications.

\section{Peak Shaving}

In certain areas, customers generate on-site power to reduce their purchases of costly peak-load power. Power during peak periods is expensive on many existing rate schedules, and it is also expensive in competitive hourly power markets. Peak shaving benefits customers who have poor load factors or high demand charges. Typically, peak shaving does not involve heat recovery, but heat recovery may be warranted when the peak period is more than 2,000 hours/year. Generally, low equipment cost is the primary issue. Emissions may be an issue if operating hours are high. Where peak shaving can be combined with another value - such as standby power - the economics are considerably enhanced.

There are three possible peak-shaving strategies. First, customers can independently balance generated power against power purchased within the existing rate structure. Under this strategy, on-site generation would operate during the utility-defined peak periods. This creates an operating strategy that can vary, depending on the rate structure, from 900 hours/year to as much as 3,500 hours/year. Second, some utilities offer coordinated peak-shaving programs. The utility offers payments for very limited hours of use of the customer's equipment. These programs typically require as little as 50 hours/year to as many as 400 hours/year. Third, for 
customers who purchase power competitively, there is an opportunity to avoid purchasing electricity at the hourly competitive price or to select competitive interruptible power supply contracts from energy service providers. In the competitive market application, the hours of operation would probably be closer to the limited hours of the coordinated utility model than the independent peak shaving of a published rate structure.

In general, gas turbine operating performance is poor in applications with frequent starts and stops, and the capital costs of small gas turbines are higher than other alternatives, such as reciprocating engines, particularly in the $<5 \mathrm{MW}$ size range. Gas turbines will have a role in independent peak-shaving strategies for larger customers where operating hours approach intermediate duty, and high capital costs can be amortized over longer operating times.

\section{Grid Support}

Utilities are placing a growing number of 5 to $40 \mathrm{MW}$ gas turbines at substations to provide incremental capacity and grid support. Such installations can defer the need to expand transmission and distribution systems, can provide temporary peaking capacity within constrained areas, or can be used for system power factor correction and voltage support, thereby reducing costs for customers and the utility system. A number of turbine manufacturers and packagers offer mobile turbine-generator units in this size range. These units can be used in one location during a period of peak demand and then moved by truck to another location for the following season.

\subsection{Combined Heat and Power}

While the use of gas turbines is expected to grow in both grid support and customer peakshaving applications, the most prevalent on-site generation application for gas turbines has traditionally been CHP - and this trend is likely to continue. The economics of gas turbines in on-site generation applications often depend on effective use of the thermal energy contained in the exhaust gas, which generally represents $60 \%$ to $70 \%$ of the input fuel energy.

Efficiency and emissions are critical to this market application, and the high-temperature exhaust from gas turbines provides great flexibility in meeting thermal needs at the site. The most common use of this energy is for steam generation in unfired or supplementary-fired heat recovery steam generators (HRSGs). However, gas turbine exhaust gases can also be used as a source of direct process energy, for unfired or supplementary-fired process fluid heaters, or as preheated combustion air for power boilers. Because gas turbine exhaust is oxygen-rich and can support additional combustion, even greater flexibility can be achieved through supplementary firing of heat recovery steam generators (HRSGs). A duct burner can be fitted within the HRSG to raise the exhaust temperature and increase the amount and temperature of steam generated at incremental efficiencies of $90 \%$ LHV or greater.

An estimated 40,000 MW of gas turbine-based CHP capacity operated in the United States in 2000, located at more than 575 industrial and institutional facilities. Much of this capacity is concentrated in large combined-cycle CHP systems that maximize power production for sale to 
the grid by generating additional power from steam turbines before sending the steam to internal process needs or to heat the facility. However, a significant number of simple-cycle gas turbinebased CHP systems are in operation at a variety of applications, as shown in Figure 1. Simplecycle CHP applications are most prevalent in smaller installations, typically less than $40 \mathrm{MW}$ in size.

\section{Figure 1. Existing Simple-Cycle Gas Turbine CHP - 9,854 MW at 359 sites}

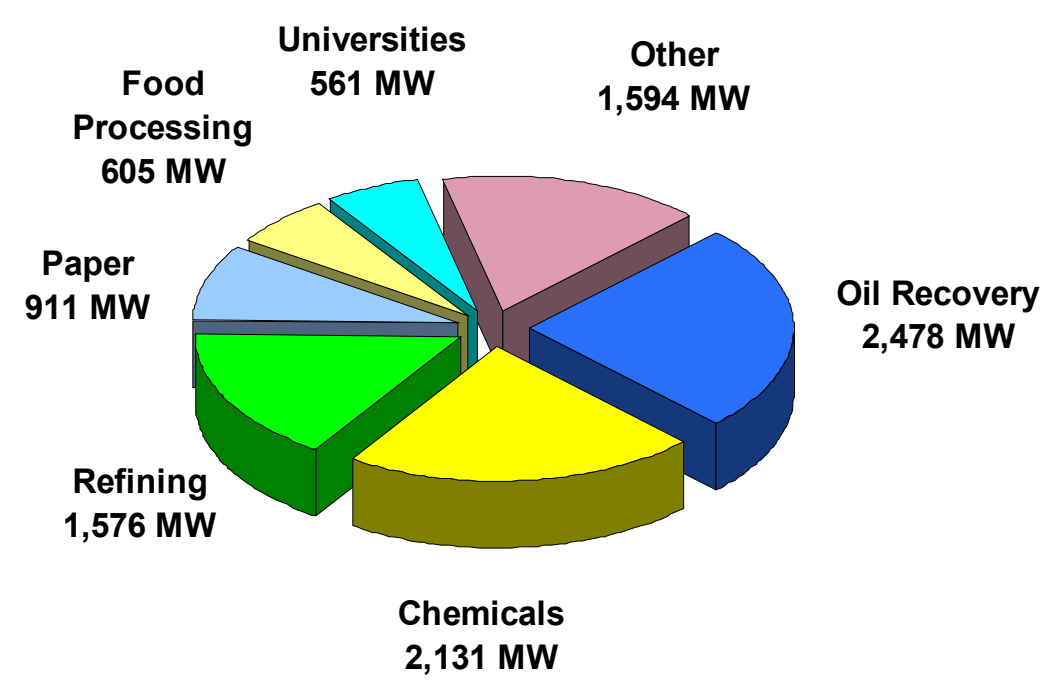

Source: Energy and Environmental Analysis, Inc., EEA CHP 2000 database

Gas turbines are ideally suited for CHP applications because their high-temperature exhaust can be used to generate process steam at conditions as high as 1,250 pounds per square inch gauge (psig) and $900^{\circ} \mathrm{F}$, or used directly in industrial processes for heating or drying. A typical industrial application for gas turbines is a chemicals plant with a $25 \mathrm{MW}$ simple-cycle gas turbine supplying base-load power to the plant and having an unfired HRSG on the exhaust. Approximately $29 \mathrm{MW}$ thermal $\left(\mathrm{MW}_{\text {th }}\right)$ of steam is produced at 150 to $1,000 \mathrm{psig}$ for process use within the plant. Overall efficiency for a CHP system of this type approaches $75 \%$.

A typical commercial/institutional application for gas turbines is a college or university campus with a $5 \mathrm{MW}$ simple-cycle gas turbine. Approximately $8 \mathrm{MW}_{\text {th }}$ of 150 to 400 psig steam is produced in an unfired HRSG and sent into a central steam loop for campus space-heating during winter months or to single-effect absorption chillers to provide cooling during the summer. Overall efficiency of this type of system may approach $70 \%$. 


\subsection{Technology Description}

\subsection{Basic Process and Components}

Gas turbine systems operate on the thermodynamic cycle known as the Brayton cycle. In a Brayton cycle, atmospheric air is compressed, heated, and then expanded. The shaft power produced by the expander (also called the turbine) that is not consumed by the compressor is used to generate electrical power. The power produced by an expansion turbine or consumed by a compressor is proportional to the absolute temperature of the gas passing through the device. Consequently, it is advantageous to operate the expansion turbine at the highest practical temperature consistent with economic materials and internal blade-cooling technology and to operate the compressor with inlet airflow temperature as low as possible. As technology advances permit higher turbine inlet temperature, the optimum pressure ratio also increases.

Higher temperatures and pressure ratios result in higher efficiency and higher specific power output (power out per unit of fuel energy in). Thus, the general trend in gas turbine advances has been toward a combination of higher temperatures and pressures. While such advances increase the manufacturing cost of the machine, the greater power output and higher efficiency provides net economic benefits. Industrial gas turbine manufacturers balance performance and cost to achieve the most economic machine.

\section{Modes of Operation}

Several variations of the Brayton cycle are in use today. Fuel consumption may be decreased by preheating the compressed air with heat from the turbine exhaust using a recuperator or regenerator; the compressor work may be reduced and net power increased by using intercooling or precooling the inlet air; and the exhaust may be used to raise steam in a boiler to generate additional power in a combined cycle. Primary components of a simple-cycle gas turbine are shown in Figure 2.

Figure 2. Components of a Simple-Cycle Gas Turbine

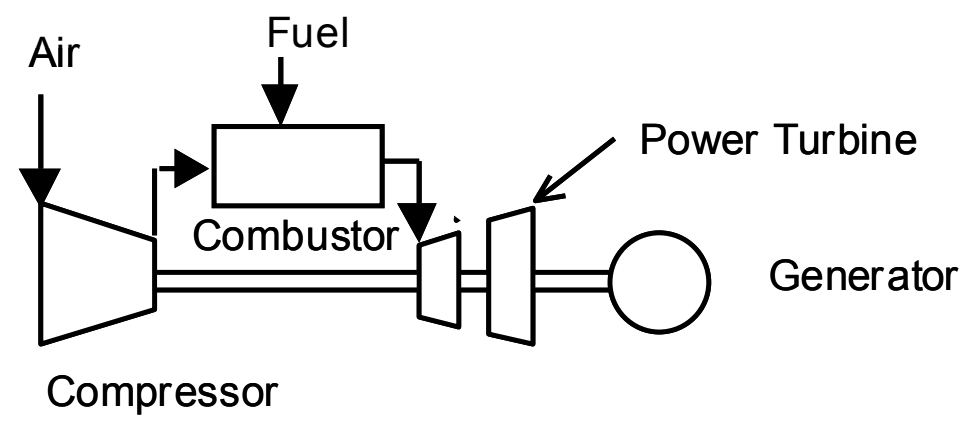

Gas-Fired Distributed Energy Resource Technology Characterizations Small Gas Turbine Systems - Page 3-5 
Gas turbine exhaust is quite hot, up to $800^{\circ} \mathrm{F}$ to $900^{\circ} \mathrm{F}$ for smaller industrial turbines and up to $1,100^{\circ} \mathrm{F}$ for some new, large central station utility machines and aeroderivative turbines. Such high exhaust temperatures permit the exhaust to be used directly in drying or in other directheating processes. With the addition of a HRSG, the exhaust heat can produce steam or hot water for process use or space conditioning. Finally, the steam generated by the HRSG may be used to generate additional electricity through a steam turbine in a combined-cycle configuration.

\subsection{Types of Gas Turbines}

Aeroderivative gas turbines for stationary power are adapted from their jet and turboshaft aircraft engine counterparts. While these turbines are lightweight and thermally efficient, they are usually more expensive than products designed and built exclusively for stationary applications. The largest aeroderivative turbines available are approximately $40 \mathrm{MW}$ in capacity. Many aeroderivative gas turbines for stationary use operate with compression ratios in the range of 30:1, requiring a high-pressure external fuel gas compressor. With advanced system developments, aeroderivatives are approaching 45\% simple-cycle efficiencies (LHV).

Industrial or frame gas turbines were developed exclusively for stationary power generation and are available in the 1 to $250 \mathrm{MW}$ capacity range. They are generally less expensive, more rugged, can operate longer between overhauls, and are better-suited for continuous base-load operation than aeroderivative turbines. However, they are less efficient and much heavier. Industrial gas turbines generally have more modest compression ratios (up to 16:1) and often do not require an external fuel gas compressor. Industrial gas turbines are approaching simple-cycle efficiencies of approximately $40 \%$ (LHV) and combined-cycle efficiencies of $60 \%$.

Gas turbines are being used successfully by industry for on-site power generation and as mechanical drives. Turbine sizes for these applications are typically $500 \mathrm{~kW}$ to $40 \mathrm{MW}$. Gas turbines drive compressors on long-distance natural gas pipelines. In the petroleum industry, they drive gas compressors to maintain well pressures and enable refineries and petrochemical plants to operate at high pressures. In the steel industry, they drive air compressors used for blast furnaces. In process industries such as chemicals, refining, paper and in large commercial and institutional applications, they are used in combined heat and power mode, generating electricity and steam for use on-site.

\subsection{Design Characteristics}

The features that characterize the use of gas turbines in CHP and other distributed generations applications include:

Thermal output: $\quad$ Gas turbines produce a high-quality (high-temperature) thermal output suitable for most combined heat and power applications. 
Fuel flexibility:

Reliability and life:

Size range:

Emissions:

Part-Load Operation:
High-pressure steam can, in turn, be generated or the exhaust can be used directly for process drying and heating.

Gas turbines operate on natural gas, synthetic gas, landfill gas, and fuel oils. Plants are often designed to operate on gaseous fuel with a stored liquid fuel for backup to obtain the less expensive interruptible rate for natural gas. Dual-fuel combustion capability is a purchase option on many gas turbines.

Modern gas turbines have proved to be reliable power generators, given proper maintenance. Time-to-overhaul is typically 25,000 to 50,000 hours.

Gas turbines are available in sizes from $500 \mathrm{~kW}$ to $250 \mathrm{MW}$, and can be selected to match the electric demands of most end-users (institutional, commercial, and industrial).

Many gas turbines burning gaseous fuels (mainly natural gas) feature lean premixed burners (also called dry low- $\mathrm{NO}_{\mathrm{x}}$ combustors) that emit less than $25 \mathrm{ppm}$ of $\mathrm{NO}_{\mathrm{x}}$, with laboratory performance down to $9 \mathrm{ppm}$, and simultaneous low $\mathrm{CO}$ emissions acceptable to regulators and safety personnel in the 50 to $100 \mathrm{ppm}$ range. ${ }^{2}$ Further reductions in $\mathrm{NO}_{\mathrm{x}}$ can be achieved by use of selective catalytic reduction (SCR) or catalytic combustion. Many gas turbines sited in locales with extremely stringent emission regulations use SCR after-treatment to achieve single-digit (below 9 ppm) $\mathrm{NO}_{\mathrm{x}}$ emissions.

Because gas turbine operators reduce power output by reducing combustion temperature, efficiency at part load can be substantially below that of full-power efficiency.

\subsection{Cost and Performance Characteristics}

This section describes the cost and performance of gas turbine systems for two primary applications. The first is for systems designed to produce power only. Systems configured for this purpose could be used in a variety of the applications described in Section 2, including peaking and grid support. The second configuration discussed in this section is combined heat

\footnotetext{
${ }^{2}$ Gas turbines have high oxygen content in their exhaust because they burn fuel with high excess air to limit combustion temperatures to levels that the turbine blades, combustion chamber, and transition section can handle without compromising system life. Consequently, emissions from gas turbines are evaluated at a reference condition of $15 \%$ oxygen. In comparison, boilers use 3\% oxygen as the reference condition for emissions, since they typically minimize excess air, to waste less heat in their exhaust. Due to the different amount of diluent gases in the combustion products, the mass of $\mathrm{NO}_{\mathrm{x}}$ per unit of fuel, measured as $9 \mathrm{ppm} @ 15 \%$ oxygen is equivalent to approximately 27 ppm@3\% oxygen.
} 
and power (CHP), where additional equipment is added to the basic turbine system to allow recovery and subsequent use of exhaust heat in industrial processes or commercial buildings. While CHP systems have many of the characteristics of power-only systems, they have additional complexity and require design tradeoffs that are described in this section.

The thermal efficiency of the Brayton cycle is a function of pressure ratio, ambient air temperature, turbine inlet air temperature, the efficiency of the compressor and turbine elements, turbine blade-cooling requirements, and any performance enhancements, such as recuperation, intercooling, inlet air cooling, reheat, or steam injection. All of these parameters, along with gas turbine internal mechanical design features, have been improved over time. Therefore, newer machines are usually more efficient than older ones of the same size and type. The performance of a gas turbine is also influenced by the purpose for which it is designed. Peaking units generally have lower efficiency and lower capital cost, while turbines intended for prime power or compressor applications with high annual capacity factors have design features that result in higher efficiency and higher capital costs.

\subsection{System Performance}

Table 1 provides an overview of gas turbine cost and performance characteristics of typical commercially available gas turbine systems in the 1 to $40 \mathrm{MW}$ size range. Gas turbine performance characteristics are shown in the top portion of the table and are applicable to both power-only and CHP applications. Total installed cost estimates are included for both applications. The heat rates shown were taken from manufacturers' specifications and industry publications. Available thermal energy (steam output) was calculated from published data on turbine exhaust temperatures and flows. CHP steam estimates are based on an unfired HRSG with an outlet exhaust temperature of $320^{\circ} \mathrm{F}$, producing dry, saturated steam at $150 \mathrm{psig}$. Higher steam pressures can be obtained, but at slightly lower overall efficiencies. Additional steam can be generated and total efficiency further increased with duct firing in the HRSG.

The data in Table 1 show that larger combustion turbines have higher electrical efficiencies. Higher electrical efficiencies mean that there is less thermal energy available to produce steam, leading to higher ratios of power to heat for large CHP systems. The ratio of power to heat affects project economics and may affect the decisions that customers make in terms of CHP acceptance, sizing, and the desirability of selling power. 
Table 1. Gas Turbine Systems - Typical Performance Parameters (2003)

\begin{tabular}{|c|c|c|c|c|c|}
\hline Cost and Performance Characteristics ${ }^{3}$ & System 1 & System 2 & System 3 & System 4 & System 5 \\
\hline Nominal Capacity (kW) & 1,000 & 5,000 & 10,000 & 25,000 & 40,000 \\
\hline \multicolumn{6}{|l|}{ Gas Turbine Characteristics } \\
\hline Electrical Efficiency (\%), LHV & 24.3 & 30.1 & 32.2 & 38.0 & 41.0 \\
\hline Electric Heat Rate (Btu/kWh), $\mathrm{HHV}^{4}$ & 15,580 & 12,590 & 11,765 & 9,945 & 9,220 \\
\hline Electrical Efficiency (\%), HHV & 21.9 & 27.1 & 29.0 & 34.3 & 37.0 \\
\hline Fuel Input (MMBtu/hr) & 15.6 & 62.9 & 117.7 & 248.7 & 368.8 \\
\hline Installed Cost - Power Only (2003 \$/kW) & 1,403 & 779 & 716 & 659 & 592 \\
\hline Installed Cost - CHP $(2003 \$ / \mathrm{kW})^{5}$ & 1,910 & 1,024 & 928 & 800 & 702 \\
\hline O\&M Costs (2003 \$/kWh) & 0.0096 & 0.0059 & 0.0055 & 0.0049 & 0.0042 \\
\hline Required Fuel Gas Pressure (psig) & 95 & 160 & 250 & 340 & 435 \\
\hline \multicolumn{6}{|l|}{ CHP Characteristics } \\
\hline Exhaust Flow $(1,000 \mathrm{lb} / \mathrm{hr})$ & 44 & 162 & 316 & 571 & 954 \\
\hline Turbine Exhaust Temperature $\left({ }^{\circ} \mathrm{F}\right)$ & 950 & 950 & 915 & 950 & 854 \\
\hline HRSG Exhaust Temperature $\left({ }^{\circ} \mathrm{F}\right)$ & 320 & 320 & 320 & 320 & 320 \\
\hline Steam Output (MMBtu/hr) & 6.7 & 25.0 & 46.5 & 89.9 & 127.3 \\
\hline Total CHP Efficiency $^{6}$ & 65 & 67 & 69 & 70 & 72 \\
\hline Heat/Fuel Ratio ${ }^{7}$ & 0.43 & 0.40 & 0.40 & 0.36 & 0.35 \\
\hline Power/Heat Ratio ${ }^{8}$ & 0.51 & 0.68 & 0.73 & 0.95 & 1.07 \\
\hline Net Heat Rate $(\mathrm{Btu} / \mathrm{kWh})^{9}$ & 7,205 & 6,343 & 5,953 & 5,453 & 5,242 \\
\hline
\end{tabular}

Source: Energy and Environmental Analysis, Inc., estimates for "typical" commercially available turbine systems.

\footnotetext{
${ }^{3}$ Data based on manufacturer specifications for: Solar Turbines Saturn $20-1 \mathrm{MW}$; Solar Turbines Taurus $60-5$ MW; Solar Turbines Mars 100 - 10 MW; GE LM2500 - 25 MW; GE LM6000 - 40 MW. Energy use and flows normalized to nominal system sizes $(\mathrm{kW})$.

${ }^{4}$ All turbine and engine manufacturers quote heat rates in terms of the lower heating value (LHV) of the fuel. On the other hand, the purchase price of fuels on an energy basis is typically measured on a higher heating value basis (HHV). In addition, electric utilities measure power plant heat rates in terms of HHV. For natural gas, the average heat content of natural gas is $1030 \mathrm{Btu} / \mathrm{kWh}$ on an HHV basis and $930 \mathrm{Btu} / \mathrm{kWh}$ on an LHV basis - or about a $10 \%$ difference.

${ }^{5}$ Installed costs are based on CHP system producing 150 psig saturated steam with an unfired heat recovery steam generator.

${ }^{6}$ Total CHP Efficiency $=($ net electric generated + net thermal energy recovered $) /$ total gas turbine fuel input.

${ }^{7}$ Heat $/$ Fuel Ratio $=$ Thermal output (total heat recovered MMBtu/hr) as a fraction of fuel input (MMBtu/hr).

${ }^{8}$ Power/Heat Ratio $=(\mathrm{CHP}$ electric power output $($ Btu equivalent $) /$ useful steam ouput $(\mathrm{Btu})$.

${ }^{9}$ Net Heat Rate $=($ Total fuel input to the CHP system - fuel normally used to generate the same amount of thermal output as the CHP system thermal output, assuming efficiency of $80 \%$ )/CHP electric output (kW).
} 


\section{Fuel Supply Pressure}

Gas turbines need a minimum fuel supply gas pressure of about 100 psig for the smallest turbines and substantially higher pressures for larger turbines and aeroderivative machines. The cost and power consumption of the fuel gas compressor can be a significant consideration depending on the supply pressure of the gas being delivered to the site. Table $\mathbf{2}$ shows the power required to compress natural gas from supply pressures typical of commercial and industrial service to the pressures required by typical industrial gas turbines. Typically, required supply pressures increase with gas turbine size, and this increase is reflected in the calculated fuel compression power requirements.

Table 2. Power Requirements for Natural Gas Compression ${ }^{10}$

\begin{tabular}{|l|c|c|c|c|c|}
\hline & System 1 & System 2 & System 3 & System 4 & System 5 \\
\hline Turbine Electric Capacity (kW) & 1,000 & 5,000 & 10,000 & 25,000 & 40,000 \\
\hline Turbine Pressure Ratio & 6.5 & 10.9 & 17.1 & 23.1 & 29.6 \\
\hline Required Compression Power (kW) & & & & & \\
\hline 50 psig gas supply pressure & $17 \mathrm{~kW}$ & $125 \mathrm{~kW}$ & $310 \mathrm{~kW}$ & $650 \mathrm{~kW}$ & $1310 \mathrm{~kW}$ \\
\hline 150 psig gas supply pressure & NA & $26 \mathrm{~kW}$ & $120 \mathrm{~kW}$ & $300 \mathrm{~kW}$ & $675 \mathrm{~kW}$ \\
\hline 250 psig gas supply pressure & NA & NA & $40 \mathrm{~kW}$ & $150 \mathrm{~kW}$ & $380 \mathrm{~kW}$ \\
\hline
\end{tabular}

${ }^{10}$ Fuel gas pressure requirements were calculated assuming that the compressor would deliver natural gas at an absolute pressure 35\% greater than the compressor discharge pressure in order to meet the requirements of the gas turbine flow control system and combustor mixing nozzles. Mass flow of fuel was based on the fuel requirements of reference gas turbines in the size range considered, assuming a 95\%-efficient electric motor driving the fuel compressor. Gas supply pressures of 50 psig, 150 psig, and 250 psig form the basis of the calculations 


\section{Part-Load Performance}

When less than full power is required from a gas turbine, the output is reduced by lowering the turbine inlet temperature. In addition to reducing power, this change in operating conditions also reduces efficiency. A typical part-load derate curve for efficiency is shown in Figure 3.

Figure 3. Part-Load Power Performance*

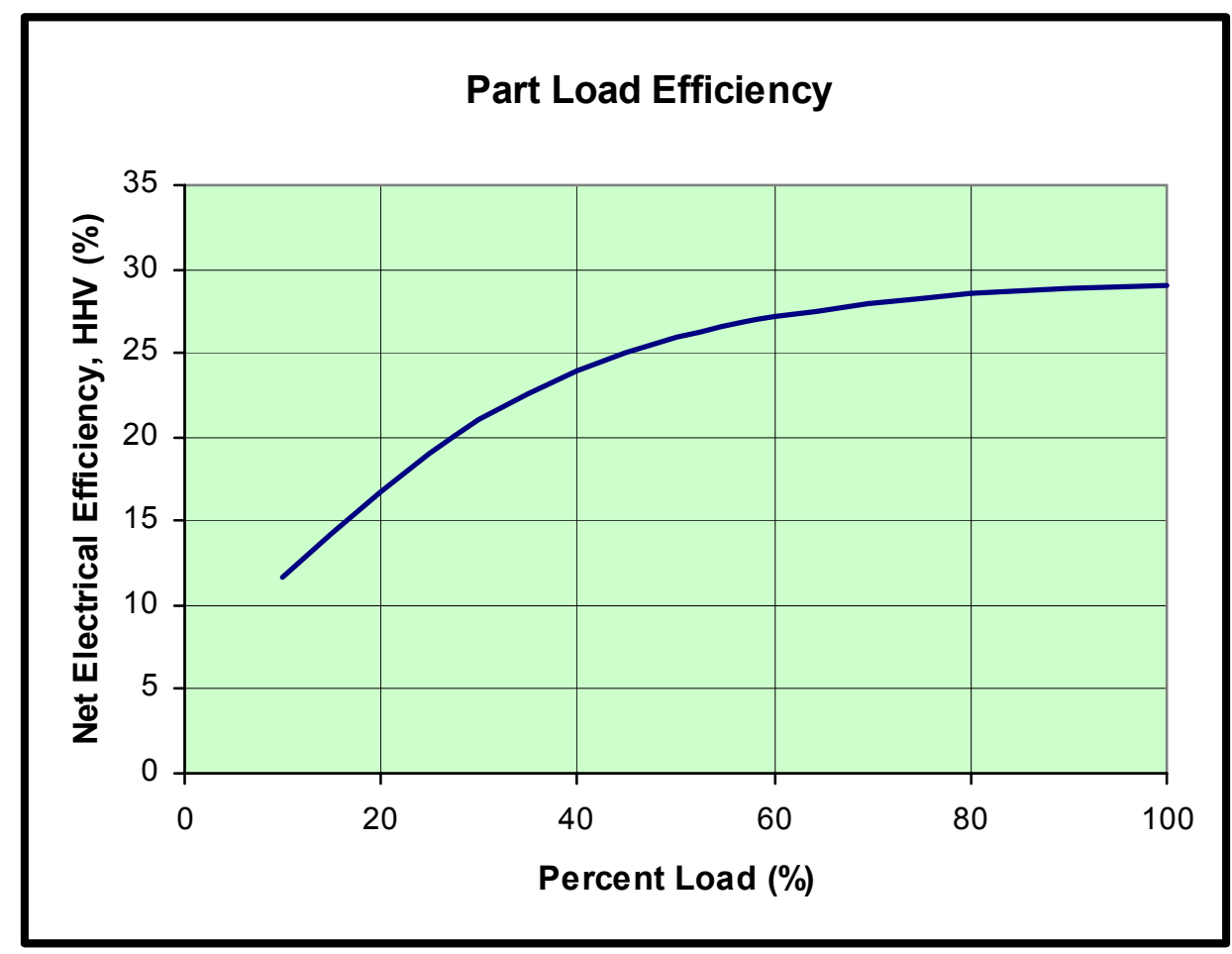

${ }^{*}$ Part-load performance estimate based on a $10 \mathrm{MW}$ Solar Mars turbine

\section{Effects of Ambient Conditions on Performance}

The ambient conditions under which a gas turbine operates noticeably affect both power output and efficiency. At higher inlet air temperatures, both the power and efficiency are lower. The power decreases due to the decreased air mass flow rate (the density of air declines as temperature increases), and the efficiency decreases because the compressor requires more power to compress warmer air. Conversely, the power and efficiency are higher for lower inlet air temperatures. Figure 4 shows the variation in power and efficiency for a gas turbine as functions of ambient temperature, compared to the reference International Organization for Standards (ISO) condition of sea level and $59^{\circ} \mathrm{F}$. At inlet air temperatures of near $100^{\circ} \mathrm{F}$, power output can be as low as $90 \%$ of ISO-rated power for typical gas turbines. At cooler temperatures of 40 to $50^{\circ} \mathrm{F}$, power output can be as high as $105 \%$ of ISO-rated power. 
Figure 4. Ambient Temperature Effects on Performance

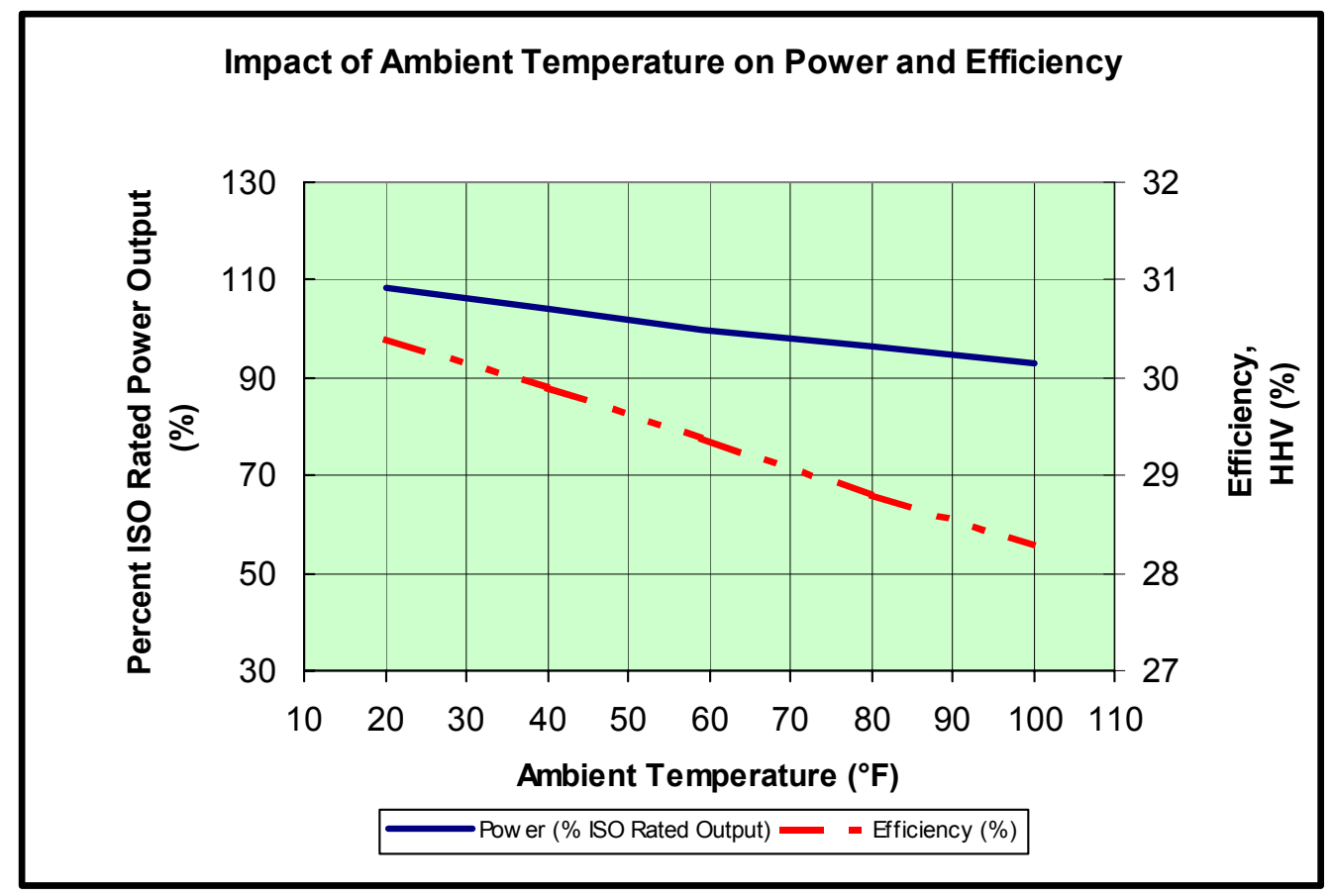

The density of air decreases with altitude; and, consequently, power output decreases. Figure 5 shows the derate in power due to altitude. Efficiency remains essentially constant with altitude.

Figure 5. Altitude Effects on Power Output

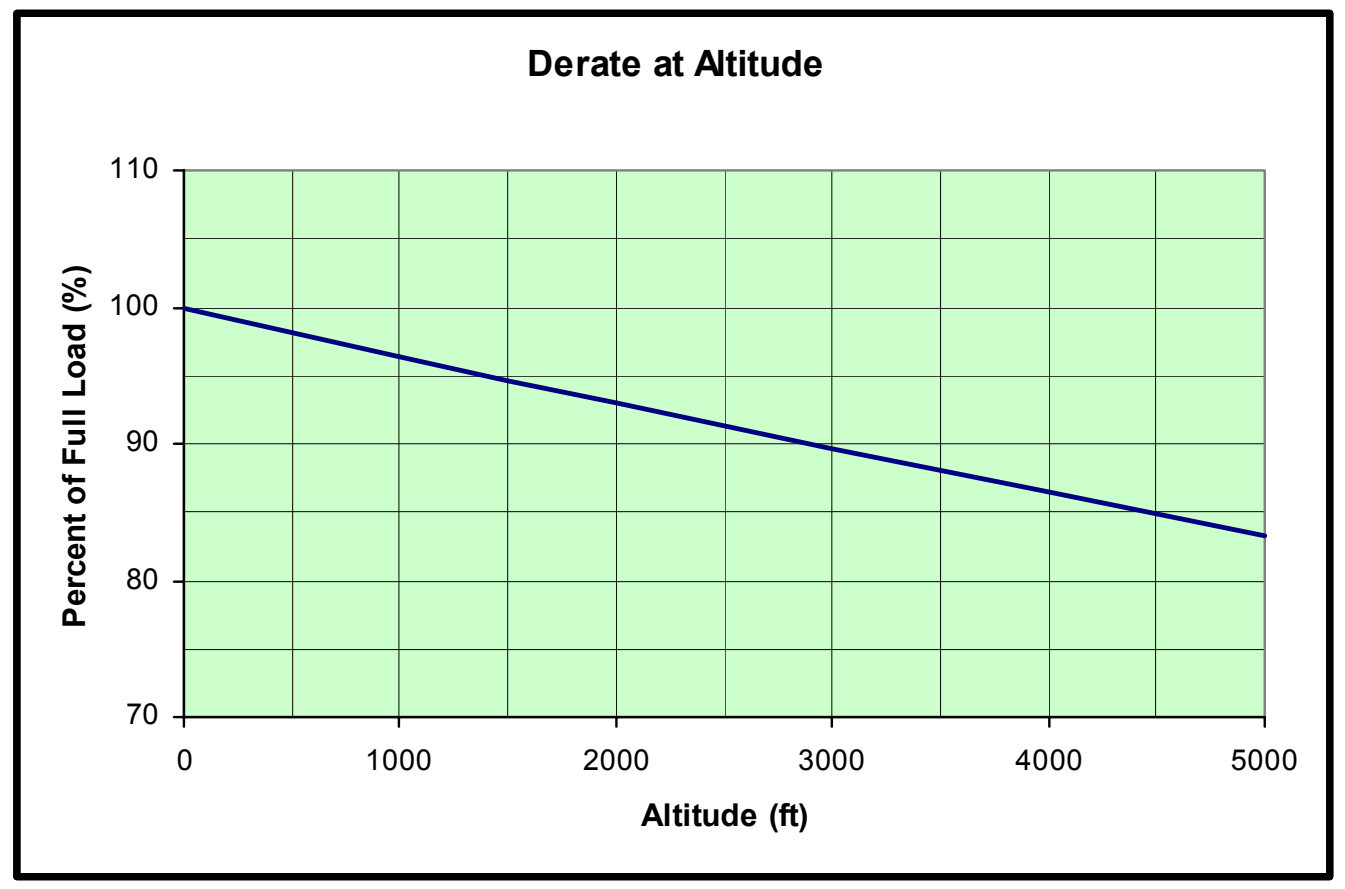

Gas-Fired Distributed Energy Resource Technology Characterizations Small Gas Turbine Systems - Page 3-12 


\subsection{Combined Heat and Power Performance}

The economics of gas turbines in process applications often depend on effective use of the thermal energy of the exhaust gas, which is generally $60 \%$ to $70 \%$ of the inlet fuel energy. The most common use of this energy is for steam generation in unfired or supplementary-fired HRSGs. However, the turbine exhaust gases also can be used as a source of direct process energy for unfired or fired process fluid heaters or as preheated combustion air for power boilers. Figure 6 shows a typical gas turbine/HRSG configuration. An unfired HRSG is the simplest steam CHP configuration and can generate steam at conditions ranging from $150 \mathrm{psig}$, saturated, to approximately $1,450 \mathrm{psig}, 950^{\circ} \mathrm{F}$.

\section{Figure 6. Heat Recovery from a Gas Turbine}

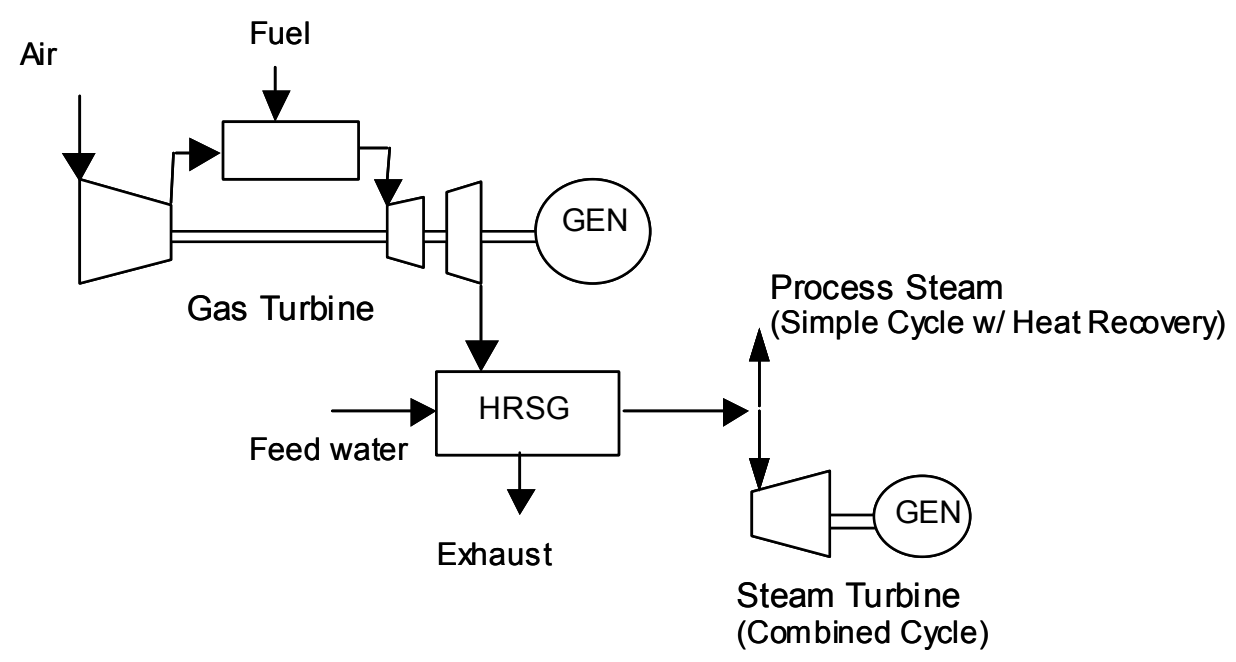

\section{CHP System Efficiency}

The overall efficiency of a CHP system depends on the amount of energy recovered from the turbine exhaust gas. The two most important factors influencing the amount of energy available for steam generation are gas turbine exhaust temperature and HRSG stack temperature.

Gas turbine exhaust temperature is set by the turbine firing temperature and turbine pressure ratio. Typically, aeroderivative gas turbines have higher firing temperatures than industrial gas turbines, but the higher pressure ratios in aeroderative gas turbines compensates for the higher firing temperature, so the discharge temperatures of the two turbine types are close, typically in the range of 850 to $950^{\circ} \mathrm{F}$. For the same HRSG stack temperature, higher turbine exhaust temperature (higher HRSG gas inlet temperature) results in more available thermal energy and increased HRSG output.

Similarly, lower HRSG stack temperatures reflect a greater amount of energy recovery and higher total system efficiency. HRSG stack temperature is a function of steam conditions and fuel type. Saturated steam temperatures increase with increasing steam pressure. Because of 
pinch-point considerations within the HRSG, higher steam pressures result in higher HRSG exhaust stack temperatures, less utilization of available thermal energy, and lower CHP system efficiency. In general, stack temperatures above $300^{\circ} \mathrm{F}$ are recommended for sulfur-bearing fuels to avoid condensation of corrosive acids in the equipment. Figure 7 illustrates the increase in overall system efficiency as the exhaust temperature is decreased through effective heat recovery. Generally, unfired HRSGs can be designed to economically recover approximately $95 \%$ of the available energy in the turbine exhaust (the energy released in going from turbine exhaust temperature to the HRSG exhaust temperature).

Figure 7. Effect of HRSG Stack Temperature on Total CHP Efficiency*

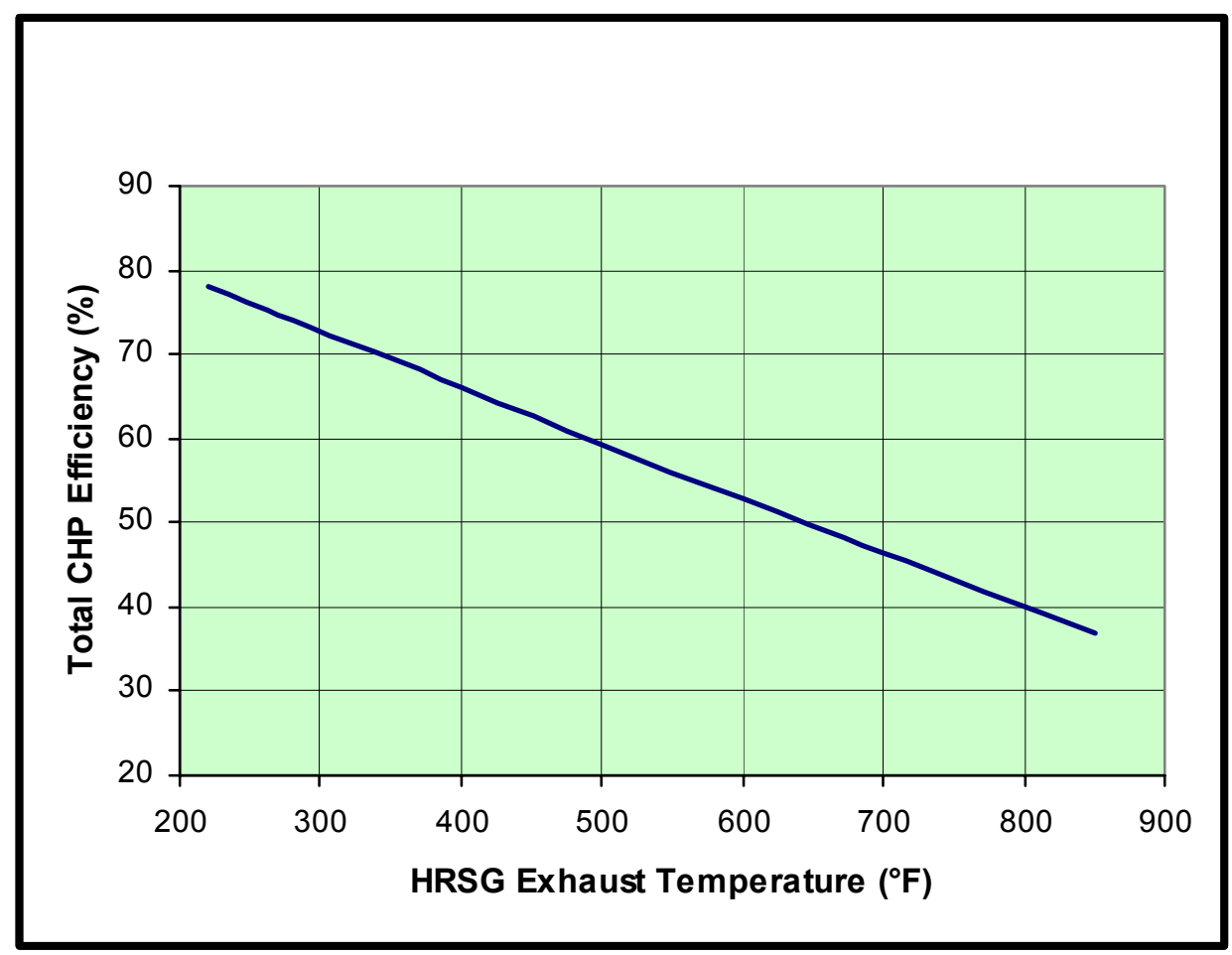

* Based on a GE LM6000 system with unfired HRSG

\section{Supplementary Firing}

Since gas turbines generally consume little of the available oxygen in the turbine airflow, the oxygen content of the turbine exhaust permits supplementary fuel firing upstream of the HRSG to increase steam production relative to an unfired unit. Supplementary firing can raise the temperature of the gas entering the HRSG to $2400^{\circ} \mathrm{F}$ and more than double the amount of steam produced by the unit. Since the turbine exhaust gas is essentially preheated combustion air, less fuel is consumed in supplementary firing than would be required for a standalone boiler providing the same incremental steam generation. The efficiency of incremental steam production from supplementary firing above that of an unfired HRSG approaches $100 \%$ based on the LHV of the fuel (about 90\% HHV efficiency when using natural gas). 
Supplementary firing also increases system flexibility. Unfired HRSGs are typically convective heat exchangers that respond solely to the exhaust conditions of the gas turbine and do not easily allow for steam flow control. Supplementary firing provides the ability to control steam production rates, within the capability of the burner system, independent of the gas turbine operating mode.

\subsection{Performance and Efficiency Enhancements}

\section{Recuperators}

Several technologies that increase the output power and/or the efficiency of gas turbines have been developed and put into limited commercial service. Fuel use can be reduced (and hence efficiency improved) by using a heat exchanger called a recuperator which uses the hot turbine exhaust to preheat the compressed air entering the turbine combustor. Depending on gas turbine operating parameters, a recuperator can add up to 10 percentage points in machine efficiency, raising efficiency from $30 \%$ to $40 \%$. However, since there is increased pressure drop on both the compressed air and turbine exhaust sides of the recuperator, power output is typically reduced by $10 \%$ to $15 \%$.

Recuperators are expensive. Their cost can normally be justified only when the gas turbine operates for many full-power hours per year. For example, pipeline compressor station gas turbines frequently operate with very high annual capacity factors, and some pipeline gas turbines have utilized recuperators since the 1960s. Recuperators also lower the temperature of the gas turbine exhaust, reducing the turbine's effectiveness in CHP applications. Because recuperators are subject to large temperature differences, they are subject to significant thermal stresses. Cyclic operation can result in joint fatigue, causing the recuperator to develop leaks and lose power and effectiveness. Design and manufacturing advances have mitigated some of the cost and durability issues, and commercial recuperators have been introduced on microturbines and on a $4.2 \mathrm{MW}$ industrial gas turbine (through a project supported by the U.S. Department of Energy). The M1A1 Abrams (military) tank is powered by a recuperated gas turbine.

\section{Intercoolers}

Intercoolers are used to increase gas turbine power by dividing the compressor into two sections and cooling the compressed air leaving the first compressor section before it enters the second section. Intercoolers have been used for decades on industrial air compressors and are used on some reciprocating engine turbochargers. Intercoolers increase net power appreciably; but because the temperature of the gas delivered by the entire compressor is now cooler, more heat has to be supplied by the combustor. Gas turbine efficiency does not change significantly with the use of intercooling. 


\section{Inlet Air Cooling}

As shown in Figure 4, the lower power and efficiency of gas turbines at high ambient temperatures means that gas turbine performance is at its lowest at the times power is often in greatest demand and most valued. The figure also shows that cooling the air entering the turbine by $40^{\circ} \mathrm{F}$ to $50^{\circ} \mathrm{F}$ on a hot day can increase power output by $15 \%$ to $20 \%$. The decreased power and efficiency caused by high ambient air temperatures can be mitigated by any of several approaches to inlet air cooling, including refrigeration, evaporative cooling, and thermal energy storage using off-peak cooling.

With refrigeration cooling, either a compression-driven or thermally activated (absorption chiller) refrigeration cycle cools the inlet air through a heat exchanger. The heat exchanger in the inlet air stream causes an additional pressure drop in the air entering the compressor, thereby slightly lowering cycle power and efficiency. However, with the inlet air now substantially cooler than the ambient air, there is a significant net gain in power and efficiency. Compression refrigeration requires a substantial parasitic power loss if the compressors are driven by electric motors. Thermally activated absorption cooling can utilize waste heat from the gas turbine, reducing the direct parasitic loss. However, the complexity and cost of this approach pose potential drawbacks in many applications.

Evaporative cooling, which is widely used due to its low capital cost, sprays water directly into the inlet air stream. Evaporation of the water cools the air. Since cooling is limited to the wet bulb air temperature, evaporative cooling is most effective when the ambient air is dry. Evaporative cooling can consume large quantities of water, which may not be feasible in arid regions. It is offered on a few large gas turbines and is expected to be used more frequently on smaller machines in the future.

The use of thermal energy storage - typically ice, chilled water, or low-temperature fluids - to cool inlet air can eliminate most parasitic losses from the augmented power capacity. If on-peak power hours are narrowly defined, i.e., just a few hours per day, thermal energy storage may be a viable option. In that case, the shorter time of energy storage discharge and longer time for daily charging allow for a smaller, less expensive thermal energy storage system.

\subsection{Capital Cost}

This section provides estimates for the total installed cost of natural gas-fired turbine systems. Two configurations are presented: power-only and CHP. Capital costs (equipment and installation) are estimated for the five typical gas turbine systems ranging from $1 \mathrm{MW}$ to $40 \mathrm{MW}$ for each configuration. These are "typical" budgetary price levels to the end user. Installed costs can vary significantly depending on the scope of the plant equipment, geographical area, competitive market conditions, special site requirements, emissions control requirements, prevailing labor rates, and whether the installation is a new or retrofit application.

An industrial-size gas turbine generator is a complex system with many interrelated subsystems. The basic package consists of the gas turbine system, gearbox, electric generator, inlet and 
exhaust ducting, inlet air filtration, lubrication and cooling systems, standard starting system, and exhaust silencing. Most turbine packages sold for power generation in the United States are equipped with dry low emission (DLE) combustors. Figure 8 compares the basic package price per kilowatt as a function of total electric capacity for 90 turbine generator sets smaller than 50 MW. ${ }^{11}$ Smaller units may include an outdoor enclosure with control panel, batteries, and fire protection. The basic package prices average $\$ 300-400 / \mathrm{kW}$ for systems above $5 \mathrm{MW}$. The 1MW class systems are about twice as costly. The chart shows the best-fit power function trendline for these data. The trend line in Figure 8 shows the basic relationship between cost and size; but it does not closely track the prices of units smaller than $3 \mathrm{MW}$ or the concentration of low prices for 5-7 MW units - a very popular size for industrial applications.

\section{Figure 8. Turbine Generator Package Costs by Size}

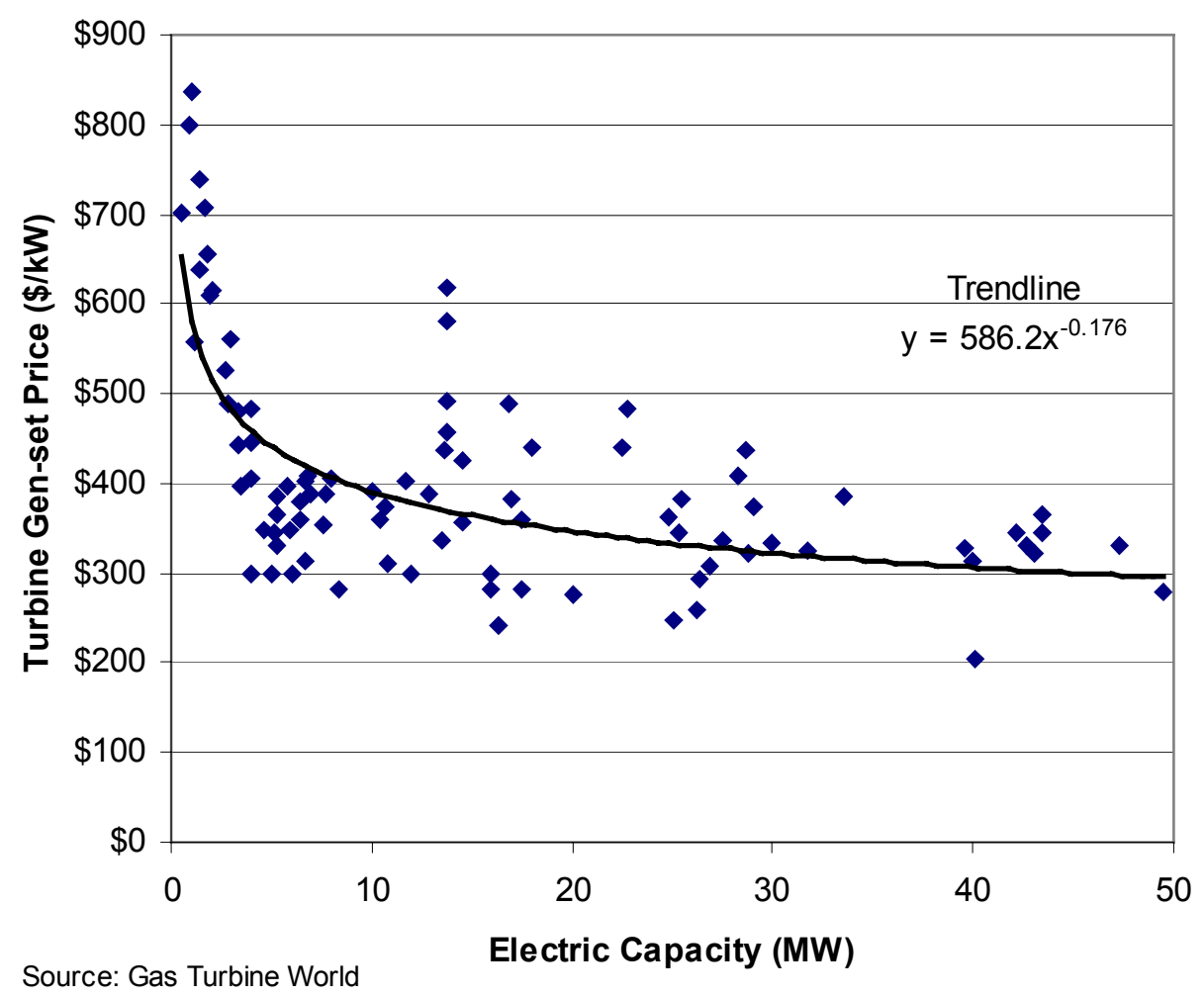

The basic package price in Figure 8 does not include extra components, such as fuel gas compressors, heat-recovery equipment, water treatment system, emissions controls (such as selective catalytic reduction), or continuous emission monitoring systems. Not all of these components are required at every site. The basic turbine package - plus the added systems needed for the particular application - comprise the total plant equipment. The total plant cost consists of the cost of all equipment plus freight, installation labor and materials, engineering, project management, site work, licensing and insurance, commissioning and start-up, permits, and licensing.

\footnotetext{
${ }^{11}$ Gas Turbine World: 2000-2001 Handbook, Pequot Publishing, Inc., 2000. 
There are definite economies of scale for larger turbine power systems. Turbine package costs (per MW) decline only slightly in the range of 5 to $40 \mathrm{MW}$, but ancillary equipment such as the HRSG, gas compression, water treatment, and electrical equipment cost much less per unit of electrical output for larger systems. This effect can be expressed in terms of the exponent or factor that relates the ratio of two plant sizes to their costs. Between $5 \mathrm{MW}$ and $40 \mathrm{MW}$, the factor for the basic package is 0.95 , whereas the factor for the total plant costs is 0.82 . The estimating formula is as follows:

$$
\operatorname{Cost}_{\mathrm{a}} \times\left(\operatorname{Size}_{\mathrm{b}} / \mathrm{Size}_{\mathrm{a}}\right)^{0.82}=\mathrm{Cost}_{\mathrm{b}}
$$

This relationship can be used to estimate the installed costs of systems of a different size than the specific examples estimated for this study.

Table 3. Estimated Capital Cost for Typical Gas Turbine Systems in Grid-Interconnected CHP Applications (2003) ${ }^{12}$

\begin{tabular}{|c|c|c|c|c|c|}
\hline Cost Component & System 1 & System 2 & System 3 & System 4 & System 5 \\
\hline Nominal Capacity (MW) & 1 & 5 & 10 & 25 & 40 \\
\hline \multicolumn{6}{|l|}{$\operatorname{Cost}(\$ / k W)$} \\
\hline Equipment & & & & & \\
\hline Combustion Turbines & 660 & 380 & 370 & 365 & 340 \\
\hline HRSG & 245 & 100 & 75 & 45 & 35 \\
\hline Water Treatment System & 25 & 20 & 14 & 9 & 5 \\
\hline Electrical Equipment & 125 & 65 & 50 & 42 & 32 \\
\hline Other Equipment ${ }^{13}$ & 120 & 65 & 65 & 50 & 50 \\
\hline Total Equipment & 1,175 & 630 & 574 & 511 & 462 \\
\hline Materials & 135 & 72 & 66 & 51 & 46 \\
\hline Labor & 341 & 183 & 166 & 133 & 102 \\
\hline Total Process Capital & 1,651 & 885 & 806 & 695 & 610 \\
\hline $\begin{array}{l}\text { Project/Construction } \\
\text { and Management }\end{array}$ & 118 & 63 & 57 & 51 & 46 \\
\hline Engineering and Fees & 82 & 44 & 36 & 28 & 23 \\
\hline Project Contingency & 59 & 32 & 29 & 26 & 23 \\
\hline Total Plant Cost (2003 \$/kW) & $\$ 1,910$ & $\$ 1,024$ & $\$ 928$ & $\$ 800$ & $\$ 702$ \\
\hline
\end{tabular}

\footnotetext{
${ }^{12}$ Combustion turbine costs are based on published specifications and package prices. The total installed cost estimates are based in part on the use of an EPRI proprietary cost and performance model - SOAPP-CT.25 - (for state-of-the-art power plant, combustion turbine). Actual costs can vary widely and are affected by site conditions and requirements, regional price variations, market competition and environmental and other local permitting requirements.

${ }^{13}$ Other Equipment includes the cost of a fuel gas compressor and additional miscellaneous equipment
} 
Table 3 provides cost estimates for the five typical gas turbine systems in CHP applications. The cost estimates are based on DLE emissions control, HRSG, fuel gas compression, treatment for the boiler feed water, basic utility interconnection for parallel power generation, and minimal site preparation. The estimates do not include costs of selective catalytic reduction system, supplementary firing or duct burners, or building construction. Labor/materials represent the labor cost for the civil, mechanical, and electrical work - and materials such as ductwork, piping, and wiring - and is estimated to range from $40 \%$ of the total equipment cost for smaller gas turbine systems to more than $30 \%$ for the largest. Project and construction management includes general contractor markup, bonding, and performance guarantees and is estimated at $10 \%$ of the total equipment cost for all sizes. Engineering and permitting fees are estimated to range from $5 \%$ to $7 \%$ of the total equipment cost depending on system size. Contingency is assumed to be $5 \%$ of the total equipment cost in all cases.

Table 4 shows the cost estimates on the same basis for power-only applications. In this case, the estimates do not include a cost for HRSG units or boiler feed-water conditioning. Power-only installation costs are estimated to be lower than CHP installation costs due to reduced project complexity and the lower performance risks associated with reduced system and process integration.

Table 4. Estimated Capital Cost for Typical Gas Turbine Systems in Grid-Interconnected Power-Only Applications (2003)

\begin{tabular}{|c|c|c|c|c|c|}
\hline Cost Component & System 1 & System 2 & System 3 & System 4 & System 5 \\
\hline Nominal Capacity (MW) & 1 & 5 & 10 & 25 & 40 \\
\hline $\operatorname{Cost}(\$ / k W)$ & & & & & \\
\hline Equipment & & & & & \\
\hline Combustion Turbines & 660 & 380 & 370 & 365 & 340 \\
\hline Electrical Equipment & 125 & 65 & 50 & 42 & 32 \\
\hline Other Equipment $^{14}$ & 120 & 65 & 65 & 50 & 50 \\
\hline Total Equipment & 905 & 510 & 485 & 457 & 422 \\
\hline Materials & 91 & 51 & 43 & 37 & 30 \\
\hline Labor & 226 & 115 & 95 & 80 & 63 \\
\hline Total Process Capital & 1,222 & 676 & 623 & 574 & 515 \\
\hline $\begin{array}{l}\text { Project/Construction } \\
\text { and Management }\end{array}$ & 91 & 51 & 48 & 46 & 42 \\
\hline Engineering & 45 & 26 & 21 & 16 & 14 \\
\hline Project Contingency & 45 & 26 & 24 & 23 & 21 \\
\hline Total Plant Cost (2003 \$/kW) & $\$ 1,403$ & $\$ 779$ & $\$ 716$ & $\$ 659$ & $\$ 592$ \\
\hline
\end{tabular}

${ }^{14}$ Other Equipment includes the cost of a fuel gas compressor and additional miscellaneous equipment Gas-Fired Distributed Energy Resource Technology Characterizations Small Gas Turbine Systems - Page 3-19 
Labor/materials, representing the labor cost for the civil, mechanical, and electrical work - and materials such as ductwork, piping, and wiring - is estimated to range from $35 \%$ of the total equipment cost for smaller systems to $22 \%$ for the largest installations. Project and construction management is estimated to be $10 \%$ of the total equipment cost for all systems. Engineering and permitting fees are estimated to range from $5 \%$ to $3 \%$ of the total equipment cost depending on turbine size. Contingency is assumed to be $5 \%$ of the total equipment cost in all cases.

\subsection{Maintenance}

Non-fuel operation and maintenance (O\&M) costs, presented in Table 5, are based on gas turbine manufacturer estimates for service contracts, which include routine inspections and scheduled overhauls of the turbine generator set. Routine maintenance practices include online running maintenance and preventive maintenance procedures. These procedures include predictive techniques, such as plotting trends in performance, fuel consumption, heat rate, and vibration. The O\&M costs presented in Table 5 include operating labor and total maintenance costs for routine inspections and procedures and major overhauls.

Table 5. Typical Gas Turbine (Non-fuel) O\&M Costs (2003)

\begin{tabular}{|l|c|c|c|c|c|}
\hline O\&M Costs $^{15}$ & $\begin{array}{c}\text { System } \\
\mathbf{1}\end{array}$ & $\begin{array}{c}\text { System } \\
\mathbf{2}\end{array}$ & $\begin{array}{c}\text { System } \\
\mathbf{3}\end{array}$ & $\begin{array}{c}\text { System } \\
\mathbf{4}\end{array}$ & $\begin{array}{c}\text { System } \\
\mathbf{5}\end{array}$ \\
\hline & & & & & \\
Nominal Capacity, MW & 1 & 5 & 10 & 25 & 40 \\
Variable (service contract), \$/kWh & 0.0045 & 0.0045 & 0.0045 & 0.0040 & 0.0035 \\
Variable (consumables), \$/kWh & 0.0001 & 0.0001 & 0.0001 & 0.0001 & 0.0001 \\
Fixed, \$/kW-yr & 40 & 10 & 7.5 & 6 & 5 \\
Fixed, \$/kWh @ 8000 hrs/yr & 0.0050 & 0.0013 & 0.0009 & 0.0008 & 0.0006 \\
& & & & & \\
\hline Total O\&M Costs, (2003 \$/kWh) & 0.0096 & 0.0059 & 0.0055 & 0.0049 & 0.0042 \\
\hline
\end{tabular}

Daily maintenance by site personnel includes visual inspection of filters and general site conditions. Routine inspections are required every 4,000 hours to ensure that the turbine is free of excessive vibration due to worn bearings, rotors or damaged blade tips. Inspections generally include on-site hot-gas-path boroscope inspections and nondestructive component testing using dye penetrant and magnetic particle techniques to ensure the integrity of components. The combustion path is inspected for fuel nozzle cleanliness and wear, along with the integrity of other hot gas-path components.

Gas turbines need to be overhauled every 25,000 to 50,000 hours, depending on service, and the overhaul is typically a complete inspection and rebuild of components to restore the gas turbine to original or current (upgraded) performance standards. A typical overhaul consists of

\footnotetext{
${ }^{15} \mathrm{O \& M}$ costs presented in Table 5 are based on 8,000 annual operating hours. Fixed costs are based on an interpolation of manufacturers' estimates. The variable component of the O\&M cost represents the inspections and overhaul procedures that are normally conducted by the prime mover original equipment manufacturer through a service agreement that is usually based on operating hours.
}

Gas-Fired Distributed Energy Resource Technology Characterizations Small Gas Turbine Systems - Page 3-20 
dimensional inspections, upgrading and testing of the turbine and compressor, rotor removal, inspection of thrust and journal bearings, blade inspection and clearances, and setting packing seals.

Gas turbine maintenance costs can vary significantly, depending on the quality and diligence of the preventative maintenance program and operating conditions. Although gas turbines can be cycled, maintenance costs for a gas turbine that is cycled every hour can be three times as high as for a turbine that is operated for intervals of 1,000 hours or more. Operating a turbine above its rated capacity for significant periods of time will dramatically increase the number of hot path inspections and overhauls needed. Gas turbines that operate for extended times on liquid fuels will need shorter than average overhaul intervals.

\subsection{Fuels}

All gas turbines intended for service as stationary power generators in the United States are available with combustors equipped to burn natural gas. A typical range of heating values of gaseous fuels acceptable for gas turbines is 900 to 1,100 Btu per standard cubic foot (SCF), which covers the range of pipeline quality natural gas. Clean liquid fuels are also suitable for use in gas turbines.

Special combustors developed by some gas turbine manufacturers can handle cleaned gasified solid and liquid fuels. Burners have been developed for medium-Btu fuel (400 to $500 \mathrm{Btu} / \mathrm{SCF}$ ), which is produced in oxygen-blown gasifiers, and for low-Btu fuel (90 to $125 \mathrm{Btu} / \mathrm{SCF}$ ), which is produced in air-blown gasifiers. These special combustors were developed principally for large gas turbines and are not found on small gas turbines. Fuel contaminants, such as ash, alkalis (sodium and potassium), and sulfur result in alkali sulfate deposits, which impede flow, degrade performance, and cause corrosion in the turbine hot section. Fuels are permitted to have only low levels of specified contaminants in them (typically less than $10 \mathrm{ppm}$ total alkalis and single-digit ppm of sulfur).

Liquid fuels require their own pumps, flow control, nozzles and mixing systems. Many gas turbines are available with either gas- or liquid-firing capability. In general, these gas turbines can be converted from one fuel to another quickly. Several gas turbines are equipped for dualfuel firing and can switch fuels with minimal or no interruption.

Lean-burn/dry low $\mathrm{NO}_{\mathrm{x}}$ combustors can generate $\mathrm{NO}_{\mathrm{x}}$ emissions levels as low as $9 \mathrm{ppm}$ (at $15 \%$ $\mathrm{O}_{2}$ ), while those with liquid fuel combustors have $\mathrm{NO}_{\mathrm{x}}$ emissions as low as approximately 25 ppm (at $\left.15 \% \mathrm{O}_{2}\right)$. There is no substantial difference in general performance with either fuel. However, the different heats of combustion result in slightly higher mass flows through the expansion turbine when liquid fuels are used, and thus a very small increase in power and efficiency performance is obtained. Also, the fuel pump power requirements for liquid fuels are less than those of fuel gas booster compressors, thereby further increasing net performance with liquid fuels. 
Gas turbine combustors operate at pressure levels of 75 to 350 psi. While pipeline pressure of natural gas is higher in interstate transmission lines, the pressure is typically reduced at the city gate metering station before it flows into the local distribution piping system. Quite often, a fuel gas booster compressor is required to ensure that fuel pressure is adequate for the gas turbine flow control and combustion systems. The cost of the fuel gas booster compressors adds to the installation capital cost. Often, redundant booster compressors are used, because gas turbines cannot operate stably without adequate fuel pressure. Liquid-fueled gas turbines use pumps to deliver the fuel to the combustors.

\subsection{Availability and Life}

Many operational conditions affect a gas turbine's propensity to fail. Frequent starts and stops cause damage from thermal cycling, which accelerates mechanical failure. Use of liquid fuels, especially heavy fuels and fuels with impurities, radiates heat to the combustor walls significantly more intensely than occurs with clean gaseous fuels, thereby overheating the combustor and transition section walls. On the other hand, gas turbines in steady operation on clean fuels can operate for a year without needing to shut down.

Estimated availability of gas turbines in continuous operation on clean gaseous fuels like natural gas is in excess of $98 \%$. Use of distillate fuels and other liquid fuels, especially those with contaminants (alkalis, sulfur, and ash), require more frequent shutdowns for preventive maintenance, and this reduces availability.

The economic life of gas turbine systems is estimated to be 20 years; this includes several major overhauls during that time. Costs of these overhauls are included in the non-fuel maintenance estimates presented earlier in the report

\subsection{Emission Characteristics}

Gas turbines are among the cleanest fossil-fueled power-generation equipment commercially available. Gas turbine emission-control technologies are continuing to evolve, with older technologies being gradually phased out as new technologies are developed and commercialized. The primary pollutants from gas turbines are oxides of nitrogen $\left(\mathrm{NO}_{\mathrm{x}}\right)$, carbon monoxide $(\mathrm{CO})$, and volatile organic compounds (VOCs). Other pollutants such as oxides of sulfur $\left(\mathrm{SO}_{\mathrm{x}}\right)$ and particulate matter depend primarily on the fuel used. Emissions of sulfur compounds, primarily $\mathrm{SO}_{2}$, reflect the sulfur content of the fuel. Gas turbines operating on natural gas or distillate oil that has been desulfurized in the refinery emit insignificant levels of $\mathrm{SO}_{\mathrm{x}}$. In general, $\mathrm{SO}_{\mathrm{x}}$ emissions are significant only if heavy oils are fired in the turbine, and $\mathrm{SO}_{\mathrm{x}}$ control is a fuelpurchasing issue rather than a turbine technology issue. Particulate matter is a marginally significant pollutant for gas turbines using liquid fuels. Ash and metallic additives in the fuel may contribute to particulate matter in the exhaust.

It is important to note that the gas turbine operating load has a significant effect on the emissions levels of the primary pollutants $\left(\mathrm{NO}_{\mathrm{x}}, \mathrm{CO}\right.$, and VOCs). Gas turbines are typically operated at 
high loads; and, therefore, are designed to achieve maximum efficiency and optimum combustion at these high loads. Controlling all pollutants simultaneously at all load conditions is difficult. At higher loads, higher $\mathrm{NO}_{\mathrm{x}}$ emissions are expected, due to peak flame temperatures. At lower loads, lower thermal efficiency and less complete combustion occur, resulting in higher emissions of $\mathrm{CO}$ and VOCs.

\subsection{Control Options}

$\mathrm{NO}_{\mathrm{x}}$ control has been the primary focus of emission-control research and development in recent years. The traditional method for limiting $\mathrm{NO}_{\mathrm{x}}$ formation has been to control peak flame temperature by injecting diluents (water or steam) or by maintaining homogenous fuel-to-air ratios that keep local flame temperatures below the stoichiometric adiabatic flame temperature. In older, diffusion-flame combustors, fuel/air mixing and combustion occur simultaneously. This results in local fuel/air mixture ratios that produce high local flame temperatures. These "hot spots" are where most of the $\mathrm{NO}_{\mathrm{x}}$ emissions originate. Many new gas turbines feature lean premixed combustion systems. These systems, sometimes referred to as dry low $\mathrm{NO}_{\mathrm{x}}(\mathrm{DLN})$ or dry low emissions (DLE), operate in a tightly controlled lean (low fuel-to-air ratio) premixed mode that maintains modest peak flame temperatures. The following provides a description of the most prominent emission-control approaches:

\section{Diluent Injection}

The first technique used to reduce $\mathrm{NO}_{\mathrm{x}}$ emissions was injection of water or steam into the hightemperature zones of the flame. Both water and steam are strong diluents that can reduce $\mathrm{NO}_{\mathrm{x}}$ emissions by quenching hot spots in the flame. However, positioning of the injection is not precise and some $\mathrm{NO}_{\mathrm{x}}$ is still created. Depending on uncontrolled $\mathrm{NO}_{\mathrm{x}}$ levels, water or steam injection can reduce $\mathrm{NO}_{\mathrm{x}}$ emissions by $60 \%$ or more. Water or steam injection enables gas turbines to operate on natural gas with $\mathrm{NO}_{\mathrm{x}}$ levels as low as 25 ppm $\left(@ 15 \% \mathrm{O}_{2}\right)$. $\mathrm{NO}_{\mathrm{x}}$ is only reduced to 42 to $75 \mathrm{ppm}$ when firing with liquid distillate fuel. Both water and steam increase the mass flow through the turbine, which creates a small amount of additional power. Use of exhaust heat to raise the steam also increases overall efficiency slightly. The water used for either approach needs to be demineralized thoroughly to avoid forming deposits and corrosion in the turbine expansion section. This adds cost and complexity to the operation of the turbine.

\section{Lean Premixed Combustion}

As discussed earlier, thermal $\mathrm{NO}_{\mathrm{x}}$ formation is a function of both flame temperature and residence time. The focus of combustion improvements of the past decade was to lower flame hot-spot temperatures by using lean fuel/air mixtures. Lean combustion decreases the fuel/air ratio in the zones where $\mathrm{NO}_{\mathrm{x}}$ is produced so that peak flame temperature is less than the stoichiometric adiabatic flame temperature, thereby suppressing thermal $\mathrm{NO}_{\mathrm{x}}$ formation.

Lean premixed combustion (DLN/DLE) premixes the gaseous fuel and compressed air so that there are no local zones of high temperatures, or "hot spots," where high levels of $\mathrm{NO}_{\mathrm{x}}$ would form. Lean premixed combustion requires specially designed mixing chambers and mixture inlet 
zones to avoid flashback of the flame. $\mathrm{NO}_{\mathrm{x}}$ levels as low as $9 \mathrm{ppm}$ have been achieved with lean premixed combustion. However, few DLN combustors have reached the level of practical operation necessary for commercialization - the capability of maintaining 9 ppm across a wide operating range from full power to minimum load. One reason is that pilot flames, which are small diffusion flames and a source of $\mathrm{NO}_{\mathrm{x}}$, are usually used for continuous internal ignition and stability in DLN combustors and make it difficult to maintain full net $\mathrm{NO}_{\mathrm{x}}$ reduction over the complete turndown range.

Noise also can be an issue in lean premixed combustors because acoustic waves form due to combustion instabilities when the premixed fuel and air are ignited. This noise also manifests itself as pressure waves, which can damage combustor walls and accelerate the need for combustor replacement, thereby adding to maintenance costs and lowering unit availability.

All leading gas turbine manufacturers feature DLN combustors in at least parts of their product lines. Turbine manufacturers generally guarantee $\mathrm{NO}_{\mathrm{x}}$ emissions of 25 to $42 \mathrm{ppm}$ using this technology. A few models (primarily those larger than $40 \mathrm{MW}$ ) have combustors capable of 9 ppm over the expected range of operation.

The development of market-ready DLN-equipped turbine models is an expensive undertaking because of the operational difficulties in maintaining reliable gas turbine operation over a broad power range. Optimized application of DLN requires an integrated approach to combustor and gas turbine design. Therefore, the timing of applying DLN to multiple turbine product lines is governed by market priorities and resource constraints. Gas turbine manufacturers initially develop DLN combustors for the gas turbine models that have the greatest market opportunity. As time goes on and experience is gained, the technology is expected to be extended to additional models.

\section{Selective Catalytic Reduction}

The primary post-combustion $\mathrm{NO}_{\mathrm{x}}$ control method used today is selective catalytic reduction (SCR). Ammonia is injected into the flue gas and reacts with $\mathrm{NO}_{\mathrm{x}}$ in the presence of a catalyst to produce nitrogen and water vapor. The SCR system is located in the exhaust path, typically within the HRSG, where the temperature of the exhaust gas matches the desired operating temperature of the catalyst. Conventional SCR systems operate at $400^{\circ} \mathrm{F}$ to $800^{\circ} \mathrm{F}$. The cost of conventional SCR has dropped significantly over time. Catalyst innovations have been a principal driver, resulting in a $20 \%$ reduction in catalyst volume and cost with no change in performance.

Low-temperature SCR, operating in the $300^{\circ} \mathrm{F}$ to $400^{\circ} \mathrm{F}$ range, was commercialized in 1995 and is currently in operation on approximately 20 gas turbines. Low temperature SCR is ideal for retrofit applications, where it can be located downstream of the HRSG, avoiding a potentially expensive retrofit of the HRSG to place the catalyst within a hotter zone inside the HRSG.

High-temperature SCR installations, operating in the $800^{\circ} \mathrm{F}$ to $1100^{\circ} \mathrm{F}$ range, have increased significantly in recent years. The high operating temperature permits the catalyst to be placed directly downstream of the turbine exhaust flange. High-temperature SCR is also used on base- 
loaded simple-cycle gas turbines where there is no HRSG. SCR reduces $80 \%$ to $90 \%$ of the $\mathrm{NO}_{\mathrm{x}}$ in the gas turbine exhaust, depending on the degree to which the chemical conditions in the exhaust are uniform. When used in series with water/steam injection or DLN combustion, SCR can result in low single-digit $\mathrm{NO}_{\mathrm{x}}$ levels ( 3 to $5 \mathrm{ppm}$ ).

SCR systems are expensive and significantly affect the economic feasibility of smaller gas turbine projects. SCR requires on-site storage of ammonia, a hazardous chemical. In addition, ammonia can "slip" through the process unreacted, contributing to environmental health concerns. $^{16}$

\section{Carbon Monoxide Oxidation Catalysts}

$\mathrm{CO}$ in gas turbine exhaust is typically controlled with oxidation catalysts. Some SCR installations incorporate $\mathrm{CO}$ oxidation modules along with $\mathrm{NO}_{\mathrm{x}}$ reduction catalysts for simultaneous control of $\mathrm{CO}$ and $\mathrm{NO}_{\mathrm{x}}$. The $\mathrm{CO}$ catalyst promotes the oxidation of $\mathrm{CO}$ and hydrocarbon compounds to carbon dioxide and water as the exhaust stream passes through the catalyst bed. The oxidation takes place spontaneously, so no reactants are required. The catalyst is usually a precious metal such as platinum, palladium, or rhodium. Other formulations, such as metal oxides, are used for emission streams that contain chlorinated compounds. CO catalysts are also used to destroy hazardous organic air pollutants and other VOCs. CO catalysts on gas turbines achieve approximately $90 \%$ destruction of $\mathrm{CO}$ and $85 \%$ to $90 \%$ destruction of formaldehyde (similar reductions can be expected for other VOCs).

\section{Catalytic Combustion}

In catalytic combustion, fuel is oxidized at very lean conditions in the presence of a catalyst. Catalytic combustion is a flameless process, allowing fuel oxidation to occur at temperatures below $1,700^{\circ} \mathrm{F}$, where very little $\mathrm{NO}_{\mathrm{x}}$ is formed. The catalyst is applied to combustor surfaces and causes the fuel-air mixture to react and release its initial thermal energy. The combustion reaction in the lean premixed gas then goes to completion at the design temperature. Catalytic combustors are being developed to control $\mathrm{NO}_{\mathrm{x}}$ emissions down to less than $3 \mathrm{ppm}$. Data from ongoing long-term testing indicates that catalytic combustion exhibits low vibration and acoustic noise, only one-tenth to one-hundredth the levels measured in the same turbine equipped with DLN combustors.

Gas turbine catalytic combustion technology is being pursued by developers of combustion systems and gas turbines and by government agencies, most notably the U.S. Department of Energy and the California Energy Commission. Past efforts at developing catalytic combustors for gas turbines achieved low, single-digit-ppm $\mathrm{NO}_{\mathrm{x}}$ levels, but failed to produce combustion systems with suitable operating durability. This was typically due to cycling damage and the

\footnotetext{
${ }^{16}$ The SCR reaction, with stoichiometric (for $\mathrm{NO}_{\mathrm{x}}$ reduction) ammonia or other reagent, should eliminate all $\mathrm{NO}_{\mathrm{x}}$. However, because of imperfect mixing in the combustor, the $\mathrm{NO}_{\mathrm{x}}$ is not uniformly distributed across the turbine exhaust. Additionally, the ammonia, or other reagent is not injected in a precisely uniform manner. These two nonuniformities in chemical composition cause either excess ammonia to be used and to consequently "slip" out the exhaust, or incomplete reaction of the $\mathrm{NO}_{\mathrm{x}}$ in the turbine exhaust.
} 
brittle nature of the materials used for catalysts and catalyst supports. Catalytic combustor developers and gas turbine manufacturers are testing durable catalytic and "partial catalytic" systems that are overcoming the problems of past designs. Catalytic combustors capable of achieving $\mathrm{NO}_{\mathrm{x}}$ levels below $3 \mathrm{ppm}$ are in full-scale demonstration and are entering early commercial introduction ${ }^{17}$. Similar to DLN combustion, optimized catalytic combustion requires an integrated approach to combustor and turbine design.

\section{SCONOx ${ }^{\mathrm{TM}}$ Catalytic Absorption System}

SCONOx ${ }^{\mathrm{TM}}$, patented by Goaline Environmental Technologies, is a post-combustion alternative to SCR that has been demonstrated to reduce $\mathrm{NO}_{\mathrm{x}}$ emissions to less than $1 \mathrm{ppm}$ and remove almost $100 \%$ of the CO. SCONOx ${ }^{\mathrm{TM}}$ combines catalytic conversion of $\mathrm{CO}$ and $\mathrm{NO}_{\mathrm{x}}$ with an absorption/regeneration process that eliminates the ammonia reagent found in SCR technology. It is based on a unique integration of catalytic oxidation and absorption technology. $\mathrm{CO}$ and $\mathrm{NO}$ are catalytically oxidized to $\mathrm{CO}_{2}$ and $\mathrm{NO}_{2}$. The $\mathrm{NO}_{2}$ molecules are subsequently absorbed on the treated surface of the $\mathrm{SCONOx}{ }^{\mathrm{TM}}$ catalyst. The system does not require the use of ammonia, avoiding the potential for ammonia slip associated with SCR. The SCONOx ${ }^{\mathrm{TM}}$ system is generally located within the HRSG and, under special circumstances, may be located downstream of the HRSG. The system operates between $300-700^{\circ} \mathrm{F}$. SCONOx ${ }^{\mathrm{TM}}$ was identified as "Lowest Achievable Emission Rate (LAER)" technology for gas turbine $\mathrm{NO}_{\mathrm{x}}$ control by U.S. EPA Region 9 in 1998.

\subsection{System Emissions}

Table 6 shows typical emissions for each of the five typical turbine systems for the base year (2003). The emissions are based on gas turbine exhaust with no exhaust treatment and reflect what manufacturers will guarantee at this time, using commercially available technology.

Due to the uniqueness of the combustion system of each gas turbine model, clear distinctions need to be made when discussing emissions technology and the corresponding emissions levels. Those distinctions are technology that is commercially available, technology that is technically proven but not yet commercial, and technology that is technically feasible but neither technically proven nor commercially available. These distinctions are more important for the pollution prevention and combustion technologies than for the exhaust treatment control alternatives. The latter two distinctions represent technologies that cannot be considered commercially available.

\footnotetext{
${ }^{17}$ For example, Kawasaki offers a version of their M1A 13X, 1.4 MW gas turbine with a catalytic combustor guaranteed to produce no more than $3 \mathrm{ppm} \mathrm{NO}$.

Gas-Fired Distributed Energy Resource Technology Characterizations Small Gas Turbine Systems - Page 3-26
} 


\section{Table 6. Gas Turbine Emission Characteristics (Without Exhaust-Control Options*)}

\begin{tabular}{|l|c|c|c|c|c|}
\hline Emissions Characteristics & $\begin{array}{c}\text { System } \\
\mathbf{1}\end{array}$ & $\begin{array}{c}\text { System } \\
\mathbf{2}\end{array}$ & $\begin{array}{c}\text { System } \\
\mathbf{3}\end{array}$ & $\begin{array}{c}\text { System } \\
\mathbf{4}\end{array}$ & $\begin{array}{c}\text { System } \\
\mathbf{5}\end{array}$ \\
\hline Nominal Capacity (MW) & 1 & 5 & 10 & 25 & 40 \\
\hline Electrical Efficiency (\%), HHV & 22 & 27 & 29 & 34 & 37 \\
\hline $\mathrm{NO}_{\mathrm{x}},\left(\mathrm{ppm} @ 15 \% \mathrm{O}_{2}\right)$ & $42^{18}$ & $25^{19,20}$ & 25 & $25^{18}$ & 25 \\
\hline $\mathrm{NO}_{\mathrm{x}},(\mathrm{lb} / \mathrm{MWh})^{21}$ & 2.4 & 1.1 & 1.0 & 0.9 & 0.8 \\
\hline $\mathrm{CO},(\mathrm{ppmv})^{22}$ & 20 & 20 & 20 & 20 & 20 \\
\hline $\mathrm{CO},(\mathrm{lb} / \mathrm{MWh})$ & 0.7 & 0.6 & 0.5 & 0.4 & 0.4 \\
\hline $\mathrm{CO}_{2},(\mathrm{lb} / \mathrm{MWh})$ & 1,825 & 1,475 & 1,375 & 1,165 & 1,080 \\
\hline
\end{tabular}

* For typical systems commercially available in 2003. Emissions estimates are for untreated turbine exhaust conditions $\left(15 \% \mathrm{O}_{2}\right.$, no SCR or other exhaust clean-up). Estimates are based on typical manufacturers' guarantees using commercially available DLN combustion technology.

Add-on control options for $\mathrm{NO}_{\mathrm{x}}$ and $\mathrm{CO}$ can further reduce the emissions of each by $80 \%$ to $90 \%$. For many distributed generation gas turbine installations, exhaust treatment options have, for the most part, been avoided or not implemented due to their negative impacts on capital and operating costs.

\subsection{Key Technology Objectives}

This section describes the significant component improvements that gas turbine manufacturers are pursuing to enhance energy efficiency, control costs, and maintain high reliability, availability, and maintainability. The emissions section describes manufacturers' efforts to develop low-emissions combustion technologies. Trends in gas turbine technology development in sizes of more than $3 \mathrm{MW}$ reflect a continuous drive toward simultaneously achieving low cost, high efficiency, and the lowest possible emissions. Efforts to achieve higher thermal efficiencies and single-digit emission levels without post-combustion treatment focus on advances in blade

\footnotetext{
${ }^{18} 42 \mathrm{ppm}$ represents typical guaranteed state-of -the-art for $1 \mathrm{MW}$ gas turbine systems. It has just been announced that Kawasaki is offering their M1A-13A equipped with a Xonon catalytic combustion system provided by Catalytica Energy Systems, with a guarantee of less than $3 \mathrm{ppm} \mathrm{NO}_{\mathrm{x}}$. Many of the other models in this size range do not have DLN options and still utilize diffusion flame combustors.

${ }^{19}$ Solar Turbines has received permits for a $5 \mathrm{MW}$ turbine guaranteed for $15 \mathrm{ppm} \mathrm{NO}_{\mathrm{x}}$. This gas turbine is equipped with a developmental ceramic combustor liner that is not standard on the commercial product line.

${ }^{20} \mathrm{SCONOx}^{\mathrm{TM}}$ has been in operation on a General Electric LM2500 in the Los Angeles area since 1996. A second SCONOx ${ }^{\mathrm{TM}}$ system is installed on a Solar Centaur 50 turbine in Massachusetts.

${ }^{21}$ Conversion from volumetric emission rates (ppmv at $\left.15 \% \mathrm{O}_{2}\right)$ to output-based rates $(\mathrm{lbs} / \mathrm{MWh})$ for both $\mathrm{NO}_{\mathrm{x}}$ and $\mathrm{CO}$ was based on conversion multipliers provided by Catalytica Energy Systems (http://www.catalyticaenergy.com/xonon/emissions_factors.html).

${ }^{22} \mathrm{CO}$ catalytic oxidation modules on gas turbines reduce CO levels by approximately $90 \%$. Recent permits have used $\mathrm{CO}$ oxidation catalysts to achieve less than $5 \mathrm{ppm} \mathrm{CO}$.
}

Gas-Fired Distributed Energy Resource Technology Characterizations Small Gas Turbine Systems - Page 3-27 
design, cooling techniques, ceramic materials, and combustion modifications including "ultralean" premix (dry low $\mathrm{NO}_{\mathrm{x}}$ ) and catalytic combustion.

Turbines smaller than $3 \mathrm{MW}$ face a unique set of technical and competitive issues. Competition from reciprocating engines is intense in this size range, affecting investment decisions and technology objectives. Microturbines are already available in $250 \mathrm{~kW}$ capacity, and $400 \mathrm{~kW}$ to $500 \mathrm{~kW}$ microturbines are under development. As microturbines increase in size they will also start to compete with more traditional gas turbine technology. Although the features offered in microturbines, such as recuperation and dry-low-NOx combustion may migrate into larger gas turbines, turbines much smaller than $3 \mathrm{MW}$ have unique problems of their own, including limited firing temperatures. Small turbines and microturbines use radial flow components, which face more difficult technical challenges in implementing internal cooling of the expansion turbine ${ }^{23}$. However, some of the disadvantages of using radial components may be overcome with cycle advances, such as the intercooled and recuperated cycles discussed earlier in Section 4.

The following paragraphs describe the technology objectives and options being pursued by manufacturers, government, and component suppliers for gas turbines in the 3 to $40 \mathrm{MW}$ size range:

\section{Increased Turbine Inlet Temperature}

Gas turbine efficiency and power increase with higher firing temperature. Increased power results in lower cost per $\mathrm{kW}$, provided that the cost of the technology needed to increase the firing temperature is economic and that the current high levels of system durability, reliability, availability, and maintainability are not compromised. Manufacturers are pursuing advances in several critical components to accommodate higher firing temperatures.

The most critical limitations on firing temperature are embodied in the combined thermal and mechanical design of the gas turbine blades and vanes. The design and manufacture of gas turbine blades and vanes involves:

1) Economic selection of materials for a combination of high strength at elevated temperature and manufacturability.

2) Heat transfer analysis of the component with internal cooling and surface thermal protection coating so that the creep (slow stretching under tensile forces at high temperature) limit of the material is not exceeded during operation.

\footnotetext{
${ }^{23}$ Microturbines typically use radial flow components because, in smaller sizes, radial flow components are less sensitive to clearances and are better suited for the specific speeds typically required in small gas turbines. Radial flow components are typically thought of being lower cost than similar axial flow components, but creative designs can reduce the cost of axial flow components. It is generally more difficult to operate at higher firing temperatures with radial flow components. Although cooling can be implemented in the stationary radial flow nozzle vanes, it is much more difficult to cool the rotor and blades. An alternative approach would be to use ceramic nozzles and vanes, but as the size of the radial rotor increases so does the probability of flaws in the casting. Current casting and flaw detection technology for ceramics limit the size of ceramic radial turbines making a ceramic axial flow turbine more preferable over a radial flow turbine once the engine turbine reaches a critical size.
}

Gas-Fired Distributed Energy Resource Technology Characterizations Small Gas Turbine Systems - Page 3-28 
Firing temperature is also limited by $\mathrm{NO}_{\mathrm{x}}$ emissions targets, because higher firing temperatures invariably increase $\mathrm{NO}_{\mathrm{x}}$ emissions.

The mechanical integrity of hot section components (combustor, transition pieces, and turbine blades and vanes) is critical. As firing temperature increases, the thermal stresses on the combustor and transition piece to the power turbine increase. The transition piece is the component that ducts the combustor exit gases into the first-stage turbine vanes. The increase in temperature of such structural components is a major concern in achieving reliable operation. While the alloys used for these components have advanced little in recent times, the manufacturing process has improved significantly. Turbine blades and vanes are now made by directional casting and single-crystal solidification casting processes that increase their hightemperature capability. As firing temperature increases, the heat load on the combustor walls also increases rapidly, adding the combustor to the list of critical hot-section components. Because of the effect of temperature cycling on the life of hot-section parts, gas turbines are usually rated for either continuous duty (long life) or for emergency or peaking duty.

\section{Compressor and Turbine Blades and Vanes}

\section{Aerodynamics}

Compressor and turbine blade and vane aerodynamic efficiencies are important in obtaining the highest system efficiency. Industry, government, and university researchers have been working to improve the shapes of blades and vanes. These advances usually begin commercial service on new gas turbine models entering the market. Later, these improvements in component efficiency are incorporated into existing machines as upgrades.

Three-dimensional computational fluid dynamics analysis has helped to increase the efficiency of these aerodynamic components, thereby reducing aerodynamic losses and increasing overall machine efficiency. The newest advances include three-dimensional blade and vane profiling to reduce losses attributable to secondary flows occurring in boundary layers. Such blades and vanes have tailored radial contouring.

\section{Internal Cooling}

Gas turbine efficiency and power increase with increasing turbine inlet temperature. However, turbine blade and vane materials have well-defined temperature limitations consistent with long life and safe operation. In order to increase the turbine inlet temperature without overheating the materials, manufacturers have introduced internal cooling into the design of blades and vanes. A small, engineered percentage of the high-pressure air from the compressor is diverted to the expansion turbine section and used to cool the turbine disks holding the blades. The air passes through a network of precise holes and flow passages inside the blades and vanes, cooling them; it then passes into the main flow at the downstream end of the blade or vane. Internal cooling of the blades and vanes reduces both their average and local maximum temperatures.

Detailed knowledge of heat transfer coefficients over surfaces and within flow passages allows judicious design of blades and vanes as heat exchangers. This design allows the temperature of the gas expanding in the turbine to be increased while keeping the material at or below its safe long-life design temperature. The use of compressor air for cooling reduces the mass flow 
through that stage of the turbine and, consequently, slightly reduces power. When the tradeoff is complete, the appreciable increases in turbine gas flow temperature result in substantial gains in both power and efficiency.

Turbine blade and vane cooling was developed for aircraft gas turbines where the additional power is vital to increasing an airplane's top speed and acceleration. Over time, cooling became available for stationary gas turbines and was disseminated through engineering technical papers and the migration of aircraft gas turbine engineers to stationary turbine manufacturing. Cooling is now appearing in smaller gas turbines, where product economics had previously precluded the level of investment in advanced technology development that is economic for larger machines.

\section{Thermal Barrier Coatings}

Another technology that allows increased temperature of the expansion gas without overheating blade and vane materials is surface coating of the materials that are exposed to high temperature and have some degree of internal cooling. These surface barrier coatings are generally ceramic and provide both corrosion resistance and thermal protection. The coatings are capable of sustained life at elevated temperature. With internal cooling, a heat flux through the material exists. This heat flux results in temperature drops through the coating on the surfaces and in the surface (gas) boundary layer. Unfortunately these coatings have been limited to thin layers, as their differential thermal expansion is quite different from that of the substrate metal, and thick coatings tend to separate from the base. However, because adequate protection is afforded with thin sections, the use of such thermal barrier coatings is an established practice.

\section{Ceramic Materials}

Ceramic materials that retain structural integrity to temperatures in the $2100-2400^{\circ} \mathrm{F}$ range have been the subject of research and development for decades. Researchers have created small radial inflow turbines from structural ceramic material for possible use in automotive gas turbines. One may expect to find ceramic materials in use in industrial gas turbines in the future, first on vanes and then on blades in the expansion turbines. The benefit of using ceramics is that vane and blade cooling need not be used. This reduces the extra cost of building vanes and blades with complex internal structures, and eliminates the need for some of the compressor air to be used for cooling. With more air flowing through the combustor, more power can be generated in the first turbine stages, with resulting gains in both power and efficiency.

Monolithic structural ceramics for gas turbine applications have matured greatly during the past 35 years. The ceramic materials available at the beginning of the 1970s in the United States were reaction-bonded silicon nitride, hot-pressed silicon nitride, and reaction-sintered silicon carbide, primarily based on technology developed in Great Britain during the 1960s. These materials were relatively weak (particularly at elevated temperatures), exhibited poor fracture toughness, and were subject to time-dependent failure (creep rupture and slow crack growth). Continued improvements in powder synthesis, processing, and densification have resulted in the development of the current generation of silicon nitride ceramics, which have controlled microstructures consisting of elongated grains.

Similar progress has been made in the areas of (1) component design and fabrication, (2) probabilistic design methodologies for predicting component life, and (3) nondestructive 
evaluation of complex-shaped parts. Because of these developments, monolithic ceramic components (blades and vanes) have accumulated thousands of hours in gas turbine engine demonstration programs.

During the early 1980s, composite ceramics reinforced with high-strength ceramic fibers started to become available. One of the earliest was a $\mathrm{SiC} / \mathrm{SiC}$ composite from the Société Européenne de Propulsion (SEP) in France. The early SiC-based ceramic matrix composites degraded at high temperature in oxidizing environments, so they were initially considered only for short life applications. However, by about 1992, the ceramic composite technology had progressed far enough that the "Continuous Fiber Ceramic Composite" program was started by the U.S. Department of Energy (DOE) to accelerate ceramic composite development. Another DOEfunded program, the "Ceramic Stationary Gas Turbine" (CSGT) development program at Solar Turbines, Inc., evaluated some of the resulting composite materials and other ceramic composite materials as combustor liners in combustor tests and later in actual engines. After several development iterations, $\mathrm{SiC} / \mathrm{SiC}$ ceramic composite combustor liners have now survived more than 15,000 hours under normal turbine operating conditions.

Despite the experience base described above, a number of challenges remain before monolithic and composite ceramics demonstrate the long lifetimes required for turbine applications. The first challenge is that of environmental degradation. The aforementioned field tests have shown that three processes can affect performance of the monolithic ceramics: (1) localized corrosion due to the presence of reactive species in the environment, (2) environmentally induced destabilization of the intergranular phases, and (3) rapid recession of the silicon nitride (or silicon carbide) due to loss of its protective silica scale by direct reaction with water vapor. This has led to the development of oxide-based environmental barrier coatings, which are at an early stage of development and are the subject of substantial component and engine testing. The second challenge, which is specific for monolithics, is that of impact resistance. Further improvements in fracture toughness may be required to ensure high reliability in the presence of foreign object damage.

\section{Sensors, Controls, Diagnostic Software, and Supporting Technologies}

While the major focus of gas turbine development is on increasing efficiency and power, there is substantial economic incentive, and technology opportunity, to develop and improve a number of system components and technologies whose function is to increase unit availability and to sustain operation with minimum emissions and minimize likelihood of forced outage (emergency shutdown). Some enhancements involve increased use of instruments and sensors to monitor the performance and the condition of the gas turbine and its supporting systems (such as lubrication and fuel gas booster compressor), combined with a condition monitoring and predictive maintenance software system to advise on ordering spare parts, scheduling downtime for preventive maintenance, and gas turbine operation for desired availability. With the current requirement for low levels of emissions, and the potential for further tightening of emissions requirements, there also is a need for increased feedback from the emissions systems into the operating system to permit operators to include emissions considerations in their operation and dispatch decisions. While the technology advancements for these auxiliary systems is not as dramatic as those of advancing firing temperature, such advances can improve the operating 
economics of gas turbines and thereby support justification of higher-performing, higher-priced machines on the basis of owner return on investment.

\subsection{Advanced Technology Projections}

\section{Gas Turbine Technology Development Factors}

Gas turbines smaller than 2 to $3 \mathrm{MW}$ face intense competition from reciprocating engines on the basis of both cost and efficiency. Engine markets such as emergency gensets and standby units provide sales volumes that afford economies of scale in engine manufacturing and service, further reducing costs of competing engine systems. Competition from reciprocating engines is expected to become even more intense as the emissions from engines in the $500 \mathrm{~kW}$ to $3 \mathrm{MW}$ size range are reduced through RD\&D efforts. Consequently, there is appreciable uncertainty regarding the path of future development for gas turbines smaller than $3 \mathrm{MW}$. From a purely technical perspective, large improvements in performance are possible through the use of internally cooled nozzles and blades with axial flow expansion turbines. Performance of recuperated turbines can be improved by advances in recuperator materials and design methodology. Power-generation efficiencies could improve from their present level of the low 20 s to levels in the upper 20s, and possibly lower 30s, with application of the technology in practical use on larger gas turbines. As discussed in Section 6, performance of turbines in this size range could also be improved through the introduction of technologies used in microturbines. However, while advanced technology could improve performance and emissions, it is less clear that advanced technology could lower costs enough to materially improve ownership economics. Consequently, as the business prospects are uncertain for products, in this smaller size range, of higher efficiency but higher cost, it is difficult to predict investment levels in the development of improved products in this size range.

Turbines ranging from 3 to $10 \mathrm{MW}$ face attractive prospects for increased sales and moderate investments in technology improvements. These turbines compete well with similarly sized reciprocating engines in many applications. Significant gains in efficiency and specific power are expected through higher turbine inlet temperatures, and associated higher optimum pressure ratios. The introduction of ceramics or improved internal cooling of nozzles and blades, or a combination of the two technologies, can be expected in this size range depending on individual manufacturer's approaches and specific product requirements. Since the rate of progress in performance improvements will be set by the prospects for increased sales and profits from improved products, the projections for product improvement of turbines in this size range are based partially on business expectations and partially on technology advances.

Gas turbines of more than $10 \mathrm{MW}$ are of two heritages - industrial and aeroderivative. The aeroderivative machines are gas turbines made for aeronautical applications that are taken off the assembly line and modified for stationary use. Their efficiency and performance are basically determined by the needs of the aeronautical market. The industrial gas turbines in this size range can adopt much of the technology developed for aeronautical applications, provided that business conditions support acceptable returns on investment for such development activity. Gas turbines of this size also can be expected to benefit from some of the technologies developed for the larger " $\mathrm{H}$ " class machines, with partial support from DOE through the Advanced Turbine 
Systems (ATS) program. The use of ceramic hot-section components, nozzles, blades and combustors; or improved internal cooling of nozzles and blades; or a combination of the two technologies can be expected, depending on individual manufacturer's approaches and specific product requirements. Again, improvements are likely to develop through small, low-risk steps consistent with the past experience of this size turbine.

\section{Technology Projections}

Several classes of improvements can be expected in gas turbines between 3 and $40 \mathrm{MW}$ in size over the timeframe of this report (2030):

- System heat rates will decline (efficiencies increase) due to advances in turbine blade and vane design; improved tip sealing of rotating blades; and the use of advanced, hightemperature materials such as monolithic ceramics and ceramic thermal barrier coatings. Improvements will occur over time, due in part to the diffusion of technology from aircraft turbines to those for stationary power, and the improvement may accelerate with the use of ceramic materials. With increasing temperatures, manufacturers will also increase pressure ratios and obtain corresponding increases in power and decreases in cost per $\mathrm{kW}$.

- Emissions control will be improved with catalytic combustion or other combustion enhancements that allow more economic operation of gas turbine systems than is possible with exhaust gas-treatment approaches.

- More effective packaging and integration of systems and controls will reduce the cost of the basic components. Installation costs will be reduced by greater standardization of design and auxiliary components. A modular approach with greater factory assembly will greatly reduce site costs, particularly for smaller systems.

- The cost of installing CHP plants will decline, as states adopt streamlined siting, interconnection, and permitting procedures that allow for greater standardization of CHP components and packages. These changes in government policy will allow beneficial changes in technology and reductions in lead times.

Table 7 shows estimates of the future performance of four representative gas turbine CHP systems - 5 MW, $10 \mathrm{MW}, 25 \mathrm{MW}$, and $40 \mathrm{MW}$. The out-year performance projections for 2005, 2010, 2020, and 2030 are based on many of the technology and learning curve advances listed above. Advances specifically incorporated into the projections include:

The efficiency of industrial turbines will improve through the use of: 1) improved internal cooling and the use of ceramic materials for turbine vanes and blades; 2) improved aerodynamic efficiency of vanes and blades (with component profiles resulting from more comprehensive three-dimensional compressible fluid dynamic analyses); 3 ) improved thermal barrier coatings; and 4) improved tip sealing. Improvements will be the result of a diffusion of knowledge developed for larger, higher-technology applications to smaller industrial machines, rather than engineering breakthroughs.

Improvements in internal cooling and design and the use of advanced materials will result in gradual increases in firing temperatures and pressure ratios for the turbines of interest. 
Larger improvements on a relative basis are expected for the smaller turbines as the technology deployed in larger, more sophisticated turbines is extended to smaller machines.

In addition to efficiency improvements, the specific power will increase about $20 \%$ for the gas turbines of interest by 2020. Higher firing temperatures will increase power output. Additionally, pressure ratio increases will be achieved by adding stages ahead of the first stage of the compressor ("zero staging"). This will increase the mass flow through the gas turbines, further increasing the power output. These two related design advances result in both a power increase and a decrease in cost per $\mathrm{kW}$.

- System package costs for gas turbines will fall by $10-25 \%$ due to a relatively robust market, based in part on increased reliance on distributed generation as a critical part of the nation's power infrastructure. Increased competition and standardized computer-aided design will result in lower-cost systems. This effect will be partially offset by the use of more expensive materials such as ceramics and noble metal catalysts.

Electrical equipment costs will be reduced significantly due to a favorable regulatory and policy environment for on-site and distributed generation and improvements in interconnection technology, especially for smaller units. This environment will lead to a $40 \%$ reduction in electrical equipment costs for $5 \mathrm{MW}$ systems and a $20 \%$ reduction for 40 MW systems.

Other system costs will decline over time as follows: HRSG (15\% to $25 \%$ ), water treatment systems ( $10 \%$ to $20 \%$ ), and other equipment ( $25 \%$ for $5 \mathrm{MW}$ to $10 \%$ for $40 \mathrm{MW})$. The higher reductions in the smaller sizes will be due to the improvement in packaging and systems integration that will reduce the on-site construction requirements.

Materials and labor; engineering, project and construction management; and project contingencies will decline in proportion to the reduction in capital costs.

$\mathrm{NO}_{\mathrm{x}}$ emissions will be reduced to an engine-out level of $5 \mathrm{ppm}$ in 2010 through advanced combustion techniques or the introduction of catalytic combustion. 
Table 7. Current and Advanced Combustion Turbine System Characteristics ${ }^{24}$

\begin{tabular}{|c|c|c|c|c|c|}
\hline \multicolumn{6}{|l|}{$\begin{array}{l}\text { Cost and Performance Projections, } \\
5 \text { MW Gas Turbine CHP System }\end{array}$} \\
\hline Year & Current & 2005 & 2010 & 2020 & 2030 \\
\hline Total Installed Cost (2003 \$/kW) & 1,024 & 970 & $\$ 900$ & $\$ 840$ & $\$ 810$ \\
\hline O\&M Costs (2003 \$/kWh) & 0.006 & 0.006 & 0.005 & 0.005 & 0.005 \\
\hline Electrical Heat Rate (Btu/kWh) & 12,590 & 12,015 & 11,375 & 10,500 & 9,750 \\
\hline Electric Efficiency (\%) & 27 & 28 & 30 & 33 & 35 \\
\hline Fuel Input (MMBtu/hr) & 62.9 & 60.1 & 56.9 & 52.5 & 48.7 \\
\hline \multicolumn{6}{|l|}{ CHP Characteristics } \\
\hline Total CHP Efficiency & 67 & 68 & 69 & 71 & 72 \\
\hline Steam Output (MMBtu/hr) & 25.0 & 23.9 & 22.4 & 20.3 & 18.0 \\
\hline Heat/Fuel Ratio & 0.40 & 0.40 & 0.39 & 0.39 & 0.37 \\
\hline Power/Heat Ratio & 0.68 & 0.71 & 0.76 & 0.84 & 0.95 \\
\hline Net Heat Rate (Btu/kWh) & 6,343 & 6,038 & 5,783 & 5,446 & 5,244 \\
\hline \multicolumn{6}{|l|}{ Emissions Characteristics } \\
\hline $\mathrm{NO}_{\mathrm{x}}(\mathrm{ppm})$ & 25 & 15 & 5 & 3 & 3 \\
\hline $\mathrm{NO}_{\mathrm{x}}(\mathrm{lb} / \mathrm{MWh})$ & 1.1 & 0.6 & 0.2 & 0.1 & 0.1 \\
\hline $\mathrm{CO}(\mathrm{ppm})$ & 20 & 20 & 15 & 15 & 15 \\
\hline $\mathrm{CO}(\mathrm{lb} / \mathrm{MWh})$ & 0.6 & 0.5 & 0.4 & 0.4 & 0.3 \\
\hline $\mathrm{CO}_{2}(\mathrm{lb} / \mathrm{MWh})$ & 1,475 & 1,405 & 1,330 & 1,230 & 1,140 \\
\hline
\end{tabular}

\footnotetext{
${ }^{24}$ The current year $5 \mathrm{MW}$ system is based on the Solar Taurus 60; the $10 \mathrm{MW}$ system is based on the Solar Mars 100; the 25 MW system is based on the GE LM2500; the 40 MW system is based on the GE LM6000.

Gas-Fired Distributed Energy Resource Technology Characterizations

Small Gas Turbine Systems - Page 3-35
} 
Table 7 (cont'd.) Current and Advanced Combustion Turbine System Characteristics

\begin{tabular}{|c|c|c|c|c|c|}
\hline \multicolumn{6}{|l|}{$\begin{array}{l}\text { Cost and Performance Projections, } \\
10 \text { MW Gas Turbine CHP System }\end{array}$} \\
\hline Year & Current & 2005 & 2010 & 2020 & 2030 \\
\hline Total Installed Cost $(2003 \$ / \mathrm{kW})$ & 928 & 900 & 860 & 790 & 760 \\
\hline O\&M Costs (2003 \$/kWh) & 0.006 & 0.005 & 0.005 & 0.005 & 0.004 \\
\hline Electrical Heat Rate (Btu/kWh) & 11,765 & 11,300 & 10,800 & 9,950 & 9,350 \\
\hline Electric Efficiency (\%) & 29 & 30 & 32 & 34 & 37 \\
\hline Fuel Input (MMBtu/hr) & 117.7 & 113.0 & 108.0 & 99.5 & 93.5 \\
\hline \multicolumn{6}{|l|}{ CHP Characteristics } \\
\hline Total CHP Efficiency & 69 & 69 & 69 & 71 & 72 \\
\hline Steam Output (MMBtu/hr) & 46.5 & 43.5 & 40.8 & 36.4 & 33.4 \\
\hline Heat/Fuel Ratio & 0.40 & 0.39 & 0.38 & 0.37 & 0.36 \\
\hline Power/Heat Ratio & 0.73 & 0.78 & 0.84 & 0.94 & 1.02 \\
\hline Net Heat Rate (Btu/kWh) & 5,953 & 5,853 & 5,696 & 5,402 & 5,174 \\
\hline \multicolumn{6}{|l|}{ Emissions Characteristics } \\
\hline $\mathrm{NO}_{\mathrm{x}}(\mathrm{ppm})$ & 25 & 15 & 5 & 3 & 3 \\
\hline $\mathrm{NO}_{\mathrm{x}}(\mathrm{lb} / \mathrm{MWh})$ & 1.0 & 0.6 & 0.2 & 0.1 & 0.1 \\
\hline $\mathrm{CO}(\mathrm{ppm})$ & 20 & 20 & 15 & 15 & 15 \\
\hline $\mathrm{CO}(\mathrm{lb} / \mathrm{MWh})$ & 0.5 & 0.5 & 0.4 & 0.3 & 0.3 \\
\hline $\mathrm{CO}_{2}(\mathrm{lb} / \mathrm{MWh})$ & 1,375 & 1,320 & 1,265 & 1,165 & 1,095 \\
\hline
\end{tabular}


Table 7 (cont'd.) Current and Advanced Combustion Turbine System Characteristics

\begin{tabular}{|c|c|c|c|c|c|}
\hline \multicolumn{6}{|l|}{$\begin{array}{l}\text { Cost and Performance Projections, } \\
25 \text { MW Gas Turbine CHP System }\end{array}$} \\
\hline Year & Current & 2005 & 2010 & 2020 & 2030 \\
\hline Total Installed Cost $(2003 \$ / \mathrm{kW})$ & 800 & 780 & 755 & 705 & $\$ 680$ \\
\hline O\&M Costs $(2003 \$ / k W h)$ & 0.005 & 0.005 & 0.005 & 0.004 & 0.004 \\
\hline Electrical Heat Rate (Btu/kWh) & 9,945 & 9,665 & 9,225 & 8,865 & 8,530 \\
\hline Electric Efficiency (\%) & 34 & 35 & 37 & 39 & 40 \\
\hline Fuel Input (MMBtu/hr) & 248.7 & 241.6 & 230.5 & 221.6 & 213.3 \\
\hline \multicolumn{6}{|l|}{ CHP Characteristics } \\
\hline Total CHP Efficiency & 70 & 71 & 73 & 73 & 74 \\
\hline Steam Output (MMBtu/hr) & 89.9 & 86.2 & 82.1 & 77.3 & 73.0 \\
\hline Heat/Fuel Ratio & 0.36 & 0.36 & 0.36 & 0.35 & 0.34 \\
\hline Power/Heat Ratio & 0.95 & 0.99 & 1.04 & 1.10 & 1.17 \\
\hline Net Heat Rate (Btu/kWh) & 5,453 & 5,355 & 5,115 & 4,995 & 4,879 \\
\hline \multicolumn{6}{|l|}{ Emissions Characteristics } \\
\hline $\mathrm{NO}_{\mathrm{x}}, \mathrm{ppm}$ & 25 & 15 & 5 & 3 & 3 \\
\hline $\mathrm{NO}_{\mathrm{x}}, \mathrm{lb} / \mathrm{MWh}$ & 0.9 & 0.5 & 0.2 & 0.1 & 0.1 \\
\hline $\mathrm{CO}, \mathrm{ppm}$ & 20 & 20 & 15 & 15 & 15 \\
\hline $\mathrm{CO}, \mathrm{lb} / \mathrm{MWh}$ & 0.4 & 0.4 & 0.3 & 0.3 & 0.3 \\
\hline $\mathrm{CO}_{2}, \mathrm{lb} / \mathrm{MWh}$ & 1,165 & 1,130 & 1,080 & 1,035 & 1,000 \\
\hline
\end{tabular}


Table 7 (cont'd.) Current and Advanced Combustion Turbine System Characteristics

\begin{tabular}{|l|c|c|c|c|c|}
\hline Cost and Performance Projections, \\
40 MW Gas Turbine CHP System & Current & $\mathbf{2 0 0 5}$ & $\mathbf{2 0 1 0}$ & $\mathbf{2 0 2 0}$ & $\mathbf{2 0 3 0}$ \\
\hline Year & 702 & 695 & 680 & 660 & 640 \\
Total Installed Cost (2003 \$/kW) & 0.004 & 0.004 & 0.004 & 0.004 & 0.004 \\
O\&M Costs (2003 \$/kWh) & 9,220 & 9,125 & 8,865 & 8,595 & 8,325 \\
Electrical Heat Rate (Btu/kWh) & 37 & 37 & 39 & 40 & 41 \\
Electric Efficiency (\%) & 368.8 & 364.9 & 354.5 & 343.8 & 332.9 \\
Fuel Input (MMBtu/hr) & & & & & \\
\hline CHP Characteristics & 72 & 72 & 73 & 73 & 74 \\
\hline Total CHP Efficiency & 127.3 & 125.5 & 120.5 & 115.5 & 111.3 \\
Steam Output (MMBtu/hr) & 0.35 & 0.34 & 0.34 & 0.34 & 0.33 \\
Heat/Fuel Ratio & 1.07 & 1.09 & 1.13 & 1.18 & 1.23 \\
Power/Heat Ratio & 5,242 & 5,201 & 5,096 & 4,987 & 4,843 \\
Net Heat Rate (Btu/kWh) & & & & & \\
\hline Emissions Characteristics & 1,080 & 1,070 & 1,035 & 1,005 & 975 \\
\hline NO (ppm) & 25 & 15 & 5 & 3 & 3 \\
NO (lb/MWh) & 0.8 & 0.5 & 0.2 & 0.1 & 0.1 \\
CO (ppm) & 20 & 20 & 15 & 15 & 15 \\
CO (lb/MWh) & 0.4 & 0.4 & 0.3 & 0.3 & 0.3 \\
CO $($ lb/MWh) & & & \\
\hline
\end{tabular}




\subsection{References}

Energy and Environmental Analysis, Inc., Assessment of Emission Control Technologies for Distributed Resource Options, GRI/EPRI Report, GRI-99/064, 1999.

Energy Nexus Group, Performance and Cost Trajectories of Clean Distributed Generation Technologies, Prepared for The Energy Foundation, May 29, 2002.

HRSG Users Guide, Power, Vol. 146, No. 7, October 2002.

Manufacturers of Emissions Controls Association, Available Technology Options for Short-Term VOC, NOx, CO, PM and Toxic Emission Reductions, November, 1999.

Gas Turbine World - 1999-2000 Handbook, Pequot Publishing, Inc., Fairfield, CT.

Gas Turbine World - 2001-2002 Handbook, Pequot Publishing, Inc., Fairfield, CT.

Onsite Energy Corporation, Small Gas Turbines for Distributed Generation Markets, GTI/EPRI Report, GTI-00/0219, December 2000.

Rivera, S., Resource Catalysts, Powers, W., Powers Engineering, Gas Turbine Environmental Siting Considerations, EPRI report - 1000651, December 2000.

Schimmoller, B, "Gas Turbines Bask in the Bubble," Power Engineering, Vol. 103, No. 5, May, 1999.

"Unique Combined-Cycle Design for Cyclical Demand Profiles," Power Engineering, Vol. 106, No. 1, January 2002.

U.S. Department of Energy, Distributed Gas Turbine of the Future Workshop Proceedings, Washington, D.C., June 2003.

Gas Turbine and Component Manufacturers

Alstom, www.alstom.com

Catalytica Combustions Systems, www.catalytica-inc.com

Dresser Rand Company, www.dresser-rand.com

General Electric, www.gepower.com

Goal Line Environmental Technologies, www.sconox.com 
Kawasaki Turbines, www.kawasaki.com

Pratt and Whitney, www.pratt-whitney.com

Rolls Royce - Allison, www.rolls-royce.com

Solar Turbines, Inc., www.solarturbines.com

Siemens-Westinghouse, www.pg.siemens.com

Vericor Power Systems, www.vericor.com 


\section{Microturbine Systems}

\subsection{Overview}

Microturbines are small gas turbines that burn gaseous and liquid fuels to create a high-energy gas stream that turns an electrical generator. Today's microturbine technology is the result of development work in small stationary and automotive gas turbines, auxiliary power equipment, and turbochargers - much of which was pursued by the automotive industry beginning in the 1950s. Microturbines entered field-testing around 1997 and began initial commercial service in 1999-2000.

The size range for microturbines (either commercially available or in development) is from 30 to 400 kilowatts $(\mathrm{kW})$, while conventional gas turbine sizes range from $500 \mathrm{~kW}$ to more than 300 megawatts (MW). Microturbines, like larger gas turbines, can be used in power-only generation or in combined heat and power (CHP) systems and can operate on a wide variety of fuels.

Microturbines generally have marginally lower electrical efficiencies than similarly sized reciprocating engine generators. However, because of their design simplicity and relatively few moving parts, microturbines have the potential for simpler installation, higher reliability, reduced noise and vibration, lower maintenance requirements, and possibly lower capital costs compared to reciprocating engines. Achievement of this potential will depend on early commercial success and rapidly growing sales to support large-volume production, an expanded sales and service infrastructure and continued technology development.

Microturbines also have significantly lower emissions signatures (i.e., lower $\mathrm{NO}_{\mathrm{x}}$ and $\mathrm{CO}$ emissions) than reciprocating engines. Microturbine emissions can be up to eight times lower than diesel generators, ${ }^{1}$ and currently available microturbine products produce less than $50 \%$ of the $\mathrm{NO}_{\mathrm{x}}$ emissions of a state-of-the-art natural gas lean-burn engine. In resource recovery applications, microturbines can burn waste gases that would otherwise be flared directly into the atmosphere.

\subsection{Applications}

Microturbines are well suited for a variety of distributed generation applications due to their flexibility in connection methods, ability to be stacked in parallel to serve larger loads, ability to provide reliable power, and low-emissions profile. Potential applications for microturbines in power-only configuration include peak shaving, certain baseload applications such as premium and remote power, and grid support. Combined heat and power (CHP) applications utilize the heat contained in the exhaust gases from the microturbine to produce domestic hot water, to heat building space, to drive absorption cooling or desiccant dehumidification equipment, or to supply other thermal energy needs in a building or industrial process. Target customers for applications are in light industrial facilities; and financial services, data processing, telecommunications, health-care, lodging, retail, offices, schools, and other commercial or institutional buildings.

\footnotetext{
1 "Grid Power Solutions: The North American Market for Distributed Generation and Ride Through Technologies." Venture Development Corporation, June 2001, p. 243. 
Many of the early-entry microturbines are currently operating in oil and gas production fields, wellheads, coal mines, and landfill operations, where byproduct gases serve as ready and essentially free fuel that would otherwise be flared or allowed to escape to the atmosphere.

\subsection{Power-Only}

\section{Peaking}

In certain areas, customers and utilities are using on-site power generation to reduce the cost of peak-load power. Peak shaving is applicable to customers with poor load factor and/or high electricity demand charges. Typically, peak shaving does not involve heat recovery, although thermal recovery may be cost effective if the peak period is more than 2,000 hours/year. Generally, low equipment cost and high reliability are the primary requirements for peaking applications. Emissions may be an issue if the annual number of operating hours is high or the operating facility is located in a nonattainment area. Where peak shaving can be combined with another function, such as standby or emergency power, the economics are considerably enhanced.

There are three possible peak-shaving strategies. First, customers can independently optimize the use of purchased versus generated power under applicable rate structures. Under this strategy, on-site generation would operate during the utility-defined, more costly peak periods. This creates an operating strategy that can vary, depending on the tariff, from 900 hours/year to as many as 3,500 hours/year. Second, some utilities offer coordinated peak-shaving programs in which the utility offers payments to the customer for very limited hours of use upon request from the utility. These programs typically require that the system operate between 50 to 400 hours/year. Third, for customers who purchase power competitively, there is an opportunity to produce their own power more cheaply during the hours of high peak pricing or to select more competitive, interruptible power-supply contracts. In the competitive market strategy, the hours of operation probably would be closer to the reduced hours of the coordinated utility program than the independent peak shaving of a published tariff. The optimal technology configuration and the need to integrate the value of standby power with the value of peak shaving differ markedly among these operating strategies.

In general, current market-entry microturbines are too costly to provide economic peaking power in most regions of the United States. However, peaking may develop into a significant microturbine application if the potential for lower capital costs and increased efficiencies can be achieved as microturbine markets develop and the technology matures.

\section{Premium Power}

Consumers who require higher levels of reliability or power quality, and are willing to pay a premium for it, often find some form of distributed generation to be advantageous. These consumers are typically less concerned about the initial prices of power-generating equipment than other types of consumers. In the premium power market, the current high prices of microturbines may be justified, based on their potential advantages in terms of low emissions, reduced vibration, ease of installation, potential for high availability and reliability, and good 
power quality. As is often the case in premium power applications, noise, vibration, and emissions can be significant concerns.

\section{Remote Power}

In locations where power from the local grid is unavailable or extremely expensive to install, microturbines can be a competitive option. Electric service points tend to be far apart in remote locations. Thus, connection to the local grid by installing an electrical distribution system from the grid to small users can be very costly. The allowable initial costs of connecting to the grid are often higher than installation of a distributed generation system. As with premium power, remote power applications also are generally base-load operations. As a result, on a long-term basis, emissions and fuel-use efficiency become more significant criteria in much of the remote power market. However, remote power applications also include oil and gas production fields, wellheads, coal mines and landfills, where byproduct gases serve as readily available, low-cost fuel. These locations are often far from the grid; and, even when served by the grid, may experience costly downtime when electric service is lost due to weather, fire, or animals. The fuel flexibility of microturbines becomes a significant asset in these facilities, as evidenced by the early market success of microturbines in these applications.

\section{Grid Support}

A growing number of utilities employ diesel or natural gas engines at substations to provide incremental peaking capacity and grid support. Such installations can defer the need for T\&D system upgrades, can provide temporary peaking capacity within constrained areas, or be used for system power factor correction and voltage support, thereby reducing costs for both customers and the utility system. Microturbines are suitable for such service as well, particularly if multiple units are used to increase available capacity and site reliability.

\subsection{Combined Heat and Power}

Combined heat and power (CHP) systems combine on-site power generation with the use of byproduct heat. The economics of microturbine power generation are enhanced by continuous baseload operation and the effective use of the thermal energy contained in the exhaust gas. Heat can generally be recovered in the form of hot water or low-pressure steam $(<30 \mathrm{psig})$, or the hot exhaust also can be used directly for applications such as process heating or drying (e.g. grain drying, brick drying or greenhouses). The exhaust heat can be used to drive thermally activated equipment, such as absorption chillers for cooling or desiccant wheel regeneration for dehumidification.

Commercial/institutional buildings and light industrial facilities whose electrical loads and space heating, hot water, or other thermal needs occur at the same time are usually best suited for microturbine CHP applications. The simplest thermal requirement to supply is hot water. Primary applications for microturbine CHP in the commercial/institutional sectors are those building types with relatively high and coincident electric and hot water demand such as colleges and universities, hospitals and nursing homes, and lodging buildings. Office buildings and certain warehousing and mercantile/service applications also may be economic applications for 
microturbine CHP systems because noise and emissions are often siting and permitting issues. Primary CHP applications in the light industrial market include food processing, chemicals, and plastics-forming plants with hot water or low-pressure steam demands. Heat-activated cooling, refrigeration, and desiccants technologies now being developed for use with engine-driven systems also will broaden microturbine CHP applications by increasing the thermal energy loads in certain building types such as restaurants, supermarkets, offices, and refrigerated warehouses.

\subsection{Technology Description}

\subsection{Basic Process and Components}

Microturbines are very small gas turbines (30 to $400 \mathrm{~kW}$ ), which usually have an internal heatrecovery heat exchanger - called a recuperator - to improve electrical efficiency. In typical microturbines, the inlet air is compressed in a radial (centrifugal) compressor, and then preheated in the recuperator using heat from the turbine exhaust. Heated air from the recuperator is mixed with fuel in the combustor and burned. The hot combustion gas is then expanded in one or more turbine sections, producing rotating mechanical power to drive the compressor and the electric generator.

\subsection{Types of Microturbines}

In single-shaft models, a single expansion turbine turns both the compressor and the generator. Two-shaft models use one turbine to drive the compressor and a second turbine to drive the generator, with exhaust from the compressor turbine powering the generator turbine. The power turbine's exhaust is then used in the recuperator to preheat the air from the compressor.

Single-shaft models are designed to operate at high speeds - some in excess of 100,000 revolutions per minute (rpm) - and generate electrical power as high-frequency alternating current (AC). The generator output is rectified to direct current (DC) and then inverted to 60 hertz $(\mathrm{Hz}) \mathrm{AC}$ for commercial use in the United States. Two-shaft microbturbines have a turbine-driven compressor on one shaft and a separate power turbine on a second shaft to power the generator. With the expansion pressure ratio split between two turbines, the power turbine on a two-shaft machine can be designed to run at lower speed with high efficiency. The power turbine is connected to a conventional $60 \mathrm{~Hz} \mathrm{AC}$ generator through a low-cost, single-stage gearbox. Some manufacturers offer units producing $50 \mathrm{~Hz}$ AC for use in countries where $50 \mathrm{~Hz}$ is standard, such as in Europe and parts of Asia.

\section{Thermodynamic Cycle}

Microturbines and larger gas turbines operate on the same thermodynamic cycle, known as the Brayton cycle. In this cycle, atmospheric air is compressed, heated at constant pressure, and then expanded, with the excess power produced by the expander (also called the turbine) consumed by the compressor used to generate electricity. The power produced by an expansion turbine and consumed by a compressor is proportional to the absolute temperature of the gas passing through 
those devices. Higher expander inlet temperature and pressure ratios result in higher efficiency and specific power ${ }^{2}$. Consequently, for good power and efficiency, it is advantageous to operate the expansion turbine at the highest practical inlet temperature consistent with economic turbine blade materials and to operate the compressor with inlet air at the lowest temperature possible. The general trend in gas turbine advancement has been toward a combination of higher temperatures and pressures. However, microturbine inlet temperatures are generally limited to $1750^{\circ} \mathrm{F}$ or below to enable the use of relatively inexpensive materials for the turbine wheel and recuperator. For recuperated turbines, the optimum pressure ratio for best efficiency is usually less than 4:1.

\section{Turbo-Compressor Package}

The basic components of a microturbine are the compressor, turbine, generator, and recuperator (see Figure 1). The heart of the microturbine is the compressor-turbine package, which is most commonly mounted on a single shaft along with the electric generator. The single shaft is supported by two (or more) high-speed bearings. Because single-shaft turbines have only one moving part, they have the potential for low maintenance and high reliability. There are also two-shaft versions of the microturbine, in which the turbine on the first shaft only drives the compressor while a second power turbine on a second shaft drives a gearbox and conventional electrical generator producing $60 \mathrm{~Hz}$ power. The two-shaft design has more moving parts but does not require power electronics to convert high frequency AC power output to usable $60 \mathrm{~Hz}$ power.

Figure 1. Microturbine-Based CHP System (Single-Shaft Design)

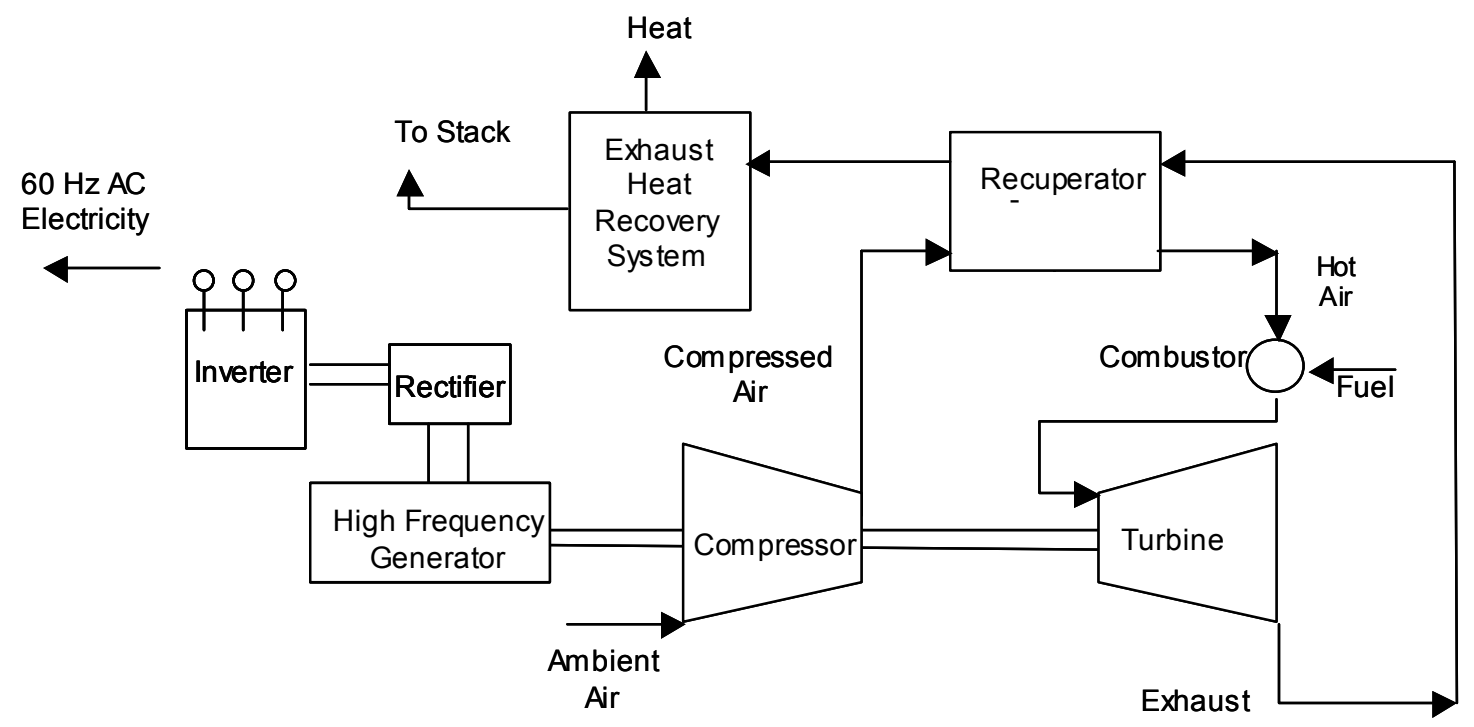

\footnotetext{
${ }^{2}$ Higher-pressure ratios increase efficiency and specific power until an optimum pressure ratio is achieved, beyond which efficiency and specific power decrease. The optimum pressure ratio is considerably lower when a recuperator is used.
} 
Moderate- to large-size gas turbines use multistage axial flow compressors and turbines, in which the gas flows parallel to the axis of the shaft and then is compressed and expanded in multiple stages. Most current microturbines are based on single-stage radial flow compressors and either single- or two-stage turbines. Radial flow turbomachinery can handle the very small volumetric flows of air and combustion products with higher component efficiency and with the simpler construction than axial flow components. ${ }^{3}$ While large-size axial flow turbines and compressors are typically more efficient than radial flow components, in the size range of microturbines -0.5 to $5 \mathrm{lbs} / \mathrm{second}$ of air/gas flow - radial flow components offer lower surface and end wall losses and provide higher efficiency. Radial flow components generally cost less to manufacture.

In microturbines, the turbocompressor shaft turns at high speed, about $96,000 \mathrm{rpm}$ in $30 \mathrm{~kW}$ machines and about $70,000 \mathrm{rpm}$ in $100 \mathrm{~kW}$ machines. While rotational speed generally increases as physical size decreases, there is no single rotational speed-power size rule. The specific turbine and compressor design characteristics for a given power output influence the physical size of components and consequently rotational speed. For a specific aerodynamic design, as the power rating and the compressor and turbine diameters decrease, the shaft speed required to maintain turbine operability increases, hence the very high shaft speed of the very small microturbines.

Radial flow turbine-driven compressors are quite similar in terms of design and volumetric flow to turbochargers used in automobiles, trucks, and other small reciprocating engines.

Superchargers and turbochargers have been used for almost 80 years to increase the power of reciprocating engines by providing compressed inlet air to the engine. Today's worldwide market for small automobile and truck turbochargers is around two million units per year, and is characterized by relatively low prices to the vehicle engine original equipment manufacturers. Very small gas turbines, of the size and power rating of microturbines, have been used extensively in auxiliary power systems and auxiliary power units on airplanes. The decades of experience with these applications provide the basis for the engineering and manufacturing technology of emerging microturbine components.

\section{Recuperators}

Recuperators are air to gas heat exchangers that use the hot turbine exhaust gas (typically around $1,200^{\circ} \mathrm{F}$ ) to preheat the compressed air (typically around $300-400^{\circ} \mathrm{F}$ ) before the compressed air goes into the combustor, thereby reducing the fuel needed to heat the compressed air to the design turbine inlet temperature. Microturbines require a recuperator to achieve the efficiency levels needed to be competitive in continuous duty service. Depending on microturbine operating parameters, recuperators can increase machine efficiency by as much as a factor of two. However, since there is increased pressure drop in both the compressed air and turbine exhaust sides of the recuperator, power output typically declines $10 \%$ to $15 \%$ on a recuperated turbine. Recuperators also lower the temperature of the microturbine exhaust, an important consideration in CHP applications.

\footnotetext{
${ }^{3}$ With axial flow turbomachinery, blade height would be too small to be practical or efficient. 


\section{Bearings}

Microturbines shafts may be supported on either oil-lubricated or air bearings. Oil-lubricated bearings are mechanical bearings and come in three main forms - high-speed metal ball or roller, floating sleeve, and ceramic surface. The latter typically offers the most attractive benefits in terms of life, operating temperature, and lubricant flow. While oil-lubricated bearings are a wellestablished technology, they require an oil pump, oil-filtering system, and oil cooling, which add to microturbine cost and maintenance. Also, the exhaust from machines featuring oil-lubricated bearings may not be usable for direct process heating in cogeneration configurations due to the potential for contamination of the exhaust. Still, since the oil never comes in direct contact with hot combustion products, as is the case in small reciprocating engines, the expected relatively low oil contamination and replacement requirements of such a lubrication system are more typical of ship propulsion diesel systems (which have separate bearings and cylinder lubrication systems) and automotive transmissions than of automotive engine lubrication.

Air bearings have been in service on airplane auxiliary power systems and cabin-cooling systems for many years. They allow the high-speed turbine to be aerodynamically supported on a thin layer of air, so friction is low. No oil, oil pump, or cooling system is required. Air bearings offer simplicity of operation without the cost, reliability concerns, maintenance requirements, or power drain of an oil supply and filtering system. Concern does exist for the reliability of air bearings under numerous and repeated starts due to metal-on-metal friction during start-up and shutdown. Reliability depends to a large extent on individual manufacturers' quality control methodology and on design engineering - and will only be proven after significant experience with substantial numbers of units with long operating times and many on/off cycles. It should be noted that field experience with microturbines is growing rapidly, and one manufacturer has successfully demonstrated more than 10,000 start-load-stop cycles on numerous commercial service microturbines equipped with air bearings.

\section{Generator}

The microturbine produces electrical power either via a high-speed generator directly driven by the single turbo-compressor shaft or with a separate power turbine driving a gearbox and conventional 3,600 rpm generator. The high-speed generator of the single-shaft design employs a permanent magnet (typically Samarium-Cobalt) alternator, and requires that the high frequency AC output (about $1,600 \mathrm{~Hz}$ for a $30 \mathrm{~kW}$ machine) be converted to $60 \mathrm{~Hz}$ for general use. This power conditioning involves rectifying the high frequency $\mathrm{AC}$ to $\mathrm{DC}$, and then inverting the $\mathrm{DC}$ to $60 \mathrm{~Hz} \mathrm{AC}$. Frequency conversion comes with a small efficiency penalty (on the order of 5\%). To start the single-shaft design, the generator serves as a motor turning the turbo-compressor shaft until sufficient speed (rpm) is reached to allow the compressor to supply enough air for self-sustaining combustion. If the system is operating independent of the grid (black-start capability), a power storage unit (typically a battery UPS) is used to power the generator for start-up. Two-shaft designs use a separate starting system. 


\section{Power Electronics}

As discussed, single-shaft microturbines feature digital power controllers to convert the highfrequency AC power produced by the generator into commercially usable electricity. The high frequency $\mathrm{AC}$ is rectified to $\mathrm{DC}$, inverted back to 60 or $50 \mathrm{~Hz} \mathrm{AC}$, and then filtered to reduce harmonic distortion. Power electronics are a critical component in the single-shaft microturbine design and represent significant design challenges, specifically in matching turbine output to the required load. Power electronics are generally designed to handle seven times the nominal voltage to allow for transients and voltage spikes. Most microturbine power electronics are designed for generating three-phase electricity.

Electronic components control all of the engine/generator operating and start-up functions. Microturbines are generally equipped with controls that allow the unit to be operated either in parallel with or independent of the grid, and they incorporate many of the grid- and systemprotection features required for interconnect. The controls usually also allow for remote monitoring and operation.

\section{Fuel Gas Compressors}

Microturbines require gaseous fuel to be supplied in the 64 to 90 psig range (or above). Most local gas-distribution systems operate well below this range. Rotary vane, scroll, and screw compressors have been used to boost gas pressure at the site to the pressure needed by the microturbine.

\section{CHP Operation}

In CHP operation, a second heat-recovery heat exchanger - the exhaust gas heat exchanger - can be used to transfer remaining energy from the microturbine exhaust to a hot water system. Exhaust heat can be used for a number of different applications, including process or space heating, heating potable water, driving absorption chillers, or regenerating desiccant dehumidification equipment. Some microturbine-based CHP applications do not use recuperators, and some have the ability to bypass their recuperator to adjust their thermal to electric ratio. The temperature of the exhaust from these microturbines is much higher (up to $1200^{\circ} \mathrm{F}$ ) and thus more heat is available for recovery. A microturbine-based CHP system was previously illustrated in Figure 1.

\subsection{Design Characteristics}

Thermal output: $\quad$ Microturbines produce waste heat in the exhaust gas at temperatures in the $400^{\circ} \mathrm{F}$ to $650^{\circ} \mathrm{F}$ range, suitable for supplying a variety of building and light industrial thermal needs. 
Fuel flexibility:

Reliability and life:

Size range:

Emissions:

Modularity:

Part-load operation:
Microturbines can operate using a number of different fuels: natural gas, sour gases (high sulfur, low Btu content), landfill gas, digester gas, and liquid fuels (gasoline, kerosene, and diesel fuel/heating oil).

Design life is estimated to be in the 40,000 - to 80,000 -hour range. While units have demonstrated reliability, they have not been in commercial service long enough to provide definitive life data.

Microturbines available or under development are sized from 30 to $400 \mathrm{~kW}$.

Sophisticated combustion schemes, relatively low turbine inlet temperatures, and low (lean) fuel-to-air ratios result in $\mathrm{NO}_{\mathrm{x}}$ emissions of less than 10 parts per million (ppm) and inherently low $\mathrm{CO}$ and unburned hydrocarbon emissions, especially when running on natural gas.

Units may be connected in parallel to serve larger loads and provide power reliability.

Because microturbines reduce power output by reducing mass flow and combustion temperature, efficiency at part load is below that of full-power efficiency.

\subsection{Cost and Performance Characteristics}

This section describes the cost and performance of microturbine systems for two primary applications. The first is for systems designed to produce power only. Systems configured for this purpose could be used in a variety of the applications described in Section 2, including premium power, peaking, and grid support. The second configuration discussed in this section is combined heat and power (CHP), where additional equipment is added to the basic microturbine to allow recovery and subsequent use of exhaust heat in industrial processes or commercial buildings. CHP applications are the primary market for early-entry microturbine systems, as utilization of the waste heat can significantly enhance project economics.

\subsection{System Performance}

The thermal efficiency of the Brayton cycle is a function of pressure ratio, ambient air temperature, turbine inlet air temperature, the efficiency of the compressor and turbine elements, and any performance enhancements such as heat recuperation. The addition of the recuperator makes microturbines more complex than conventional simple-cycle gas turbines. The recuperator reduces fuel consumption (thereby substantially increasing efficiency) but also introduces additional internal pressure losses that moderately lower efficiency and power. Because the recuperator has four connections - to the compressor discharge, the expansion turbine discharge, the combustor inlet, and the system exhaust - it becomes a challenge to 
microturbine product designers to integrate recuperation in a manner that minimizes pressure loss, keeps manufacturing cost low, and entails the least compromise of system reliability when operated and thermally cycled for extended periods. Each manufacturer's models have evolved in unique ways to meet these challenges.

Table 1 provides cost and performance characteristics for typical emerging microturbine CHP systems. The range of 30 to $100 \mathrm{~kW}$ represents what is currently or soon to be commercially available. Microturbine package performance characteristics are shown in the top portion of the table and are applicable to both power-only and CHP applications. Total installed-cost estimates are provided for both applications. Heat rates and efficiencies shown were taken from manufacturers' specifications and industry publications. Electrical efficiencies are net of the parasitic and conversion losses as indicated in a footnote to the table. Available thermal energy is calculated based on manufacturer specifications on turbine exhaust flows and temperatures. CHP thermal recovery estimates are based on producing hot water for process or space-heating applications and a heat recovery unit exhaust temperature of $220^{\circ} \mathrm{F}$. Total $\mathrm{CHP}$ efficiency is defined as the sum of the net electricity generated plus the useful thermal energy (hot water) produced for thermal needs, as a fraction of total fuel input energy.

Microturbine systems can have different electrical and CHP efficiencies based on the specific design parameters selected by the manufacturer. Each microturbine manufacturer represented in Table 1 uses a unique recuperator configuration, and each has made individual tradeoffs between cost and performance. The cost and performance tradeoffs involve the extent to which the recuperator effectiveness increases turbine efficiency, the extent to which the recuperator pressure drop decreases power, and the chosen turbine pressure ratio.

As shown, microturbines typically require 50 to 90 psig fuel supply pressure. Because current microturbines have pressure ratios between 3 and 4 to maximize efficiency with use of a recuperator at modest turbine inlet temperature, the required supply pressure for microturbines is much less than for industrial-size gas turbines, which normally have pressure ratios of 7 to 35 . Local distribution system gas pressures usually range from 30 to 130 psig in feeder lines and from 1 to 50 psig in final distribution lines. Most U.S. businesses that would use 30, 70, or 100 $\mathrm{kW}$ microturbines receive gas at about 12 to 24 inches of water pressure ( 0.5 to $1.0 \mathrm{psig})$. Most building codes prohibit piping natural gas into buildings at more than $2 \mathrm{psig}$. Thus, microturbines in most commercial locations require a fuel gas booster compressor (GBC) to ensure that fuel pressure is adequate for the gas turbine flow-control and combustion systems. 
Table 1. Microturbine Systems - Typical Performance Parameters (2003)

\begin{tabular}{|c|c|c|c|c|}
\hline Cost and Performance Characteristics ${ }^{4}$ & System 1 & System 2 & System 3 & System 4 \\
\hline Nominal Electricity Capacity (kW) & $30 \mathrm{~kW}$ & $70 \mathrm{~kW}$ & $80 \mathrm{~kW}$ & $100 \mathrm{~kW}$ \\
\hline \multicolumn{5}{|l|}{ Microturbine Characteristics } \\
\hline Net Electrical Capacity $(\mathrm{kW})^{5}$ & 28 & 67 & 76 & 100 \\
\hline Electrical Efficiency (\%), LHV & 25.1 & 28.0 & 26.9 & 28.9 \\
\hline Electric Heat Rate $(\mathrm{Btu} / \mathrm{kWh}), \mathrm{HHV}^{6}$ & 15,071 & 13,544 & 14,103 & 13,127 \\
\hline Electrical Efficiency (\%), $\mathrm{HHV}^{7}$ & 22.6 & 25.2 & 24.2 & 26.0 \\
\hline Fuel Input (MMBtu/hr) & 0.423 & 0.91 & 1.09 & 1.31 \\
\hline Installed Cost - Power Only $(2003 \$ / \mathrm{kW})$ & 2,263 & 1,708 & 1,713 & 1,576 \\
\hline Installed Cost - CHP $(2003 \$ / \mathrm{kW})^{8}$ & 2,636 & 1,926 & 1,932 & 1,769 \\
\hline O\&M Costs $(2003 \$ / \mathrm{kWh})$ & 0.02 & 0.015 & 0.013 & 0.015 \\
\hline Required Fuel Gas Pressure (psig) ${ }^{9}$ & 55 & 70 & 85 & 90 \\
\hline Required Fuel Gas Pressure w/GBC (psig) ${ }^{10}$ & $0.2-15$ & $0.2-15$ & $0.2-15$ & $0.3-15$ \\
\hline \multicolumn{5}{|l|}{ CHP Characteristics } \\
\hline Exhaust Flow (lbs/sec) & 0.68 & 1.60 & 1.67 & 1.76 \\
\hline Turbine Exhaust Temperature $\left({ }^{\circ} \mathrm{F}\right)$ & 530 & 450 & 500 & 520 \\
\hline Heat Exchanger Exhaust Temperature $\left({ }^{\circ} \mathrm{F}\right)^{11}$ & 220 & 220 & 220 & 220 \\
\hline Heat Output (MMBtu/hr) & 0.186 & 0.325 & 0.412 & 0.466 \\
\hline Heat Output (kW equivalent) & 54 & 95 & 121 & 136 \\
\hline Total CHP Efficiency (\%), HHV ${ }^{12}$ & 67 & 61 & 63 & 62 \\
\hline Heat/Fuel Ratio ${ }^{13}$ & 0.44 & 0.36 & 0.38 & 0.35 \\
\hline Power/Heat Ratio ${ }^{14}$ & 0.52 & 0.70 & 0.63 & 0.73 \\
\hline Net Heat Rate $(\mathrm{Btu} / \mathrm{kWh})^{15}$ & 6,795 & 7,485 & 7,320 & 7,300 \\
\hline
\end{tabular}

Source: EEA estimates of characteristics are representative of "typical" commercially available or soon-to-beavailable microturbine systems.

\footnotetext{
${ }^{4}$ Table data are based on: Capstone Model 330 - $30 \mathrm{~kW}$; IR Energy Systems 70LM - $70 \mathrm{~kW}$ (two-shaft); Bowman TG80 - $80 \mathrm{~kW}$; Turbec T100 - $100 \mathrm{~kW}$. Performance characteristics are based on ISO standard ambient temperature of 59 degrees $\mathrm{F}$.

${ }^{5}$ Net of parasitic losses from gas booster compressor and conversion losses from power conversion equipment.

${ }^{6}$ All turbine and engine manufacturers quote heat rates in terms of the lower heating value (LHV) of the fuel. On the other hand, the usable energy content of fuels is typically measured on a higher heating value (HHV) basis. In addition, electric utilities measure power plant heat rates in terms of HHV. For natural gas, the average heat content of natural gas is 1,030 Btu/scf on a HHV basis and $930 \mathrm{Btu} / \mathrm{scf}$ on an LHV basis - or about a 10\% difference.

${ }^{7}$ Electrical efficiencies are net of parasitic and conversion losses. Fuel gas compressor needs based on 1 psi inlet supply.

${ }^{8}$ Installed costs based on CHP system producing hot water from exhaust heat recovery. The $70 \mathrm{~kW}, 80 \mathrm{~kW}$, and $100 \mathrm{~kW}$ systems are being offered with integral hot water recovery built into the equipment. The $30 \mathrm{~kW}$ units are currently built as electric (only) generators, and the heat recovery water heater is a separate unit.

${ }^{9}$ Fuel gas pressure required at the combustor. This value determines the GBC requirements at a specific site

${ }^{10}$ Fuel gas pressure required to the gas boost compressor (GBC).

${ }^{11}$ Heat recovery calculated based on hot water production $\left(160\right.$ to $\left.180^{\circ} \mathrm{F}\right)$ and heat-recovery unit exhaust temperature of $220^{\circ} \mathrm{F}$.

${ }^{12}$ Total CHP Efficiency $=($ net electric generated + net heat produced for thermal needs $) /$ total system fuel input.

${ }^{13} \mathrm{Heat} /$ Fuel Ratio = Thermal output (total heat recovered MMBtu/hr)/fuel input $(\mathrm{MMBtu} / \mathrm{hr})$.

${ }^{14}$ Power/Heat Ratio $=$ CHP electrical power output $($ Btu equivalent $) /$ useful heat output $(\mathrm{Btu})$.

${ }^{15}$ Net Heat Rate $=($ total fuel input to the CHP system - fuel normally used to generate the same amount of thermal output as the CHP system output, assuming efficiency of $80 \%) / \mathrm{CHP}$ electric output $(\mathrm{kW})$.
} 
Most microturbine manufacturers offer the equipment package with an optional GBC, if needed, to satisfy the microturbine fuel inlet pressure requirement. The $\mathrm{GBC}$ is included in the package cost of all of the representative systems shown in Table 1. This packaging facilitates the purchase and installation of a microturbine, because the burden of obtaining and installing the booster compressor is no longer placed on the customer. Also, it is believed to result in higher reliability of the booster through standardized design and volume manufacture. Booster compressors can add from $\$ 50$ to $\$ 180$ per $\mathrm{kW}$ to a microturbine power-only and CHP system's total cost. As well as adding to capital cost, booster compressors decrease net power and efficiency, making operating cost slightly higher. Typically, about $5 \%$ of the output of a microturbine is needed to power the fuel gas booster drive. Such power loss results in a penalty on efficiency of about 1.5 percentage points. For installations where the unit is located outdoors, customers might be able to save on cost and operating expense by having the gas utility deliver gas at an adequate pressure that eliminates the need for the fuel gas booster compressor.

\section{Microturbine Design Considerations}

As stated earlier, the addition of a recuperator to a gas turbine opens numerous design parameters to performance-cost tradeoffs. In addition to selecting the pressure ratio for high efficiency and best-business opportunity (high power for low price), the recuperator has two performance parameters - effectiveness and pressure drop - that also have to be selected for the combination of efficiency and cost that creates the optimum conditions for the application. Higher effectiveness recuperation requires greater recuperator surface area, which both increases cost and incurs additional pressure drop. Increased pressure drop reduces the net power produced and consequently increases microturbine cost per $\mathrm{kW}$.

Microturbine performance, in terms of both efficiency and specific power, ${ }^{16}$ is highly sensitive to small variations in component performance and internal losses. This is because the highefficiency recuperated cycle processes a much larger amount of air and combustion products flow per $\mathrm{kW}$ of net mechanical power delivered than is the case for high-pressure ratio nonrecuperated gas turbines. Because the net power output is the small difference between two large values (the compressor and expansion turbine work per unit of mass flow), small losses in compressor or turbine efficiency, internal pressure losses, and recuperator effectiveness have large impacts on net system efficiency and power per unit of mass flow. Additionally, variances in manufacturing tolerances can have greater effect on component efficiencies on smaller turbomachinery such as microturbines.

Estimated recuperated microturbine electrical efficiency is shown in Figure 2 as a function of microturbine compressor ratio, for an ambient air temperature of $59^{\circ} \mathrm{F}$ (ISO standard), and a range of turbine inlet temperatures from $1550^{\circ} \mathrm{F}$ to $1750^{\circ} \mathrm{F}$, corresponding to a range of conservative to optimistic turbine material life behavior. The efficiency shown in Figure 2 is defined on the basis of generator output without parasitic or conversion losses considered. Often this output is at high frequency, so it must be rectified and inverted to provide $60 \mathrm{~Hz}$ AC power. The efficiency loss in such frequency conversion (about 5\%, which would lower efficiency from $30 \%$ to $28.5 \%$ ) is not included in these charts. Figure 2 shows that a broad near-optimum of performance exists in the pressure ratio range of 2.5 to 4.5 .

16 "Specific power" is power produced by the machine per unit of mass flow through the machine. 


\section{Figure 2. Typical Microturbine Efficiency as a Function of Compressor Pressure Ratio and Turbine Inlet Temperature ${ }^{17}$}

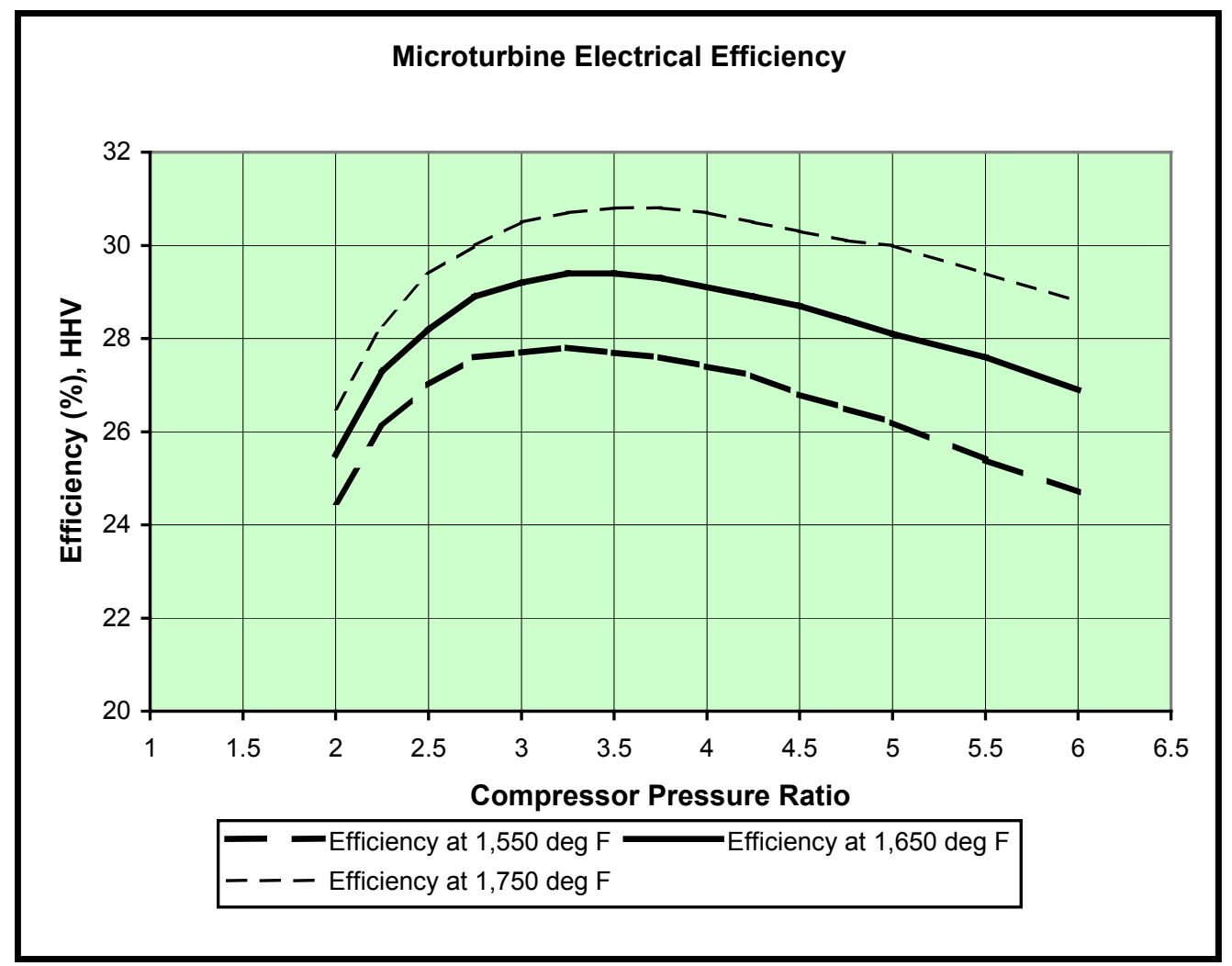

Source: Energy and Environmental Analysis, Inc., estimates

Figure 3 shows microturbine specific power for the same range of firing temperatures and pressure ratios as in Figure 2. Greater specific power can be obtained with higher-pressure ratios. Higher-pressure ratios are developed by higher rotational speeds, but these speeds are limited by the stress that can be tolerated by practical turbine blade materials. These considerations along with manufacturing cost trade-offs limit compressor pressure ratios to $3: 1$ to 4:1 in microturbines currently entering the market.

\footnotetext{
${ }^{17}$ Most of the efficiencies quoted in this report are based on higher heating value (HHV), which includes the heat of condensation of the water vapor in the combustion products. In engineering and scientific literature, the lower heating value (LHV) is often used, which does not include the heat of condensation of the water vapor in the combustion product). Fuel is sold on a HHV basis. The HHV is greater than the LHV by approximately $10 \%$ with natural gas as the fuel (i.e., $50 \% \mathrm{LHV}$ is equivalent to $45 \% \mathrm{HHV}$ ). HHV efficiencies are about $8 \%$ greater for oil (liquid petroleum products) and $5 \%$ greater for coal.
} 
Figure 3. Microturbine Specific Power as a Function of Compressor Pressure Ratio and Turbine Inlet Temperature

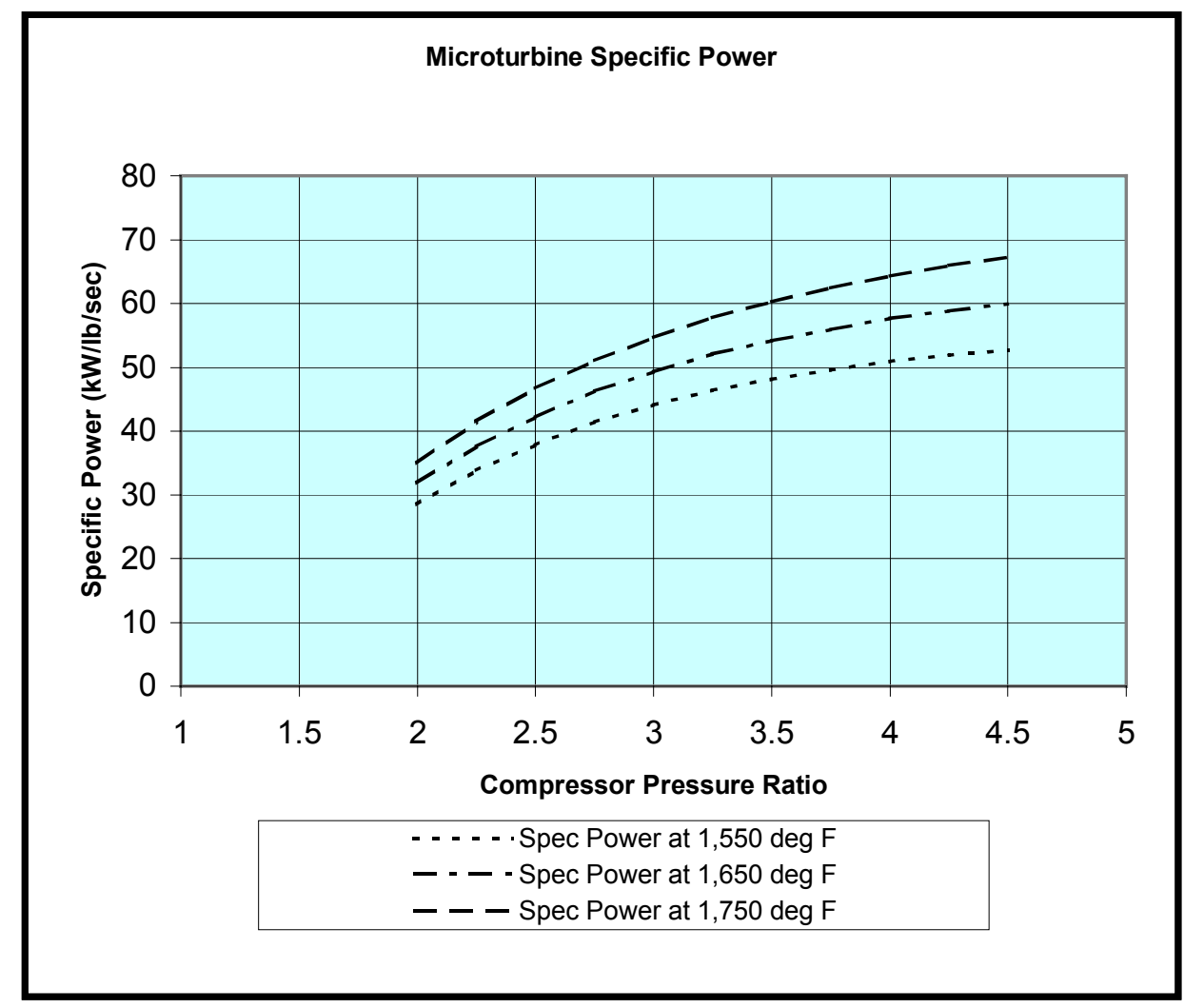

Source: Energy and Environmental Analysis, Inc., estimates

\section{Part-Load Performance}

When less than full power is required from a microturbine, the output is reduced by reducing rotational speed, which reduces temperature rise and pressure ratio through the compressor and temperature drop through the turbine, and by reducing turbine inlet temperature so that the recuperator inlet temperature does not rise. In addition to reducing power, this change in operating conditions also reduces efficiency. The efficiency decrease is minimized by the reduction in mass flow (through speed reduction) at the same time as the turbine inlet temperature is reduced. Figure 4 shows a typical part-load efficiency curve based on a $30 \mathrm{~kW}$ microturbine. 
Figure 4. Microturbine Part-Load Efficiency

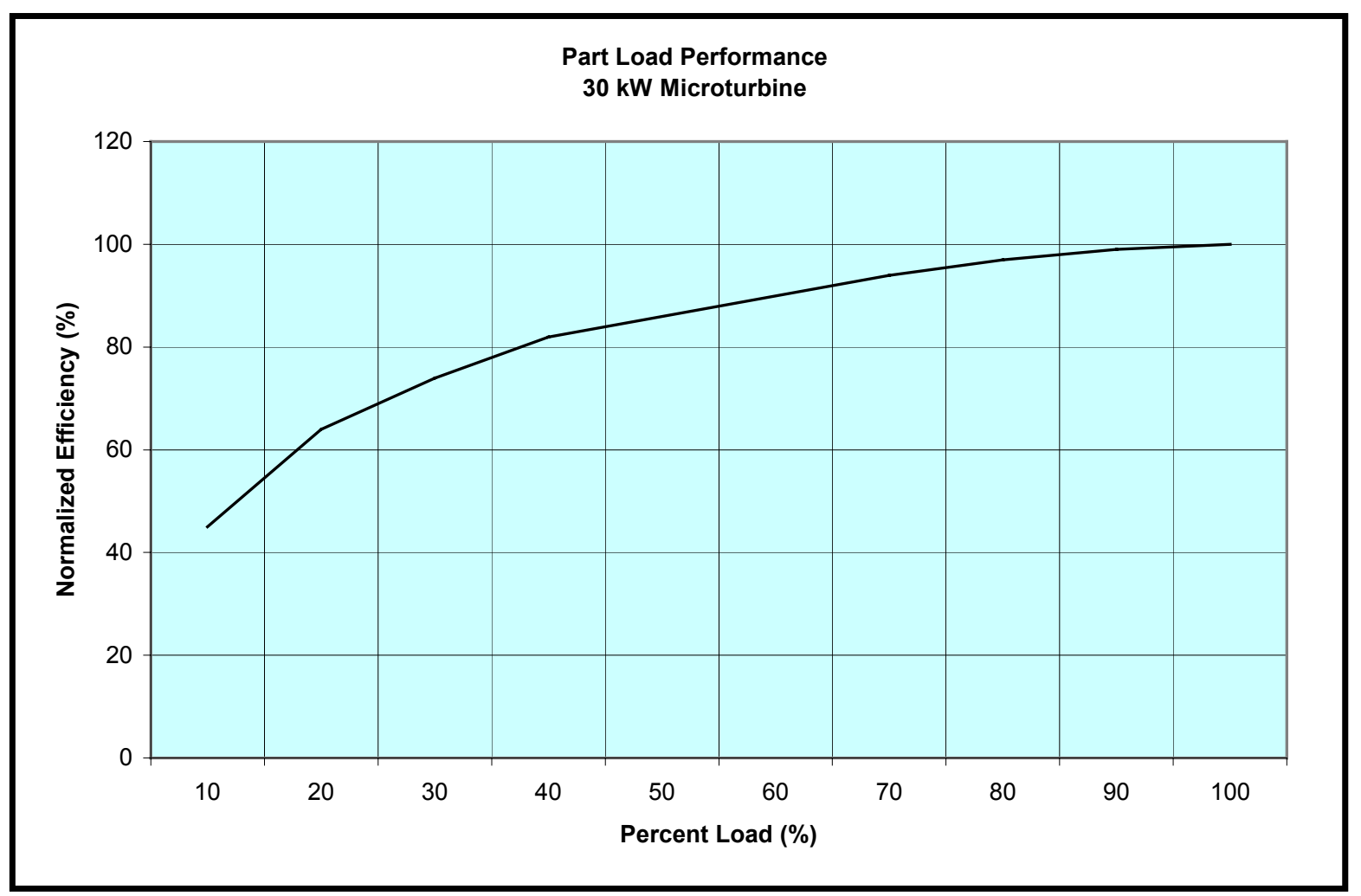

Note: Unit represented is a single-shaft, high-speed alternator system

Source: Energy and Environmental Analysis, Inc., estimates

\section{Effects of Ambient Conditions on Performance}

The ambient conditions at the inlet of the microturbine affect both the power output and efficiency. At inlet air temperatures above $59^{\circ} \mathrm{F}$, both the power and efficiency decrease. The power decreases, due to the decreased air density with increasing temperature and the efficiency decreases because the compressor requires more power to compress higher temperature air. Conversely, the power and efficiency increase when the inlet air temperature is below $59^{\circ} \mathrm{F}$. Figure 5 shows the variation in power and efficiency for a microturbine as a function of ambient temperature relative to the reference International Organization for Standards (ISO) condition of sea level and $59^{\circ} \mathrm{F}$. It should be noted that some manufacturers may place limitations on maximum power output below a certain ambient temperature due to maximum power limitations of the gearbox, generator, or power electronics, and this may modify the shape of the curves shown in Figure 5. 
Figure 5. Ambient Temperature Effects on Microturbine Performance*
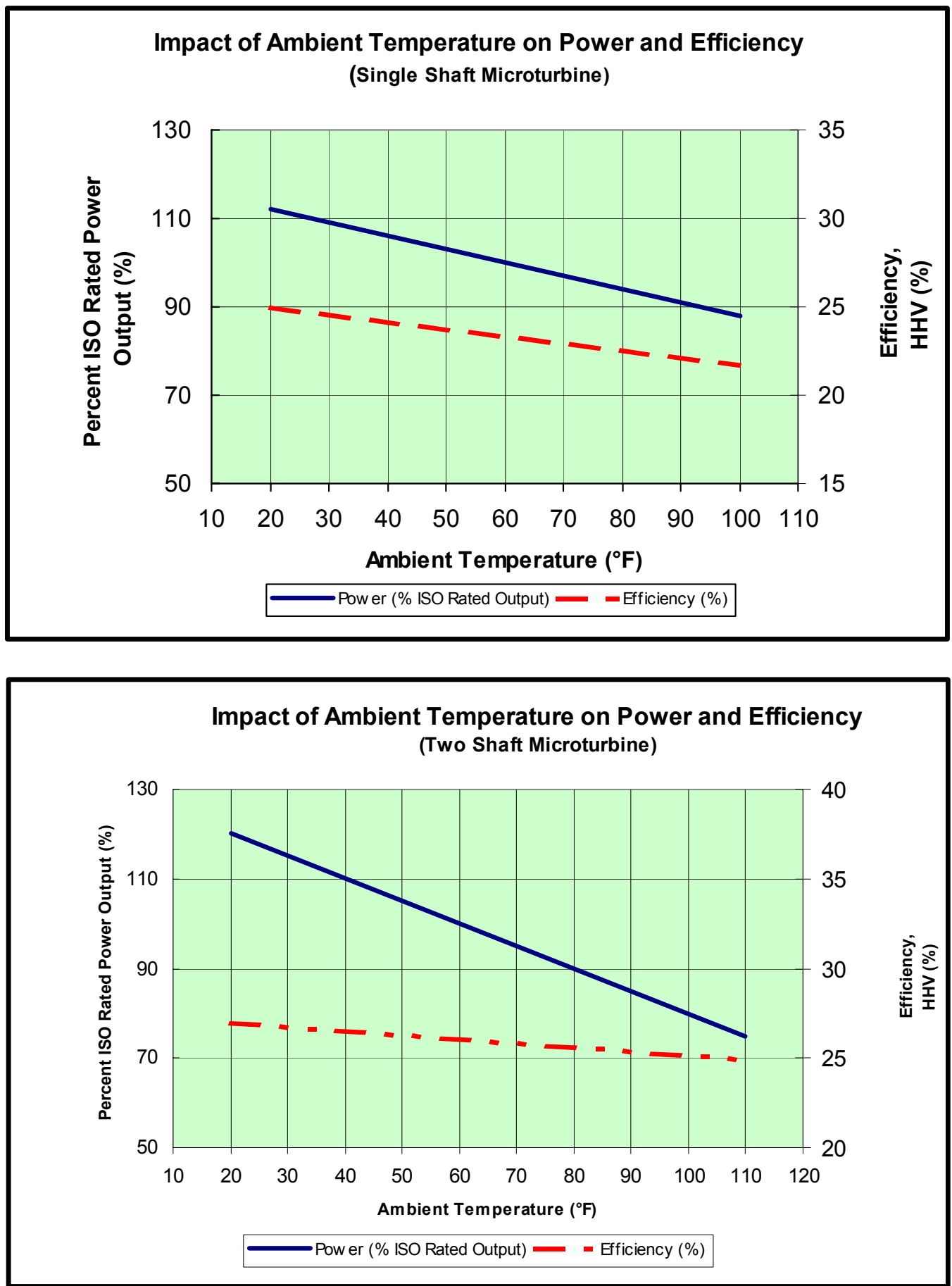

*Note: Power presented as a percent of ISO rated power over range of ambient conditions; efficiency represented as net electrical efficiency over ambient conditions

Source: Energy and Environmental Analysis, Inc., estimates 
The density of air changes with altitude. Density decreases at increasing altitudes, and, consequently, power output decreases. Figure 6 illustrates the derate effect of altitude on microturbine power output. Altitude has relatively little effect on efficiency.

Figure 6. Altitude Effects on Microturbine Power Output

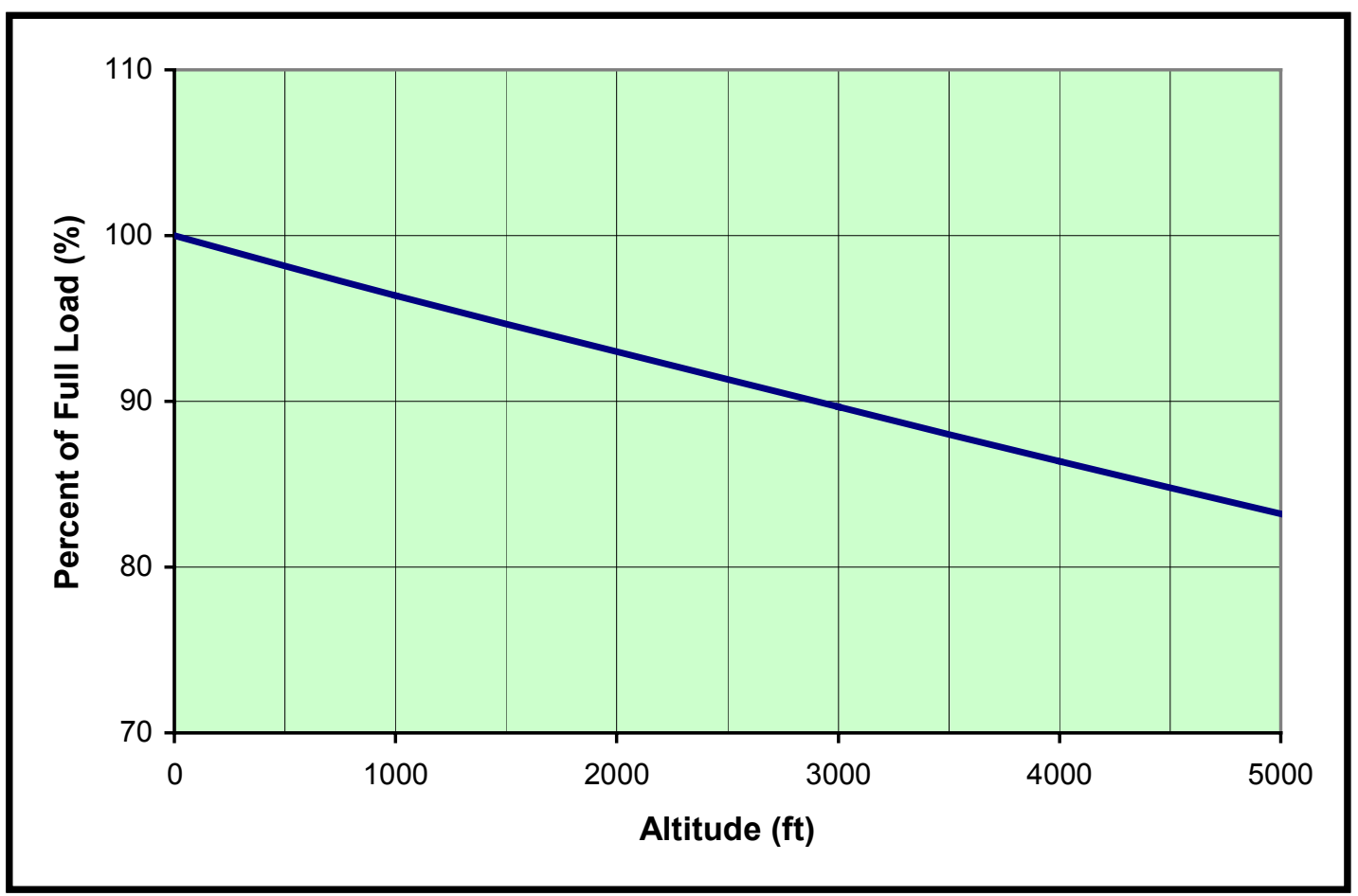

Source: Energy and Environmental Analysis, Inc., estimates

\subsection{Combined Heat and Power Performance}

Use of the thermal energy contained in the exhaust gas improves microturbine system economics. The heat in the exhaust represents close to $70 \%$ of the inlet fuel energy. Exhaust heat can be recovered and used in a variety of ways, the most common being to generate hot water for water heating, space heating, or process uses, or for "driving" thermally activated equipment, such as absorption chillers or desiccant dehumidifiers.

Microturbine CHP system efficiency is a function of the exhaust gas temperatures from the recuperator and from the heat recovery unit. Manufacturers use recuperators of varying effectiveness in an effort to balance microturbine electrical generating efficiency, CHP efficiency, and equipment cost. Since manufacturers have developed substantially different designs for recuperators, their effectiveness varies among manufacturers and systems. Recuperator effectiveness strongly influences the microturbine exhaust temperature. Consequently, the various microturbine CHP systems have different CHP efficiencies and net heat rate chargeable to power. Variations in efficiency and net heat rate chargeable to power are mostly due to the mechanical design and manufacturing cost of the recuperators and their resulting impact on system cost, rather than being a function of system size. 


\subsection{Performance and Efficiency Enhancements}

\section{Recuperators}

Recuperators are included in most microturbine designs to achieve competitive electrical efficiencies. As shown in Figure 7, the inclusion of a high effectiveness $(90 \%)^{18}$ recuperator increases the electric efficiency of a microturbine from about $14 \%$ to about $26 \%$ for a typical turbine depending on component details.

However, incorporation of a recuperator results in pressure losses through the recuperator itself and in the ducting that connects it to other components. The pressure loss essentially reduces the pressure ratio available to the turbine, impacting both power output and system efficiency. Typically these pressure losses result in $10 \%$ to $15 \%$ less power being produced by the microturbine, and a corresponding loss of a few points in efficiency when compared with an ideal recuperator with a zero pressure drop.

While microturbine performance could be enhanced by using recuperators with higher effectiveness and lower pressure drop, such recuperators would be large and expensive. Effective optimization of recuperator design and integration must balance performance and cost. These must be based on the economic factors of the application (the relative values of electric and thermal energy) rather than from the consideration of the recuperator component alone.

Recuperator durability is also a design and economic issue for microturbine developers. Although recuperators previously in use on industrial gas turbines developed leaks attributable to differential thermal expansion accompanying thermal transients, microturbine recuperators have proven quite durable in testing and commercial applications to date. This improvement in durability has resulted from using higher strength alloys and higher-quality welding, along with improved engineering design to avoid the internal differential expansion that causes stresses resulting in cracks and leakage. Such practical improvements can come at an appreciable cost, again impacting the economic attractiveness of the microturbine.

\footnotetext{
${ }^{18}$ Effectiveness is the technical term in the heat-exchanger industry for the ratio of the actual heat transferred to the maximum achievable
} 
Figure 7. Microturbine Efficiency as a Function of Recuperator Effectiveness

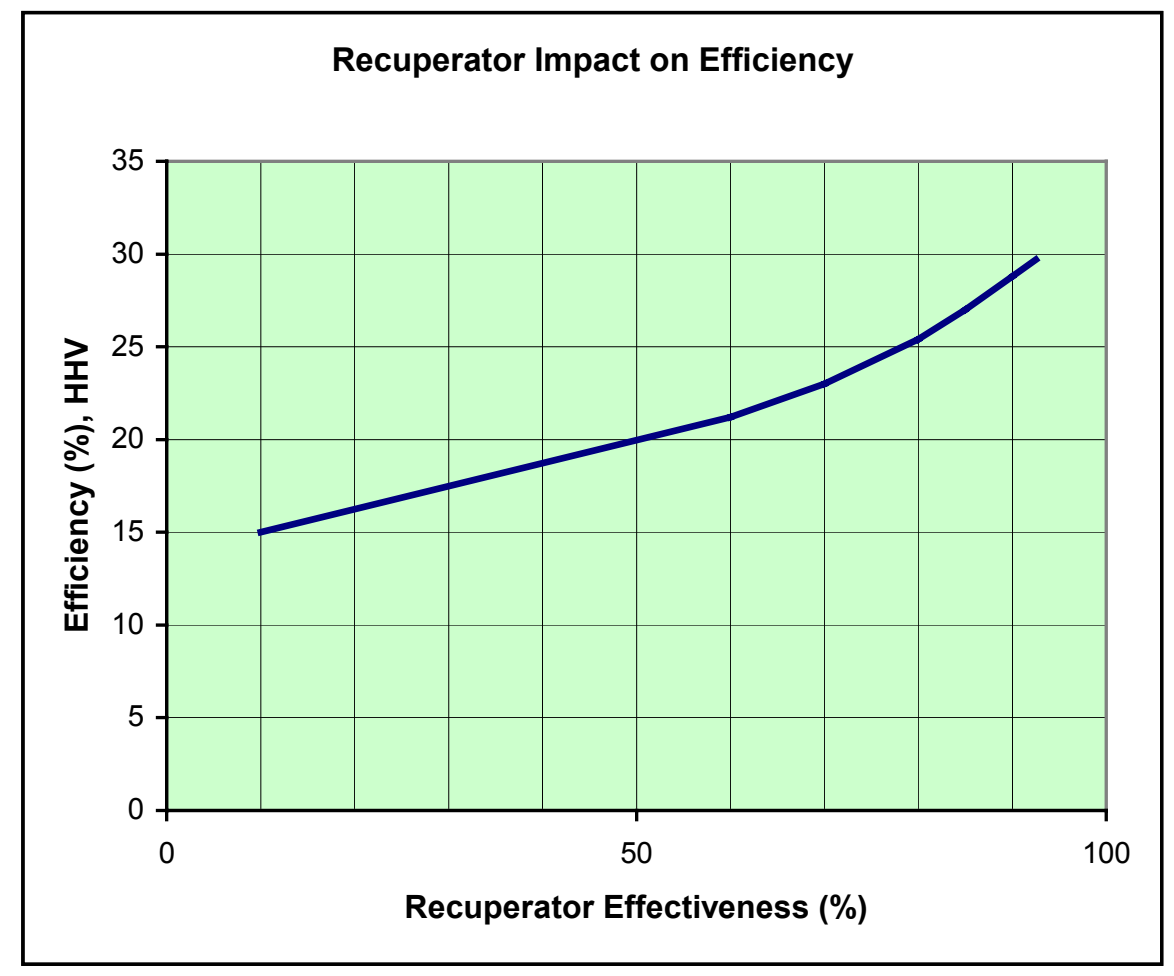

Source: Energy and Environmental Analysis, Inc., estimates, based on turbine pressure ratio of 3.2

\section{Firing (Turbine Inlet) Temperature}

Microturbines are limited to firing temperatures within the capabilities of available gas turbine alloys. This is in contrast to industrial and utility turbines ( 25 to $2,000 \mathrm{lbs} / \mathrm{sec}$ of mass flow), which are usually equipped with internal cooling capability to permit operation with firing temperatures well above those of the service limits of alloys used in gas turbines. Design improvements that enable increased large gas turbine efficiency, via higher firing temperatures, have occurred more through the development and advancement of blade and vane internal cooling technology than through the improvement of the high temperature capabilities of gas turbine alloys. However, the nature of the three-dimensional shape of radial inflow turbines used in microturbines and their small physical size have not yet allowed the development of costeffective manufacturing methods that can produce internal cooling. This is the primary driver for ceramic technology development for future microturbines.

High firing temperature also affects recuperator materials. As the turbine inlet temperature increases, so will turbine outlet temperature, thereby increasing thermal stress and oxidation rates in the recuperators. 


\section{Inlet Air Cooling}

As shown in Figure 5, the decreased power and efficiency of microturbines at high ambient temperatures indicates that microturbine electric-power output is at its lowest when power is typically in greatest demand and most valued (summer peak periods). The use of inlet air cooling can mitigate the decreases in power and efficiency resulting from high ambient air temperatures. While inlet air cooling is not a feature on today's microturbines, cooling techniques now entering the market on large gas turbines can be expected to work their way to progressively smaller equipment sizes - and, at some future date, be used with microturbines if economically viable.

Evaporative cooling, a relatively low capital-cost technique, is the most likely to be applied to microturbines. A fine spray of water is injected directly into the inlet air stream. Evaporation of the water cools the air. Since cooling is limited to the wet bulb air temperature, evaporative cooling is most effective when the wet bulb temperature is appreciably below the dry bulb (ordinary) temperature. In most locales with high daytime dry bulb temperatures, the wet bulb temperature is often $20^{\circ} \mathrm{F}$ lower. This affords an opportunity for substantial evaporative cooling and increased microturbine output. However, evaporative cooling can consume large quantities of high-quality water, making it a difficult and costly application in arid climates.

Refrigeration cooling in microturbines is also technically feasible. In refrigeration cooling, a compression-driven or thermally activated (absorption) refrigeration device cools the inlet air through a heat exchanger. The heat exchanger in the inlet air stream causes an additional pressure drop in the air entering the compressor, thereby slightly lowering cycle power and efficiency. As the inlet air is now substantially cooler than the ambient air, there is a significant net gain in power and efficiency. Electric motor compression refrigeration entails a substantial parasitic power loss. Thermally activated absorption cooling can utilize waste heat from the microturbine, reducing the direct parasitic loss. However, the relative complexity and cost of these approaches, in comparison with evaporative cooling, make them less likely to be incorporated into microturbines.

Finally, it is also technically feasible to use thermal-energy storage systems - typically ice, chilled water, or other low-temperature fluids - to cool inlet air. These systems can substantially reduce parasitic losses from the augmented power capacity. Thermal energy storage is a viable option if on-peak power pricing only occurs a few hours a day. In that case, the shorter time of energy storage discharge and longer time for daily recharging allow for a smaller and less expensive thermal-energy storage system.

\subsection{Capital Cost}

This section provides estimates for the installed cost of microturbine systems. Two configurations are presented: power-only and CHP producing hot water for use on-site. Equipment and installation costs are estimated for the four typical microturbine systems. These are "typical" budgetary price levels. It also should be noted that installed costs can vary significantly, depending on the details of the plant equipment, geographical area, competitive 
market conditions, special site requirements, emissions control requirements, prevailing labor rates, and whether the distributed generation system is a new or retrofit application.

Table 2 provides cost estimates for combined heat and power applications. The basic microturbine package consists of the turbogenerator package and power electronics. All of the commercial and near-commercial units offer basic interconnection and paralleling functionality as part of the package cost, but utilities typically require additional safety and control hardware for interconnection. All but one of the systems offers an integrated heat exchanger, heatrecovery system for CHP within the package. Three of the current manufacturers offer an integral gas booster compressor as an option to the base package price. One manufacturer includes the GBC within the base package price. It should be noted that the package and component prices cited in the table represent manufacturer quotes or estimates. However, only two of the products have any significant market history at the time this report was prepared, while the other two are just now entering the market. The manufacturer quotes may not reflect actual manufacturing cost plus profit, but may instead represent a forward pricing strategy in which early units are sold at a loss to develop the market. The information provided for each sample system is as follows:

- $30 \mathrm{~kW}$ - Single unit $\$ 1,100 / \mathrm{kW}$, DC-to-AC inverter, basic electronic interconnection hardware, but without a heat recovery heat exchanger. Additional cost for integral fuel gas compressor. Prices are expected to be lower for volume purchases.

- $\quad 70 \mathrm{~kW}$ - Price of $\$ 1,070 / \mathrm{kW}$ includes integral heat recovery heat exchanger, fuel gas compressor, and generator with basic controls and interconnection hardware (standard 3,600rpm AC generator).

- $80 \mathrm{~kW}$ - Price of $\$ 1,000 / \mathrm{kW}$ includes integral heat recovery heat exchanger, DC-to-AC inverter, and basic electronic interconnection hardware. Additional costs for integral fuel gas compressor.

- $100 \mathrm{~kW}-$ A price of $\$ 920 / \mathrm{kW}$ includes integral heat recovery heat exchanger, DC-to-AC inverter, and basic interconnection hardware. Additional costs for integral fuel gas compressor.

The equipment cost represents the price to the ultimate customer of the microturbine package and other major components. The cost to a customer for installing a microturbine-based CHP system includes a number of other factors that increase the total costs by an estimated $60 \%$ to $70 \%$ over equipment costs. The total installed-cost estimates are based on a simple installation with minimal site preparation required. These cost estimates include provisions for grid interconnection and paralleling. Labor/materials represent the labor cost for the civil, mechanical, and electrical work and materials such as ductwork, piping, and wiring and is estimated to range from $35 \%$ to $45 \%$ of the total equipment cost. The equipment costs - plus installation labor and materials - is defined as total process capital. A number of other costs are incurred on top of total process capital. These costs are often referred to as soft costs because they vary widely by installation, by development channel, and by approach to project management. Project and construction management also includes general contractor markup and 
bonding (and performance guarantees) and is estimated to be $10 \%$ of the total equipment cost. Engineering and permitting fees are required to design the system and integrate it functionally with the application's electrical and mechanical systems and are estimated to range from $8 \%$ to $10 \%$ of the total equipment cost, depending on system size. Contingency is assumed to be $5 \%$ of the total equipment cost in all cases.

Table 2. Estimated Capital Cost for Typical Microturbine Generator Systems in Grid-Interconnected CHP Applications (2003)

\begin{tabular}{|c|c|c|c|c|}
\hline Cost Component & System 1 & System 2 & System 3 & System 4 \\
\hline Nominal Capacity (kW) & 30 & 70 & 80 & 100 \\
\hline \multirow{2}{*}{\multicolumn{5}{|c|}{$\begin{array}{l}\text { Cost }(\$ / k W) \\
\text { Equipment }\end{array}$}} \\
\hline & & & & \\
\hline Microturbine Package & 1,100 & 1,070 & 1000 & 920 \\
\hline Gas Booster Compressor & 180 & incl. & 75 & 75 \\
\hline Heat Recovery & 100 & incl. & incl. & incl. \\
\hline Add'l Controls/interconnect & 180 & 115 & 115 & 100 \\
\hline Total Equipment & 1,560 & 1,185 & 1,190 & 1,095 \\
\hline Labor/Materials & 655 & 444 & 445 & 403 \\
\hline Total Process Capital & 2,215 & 1,629 & 1,635 & 1,498 \\
\hline $\begin{array}{l}\text { Project and Construction } \\
\text { and Management }\end{array}$ & 156 & 119 & 119 & 108 \\
\hline Engineering and Fees & 156 & 95 & 95 & 88 \\
\hline Project Contingency & 109 & 83 & 83 & 75 \\
\hline Total Plant Cost (2003 \$/kW) & $\$ 2,636$ & $\$ 1,926$ & $\$ 1,932$ & $\$ 1,769$ \\
\hline
\end{tabular}

Source: Energy and Environmental Analysis, Inc., estimates based on manufacturer equipment price estimates

The capital costs will be lower for power-only systems that have no heat-recovery equipment. For the units that integrate this equipment into the basic microturbine package (the 70,80 and $100 \mathrm{~kW}$ systems); savings are projected at approximately $\$ 50 / \mathrm{kW}$ if heat recovery equipment is not installed. In addition, installation labor and materials costs are reduced (estimated to be $25 \%$ to $30 \%$ of total equipments costs) because there is no need to connect heat-recovery equipment to the application's thermal system. Engineering and permitting fees required to design the system and integrate it functionally with the application's electrical and mechanical systems are estimated to range from $8 \%$ to $10 \%$ of the total equipment cost, depending on system size. Project management and construction fees remain 10\% of total equipment costs. Contingency for power-only installations is 5\% due to reduced complexity and risk in the installation. Table 3 shows the cost estimates for power-only versions of the four microturbine systems. 
As an emerging product, the capital costs shown in the two tables represent the cost to the customer for early market entry product, but not the cost of the very first units into the market. All of the microturbine developer/manufacturers have cost-reduction plans and performanceenhancing developments for future, more mature products (see Advanced Technology Projections section).

Table 3. Estimated Capital Cost for Typical Microturbine Generator Systems in Grid-Interconnected Power-Only Applications (2003)

\begin{tabular}{|c|c|c|c|c|}
\hline Cost Component & System 1 & System 2 & System 3 & System 4 \\
\hline Nominal Capacity (kW) & 30 & 70 & 80 & 100 \\
\hline Cost $(\$ / k W)$ & & & & \\
\hline Equipment & & & & \\
\hline Microturbine Package & 1,100 & 1,070 & 1,000 & 920 \\
\hline Gas Booster Compressor & 180 & incl. & 75 & 75 \\
\hline Heat Recovery & $\mathrm{n} / \mathrm{a}$ & $\mathrm{n} / \mathrm{a}$ & $\mathrm{n} / \mathrm{a}$ & $\mathrm{n} / \mathrm{a}$ \\
\hline Controls/Monitoring & 180 & 115 & 115 & 100 \\
\hline Total Equipment & $\$ 1,460$ & $\$ 1,185$ & $\$ 1,190$ & $\$ 1,095$ \\
\hline Labor/Materials & 438 & 261 & 261 & 240 \\
\hline Total Process Capital & $\$ 1,898$ & $\$ 1,446$ & $\$ 1,451$ & $\$ 1,335$ \\
\hline $\begin{array}{l}\text { Project and Construction } \\
\text { Management }\end{array}$ & 146 & 114 & 114 & 105 \\
\hline Engineering and Fees & 146 & 91 & 91 & 84 \\
\hline Project Contingency & 73 & 57 & 57 & 52 \\
\hline Total Plant Cost $(2003 \$ / \mathrm{kW})$ & $\$ 2,263$ & $\$ 1,708$ & $\$ 1,713$ & 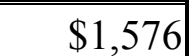 \\
\hline
\end{tabular}

Source: Energy and Environmental Analysis, Inc., estimates based on manufacturer equipment cost estimates

\subsection{Maintenance}

Microturbines are still on a learning curve in terms of maintenance, as initial commercial units have seen only two to three years of service so far. With relatively few operating hours logged for any single unit, the population of microturbines in the field has not yet yielded enough longterm operational data to allow clear definition of durability and maintenance costs.

Most manufacturers offer service contracts for maintenance priced at about $\$ 0.01$ to $\$ 0.02 / \mathrm{kWh}$. The combustor and associated hot section parts are inspected periodically. Air and oil filters are replaced periodically, and oil bearings are inspected. Microturbines operating in environments with extremely dusty air require more frequent air-filter changes. 
A microturbine overhaul is needed every 20,000 to 40,000 hours, depending on manufacturer, fuel type, and operating environment. A typical overhaul consists of replacing the main shaft with the compressor and turbine attached, general inspection and, if necessary, replacing the combustor. At the time of the overhaul, other components are examined to determine if wear has occurred, with replacements made as required.

Microturbines in peak-shaving service are usually operated with at least one on-off cycle per day. There are general concerns about the effects of this type of operation on component durability due to thermal cycling, which causes material fatigue. There is no known difference in maintenance for operation on fuels other than natural gas. However, experience with liquid fuels in industrial gas turbines suggests that liquid-fueled combustors should be inspected more frequently than natural gas-fueled combustors and may require more frequent maintenance.

\subsection{Fuels}

Microturbines have been designed to use natural gas as their primary fuel. However, they are expected to be able to operate on a wide variety of fuels, including:

- Liquid fuels (distillate oil)

- Liquefied petroleum gas (LPG) - propane and butane mixtures

- Sour gas - unprocessed natural gas as it comes directly from some gas wells

- Biogas - any of the combustible gases produced from biological degradation of organic wastes, such as landfill gas, sewage digester gas, and animal waste digester gas

- Industrial waste gases - flare gases and process off-gases from refineries, chemical plants, and steel mills

- Manufactured gases - typically low- and medium-Btu gas produced as products of gasification or pyrolysis processes.

Contaminants are a concern with most waste fuels, specifically acid gas components $\left(\mathrm{H}_{2} \mathrm{~S}\right.$, halogen acids, HCN; ammonia; salts and metal-containing compounds; organic halogen-, sulfur-, nitrogen-, and silicon-containing compounds); and oils. In combustion, halogen and sulfur compounds form halogen acids, $\mathrm{SO}_{2}$, some $\mathrm{SO}_{3}$, and possibly $\mathrm{H}_{2} \mathrm{SO}_{4}$ emissions. The acids can also corrode downstream equipment. A substantial fraction of any fuel-bound nitrogen will be oxidized into $\mathrm{NO}_{\mathrm{x}}$ in combustion. Particulates (and liquids, in the case of gaseous fuels) must be kept to very low concentrations to prevent corrosion and erosion of components. Various fuel scrubbing, droplet separation, and filtration steps will be required if any fuel contaminant levels exceed manufacturer specifications. Landfill gas, in particular, often contains chlorine compounds, sulfur compounds, organic acids, and silicon compounds, which necessitate pretreatment. 


\subsection{Availability and Life}

With the small number of units in commercial service, information is not yet sufficient to draw conclusions about reliability and availability of microturbines. The basic design and low number of moving parts hold the potential for systems of high availability; manufacturers have targeted availabilities in the range of $98 \%$ to $99 \%$. The initial projection of availability for early market microturbine systems is $95 \%+$. The use of multiple units or backup units at a site can further increase the availability of the overall facility.

The equipment life of microturbines is estimated to be 10 years; this includes at least one major overhaul over that time frame. Costs of these overhauls are included in the nonfuel maintenance estimates presented earlier in the report. Economic life of microturbine systems is typically assumed to be 10 years.

\subsection{Emission Characteristics}

Microturbines have the potential for extremely low emissions. Most current microturbines operating on gaseous fuels feature lean premixed (dry low $\mathrm{NO}_{\mathrm{x}}$, or DLN) combustor technology, which was developed relatively recently for gas turbines, but is not universally featured on larger gas turbines. Because microturbines are able to meet key emissions requirements with this or similar built-in technology, post-combustion emission control (aftertreatment) techniques are currently not needed.

The primary pollutants from microturbines are oxides of nitrogen $\left(\mathrm{NO}_{\mathrm{x}}\right)$, carbon monoxide $(\mathrm{CO})$, and unburned hydrocarbons (THC). Microturbines emit a negligible amount of sulfur dioxide $\left(\mathrm{SO}_{2}\right)$ depending on the amount of sulfur in the fuel. Microturbines using lean premix combustion are designed to achieve the objective of low emissions at full load; emissions are often higher when operating at part load.

\subsection{Control Options}

\section{Lean Premixed Combustion}

Thermal $\mathrm{NO}_{\mathrm{x}}$ formation is a function of both the local temperatures within the flame and residence time. In older combustors used in industrial gas turbines, fuel and air were separately injected into the flame zone. Such separate injections resulted in high local temperatures where the fuel and air zones intersected and most of the burning took place at stoichiometric conditions $^{19}$. The focus of combustion improvements of the past decade was to lower flame local hot-spot temperature using lean fuel/air mixtures, whereby zones of high local combustion temperatures were not created. Lean combustion decreases the fuel/air ratio in the zones where $\mathrm{NO}_{\mathrm{x}}$ production occurs, so that peak flame temperature is less than the stoichiometric flame temperature, thereby suppressing thermal $\mathrm{NO}_{\mathrm{x}}$ formation.

\footnotetext{
${ }^{19}$ Stoichiometric conditions are when the amount of oxygen in the air is sufficient for combustion of the fuel - there is no unused fuel or oxygen after combustion.
} 
Most microturbines now feature lean pre-mixed combustion systems, also referred to as dry low $\mathrm{NO}_{\mathrm{x}}(\mathrm{DLN})$ or dry low emissions (DLE). Lean, premixed combustion premixes the gaseous fuel and compressed air before they enter the combustion zone so that there are no local zones of high temperatures, or "hot spots," where high levels of $\mathrm{NO}_{\mathrm{x}}$ would form. DLN requires specially designed mixing chambers and mixture inlet zones to avoid flashback of the flame. Optimized application of DLN combustion requires an integrated approach to combustor and turbine design, and specific combustor designs must be developed for each turbine application.

$\mathrm{NO}_{\mathrm{x}}$ emissions below 9 ppmv @ 15\% $\mathrm{O}_{2}$ have been achieved with lean premixed combustion in microturbines. Most manufacturers guarantee $\mathrm{NO}_{\mathrm{x}}$ emissions of 9 to $25 \mathrm{ppmv}$ at full-load operation in their product introductions. Part-load emissions levels can be significantly higher and are an area of continued development activities.

\section{Catalytic Combustion}

In catalytic combustion, fuel is oxidized at low temperatures (typically below $1700^{\circ} \mathrm{F}$, where $\mathrm{NO}_{\mathrm{x}}$ formation is very low) in the presence of a catalyst. The catalyst is applied to a highsurface-area substrate and causes a fuel-air mixture to react and release its initial thermal energy. This initial energy (heat) stabilizes gas-phase combustion at moderate flame temperatures (as low as $2200^{\circ} \mathrm{F}$ ). Additional air or fuel can be introduced downstream of the catalyst to complete burnout and/or to achieve the desired combustor outlet design temperature. By enabling such stable low-temperature combustion, catalytic combustors emit less than $3 \mathrm{ppm} \mathrm{NO}_{\mathrm{x}}-$ with low $\mathrm{CO}$ and UHC emissions - and with low levels of vibration and acoustic noise.

Combustion system and gas turbine developers, along with the U.S. Department of Energy, the California Energy Commission, and other government agencies, are continuing to develop gas turbine catalytic combustion technology. Past efforts at developing catalytic combustors for gas turbines achieved low, single-digit $\mathrm{NO}_{\mathrm{x}} \mathrm{ppm}$ levels, but failed to produce combustion systems with suitable operating durability. This was typically due to cycling damage and to the brittle nature of the materials used for catalysts and catalyst support systems. Catalytic combustor developers and gas turbine manufacturers are testing durable catalytic and "partial catalytic" systems that are overcoming the problems of past designs. Catalytic combustors capable of achieving $\mathrm{NO}_{\mathrm{x}}$ levels below $3 \mathrm{ppm}$ are in full-scale demonstration and are entering early commercial introduction. ${ }^{20}$ As with DLN combustion, optimized catalytic combustion requires an integrated approach to combustor and turbine design. Catalytic combustors must be tailored to the specific operating characteristics and physical layout of each turbine design. Catalytic combustion may be applied to microturbines as well as industrial and utility turbines.

\footnotetext{
${ }^{20}$ For example, Kawasaki offers a version of their M1A 13X, 1.4 MW gas turbine with a catalytic combustor, with less than 3 ppm $\mathrm{NO}_{\mathrm{x}}$ guaranteed.
} 


\subsection{System Emissions}

Table 4 presents typical emissions for microturbine systems. The data shown reflect manufacturers' guaranteed levels.

Table 4. Microturbine Emission Characteristics

\begin{tabular}{|c|c|c|c|c|}
\hline Emissions Characteristics & $\begin{array}{c}\text { System } \\
1\end{array}$ & $\begin{array}{c}\text { System } \\
2\end{array}$ & $\begin{array}{c}\text { System } \\
\mathbf{3}\end{array}$ & $\begin{array}{c}\text { System } \\
4\end{array}$ \\
\hline Nominal Capacity $(\mathrm{kW})$ & 30 & 70 & 80 & 100 \\
\hline Electrical Efficiency (\%), HHV & 23 & 25 & 24 & 26 \\
\hline $\mathrm{NO}_{\mathrm{x}},\left(\mathrm{ppmv} @ 15 \% \mathrm{O}_{2}\right)$ & 9 & 9 & 25 & 15 \\
\hline $\mathrm{NO}_{\mathrm{x}}, \mathrm{lb} / \mathrm{MWh}^{21}$ & 0.51 & 0.45 & 1.25 & 0.72 \\
\hline $\mathrm{CO},(\mathrm{ppmv})$ & 40 & 9 & 50 & 15 \\
\hline $\mathrm{CO},(\mathrm{lb} / \mathrm{MWh})$ & 1.38 & 0.27 & 1.51 & 0.45 \\
\hline THC, (ppmv) & $<9$ & $<9$ & $<9$ & $<9$ \\
\hline THC, (lb/MWh) & $<0.18$ & $<0.16$ & $<0.16$ & $<0.15$ \\
\hline $\mathrm{CO}_{2},(\mathrm{lb} / \mathrm{MWh})$ & 1,765 & 1,585 & 1,650 & 1,535 \\
\hline
\end{tabular}

Note: Estimates are based on manufacturers' guarantees for typical systems commercially available in 2003; emissions estimates represent $15 \% \mathrm{O}_{2}$ using natural gas fuel

\subsection{Key Technology Objectives}

This section describes the significant technology improvements that manufacturers, researchers, and government are pursuing, which are expected to result in enhanced microturbine performance for the mid- to long-term.

\section{Technology Paths to Increased Performance}

Turbine inlet temperature is the main parameter that large gas turbine designers focus on in gas turbine technology advancement efforts. Increases in turbine inlet temperature rapidly increase the power output of the turbine - and, to a lesser extent, increase efficiency. With an increase in firing temperature, a corresponding increase in pressure ratio yields heightened benefits. Modern large gas turbines employ sophisticated methods of internal turbine cooling to permit higher temperatures without exceeding the turbine material's metallurgical creep limits. ${ }^{22}$ Microturbines, however, presently cannot take advantage of internal turbine cooling, because the complex shape of the flow passages of small radial turbines does not yet lend itself to cost-effective manufactured configurations.

\footnotetext{
${ }^{21}$ Conversion from volumetric emission rate (ppmv at $15 \% \mathrm{O}_{2}$ ) to output-based rate (lbs/MWh), for both $\mathrm{NO}_{\mathrm{x}}$ and $\mathrm{CO}$, was based on conversion multipliers provided by Catalytica Energy Systems.

(http://www.catalyticaenergy.com/xonon/emissions factors.html).

${ }^{22}$ Metals under stress at high temperatures slowly elongate and eventually break. This phenomenon is known as creep.
} 
Internal cooling of in microturbines also faces the problem of an expansion process involving a single turbine stage. Single-stage turbines result in cooling air being unavailable for subsequent power generation; cooling air cannot enter later turbine stages and provide additional power as is the case with multistage, axial turbines. Such diversion of pressurized air for cooling purposes results in efficiency and power penalties. Material advances have therefore become the preferred route to the higher temperatures that would increase microturbine efficiencies

Calculated estimates for potential efficiency and specific power of microturbines with ceramic turbines, combustor, and associated high temperature components are shown in Figures 8 and 9. These figures include the performance of microturbines with metallic turbines and firing temperatures of $1550^{\circ} \mathrm{F}$ to $1750^{\circ} \mathrm{F}$ for comparison. The performance of microturbines with ceramic components is shown over the temperature range of $2100^{\circ} \mathrm{F}$ to $2500^{\circ} \mathrm{F}$. The lowest temperature for which engineering development is worthwhile pursuing is in the $1900^{\circ} \mathrm{F}$ to $2100^{\circ} \mathrm{F}$ range. Any move to use firing temperatures above $2500^{\circ} \mathrm{F}$ are not likely until microturbines with firing temperatures below this level have proven themselves in service. At a $2500^{\circ} \mathrm{F}$ firing temperature, the expected efficiency of a microturbine would be just above the $40 \%$ (LHV) level. The figures indicate that ceramics have the potential for a significant performance gain in terms of both efficiency and specific power that, if successfully developed and deployed, would enhance the economics of microturbine systems. At some point around the range of $2400^{\circ} \mathrm{F}$ to $2500^{\circ} \mathrm{F}$, microturbine emissions may reach a limit whereby further advances are not practical without some other combustion process, such as catalytic combustion, or other novel emissions suppression technique.

Increasing turbine inlet temperature, by use of either ceramic materials or by internal turbine cooling, would also increase turbine exhaust temperature recuperator inlet temperature. In current microturbines, the recuperator inlet temperature is at, or very near, the metallurgical limit of type AISI 347 stainless steel, the generally preferred recuperator material. While alloys with higher temperature capabilities are available commercially (such as Inconel 625), such alloys are much more expensive. A forced switch to such alloys could increase microturbine cost enough to negate the value of any efficiency gains. Several alternatives are available to circumvent this potential recuperator material problem. Turbine exhaust/recuperator inlet temperature can be reduced by increasing turbine pressure ratio. Going to pressure ratios that are only slightly higher than the optimum for maximum efficiency compromises efficiency only to a small extent. Additionally, slightly higher pressure ratios than those for maximum efficiency increase specific power so that the economics of the equipment by itself may improve due to the increased power output and reduction of capital costs per net kilowatt.

The performance of internally cooled metallic turbines and ceramic turbines are similar enough that performance predictions for future ceramic turbines can be represented by those of internally cooled metallic turbines. Performance predictions for internally cooled radial inflow turbines for microturbine application would be generally similar to those for ceramic turbines but would require slightly higher turbine inlet temperature to compensate for the performance sacrifice due to the use of a small amount of compressed air for cooling. However, internally cooled radial inflow turbines are not yet available, so an accurate estimate of cooling air requirements is not available at this time. 
Figure 8. Efficiency Comparison of Microturbines w/ Metallic and Ceramic Turbines

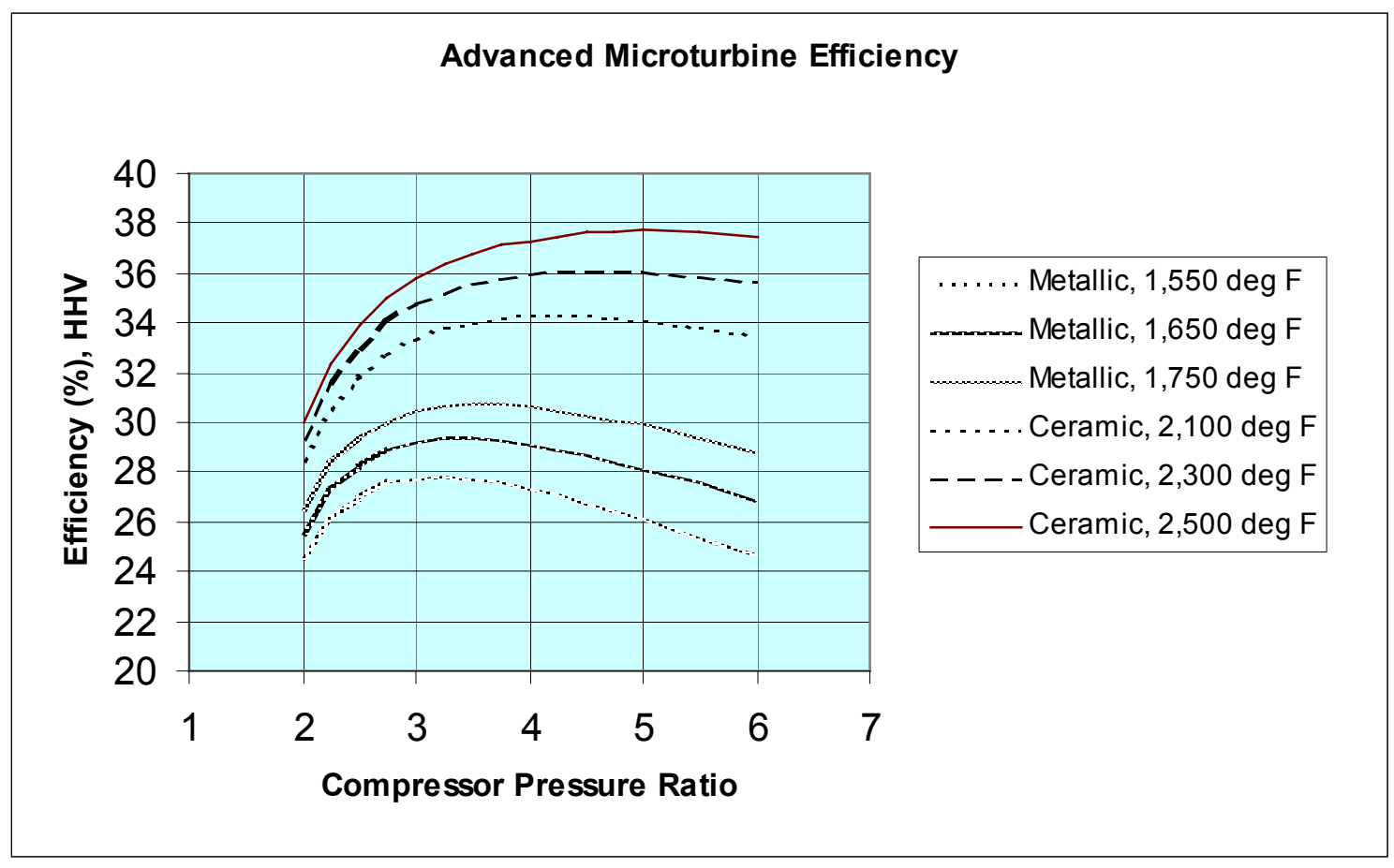

Figure 9. Specific Power Comparison of Microturbines w/ Metallic and Ceramic Turbines

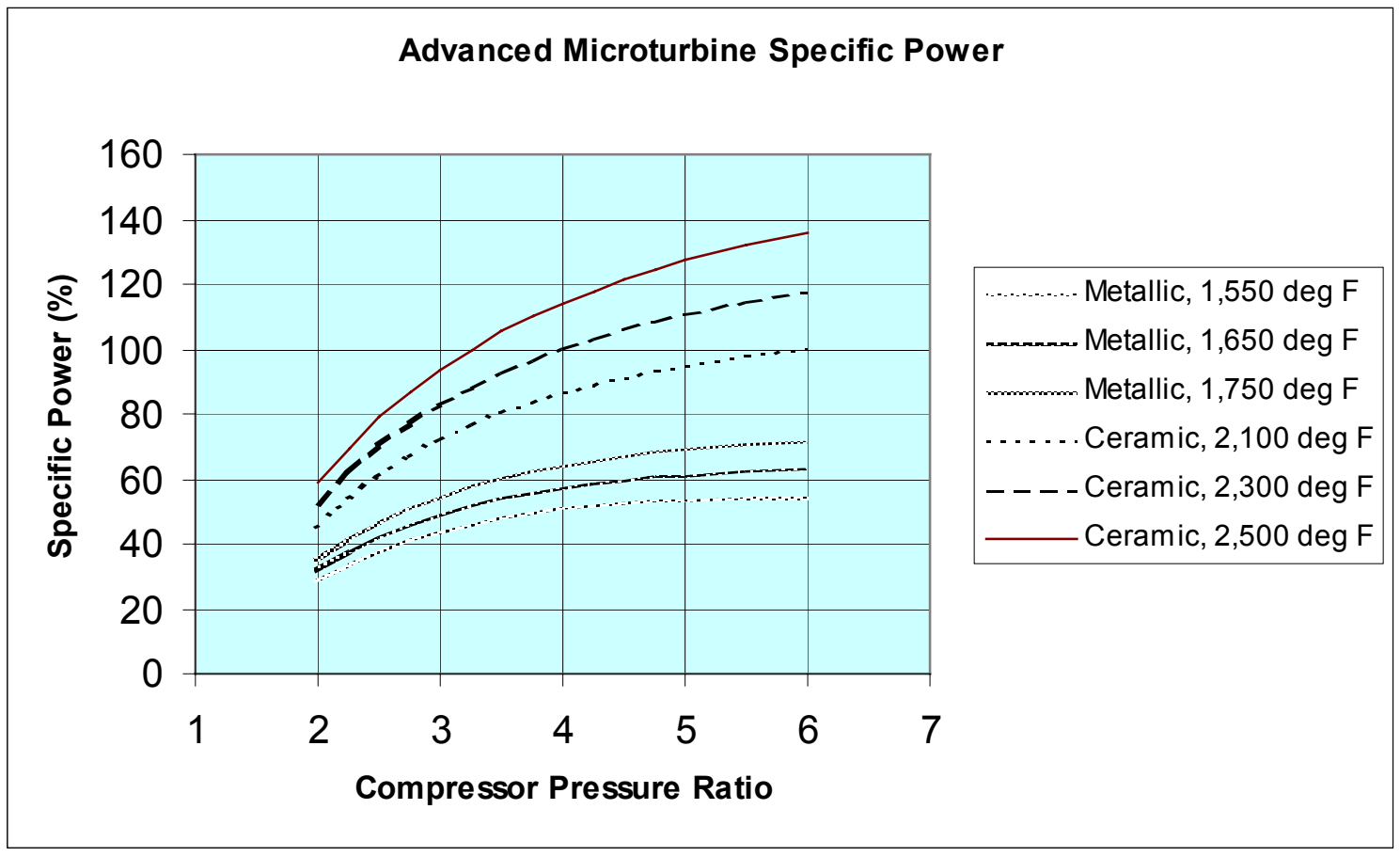


Only a limited reduction of turbine exit temperature can be accomplished by increasing the turbine pressure ratio. This limitation is due to aerodynamics, stresses resulting from centrifugal forces, and materials limitations. When greater reductions in turbine exit/recuperator inlet temperature are required, then microturbine system designers may elect to go to entirely new cycle designs such as an intercooled recuperated (ICR) cycle, with its substantially higher pressure ratio and consequentially lower recuperator inlet temperature. A microturbine ICR cycle would employ two compressors, most likely both centrifugal, which would result in a pressure ratio of 10 to 15 . Small aeronautical propulsion gas turbines have been built with two-stage centrifugal compressors. With a two-stage compressor, it would be straightforward to add an intercooler, possibly of a design and construction of the type used in turbocharged truck or marine power applications. The ICR cycle offers greater specific power as well as the ability to go to higher turbine inlet temperature without raising the recuperator inlet temperature above the capability of type AISI 347 stainless steel. Such a cycle change would present a discontinuity in efficiency and power increase and would require some machine development. It should be considered an alternative path to increased performance and reduced cost per $\mathrm{kW}$.

\section{Ceramic Materials}

Because microturbines are just now entering the market, there has been inadequate time and market pull for an advanced technology component business to develop. Thus, DOE has begun an advanced materials program for microturbines to develop ceramic turbines, combustors, recuperators, and associated high-temperature components. Ceramics allow significantly higher firing temperatures, which will enable microturbines to achieve much higher efficiencies and specific power ratings. It is unlikely that advancing the temperature of microturbines will be a slow, incremental process. Ceramic materials temperature capabilities are much higher than those of (uncooled) metallic turbines. When ceramic materials have been fully developed and proven practical for commercial turbine service, microturbine performance - in terms of both efficiency and specific power - will take a substantial step forward.

Monolithic structural ceramics for gas turbine applications have matured greatly during the past 35 years. The ceramic materials available at the beginning of the 1970s in the United States were reaction-bonded silicon nitride (RBSN), hot-pressed silicon nitride (HPSN), and reactionsintered silicon carbide (RSSC), primarily based on technology developed in Great Britain during the 1960s. These materials were relatively weak (particularly at elevated temperatures), had low fracture toughness, and were subject to time-dependent failure (creep rupture and slow crack growth). Continued improvements in powder synthesis, processing, and densification have resulted in the development of a current generation of silicon nitride ceramics, having controlled microstructures consisting of elongated grains. These so-called "self-reinforced" or "in-situ toughened" materials exhibit superior performance as reflected by increased strength, higher fracture toughness and enhanced resistance to creep rupture (lifetimes increased by 4 orders of magnitude).

Similar progress has been made in the areas of (1) component design and fabrication, (2) probabilistic design methodologies for predicting component life, and (3) nondestructive evaluation of complex-shaped parts. Because of these developments, monolithic ceramic 
components (blades and vanes) have accumulated thousands of hours under test in recent gas turbine engine demonstration programs.

Despite the experience base described above, a number of challenges remain before monolithic and composite ceramics exhibit the long lifetimes required for turbine applications. The first challenge is that of environmental degradation. The aforementioned field tests have shown that three processes can impact performance of the monolithic ceramics: (1) localized corrosion due to the presence of reactive species in the environment, (2) environmentally induced destabilization of the intergranular phases, and (3) rapid recession of the silicon nitride (or silicon carbide) due to loss of the silica scale by direct reaction with water vapor. This has led to the development of oxide-based environmental barrier coatings (EBCs), which are at an early stage of development and are the subject of substantial rig and engine testing. The second challenge, which is specific for monolithics, is that of impact resistance. Further improvements in fracture toughness may be required to ensure high reliability in the presence of foreign object damage.

As noted earlier, increasing firing temperatures also increases the temperature of the hot exhaust to the recuperator. Firing temperatures above $2000^{\circ} \mathrm{F}$ to $2100^{\circ} \mathrm{F}$ probably would require a ceramic recuperator. Development of low-cost, reliable ceramic recuperators would require a separate, intensive research and development effort in parallel to the ceramic turbine program.

\subsection{Advanced Technology Projections}

The primary challenges confronting microturbines are to reduce equipment, transaction, and installation costs in the near-term. Longer-term interrelated development priorities include achieving higher electrical efficiencies and introducing larger product sizes.

Expected improvements in microturbines for on-site power and CHP applications include:

- Reduction in equipment costs. At present microturbine package prices of $\$ 900$ to $\$ 1,100$ per $\mathrm{kW}$, microturbine economics remain marginal for many applications and regions. In industrialized countries, where microturbines are in competition with the grid and with reciprocating engines, equipment prices must approach - or be below - $\$ 500$ to $\$ 700$ per $\mathrm{kW}$ in order to achieve major market penetration. Even in developing countries or remote areas where microturbines represent a potential low-cost option for electrification, current equipment prices make them marginally competitive in many areas. While expectations remain that equipment price will decline as manufacturing volumes increase, eventually achieving an economy of scale similar to the automobile industry, the initial path to cost reduction probably will focus on improving package designs, expanding component suppliers, and reducing manufacturing costs.

- Increase in microturbine system size. Larger microturbines are under development in sizes of 200-250 kW and larger, based on perceived market requirements. Driven by both market needs and expected economies of scale, microturbines of this size will be 
better able to absorb the relatively high costs of project design, engineering, and installation experienced in the initial market introduction phase.

- Significant efficiency increases are expected, following cost-reduction efforts and size increases. Near-term efforts will include more precise manufacturing tolerances. Longerterm efforts will focus on higher firing temperatures, and employing ceramics in hot sections. Increased market penetration would provide adequately large manufacturing volumes to support incorporation of ceramic turbines, combustors, and transition pieces. Alternatively, the design of metallic radial flow turbines with internal cooling may prove practical. Either technology path would result in efficiency improvements, first to the $32 \%$ to $34 \%$ range (HHV), and later to $36 \%$ to $38 \%$ (HHV) and possibly slightly greater. Such increases in efficiency can be expected to be accompanied by cost reductions attributable to size increase, as most of the components will not increase in price as rapidly as the increased output power achievable with improved technology.

- As described in the section on emissions, development work continues on both catalytic combustion and advanced combustion techniques to reach $\mathrm{NO}_{\mathrm{x}}$ levels below 5 to $9 \mathrm{ppm}$. Catalytic combustors are just now becoming mature enough for commercial service on larger gas turbines, and further improvements in conventional combustion are expected with improved premixing and enhanced wall-cooling techniques to reduce $\mathrm{CO}$ emissions as well. The challenge with catalytic combustion is catalyst and combustor life. It is likely that one of these paths will be capable of meeting sub -5 to 9 ppm levels on a consistent basis in the future if regulations require compliance at these levels.

\section{Future Performance}

Manufacturers' data, together with a review of ongoing research and development activities, and computer thermodynamic performance modeling, have been used to create performance projections of microturbine systems through 2030. Table 5 summarizes the nature and timing of the performance advances assumed to take place from the present through 2030 that underpin the development of the projections shown in Table 6, as detailed below.

Estimates of the future performance of the microturbine CHP systems previously cited as representative systems are shown in Table 6 through 2030. These systems feature metallic turbines and hot section parts through 2005; but by 2010, all but the smallest (30 kW) unit incorporates a ceramic turbine and hot section parts. The $30 \mathrm{~kW}$ unit was selected for the last addition of ceramics because its complete installation cost is highest due to its small size. Business considerations favor investing in the product with the greatest potential for market acceptance first.

Price decreases and minor net efficiency increases are anticipated through 2005, reflecting improved package designs, increases in manufacturing volumes, and reductions in certain parasitic losses. As stated earlier, cost reduction is a critical requirement for advancing the technology. A 200 to $250 \mathrm{~kW}$ microturbine is introduced in 2005 based on a metallic turbine and 
components $^{23}$. This is upgraded to a $300 \mathrm{~kW}$ ceramic turbine in 2010 . A $500 \mathrm{~kW}$ ceramic turbine is also introduced to the market in 2010.

The ceramic machines appearing in 2010 (2020 for the $30 \mathrm{~kW}$ unit) offer dramatic efficiency improvements over present-day products, resulting from the higher firing temperatures achieved through the use of ceramic components. The levels of performance anticipated in 2010 are for initial product offerings and reflect a degree of conservatism in design, operation, and business exposure. The performance expected by 2020 or 2030 reflects the technical potential of ceramic hot-section components, and reaches or exceeds the DOE advanced microturbine system program goal of $36 \%$ HHV efficiency ( $40 \%$ LHV). The power output also increases significantly with the introduction of ceramics, resulting in higher capacity from the ceramic units. The resulting decrease in product cost per $\mathrm{kW}$ of capacity reflects not only the increase in power of a similarly sized unit, but economies of scale in manufacture, learning-curve improvements, simplification of installation and interconnection, and improvement in the economic efficiency of product distribution and sales.

The package cost estimates are based on the evaluation of the technologies and markets as described in this section. The installed cost estimates are based on package price reductions that are consistent with the improvements discussed above. The estimates also assume that, by 2030, installation labor and material costs at the site will be reduced by $25 \%$ on a total cost basis (and reduced even more per unit of output). Project management costs and markups also will be reduced as the market becomes more competitive.

Current microturbine $\mathrm{NO}_{\mathrm{x}}$ emissions are between 9 and 25 ppm. Improved combustion techniques and designs will reduce emissions to 5 to 9 ppm for all systems by 2005-2010. Catalytic combustion or further advances in conventional combustion are initially applied to microturbines in 2010, reducing emissions further.

${ }^{23}$ Such units are actually entering early commercialization in 2002/2003 
Table 5. Projected Microturbine Evolution Through 2030

\begin{tabular}{|c|c|c|c|c|c|}
\hline $\begin{array}{l}\text { Current } \\
\text { Unit }\end{array}$ & $\begin{array}{l}\text { Current } \\
\text { Characteristics }\end{array}$ & 2005 & 2010 & 2020 & 2030 \\
\hline $30 \mathrm{~kW}$ & $\begin{array}{l}\text { Metallic turbine } \\
\text { and hot-section } \\
\text { parts }\end{array}$ & $\begin{array}{l}\text { Modest price decrease due to } \\
\text { improved system design and } \\
\text { component integration. }\end{array}$ & $\begin{array}{l}\text { Price decrease due to larger } \\
\text { manufacturing volumes; } \\
\text { performance increases due } \\
\text { to component improvements } \\
\text { and tighter manufacturing } \\
\text { tolerances }\end{array}$ & $\begin{array}{l}\text { Ceramic turbine and hot- } \\
\text { section parts } \\
\text { Output increases to } 50 \mathrm{~kW} \text {, } \\
\text { reflecting significant increase } \\
\text { in firing temperature }\end{array}$ & $\begin{array}{l}\text { Incremental increases in } \\
\text { firing temperature }\end{array}$ \\
\hline $70-80 \mathrm{~kW}$ & $\begin{array}{l}\text { Metallic turbine } \\
\text { and hot-section } \\
\text { parts }\end{array}$ & $\begin{array}{l}\text { Modest price decrease due to } \\
\text { improved system design and } \\
\text { component integration; } \\
\text { performance increases due to } \\
\text { component improvements } \\
\text { and improved manufacturing } \\
\text { tolerances }\end{array}$ & $\begin{array}{l}\text { Ceramic turbine and hot } \\
\text { section parts; output } \\
\text { increases to } 110 \mathrm{~kW} \text { due to } \\
\text { significant increase in firing } \\
\text { temperature }\end{array}$ & $\begin{array}{l}\text { Incremental increases in firing } \\
\text { temperature }\end{array}$ & $\begin{array}{l}\text { Incremental increases in } \\
\text { firing temperature }\end{array}$ \\
\hline $100 \mathrm{~kW}$ & $\begin{array}{l}\text { Metallic turbine } \\
\text { and hot-section } \\
\text { parts }\end{array}$ & $\begin{array}{l}\text { Modest price decrease due to } \\
\text { improved system design and } \\
\text { component integration; } \\
\text { performance increases due to } \\
\text { component improvements } \\
\text { and improved manufacturing } \\
\text { tolerances }\end{array}$ & $\begin{array}{l}\text { Ceramic turbine and hot } \\
\text { section parts; output } \\
\text { increases to } 160 \mathrm{~kW} \text { due to } \\
\text { significant increase in firing } \\
\text { temperature. }\end{array}$ & $\begin{array}{l}\text { Incremental increases in firing } \\
\text { temperature }\end{array}$ & $\begin{array}{l}\text { Incremental increases in } \\
\text { firing temperature }\end{array}$ \\
\hline $200 \mathrm{~kW}$ & $\begin{array}{l}\text { Under } \\
\text { development }\end{array}$ & $\begin{array}{l}200 \mathrm{~kW} \text { metallic turbine } \\
\text { introduced }\end{array}$ & $\begin{array}{l}\text { Ceramic turbine and hot- } \\
\text { section parts; output } \\
\text { increases to } 300 \mathrm{~kW} \text {, } \\
\text { reflecting increased firing } \\
\text { temperature }\end{array}$ & $\begin{array}{l}\text { Incremental increases in firing } \\
\text { temperature }\end{array}$ & $\begin{array}{l}\text { Incremental increases in } \\
\text { firing temperature }\end{array}$ \\
\hline $500 \mathrm{~kW}$ & $\begin{array}{l}\text { Under } \\
\text { development }\end{array}$ & Under development & $\begin{array}{l}\text { Ceramic turbine and hot- } \\
\text { section parts }\end{array}$ & $\begin{array}{l}\text { Incremental increases in firing } \\
\text { temperature }\end{array}$ & $\begin{array}{l}\text { Incremental increases in } \\
\text { firing temperature }\end{array}$ \\
\hline
\end{tabular}


Table 6. Current and Advanced Microturbine System Characteristics ${ }^{24}$

\begin{tabular}{|c|c|c|c|c|c|}
\hline \multicolumn{6}{|c|}{$\begin{array}{l}\text { CHP Cost and Performance Projections, } \\
30 \mathrm{~kW} \text { Microturbine CHP System }\end{array}$} \\
\hline Year & Current & 2005 & 2010 & 2020 & 2030 \\
\hline Turbine Type & Metallic & Metallic & Metallic & Ceramic & Ceramic \\
\hline Nominal Capacity $^{25}$ & 30 & 30 & 30 & 50 & 50 \\
\hline Total Installed Cost $(2003 \$ / \mathrm{kW})^{26}$ & 2,262 & 2,230 & 1,870 & 1,400 & 1,250 \\
\hline O\&M Costs $(2003 \$ / k W h)^{27}$ & 0.02 & 0.018 & 0.016 & 0.014 & 0.012 \\
\hline Electrical Heat Rate (Btu/kWh) & 15,075 & 13,650 & 13,125 & 10,660 & 10,035 \\
\hline Electric Efficiency $(\%)^{28}$ & 23 & 25 & 26 & 32 & 34 \\
\hline Fuel Input (MMBtu/hr) & 0.42 & 0.41 & 0.39 & 0.53 & 0.50 \\
\hline \multicolumn{6}{|l|}{ CHP Characteristics } \\
\hline Total CHP Efficiency (\%) & 67 & 68 & 68 & 69 & 70 \\
\hline Heat Output (MMBtu/hr) & 0.19 & 0.18 & 0.17 & 0.19 & 0.18 \\
\hline Heat /Fuel Ratio & 0.44 & 0.43 & 0.42 & 0.36 & 0.36 \\
\hline Power/Heat Ratio & 0.51 & 0.58 & 0.62 & 0.88 & 0.94 \\
\hline Net Heat Rate (Btu/kWh) & 6,797 & 6,298 & 6,204 & 5,841 & 5,498 \\
\hline \multicolumn{6}{|l|}{ Emissions Characteristics } \\
\hline $\mathrm{NO}_{\mathrm{x}}(\mathrm{ppm})$ & 9 & 9 & 5 & 3 & 3 \\
\hline $\mathrm{CO}(\mathrm{ppm})$ & 40 & 40 & 30 & 20 & 20 \\
\hline THC (ppm) & $<9$ & $<9$ & $<9$ & $<9$ & $<9$ \\
\hline $\mathrm{CO}_{2}(\mathrm{lb} / \mathrm{MWh})$ & 1,765 & 1,590 & 1,525 & 1,250 & 1,174 \\
\hline
\end{tabular}

\footnotetext{
${ }^{24}$ Current-year estimates based on: Capstone Model 33030 kW, Ingersoll Rand PowerWorks 70 kW, Turbec T100 $100 \mathrm{~kW}$ systems; out-year estimates based on near-term manufacturers plans and longer-term manufacturer/DOE RD\&D goals.

${ }^{25}$ Capacity increases significantly in the transition from metallic to ceramic turbine; increased capacity results in decreased specific costs $(\$ / \mathrm{kW})$; higher turbine inlet temperatures result in higher efficiencies.

${ }^{26}$ Installed costs based on CHP system producing hot water from exhaust heat recovery. The $70 \mathrm{~kW}$ and $100 \mathrm{~kW}$ systems are currently offered with integral hot water recovery built into the equipment. The $30 \mathrm{~kW}$ units are currently built as power-only generators, and the heat-recovery water heater is a separate unit. Other units entering the market are expected to feature built-in, heat-recovery water heaters.

${ }^{27}$ Nonfuel O\&M costs are based on manufacturers' estimates for current year and are projected to decrease as a sales and service infrastructure develops; O\&M costs for ceramic turbines are estimated to be high at introduction, and to decrease as ceramics are further deployed.

${ }^{28}$ Electrical efficiencies are net of parasitic and conversion losses. Fuel-gas compressor needs based on 1 psi inlet supply.
} 
Table 6. (cont'd.) Current and Advanced Microturbine System Characteristics

\begin{tabular}{|c|c|c|c|c|c|}
\hline \multicolumn{6}{|l|}{$\begin{array}{l}\text { Cost and Performance Projections, } \\
70 \mathrm{~kW} \text { Microturbine CHP System }\end{array}$} \\
\hline Year & Current & 2005 & 2010 & 2020 & 2030 \\
\hline Turbine Type & Metallic & Metallic & Ceramic & Ceramic & Ceramic \\
\hline Nominal Capacity & 70 & 70 & 110 & 110 & 110 \\
\hline Total Installed Cost $(2003 \$ / \mathrm{kW})$ & 1,926 & 1,725 & 1,435 & 1,091 & 995 \\
\hline O\&M Costs $(2003 \$ / \mathrm{kWh})$ & 0.015 & 0.014 & 0.013 & 0.012 & 0.01 \\
\hline Electrical Heat Rate (Btu/kWh) & 13,545 & 13,025 & 10,665 & 9,750 & 9,225 \\
\hline Electric Efficiency (\%) & 25 & 26 & 32 & 35 & 37 \\
\hline Fuel Input (MMBtu/hr) & 0.91 & 0.90 & 1.17 & 1.07 & 1.01 \\
\hline \multicolumn{6}{|l|}{\begin{tabular}{|l|} 
CHP Characteristics \\
\end{tabular}} \\
\hline Total CHP Efficiency (\%) & 61 & 61 & 61 & 64 & 66 \\
\hline Heat Output (MMBtu/hr) & 0.33 & 0.31 & 0.34 & 0.31 & 0.29 \\
\hline Heat /Fuel Ratio & 0.36 & 0.35 & 0.29 & 0.29 & 0.29 \\
\hline Power/Heat Ratio & 0.70 & 0.75 & 1.11 & 1.21 & 1.28 \\
\hline Net Heat Rate (Btu/kWh) & 7,485 & 7,325 & 6,814 & 6,230 & 5,895 \\
\hline \multicolumn{6}{|l|}{ Emissions Characteristics } \\
\hline $\mathrm{NO}_{\mathrm{x}}(\mathrm{ppm})$ & 9 & 9 & 5 & 3 & 3 \\
\hline $\mathrm{CO}(\mathrm{ppm})$ & 9 & 9 & 9 & 9 & 9 \\
\hline THC (ppm) & $<9$ & $<9$ & $<9$ & $<9$ & $<9$ \\
\hline $\mathrm{CO}_{2}(\mathrm{lb} / \mathrm{MWh})$ & 1,585 & 1,525 & 1,250 & 1140 & 1,080 \\
\hline
\end{tabular}


Table 6. (cont'd.) Current and Advanced Microturbine System Characteristics

\begin{tabular}{|c|c|c|c|c|c|}
\hline \multicolumn{6}{|l|}{$\begin{array}{l}\text { Cost and Performance Projections, } \\
100 \mathrm{~kW} \text { Microturbine CHP System }\end{array}$} \\
\hline Year & Current & 2005 & 2010 & 2020 & 2030 \\
\hline Turbine Type & Metallic & Metallic & Ceramic & Ceramic & Ceramic \\
\hline Nominal Capacity & 100 & 100 & 160 & 160 & 160 \\
\hline Total Installed Cost $(2003 \$ / \mathrm{kW})$ & 1,769 & 1,585 & 1,245 & 900 & 845 \\
\hline O\&M Costs $(2003 \$ / \mathrm{kWh})$ & 0.015 & 0.015 & 0.014 & 0.012 & 0.01 \\
\hline Electrical Heat Rate (Btu/kWh) & 13,125 & 11,770 & 9,480 & 8,980 & 8,750 \\
\hline Electric Efficiency (\%) & 26 & 29 & 36 & 38 & 39 \\
\hline Fuel Input (MMBtu/hr) & 1.31 & 1.18 & 1.52 & 1.44 & 1.40 \\
\hline \multicolumn{6}{|l|}{ CHP Characteristics } \\
\hline Total CHP Efficiency (\%) & 62 & 62 & 64 & 66 & 67 \\
\hline Heat Output (MMBtu/hr) & 0.47 & 0.41 & 0.45 & 0.41 & 0.39 \\
\hline Heat /Fuel Ratio & 0.35 & 0.35 & 0.30 & 0.29 & 0.28 \\
\hline Power/Heat Ratio & 0.73 & 0.83 & 1.21 & 1.33 & 1.38 \\
\hline Net Heat Rate (Btu/kWh) & 7,300 & 6,650 & 5,995 & 5,780 & 5,670 \\
\hline \multicolumn{6}{|l|}{ Emissions Characteristics } \\
\hline $\mathrm{NO}_{\mathrm{x}}(\mathrm{ppm})$ & 15 & 9 & 5 & 3 & 3 \\
\hline $\mathrm{CO}(\mathrm{ppm})$ & 15 & 15 & 15 & 9 & 9 \\
\hline THC (ppm) & $<9$ & $<9$ & $<9$ & $<9$ & $<9$ \\
\hline $\mathrm{CO}_{2}(\mathrm{lb} / \mathrm{MWh})$ & 1,535 & 1,375 & 1,110 & 1,050 & 1,025 \\
\hline
\end{tabular}


Table 6. (cont'd.) Current and Advanced Microturbine System Characteristics

\begin{tabular}{|c|c|c|c|c|c|}
\hline \multicolumn{6}{|l|}{$\begin{array}{l}\text { Cost and Performance Projections, } \\
200 \mathrm{~kW} \text { Microturbine CHP System }\end{array}$} \\
\hline Year & Current & 2005 & 2010 & 2020 & 2030 \\
\hline Turbine Type & - & Metallic & Ceramic & Ceramic & Ceramic \\
\hline Nominal Capacity & - & 200 & 300 & 300 & 300 \\
\hline Total Installed Cost $(2003 \$ / \mathrm{kW})$ & - & 1,620 & 1,415 & 870 & 765 \\
\hline O\&M Costs $(2003 \$ / \mathrm{kWh})$ & - & 0.015 & 0.014 & 0.012 & 0.01 \\
\hline Electrical Heat Rate (Btu/kWh) & - & 11,375 & 9,480 & 8,980 & 8,750 \\
\hline Electric Efficiency (\%) & - & 30 & 36 & 38 & 39 \\
\hline Fuel Input (MMBtu/hr) & - & 2.27 & 2.84 & 2.24 & 2.19 \\
\hline \multicolumn{6}{|l|}{ CHP Characteristics } \\
\hline Total CHP Efficiency (\%) & - & 63 & 63 & 65 & 66 \\
\hline Heat Output (MMBtu/hr) & - & 0.74 & 0.78 & 0.61 & 0.60 \\
\hline Heat/Fuel Ratio & - & 0.32 & 0.27 & 0.27 & 0.27 \\
\hline Power/Heat Ratio & - & 0.92 & 1.32 & 1.40 & 1.43 \\
\hline Net Heat Rate (Btu/kWh) & - & 6,755 & 6,240 & 5,935 & 5,770 \\
\hline \multicolumn{6}{|l|}{ Emissions Characteristics } \\
\hline $\mathrm{NO}_{\mathrm{x}}(\mathrm{ppm})$ & - & 9 & 5 & 3 & 3 \\
\hline $\mathrm{CO}(\mathrm{ppm})$ & - & 9 & 9 & 9 & 9 \\
\hline THC (ppm) & - & $<9$ & $<9$ & $<9$ & $<9$ \\
\hline $\mathrm{CO}_{2}(\mathrm{lb} / \mathrm{MWh})$ & - & 1,330 & 1,110 & 1,050 & 1,025 \\
\hline
\end{tabular}


Table 6. (cont'd.) Current and Advanced Microturbine System Characteristics

\begin{tabular}{|l|c|c|c|c|c|}
\hline Cost and Performance Projections, \\
$\mathbf{5 0 0}$ kW Microturbine CHP System & Current & $\mathbf{2 0 0 5}$ & $\mathbf{2 0 1 0}$ & $\mathbf{2 0 2 0}$ & $\mathbf{2 0 3 0}$ \\
\hline Year & - & - & Ceramic & Ceramic & Ceramic \\
Turbine Type & - & - & 500 & 500 & 500 \\
Nominal Capacity & - & - & 1,150 & 770 & 660 \\
Total Installed Cost (2003 \$/kW) & - & - & 0.015 & 0.012 & 0.01 \\
O\&M Costs (2003 \$/kWh) & - & - & 9,480 & 8,750 & 8,530 \\
Electrical Heat Rate (Btu/kWh) & - & - & 36 & 39 & 40 \\
Electric Efficiency (\%) & - & - & 4.74 & 4.37 & 4.27 \\
Fuel Input (MMBtu/hr) & - & & & & \\
\hline CHP Characteristics & - & - & 66 & 67 & 68 \\
\hline Total CHP Efficiency (\%) & - & - & 1.43 & 1.24 & 1.18 \\
Heat Output (MMBtu/hr) & - & - & 0.30 & 0.28 & 0.28 \\
Heat/Fuel Ratio & - & - & 1.20 & 1.38 & 1.44 \\
Power/Heat Ratio & - & - & 5,915 & 5,650 & 5,570 \\
Net Heat Rate (Btu/kWh) & & & & & \\
\hline Emissions Characteristics & - & - & 5 & 3 & 3 \\
\hline NO $($ ppm) & - & - & 9 & 9 & 9 \\
CO (ppm) & - & - & $<9$ & $<9$ & $<9$ \\
THC (ppm) & - & - & 1,110 & 1,025 & 1,000 \\
CO (lb/MWh) & & & & & \\
\hline
\end{tabular}




\subsection{References}

Benson, B.; SCS Energy, Experience with Capstone and Ingersoll Rand Microturbines using Waste Fuels, DOE/CETC/CANDRA Workshop, Calgary, Alberta, Canada, January 21-24, 2003

Brandon, R.; CETC, Microturbine CHP Installation, DOE/CETC/CANDRA Workshop, Calgary, Alberta, Canada, January 21-24, 2003

Cambridge Energy Research Associates; The Next Generation: Fuel Cells and Microturbines, January 1998

Energy and Environmental Analysis, Inc.; Assessment of Emission Control Technologies for Distributed Resource Options, GRI/EPRI Report, GRI-99/064, 1999.

Energy Nexus Group, Performance and Cost Trajectories of Clean Distributed Generation Technologies, Prepared for The Energy Foundation, May 29, 2002.

Energetics, Inc; Summary of the Microturbine Technology Summit, summary report for U.S. DOE, DOE/ORO 2081, Orlando, FL, December 1998.

McDonell, V.; University of California - Irvine, Microturbine Installation and Operational Experience, DOE/CETC/CANDRA Workshop, Calgary, Alberta, Canada, January 21-24, 2003

Sheldon, K.; GE Global Research, GE Advanced Integrated Microturbine System Program, DOE/CETC/CANDRA Workshop, Calgary, Alberta, Canada, January 21-24, 2003

Van Holde, D.; E-Source, Microturbines: Lessons from Early Adopters, Platts Research and Consulting, December 2002

Venture Development Corporation; Grid Power Solutions: The North American Market for Distributed Generation and Ride-Through Technologies

Whithead, T, Enbridge Gas, Brandon, R., CETC; Direction of Microturbine Compressors, DOE/CETC/CANDRA Workshop, Calgary, Alberta, Canada, January 21-24, 2003

Microturbine manufacturers:

Bowman Power Limited, www.bowmanpower.com

Capstone Turbines, Inc., www.microturbine.com

Elliott Energy Systems, www.tapower.com

Ingersoll Rand Energy Systems, www.irco.com

Turbec Inc., www.turbec.com 


\section{Fuel Cell Systems}

\subsection{Overview}

Fuel cell systems, currently in the early stages of commercialization, are an entirely different approach to the production of electricity from traditional prime mover technologies. Fuel cells are similar to batteries, in that both produce a direct current (DC) through an electrochemical process without direct combustion of a fuel source. However, whereas a battery delivers power from a finite amount of stored energy, fuel cells can operate indefinitely if a fuel and oxidant are continuously supplied. Charged ions pass through an electrolyte between two electrodes (a cathode and an anode) to generate electricity. In many fuel cells, a catalyst enhances the cell's electric power production capability.

Fuel cells have the potential for clean, quiet, and very efficient power generation - benefits that have driven significant investment in their development in the past two decades. As with most new technologies, fuel cell systems face a number of formidable market-entry issues resulting from product immaturity, system complexities, and unproven product durability and reliability. These translate into high capital cost, lack of support infrastructure, and technical risk for early adopters. While the future of fuel cells holds many unknowns, the many advantages of fuel cells suggest that they have the potential to significantly change how electricity is produced.

Sir William Grove, who demonstrated a hydrogen fuel cell in London in the 1830s, invented what is known today as fuel cell technology. Grove's technology was set aside for more than 100 years without practical application. Fuel cells returned to the laboratory in the 1950 s, when power systems were being developed for the U.S. space program. Today, the topic of fuel cells encompasses a broad range of different technologies, technical issues, and market dynamics. Significant amounts of public and private investment are being applied to the development of fuel cells for applications in the power-generation and automotive industries.

There are five primary types of fuel cells, four of which are under development. The types are differentiated by the type of electrolyte material they use. They are: 1) phosphoric acid (PAFC), 2) proton exchange membrane (PEMFC) - often referred to as a polymer electrolyte membrane, 3) molten carbonate (MCFC), 4) solid oxide (SOFC), and 5) alkaline fuel cell (AFC). Operating temperatures range from near-ambient to $1800^{\circ} \mathrm{F}$. Electrical-generating efficiencies range from $30 \%$ to more than $50 \%$ HHV. ${ }^{1}$ The four types of fuel cells can have very different performance characteristics, advantages, and limitations, and therefore will be suited to a wide variety of distributed generation applications.

\footnotetext{
${ }^{1}$ Unless otherwise noted, efficiencies quoted in this report are based on higher heating value (HHV), which includes the heat of condensation of the water vapor in the combustion products. In engineering and scientific literature, the lower heating value (LHV - which does not include the heat of condensation of the water vapor in the products) is often used. The HHV is greater than the LHV by approximately $10 \%$ with natural gas as the fuel (i.e., $50 \%$ LHV versus $45 \% \mathrm{HHV})$.
} 
The different fuel cell types share certain important characteristics. First, fuel cells are not thermal energy-based (Carnot-cycle) engines. A Carnot-cycle engine is a theoretical construct that represents the absolute maximum amount of useful work that can be obtained from a heatdriven engine, which uses heat at one temperature and rejects heat at a lower temperature. Because fuel cells are not heat-driven engines, they are not limited to the efficiency of Carnot engines. Instead, they use an electrochemical or battery-like process to convert the chemical energy of hydrogen into water and electricity. Fuel cells can, in theory, achieve extremely high electrical efficiencies. The second shared feature is that they use hydrogen as their fuel, which may be derived from a hydrocarbon source such as natural gas or may be created from water in a renewable-driven electrolysis process. Third, each fuel cell system is composed of three primary subsystems: 1) the fuel processor, which converts the natural gas into a hydrogen-rich feed stream (this can be integrated into the fuel cell stack in certain fuel cell configurations); 2) the fuel cell stack, which generates direct current electricity; and 3) the power conditioner, which processes the electric energy into alternating current or regulated direct current. Finally, all types of fuel cells have very low $\mathrm{NO}$ emissions because the only combustion processes are the reforming of natural gas or other fuels to produce hydrogen and the burning of a low-energy hydrogen exhaust stream that is used to heat the fuel processor.

A fuel cell contains two electrodes (anode and cathode) separated by an electrolyte (catalyst). To produce a usable quantity of electricity, individual cells (anode, electrolyte and cathode) are assembled in a stack of repeating interconnected components. Several OEMs offer commercial fuel cell stacks for specialized applications. This report focuses on integrated fuel cell systems (i.e., one or more fuel cell stacks, a fuel processor, and power electronics) under development for distributed generation applications. Today, there is only one commercially available fuel cell system with sustained field operational history for distributed generation applications, a $200 \mathrm{~kW}$ PAFC unit ${ }^{2}$ that has been commercially offered since 1992 . With more than 250 units sold, PAFCs have achieved more than 6 million operating hours ${ }^{3}$ in a variety of applications. These range from a New York City police station, to a major postal facility in Alaska, to a credit cardprocessing system in Nebraska. Installed in 19 countries, this initial commercial fuel cell product has successfully introduced the capabilities and features of fuel cells into the distributed generation marketplace. Although nearly two dozen companies are currently field-testing a variety of fuel cell systems for market entry, the commercial availability of a wide array of offthe-shelf, fully warranted fuel cell systems designed for broad customer classes is still several years away. For this reason, many of the performance parameters cited in this report must be regarded as development or demonstration targets rather than validated characteristics.

\subsection{Applications}

Fuel cell systems are envisioned to serve a variety of distributed generation applications and markets. The $200 \mathrm{~kW}$ PAFC has established benchmarks for all competing technologies. Its 40,000-hour cell stack life and 9,600 hours of continuous nonstop operation have set the standard for durability and reliability. However, there is still only limited experience that can be used to validate their use in those applications considered most competitive for fuel cells, in comparison

\footnotetext{
${ }^{2}$ Offered by UTC Fuel Cells as the PC25.

${ }^{3} 6.3$ million hours as of September 9, 2003, per the UTC Web site: http://www.utcfuelcells.com/ 
to alternate prime movers, such as reciprocating engines and gas turbines. At this stage of development and early commercial use, fuel cells have high capital cost and high project risk due to as yet unproven durability and reliability. Early markets and applications will be those that are most tolerant of risk and cost.

In distributed generation markets, the primary characteristic driving early market acceptance has been the ability of fuel cell systems to provide power quality and reliability benefits. Also, they are able to achieve high efficiencies over a broad load profile and very low emissions without additional controls. Most of the 200-plus commercially operational fuel cells have been configured as combined heat and power units to improve overall economics.

Potential applications for fuel cell systems include combined heat and power (CHP), premium power, remote power, grid support, and a variety of specialty applications that can benefit from the high efficiency and low emissions characteristics of the technology. High capital cost keeps fuel cells from being viable options for most standby power and peak-shaving applications. Long start-up times for high-temperature fuel cells also diminish their value for standby applications.

\subsection{Power-Only}

\section{Premium Power}

Consumers who require higher levels of reliability or power quality - and are willing to pay for it - often find some form of distributed, on-site generation to be advantageous. These consumers are typically less concerned about the initial prices of power-generating equipment than other types of consumers. In the premium power market, the current high prices of fuel cell systems may be justified by their higher efficiency, low emissions, reduced vibration and noise, potential for high availability and reliability, good power quality, and compatibility with zoning restrictions. Fuel cell systems can be designed for both indoor and outdoor installation, in close proximity to sensitive environments, people, or animals.

\section{Remote Power}

In locations where power from the local grid is unavailable or extremely expensive to install, fuel cells can be a competitive option. As with premium power, remote power applications are generally load-following operations with extended operating hours. As a result, on a long-term basis, emissions and fuel-use efficiency become more significant criteria in much of the remote power DG market. Coupled with their other potential advantages, fuel cell systems can provide competitive energy services into certain segments of the remote power market.

\section{Grid Support}

One of the first applications that drew the attention of electric utilities to fuel cell technologies was grid support - that is, the strategic placement of small power generators in local areas where power demand is high, but where it is not economic to increase the capacity of the power grid. Numerous examples of utility-owned and -operated distributed generating systems are found in the U.S. and abroad. The primary application in the United States has been the use of relatively large diesel or natural gas engines for peaking or intermediate load service at municipal utilities 
and electric cooperatives. Such installations can defer the need for transmission and distribution system expansion, can provide temporary peaking capacity within constrained areas, or be used for system power factor correction and voltage support, thereby reducing costs for both customers and the utility system. One unique capability that fuel cell systems offer is the ability to operate almost independently of the fuel cell to correct power factors and harmonic characteristics in support of the grid.

\subsection{Combined Heat and Power}

Combined heat and power (CHP) applications recover and use the byproduct heat from on-site power generation equipment. The economics of on-site generation applications for fuel cells are enhanced by their continuous baseload operation and by the use of byproduct heat from the fuel cell system.

Heat can generally be recovered in the form of hot water or low-pressure steam ( $<30 \mathrm{psig})$, but the quality (temperature level) of the heat is dependent on the type of fuel cell and its operating temperature. For example, PEMFCs currently operate at temperatures below $200^{\circ} \mathrm{F}$, and therefore can provide only low-quality heat. PAFCs operate at $400^{\circ} \mathrm{F}$ and offer both $140^{\circ} \mathrm{F}$ and $250^{\circ} \mathrm{F}$ heat-recovery options ${ }^{4}$. Generally, the heat recovered from these fuel cell CHP systems is appropriate for low-temperature process needs, space heating and cooling (with an absorption chiller), and water heating. SOFC and MCFC technologies can generate medium-pressure steam (up to about $150 \mathrm{psig}$ ) from the fuel cell's high-temperature exhaust gas, but much of the exhaust gas heat is usually used to heat the inlet process gases.

Commercial/institutional buildings and light industrial facilities with adequate electrical loads, as well as space heating and hot water requirements, appear to be best suited for fuel cell CHP applications. The simplest thermal load to supply is hot water. Primary applications for fuel cell CHP in the commercial/institutional sectors are in buildings with relatively high and coincident electric and hot water demand, such as colleges and universities, hospitals and nursing homes, and lodging. Office buildings and certain warehousing and mercantile/service applications can be applications for the high efficiency fuel cell CHP system because noise and emissions are often critical siting considerations. Technology development efforts for engine-driven systems targeted at heat-activated cooling/refrigeration and thermally regenerated desiccants will also broaden fuel cell CHP applications by increasing thermal energy use in certain building types such as restaurants, supermarkets, offices and refrigerated warehouses.

\subsection{Technology Description}

Fuel cells produce direct current electricity through an electrochemical process, much like a standard battery. However, unlike a standard battery, the fuel cell reactants are continuously replenished. The reactants, most typically hydrogen and oxygen, are fed into the fuel cell, and power is generated as long as these reactants are supplied. The hydrogen $\left(\mathrm{H}_{2}\right)$ is typically generated from a hydrocarbon fuel such as natural gas or LPG. The oxygen $\left(\mathrm{O}_{2}\right)$ is obtained from the air.

${ }^{4}$ www.utcfuelcells.com/commercial/pc25summary.shtml 


\subsection{Basic Process and Components}

A natural gas-fired fuel cell system consists of three primary subsystems: 1) the fuel processor that converts the natural gas into a hydrogen-rich feed stream; 2) the fuel cell stack that generates direct current electricity; and 3) the power conditioner, which processes the electric energy into alternating current or regulated direct current.

Figure 1. Fuel Cell Electrochemical Process

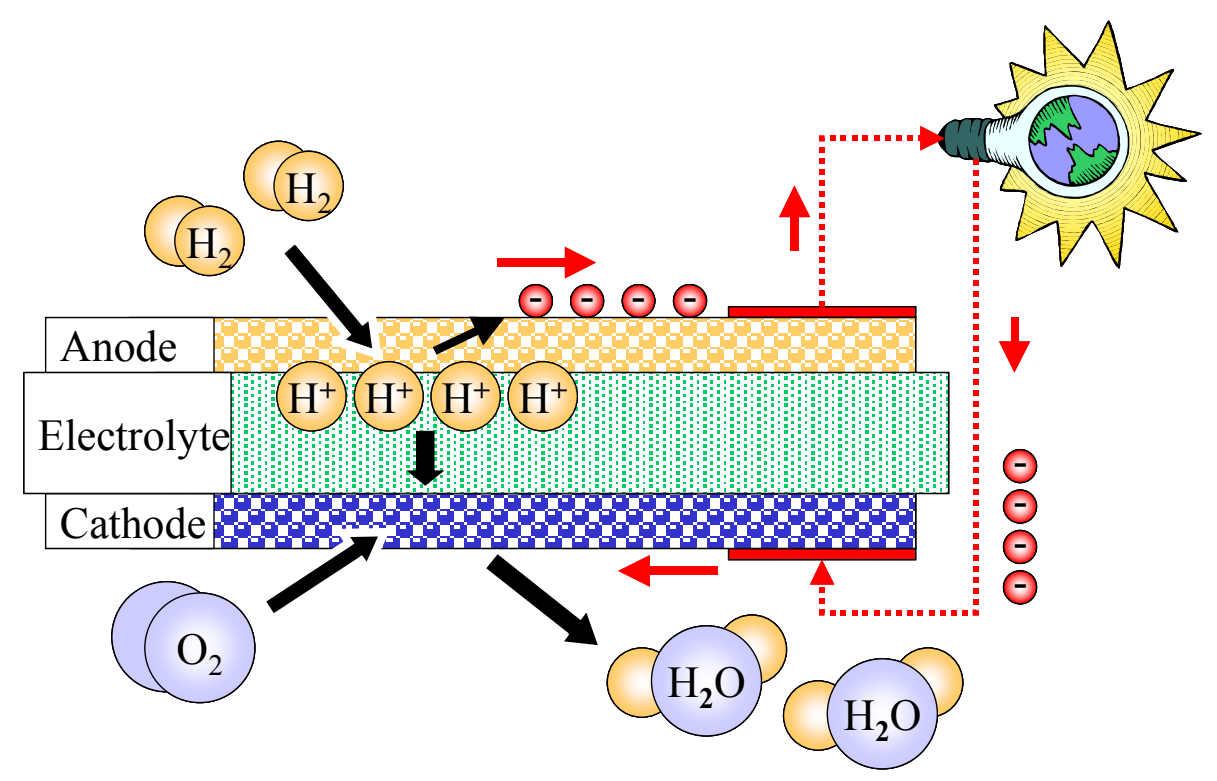

Source: Energy and Environmental Analysis, Inc.

Figure 1 illustrates the electrochemical process in PAFCs and PEMFCs. The fuel cell consists of a cathode (positively charged electrode), an anode (negatively charged electrode), and an electrolyte. Figure 1 shows the cell connected to an external load. The anode provides an interface between the fuel and the electrolyte, catalyzes the fuel reaction, and provides a path through which free electrons are conducted to the load via the external circuit. The cathode provides an interface between the oxygen and the electrolyte, catalyzes the oxygen reaction, and provides a path through which free electrons are conducted from the load via the external circuit. The electrolyte, an ionically conductive (but not electrically conductive) medium, acts as the separator between hydrogen and oxygen to prevent mixing and the resultant direct combustion. It completes the electrical circuit by transporting hydrogen ions from the anode to the cathode.

The hydrogen and oxygen are fed to the anode and cathode, respectively. The hydrogen and oxygen gases do not mix directly, and combustion does not occur. Instead, the hydrogen is oxidized with the help of a catalyst. Because the reaction does not take place at very high temperatures, there is no opportunity for the formation of $\mathrm{NO}_{\mathrm{x}}$.

At the anode, the hydrogen gas is electrochemically dissociated (in the presence of a catalyst) into hydrogen ions $\left(\mathrm{H}^{+}\right)$and free electrons $\left(\mathrm{e}^{-}\right)$.

Anode Reaction: $\quad 2 \mathrm{H}_{2} \rightarrow 4 \mathrm{H}^{+}+4 \mathrm{e}^{-}$ 
The electrons flow out of the anode through an external electrical circuit. The hydrogen ions flow into the electrolyte layer and eventually to the cathode, driven by their concentration. At the cathode, the oxygen gas is electrochemically combined (in the presence of a catalyst) with the hydrogen ions and free electrons to generate water.

$$
\text { Cathode Reaction: } \quad \mathrm{O}_{2}+4 \mathrm{H}^{+}+4 \mathrm{e}^{-} \rightarrow 2 \mathrm{H}_{2} \mathrm{O}
$$

The overall reaction in a fuel cell is as follows:

$$
\text { Net Fuel Cell Reaction: } \quad 2 \mathrm{H}_{2}+\mathrm{O}_{2} \rightarrow 2 \mathrm{H}_{2} \mathrm{O} \text { (vapor) + Energy }
$$

The amount of work that is available is equal to the difference between the Gibbs free energy ${ }^{5}$ of the product and the Gibbs free energy of the reactants.

As power is generated, electrons flow through the external circuit, ions flow through the electrolyte layer, and chemicals flow into and out of the electrodes. Each process has natural resistances that must be overcome, which reduces the operational cell voltage below the theoretical (open-circuit) potential. There are also irreversibilities ${ }^{6}$ that affect actual potentials. Some of the chemical potential energy is converted into heat, and resistance heat is generated along with the power. The electrical power (Watts) generated by the fuel cell is the product of the current measured in amperes and the operational voltage. The quantity of heat generated within the fuel cell is the product of the current and the difference between the theoretical maximum potential and the actual operating voltage. A typical operating fuel cell will have a voltage between 0.55 and 0.80 volts. In most cases, the water produced by the fuel cell reactions exits the fuel cell as vapor. The reaction of hydrogen and oxygen to produce water vapor has a theoretical potential of 1.23 volts. Therefore, the 1.23 -volt LHV theoretical potential is used to estimate sensible heat generated by the fuel cell electrochemical process.

The electrical efficiency of the cell is the ratio of the power generated to the heating value of the hydrogen consumed. Because the consumption of a given amount of hydrogen will always generate the same electric current, the ratio of the operating voltage to the theoretical maximum of 1.48 volts (for a hydrogen-oxygen cell that condenses the water produced) usually represents the stack electrical efficiency on a higher heating value $\left(\mathrm{HHV}^{7}\right)$ basis. For cells that do not condense the water produced, the theoretical maximum voltage is 1.23 volts - and the LHV efficiency is the ratio of the actual operating voltage to 1.23 . The maximum thermodynamic efficiency of a hydrogen fuel cell is the ratio of the Gibbs free energy and the heating value of the hydrogen. The Gibbs free energy decreases with increasing temperatures, because the product water produced at the elevated temperature of the fuel cell includes the sensible heat at

\footnotetext{
${ }^{5}$ Gibbs free energy is defined as the maximum amount of work that is available from a chemical reaction.

${ }^{6}$ Irreversibilities are changes in the chemical's potential energy that are not reversible through the electrochemical process. Typically, some of the potential energy is converted into heat even at open circuit conditions when current is not flowing. A simple example is the resistance to ionic flow through the electrolyte while the fuel cell is operating. This potential energy "loss" is really a conversion to heat energy, which cannot be reconverted into chemical energy directly within the fuel cell.

${ }^{7}$ Most of the efficiencies quoted in this report are based on higher heating value (HHV), which includes the heat of condensation of the water vapor in the products.
} 
that temperature, and this energy cannot be converted into electricity without the addition of a thermal energy conversion cycle (such as a steam turbine). Therefore, the maximum efficiency of a fuel cell stack decreases with increasing temperature. However, when combined into a complete fuel cell power plant that includes fuel processing, the higher temperature technologies - through functional integration - provide higher overall net electrical efficiencies.

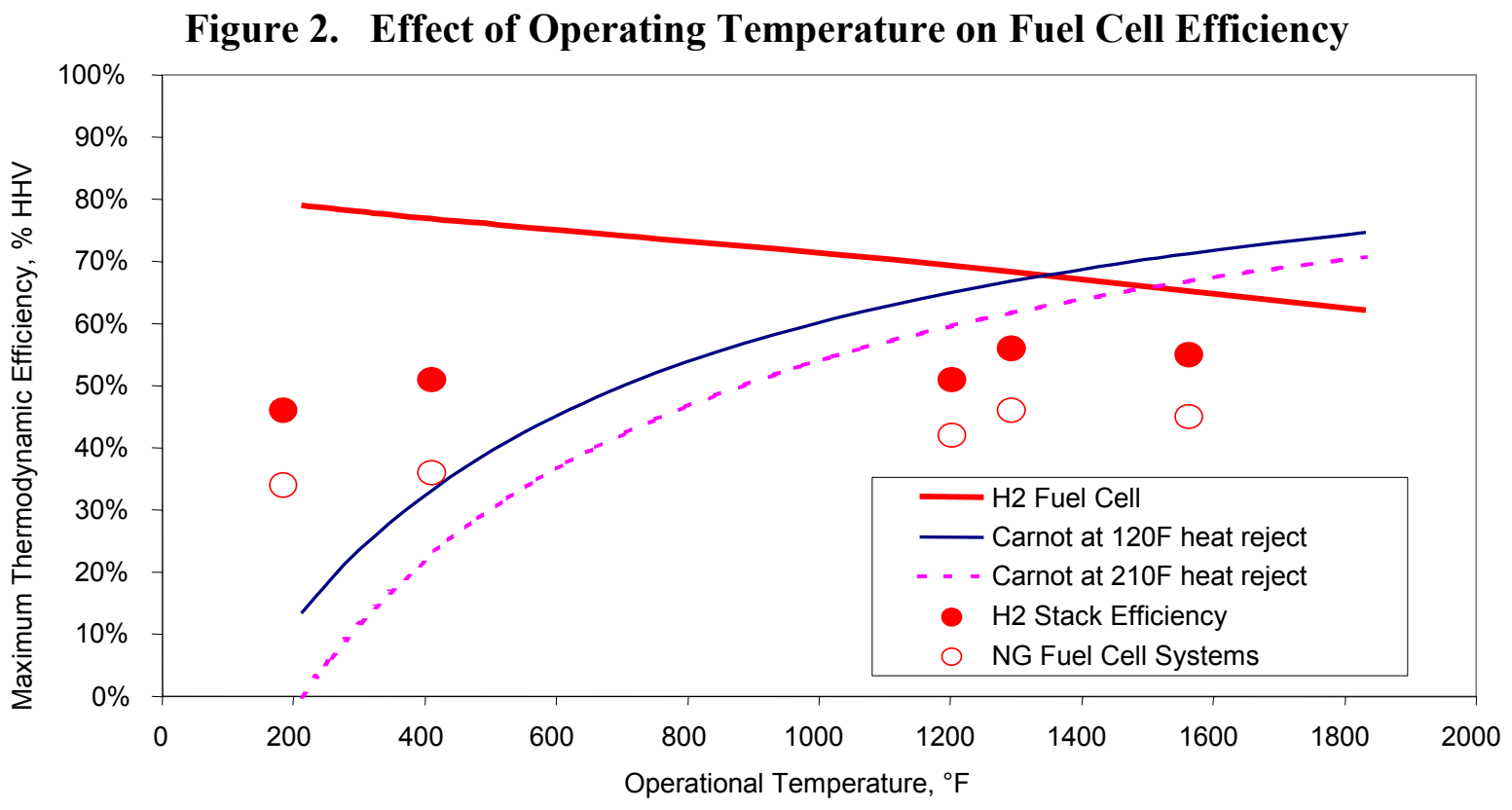

Source: Siemens/Westinghouse Electric Corp.

Figure 2 illustrates this characteristic in comparison to Carnot-cycle efficiency limits with heat rejection at $120^{\circ} \mathrm{F}$ and $210^{\circ} \mathrm{F}^{8}$

\section{Fuel Cell Stacks}

Practical fuel cell systems must deliver voltages higher than 0.55 to 0.80 volts. This is achieved by connecting multiple cells in electrical series into a fuel cell stack. There may be as many as several hundred cells in a stack. The actual number of cells depends on the desired voltage output. The current produced is proportional to the active area of each individual cell.

Typically, cell area can range from $100 \mathrm{~cm}^{2}$ to more than $1 \mathrm{~m}^{2}$ depending on the type of fuel cell and application power requirements.

\section{Fuel Processors}

To operate on natural gas or other fuels, fuel cells require a device that converts the fuel into a hydrogen-rich gas stream. This device is known as a fuel processor or reformer. While adding fuel flexibility to the system, the reformer also adds significant cost and complexity. There are three primary types of reformers: steam reformers, autothermal reformers, and partial oxidation

\footnotetext{
${ }^{8}$ Larminie, James, and Andrew Dicks, Fuel Cell Systems Explained. John Wiley \& Sons, Ltd., West Sussex, England, 2000.
} 
reformers. The fundamental differences are the source of oxygen used to combine with the carbon within the fuel to release the hydrogen and the thermal balance of the chemical process. Steam reformers use steam, partial oxidation units use oxygen gas and autothermal reformers use both steam and oxygen

Steam reforming is extremely endothermic and requires a substantial amount of heat input. Partial oxidation units combust a portion of the fuel (i.e. partially oxidize it), releasing heat in the process. Autothermal reformers balance the amount of steam and oxygen used in order to operate at or near the thermal neutral point and do not generate or consume heat.

When integrated into a fuel cell system that utilizes the exhaust gas from the anode, a typical natural gas reformer can achieve conversion efficiencies in the $75 \%$ to $90 \%$ LHV range, with $83 \%$ to $85 \%$ being an expected level of performance. These efficiencies are defined as the LHV of the hydrogen generated divided by the LHV of the natural gas consumed by the reformer.

Some fuel cells can function as internally steam - reforming fuel cells. Since the reformer is an endothermic catalytic converter - and the fuel cell is an exothermic catalytic oxidizer - the two are combined into one with mutual thermal benefits. More complex than a pure hydrogen fuel cell stack, these types of fuel cells are more difficult to design and operate. While combining two catalytic processes is difficult to arrange and control, internally reforming fuel cells are expected to account for a significant market share as fuel cell systems become more common. Internal reforming eliminates the cost and operational complexity of a separate fuel processor. Internal reforming is only possible in high-temperature fuel cells.

Whenever hydrogen is obtained from a hydrocarbon fuel, there is usually some carbon monoxide (CO) in the hydrogen. Unfortunately, the low-temperature catalysts used in PEMFCs have low tolerance to $\mathrm{CO}$ (commonly called CO-poisoning), which degrades performance. The highertemperature technologies are more tolerant of $\mathrm{CO}$.

Sulfur compounds also poison fuel cell catalysts. Consequently, fuel-processing systems for fuel cells that are designed to operate on infrastructure fuels must include an upstream desulfurizer. The mercaptan odorant used in natural gas is a sulfur compound that typically needs to be removed.

\section{Power-Conditioning Subsystem}

Fuel cells generate low-voltage, direct-current electricity; and individual cells are connected in series to form a cell stack that will deliver more useful voltages - in some cases, 200 to 400 volts. If the system is large enough, cell stacks can be operated in series to double or triple the individual stack voltages. Since the voltage of each individual cell decreases with increasing load or power, fuel cells are considered to be unregulated voltage sources. The powerconditioning subsystem boosts the output voltage to a regulated higher voltage, which becomes the input to an electronic inverter. The inverter then uses a pulse-width modulation technique at high frequencies to synthesize a voltage sine wave, which simulates the alternating current that is typically produced by rotating electromechanical generators. The inverter can vary the phase angle of the voltage and current waveforms to control power-factor characteristics. The 
efficiency of the power-conditioning process is typically $92 \%$ to $96 \%$, and depends on system capacity and input voltage-current characteristics. Power quality is very important to sensitive electronic equipment in premium power applications. Because the alternating current is generated electronically, the output power generally meets power-quality standards - although rotating generating equipment delivers a more-pure sine wave with less harmonic distortion.

\subsection{Types of Fuel Cells}

There are five primary types of fuel cell technologies, each having a different electrolyte and a characteristic operating temperature. Two of these fuel cell types - polymer electrolyte membrane (PEMFC) and phosphoric acid fuel cell (PAFC) - have acidic electrolytes and rely on the transport of $\mathrm{H}^{+}$ions (as shown in Figure 1). They are classified as proton-conducting fuel cells. Two others - the alkaline fuel cell (AFC) and the molten carbonate fuel cell (MCFC) have basic electrolytes that rely on the transport of $\mathrm{OH}^{-}$and $\mathrm{CO}_{3}{ }^{=}$ions, respectively. The fifth type - solid oxide fuel cell (SOFC) - is based on a solid-state ceramic electrolyte, in which oxygen ions $\left(\mathrm{O}^{=}\right)$are the conductive transport ion. The latter three types are classified as anionconducting. Table 1 presents fundamental characteristics for each fuel cell type.

Each fuel cell type has been designed to operate at an optimum temperature, which is a balance between the ionic conductivity and component stability. These temperatures differ significantly among the five basic types, ranging from near-ambient to as high as $1800^{\circ} \mathrm{F}$. The protonconducting fuel cells generate water at the cathode, and the anion-conducting cells generate water at the anode.

Four of the fuel cell types are under active development for distributed generation applications (PEMFC, PAFC, MCFC and SOFC):

PEMFC (Proton Exchange Membrane/Polymer Electrolyte Membrane Fuel Cell)

The PEMFC uses a solid polymer electrolyte and operates at low temperatures (about 150$180^{\circ} \mathrm{F}$ ). During the past 10 years, the PEMFC has received significant media coverage due to the large auto industry investment in the technology. Due to their modularity and potential for simple manufacturing, reformer/PEMFC systems for residential and light commercial applications have also attracted considerable development capital, PEMFC systems (in sizes from $1 \mathrm{~kW}$ to $150 \mathrm{~kW}$ ) are under development by a variety of suppliers (Avista, Ballard, Nuvera, Plug Power, UTC Fuel Cells, and others).

PEMFCs are small and light. Power densities exceeding 1 watt/gram have been achieved. The PEMFC technology has relatively fast start-up times and the best transient response of all fuel cell technologies. PEMFCs have relatively low electric efficiencies (30\% to 40\%) compared to other fuel cell technologies. The low operating temperature also limits the range of potential CHP applications for PEMFCs. This type of fuel cell is highly sensitive to carbon monoxide poisoning, which means that special care must be taken to remove virtually all carbon monoxide from the gas delivered by the fuel-processing unit. 
Table 1. Characteristics of Major Fuel Cell Types

(Projected Electrical Efficiencies are for natural gas-fired fuel cell systems, including fuel processing.)

\begin{tabular}{|l|l|l|l|l|l|}
\hline & PAFC & PEMFC & AFC & MCFC & SOFC \\
\hline $\begin{array}{l}\text { Charge Carrier and } \\
\text { Type of Electrolyte }\end{array}$ & $\begin{array}{l}\mathrm{H}^{+} \text {ions } \\
\left(\mathrm{H}_{3} \mathrm{PO}_{4}-\right. \\
\text { phosphoric } \\
\text { acid - } \\
\text { solutions) }\end{array}$ & $\begin{array}{l}\mathrm{H}^{+} \text {ions (with } \\
\text { anions bound } \\
\text { in polymer } \\
\text { membrane) }\end{array}$ & $\begin{array}{l}\mathrm{OH}^{-} \text {ions } \\
\text { typically, } \\
\text { aqueous } \mathrm{KOH} \\
\text { solution) }\end{array}$ & $\begin{array}{l}\mathrm{CO}_{3}{ }^{-} \text {ions } \\
\text { (typically, } \\
\text { molten } \\
\mathrm{LiKaCO}_{3} \\
\text { eutectics) }\end{array}$ & $\begin{array}{l}\mathrm{O}^{=} \text {ions } \\
\text { (Stabilized } \\
\text { zirconia ceramic } \\
\text { matrix with free } \\
\text { oxide ions) }\end{array}$ \\
\hline Typical construction & $\begin{array}{l}\text { Carbon, } \\
\text { porous } \\
\text { ceramics }\end{array}$ & $\begin{array}{l}\text { Plastic, metal } \\
\text { or carbon }\end{array}$ & Plastic, metal & $\begin{array}{l}\text { High temp } \\
\text { metals, porous } \\
\text { ceramic }\end{array}$ & $\begin{array}{l}\text { Ceramic, high } \\
\text { temp metals }\end{array}$ \\
\hline Internal reforming & No & No & No & $\begin{array}{l}\text { Yes, good } \\
\text { temp match }\end{array}$ & $\begin{array}{l}\text { Yes, good temp } \\
\text { match }\end{array}$ \\
\hline Oxidant & $\begin{array}{l}\text { Air or } \\
\text { Oxygen- } \\
\text { Enriched Air }\end{array}$ & Air or $\mathrm{O}_{2}$ & $\begin{array}{l}\text { Purified Air or } \\
\mathrm{O}_{2}\end{array}$ & Air & Air \\
\hline $\begin{array}{l}\text { Operational } \\
\text { Temperature }\end{array}$ & $\begin{array}{l}370-410^{\circ} \mathrm{F} \\
\left(190-210^{\circ} \mathrm{C}\right)\end{array}$ & $\begin{array}{l}150-180^{\circ} \mathrm{F} \\
\left(65-85^{\circ} \mathrm{C}\right)\end{array}$ & $\begin{array}{l}190-500^{\circ} \mathrm{F} \\
\left(90-260^{\circ} \mathrm{C}\right)\end{array}$ & $\begin{array}{l}1200-1300^{\circ} \mathrm{F} \\
\left(650-700^{\circ} \mathrm{C}\right)\end{array}$ & $\begin{array}{l}1350-1850^{\circ} \mathrm{F} \\
\left(750-1000^{\circ} \mathrm{C}\right)\end{array}$ \\
\hline $\begin{array}{l}\text { Projected Electrical } \\
\text { Efficiency, \% HHV }\end{array}$ & 35 to $45 \%$ & 30 to $40 \%$ & 32 to $40 \%$ & 40 to $50 \%$ & 45 to $55 \%$ \\
\hline $\begin{array}{l}\text { Primary } \\
\text { Contaminant } \\
\text { Sensitivities }\end{array}$ & $\begin{array}{l}\mathrm{CO}>1 \%, \\
\text { Sulfur }\end{array}$ & $\begin{array}{l}\mathrm{CO}, \mathrm{Sulfur}^{\circ} \\
\text { and } \mathrm{NH}_{3}\end{array}$ & $\begin{array}{l}\mathrm{CO}, \mathrm{CO}_{2} \text {, and } \\
\text { Sulfur }\end{array}$ & Sulfur & Sulfur \\
\hline
\end{tabular}

Source: Energy and Environmental Analysis, Inc.

\section{AFC (Alkaline Fuel Cell)}

F.T. Bacon in Cambridge, England, first demonstrated AFCs as viable power units during the 1940s and 1950s. They were later developed for NASA and were used on the Apollo spacecraft. They are still being used on the space shuttles for prime power and to supply drinking water. AFC technology uses alkaline potassium hydroxide as the electrolyte. The primary advantages of AFC technology are high efficiency (electrical efficiencies of the stack above $60 \% \mathrm{HHV}$ ), use of non-precious metal electrodes, and the fact that no other unusual materials are needed. The primary disadvantage is the tendency to absorb carbon dioxide, converting the alkaline electrolyte to an aqueous carbonate electrolyte that is less conductive. In spacecraft applications, which use purified hydrogen and oxygen, contamination by carbon dioxide is not an issue. The attractiveness of AFC for stationary applications has declined substantially because of this disadvantage and recent improvements in competing PEMFC technology.

\section{PAFC (Phosphoric Acid Fuel Cell)}

PAFC uses phosphoric acid as the electrolyte and is generally considered to be the mostestablished fuel cell technology. The first PAFC system was designed and demonstrated in the early 1970s. PAFC systems are capable of fuel-to-electricity efficiencies of $36 \% \mathrm{HHV}$ or greater. A $200 \mathrm{~kW}$ PAFC has been commercially available since 1992 from UTC Fuel Cells (formerly International Fuel Cells/ONSI). More than 250 commercial units are operating in 19 countries on five continents: U.S., Europe, South America, Australia, and Japan. The current $200 \mathrm{~kW}$ product has demonstrated a useful stack life of more than 40,000 hours. The longest 
running units have been in service more than 10 years, and the balance of plant is designed for a 20 -year life. Commercially validated reliabilities are in the $90 \%$ to $95 \%$ range. The success and reliability of the commercial PAFC units has been fundamental in demonstrating the advantages and potential of stationary fuel cell systems.

The major market barrier has been the initial installed cost, which has not yet fallen below the $\$ 4,500$ to $\$ 5,500 / \mathrm{kW}$ range. Because PAFCs rely on high-cost materials such as platinum - and PEMFC systems can provide similar operating characteristics at potentially much lower costs the PAFC is being phased out of commercial production.

\section{MCFC (Molten Carbonate Fuel Cell)}

The MCFC uses alkali metal carbonates ( $\mathrm{Li}, \mathrm{Na}, \mathrm{K}$ ) as the electrolyte and has a developmental history that dates back to the early part of the twentieth century. Due to its operating temperature range of 1100 to $1400^{\circ} \mathrm{F}$, the MCFC holds promise in both CHP and DG applications. This type of fuel cell can internally reform hydrocarbon fuels, can operate at high efficiencies $(50 \% \mathrm{HHV})$, and is relatively tolerant of fuel impurities, especially carbon monoxide. Government/industry RD\&D programs during the 1980s and 1990s resulted in several individual pre-prototype system demonstrations. One developer, FuelCell Energy, is approaching an initial stage of market introduction. The primary technical issue with MCFC technologies is the degradation of cell components due to the corrosive nature of the electrolyte at its high operating temperature.

\section{SOFC (Solid Oxide Fuel Cell)}

The SOFC uses a solid, nonporous metal oxide electrolyte and is generally considered to be less mature in its development than the MCFC and PAFC technologies. Several SOFC units, up to $250 \mathrm{~kW}$ in size and based on a concentric tubular design, have been built and tested by SeimensWestinghouse. In addition, there are a number of companies developing planar SOFC designs (e.g., McDermott Technology, Ceramic Fuel Cells Limited, and Ztek), which are believed to offer the potential for higher power densities and lower costs than the tubular design, but which have yet to achieve the reliability of the tubular design. Despite relative immaturity, the SOFC has several advantages that have attracted development support. High efficiency, stability and reliability, and high internal temperatures distinguish the SOFC from other fuel cell technologies. The SOFC has projected service electrical efficiencies of $45 \%$ to $60 \%$ and higher, for larger hybrid, combined-cycle plants. Efficiencies for smaller SOFC power-only DG units are expected to be around $50 \%$.

The stability and reliability of SOFCs are high due to their all-solid-state ceramic construction. Test cells have operated more than 10 years with acceptable performance. The high internal temperatures of the SOFC are both an asset and a liability. As an asset, high temperatures make internal reforming and high-quality heat recovery possible. As a liability, these high temperatures add to material and mechanical design difficulties, which reduce stack life and increase cost. While SOFC research has been ongoing for 30 years, costs of these stacks are still comparatively high. 


\subsection{Design Characteristics}

The features that have the potential to make fuel cell systems a leading prime mover for CHP and other distributed generation applications include:

Capacity range:

Thermal output:

Availability:

Part-load operation:

Cycling:

High quality power:

Reliability and life:
Fuel cell systems are constructed from individual cells that generate $100 \mathrm{~W}$ to $2 \mathrm{~kW}$ per cell. This allows systems to be configured in a wide range of capacities. Systems under development for DG application range in sizes from $1 \mathrm{~kW}$ to 2 MW. Multiple systems can operate in parallel at a single site to provide higher capacities.

Fuel cells can achieve overall CHP energy efficiencies in the $65 \%$ to $85 \%$ range. Byproduct heat can be used primarily for domestic hot water applications and space heating.

The commercially available $200 \mathrm{~kW}$ PC25 system fleet (250-plus units) has demonstrated close to $90 \%$ availability during more than 6 million operating hours. As the other fuel cell types mature, their reliability should approach or exceed these levels.

Fuel cell stack efficiency improves at lower loads, which results in a total system electrical efficiency that is relatively constant down to one-third to one-quarter of rated capacity. This provides systems with excellent load-following characteristics.

While part-load efficiencies of fuel cells are generally high, MCFC and SOFC fuel cells require long heat-up and cool-down periods, restricting their ability to operate in many cyclic applications.

Electrical output is computer-grade power, and critical power requirements can generally be met without unplanned interruption. This minimizes lost productivity, lost revenues, product loss, or opportunity cost.

Since only auxiliary components have moving parts, the reliability of fuel cells is expected to be high. A few of the initial PC25 systems have achieved operational lives of 70,000 hours, and units have had nonstop continuous runs of 9,500 hours.

The only combustion within a PAFC system is the low-energycontent hydrogen stream exhausted from the stack. This stream is fed to the reformer, and the overall fuel cell system (stack and reformer) can achieve emissions signatures of $<2$ ppmv $\mathrm{CO},<1$ ppmv $\mathrm{NO}_{\mathrm{x}}$, and negligible $\mathrm{SO}_{\mathrm{x}}$ (on $15 \% \mathrm{O}_{2}$, dry basis). 
Efficiency:

Quiet Operation:

Siting and Size:

Fuel Use:
Different types of fuel cells have varied efficiencies. Depending on the type and design of fuel cells, electrical efficiency ranges from $30 \%$ to more than $50 \% \mathrm{HHV}$.

Conversational level (60 dBA @ $30 \mathrm{ft}$.$) , acceptable for indoor$ installation.

Indoor or outdoor installation.

The primary fuel source for the fuel cell is hydrogen, which can be obtained from natural gas, LPG, coal gas, biogas, methanol, and other carbon-containing fuels.

\subsection{Cost and Performance Characteristics}

Fuel cell performance is a function of the type of fuel cell and its capacity. Because the fuel cell system is a series of chemical, electrochemical, and electronic subsystems, the optimization of electrical efficiency and performance characteristics can be a challenging engineering task. The electrical efficiency calculation example provided in the next section illustrates this.

\subsection{System Performance}

Table 2 summarizes performance characteristics of six representative commercially available and developmental natural gas fuel cell systems from the $5 \mathrm{~kW}$ to $2 \mathrm{MW}$ size range. This size range covers the majority of the market applications currently envisioned for fuel cell poweronly and CHP applications, and represents the most likely units to be commercially introduced within the next five years. Of the systems included in Table 2, only the PAFC product, which was introduced in 1992, is considered fully commercially available at this time. The other systems are in various phases of prototype, precommercial, or early commercial demonstration. Cost and performance estimates for these systems are based on initial market-entry targets (manufacturers' target introductory price estimates) rather than actual purchase prices and documented field performance. The costs are based on CHP configurations because the majority of systems under development integrate heat-recovery capability to supply thermal requirements at the site. Heat can be recovered from cell stack cooling loops, the fuel-processing subsystem, and various exhaust streams. The PAFC extracts heat from both the reformer and cathode exhaust streams as part of a water-recovery process. The resulting condensate is used to replenish cell stack cooling loop water that has been converted to steam for the fuel-reforming process. The capital cost estimate for the PAFC system represents published costs from the manufacturer for lots of three or more units. Since the other systems are just emerging from their demonstration phases, pricing and costing information are much less certain, and estimates should be considered to be within a range of plus or minus $25 \%$.

Heat rates and efficiencies shown were taken from manufacturers' specifications and industry publications, or they are based on the best available data for developing technologies. Available thermal energy was based on manufacturer/developer specifications and/or calculated from estimated overall efficiency for these systems. CHP thermal recovery estimates are based on 
producing low-quality heat for domestic hot water, process, or space heating. This feature is generally acceptable for commercial/institutional applications, where it is more common to have hot water thermal loads.

The data in the table show that electrical efficiency increases, as the operating temperature of the fuel cell increases. Also illustrated is an efficiency increase as system size becomes larger. As electrical efficiency increases, the absolute quantity of thermal energy available to produce useful thermal energy decreases per unit of power output; and the ratio of power to heat for the CHP system generally increases. The ratio of power to heat affects project economics and may affect the decisions that customers make in terms of CHP acceptance, sizing, and the desirability of selling power. 
Table 2. Fuel Cell Systems - Typical Performance Parameters (2003)

\begin{tabular}{|c|c|c|c|c|c|c|}
\hline Cost and Performance Characteristics ${ }^{y}$ & System 1 & System 2 & System 3 & System 4 & System 5 & System 6 \\
\hline Fuel Cell Type & PAFC & PEMFC & PEMFC & MCFC & MCFC & SOFC \\
\hline Typical System Size (kW) & 200 & $5-10$ & $150-250$ & 250 & 2000 & $100-250$ \\
\hline \multicolumn{7}{|l|}{ Fuel Cell Characteristics } \\
\hline Nominal Electricity Capacity $(\mathrm{kW})^{10}$ & 200 & 10 & 200 & 250 & 2000 & 100 \\
\hline Projected Commercial Date & 1992 & $2003-2005$ & $2005+$ & $2003-2005$ & $2005+$ & $2005+$ \\
\hline Operating Temperature $\left({ }^{\circ} \mathrm{F}\right)$ & 400 & 150 & 150 & 1200 & 1200 & 1750 \\
\hline Electrical Efficiency (\%), HHV ${ }^{11}$ & 36 & 30 & 35 & 43 & 46 & 45 \\
\hline Electric Heat Rate (Btu/kWh), HHV ${ }^{12}$ & 9,480 & 11,370 & 9,750 & 7,930 & 7,420 & 7,580 \\
\hline Fuel Input (MMBtu/hr) & 1.90 & 0.11 & 1.95 & 1.98 & 14.80 & 0.80 \\
\hline Package Cost $(2003 \$ / \mathrm{kW})^{13}$ & 4,500 & 4,700 & 3,120 & 4,350 & 2,830 & 2,850 \\
\hline Total Installed Cost $(2003 \$ / \mathrm{kW})^{14}$ & 5,200 & 5,500 & 3,800 & 5,000 & 3,250 & 3,620 \\
\hline O\&M Costs $(\$ / \mathrm{kW})^{15}$ & 0.029 & 0.033 & 0.023 & 0.043 & 0.033 & 0.024 \\
\hline \multicolumn{7}{|l|}{ CHP Characteristics ${ }^{16}$} \\
\hline Heat Avail. $>160^{\circ} \mathrm{F}(\mathrm{MMBtu} / \mathrm{hr})$ & 0.34 & 0.00 & 0.00 & 0.22 & 1.89 & 0.10 \\
\hline Heat Avail. $<160^{\circ} \mathrm{F}(\mathrm{MMBtu} / \mathrm{hr})$ & 0.34 & 0.04 & 0.72 & 0.22 & 1.67 & 0.09 \\
\hline Heat Output (MMBtu/hr) & 0.68 & 0.04 & 0.72 & 0.44 & 3.56 & 0.19 \\
\hline Heat Output (kW equivalent) & 200 & 13 & 211 & 128 & 1043 & 56 \\
\hline Total CHP Efficiency (\%), HHV ${ }^{17}$ & 72 & 69 & 72 & 65 & 70 & 70 \\
\hline Power/Heat Ratio ${ }^{18}$ & 1.0 & 0.79 & 0.95 & 1.95 & 1.92 & 1.79 \\
\hline Net Heat Rate $(B t u / k W h)^{19}$ & 5,215 & 5,825 & 5,250 & 5,750 & 5,200 & 5,210 \\
\hline
\end{tabular}

Source: Energy and Environmental Analysis, Inc.

${ }^{9}$ Data are representative typical values for developmental systems based on available information from fuel cell system developers. Only the PAFC data represent products with significant commercial operating experience. Developers include but are not limited to UTC Fuel Cells, Toshiba, Ballard Power, Plug Power, FuelCell Energy, Siemens-Westinghouse, Hydrogenics, Honeywell, Fuji, IHI, Global Thermal, Mitsubishi Heavy Industries, and Ztek.

${ }^{10}$ Nominal electric capacity of initial commercial units - basis of technology characterization estimates.

${ }^{11}$ Electrical efficiencies are net of parasitic and power conversion losses.

${ }^{12}$ All equipment manufacturers quote heat rates in terms of the lower heating value (LHV) of the fuel. Table 2 provides heat rates based on HHV because the energy content of fuels is typically measured on a higher heating value (HHV) basis. In addition, electric utilities measure power plant heat rates in terms of HHV. For natural gas, the average HHV is $1,030 \mathrm{Btu} / \mathrm{scf}$ and the LHV is $930 \mathrm{Btu} / \mathrm{scf}-$ or about a $10 \%$ difference.

${ }^{13}$ Packaged Cost includes estimates of typical costs for a CHP compatible system with grid interconnection functionality built into the power conditioning subsystem.

${ }^{14}$ Total Installed Cost includes estimates for packaged cost plus electrical isolation equipment, hot water CHP interconnections, site labor and preparation, construction management, engineering, contingency, and interest during construction. See Table 3.

${ }^{15} \mathrm{O} \& \mathrm{M}$ costs are estimated based on service contract nominal rate, consumables, fixed costs, and sinking fund for stack replacement at end of life. See Table 4.

${ }^{16} \mathrm{CHP}$ characteristics based on utilizing all available thermal energy from the fuel cell system; the quality of thermal energy available varies by technology.

${ }^{17}$ Total Efficiency $=($ net electric power generated + net heat produced for thermal needs)/total system fuel input energy.

${ }^{18}$ Power/Heat Ratio $=$ CHP electrical power output $($ in Btu equivalent $) /$ useful heat output $(B t u)$.

${ }^{19}$ Net Heat Rate $=$ (Total fuel energy input to the CHP system - the fuel energy that would normally be used to generate the same amount of thermal output as the CHP system thermal output, assuming an efficiency of $80 \%) / \mathrm{CHP}$ electric output $(\mathrm{kW})$. 


\section{Electrical Efficiency}

As with all power-generation technologies, the electrical efficiency is the ratio of the power generated to the heating value of the fuel consumed. Because the fuel cell system has several subsystems in series, the electrical efficiency of the DG unit is the mathematical product of the efficiencies of the individual subsystems. The concept of stack subsystem electrical efficiency was described earlier. The electrical efficiency of a complete fuel cell system is calculated as follows:

$$
\begin{aligned}
& \text { ElecEff }=\left(\text { FPS Eff } * \mathrm{H}_{2} \text { Utilization } * \text { Stack Eff } * \text { PC Eff }\right) *(\text { HHV/LHV ratio of the fuel }) \\
& \begin{aligned}
& \text { Where: FPS Eff } \text { Fuel Processing Subsystem Efficiency, LHV } \\
&=\left(\text { LHV of } \mathrm{H}_{2} \text { Generated/LHV of Fuel Consumed }\right) \\
& \mathrm{H}_{2} \text { Utilization }=\% \text { of } \mathrm{H}_{2} \text { actually consumed in the stack } \\
& \text { Stack Eff }=(\text { Operating Voltage/Energy Potential } \sim 1.23 \text { volts }) \\
& \text { PC Eff }=\text { AC power delivered/(DC power generated }) \\
&\text { (auxiliary loads are assumed DC loads here })
\end{aligned}
\end{aligned}
$$

\footnotetext{
For example: $\mathrm{PAFC}=(84 \% \mathrm{FPS}) *(83 \%$ util $) *(0.75 \mathrm{~V} / 1.23 \mathrm{~V}) *(95 \% \mathrm{PC}) *(0.9 \mathrm{HHV} / \mathrm{LHV})$ $=36 \%$ electrical efficiency HHV
}

As the operating temperature of the fuel cell subsystem increases, the electrical efficiency of the system tends to increase. Although the maximum thermodynamic efficiency of the fuel cell decreases with increasing temperature (as shown in Figure 2), improvements in reformer subsystem integration and increases in reactant activity balance out to provide the system-level increase. Advanced high-temperature MCFC and SOFC systems are projected to achieve electrical efficiencies in the range of $50 \%$ to $55 \% \mathrm{HHV}$, while hybrid combined fuel cell-heat engine systems are calculated to achieve efficiencies above $60 \%$.

\section{Part-Load Performance}

In power-only and CHP applications, fuel cell systems are expected to follow either the electric or thermal load of the applications to maximize energy efficiency and economics. Figure 3 shows the part-load efficiency curve for a market-entry PAFC fuel cell compared to a typical lean burn natural gas engine. As shown in the figure, fuel cell efficiency remains relatively constant over an operating range of $50 \%$ to $100 \%$ load; the fuel cell efficiency at $40 \%$ load is within 2 percentage points of its full load efficiency. As the load decreases further, the curve becomes somewhat steeper, as inefficiencies in air blowers and the fuel processor begin to override the stack efficiency improvement.

\section{Fuel Cell Degradation}

As with any sophisticated technology, fuel cells rely on a fine balance of parameters that support efficient operation. With no moving parts in the active electric generating component, fuel cells offer the promise of long-term operation with high durability and low maintenance. However, a large concern with fuel cells is cell performance degradation, which is reflected in the slow decrease in operating voltage over time. Typically, fuel cell degradation rates are measured in $\mathrm{mV} / 1000$ hours of operation, and values of $1-2 \mathrm{mV} / 1000 \mathrm{hrs}$ (approximately $10 \%$ after five years 
of continuous operation) are typical. To maintain constant power output, this drop in voltage is compensated for by increasing the current flow through each individual cell; but increasing the current flow causes a decrease in efficiency. Alternately, the voltage and efficiency can be maintained by decreasing the current flow, but this decreases power production. Typically, fuel cell systems are designed with extra cells to compensate for this degradation, so they can maintain both power and efficiency specifications until a defined point in time. Fuel cell stack life is the point when the stacks are replaced or refurbished to recover initial power and efficiency performance. Stack replacement is truly an economic decision. If it is more economic to avoid the capital investment, operation can be continued at lower power or efficiency. One or more of the following degradation mechanisms affects each fuel cell type:

1. Pore structure changes. One of the most critical microscopic features of a fuel cell electrode is the three-phase interface between the process gas (oxygen or hydrogen), the electrolyte, and the electrically conductive material that conducts the electrons within the electrode. The position of the interface within the electrodes is finely balanced for optimal cell performance. The interface position is controlled in one of several different ways, depending on the type of fuel cell. For example, in liquid electrolyte fuel cells, such PAFCs, a hydrophobic material (typically a Teflon derivative) is added to the electrode structure to create a balance between the liquid contact and gas contact at the active catalyst sites. In solid electrolyte fuel cells, such as the SOFC and PEM, gas pore formers are added to the structure to optimize this three-phase balance. Over time, changes in the physical structure change the balance and degrade cell performance.

2. Catalyst poisoning. Contaminants in the process gases, such as sulfur or carbon monoxide, can degrade performance by blocking the active catalyst sites.

3. Catalyst sintering. Although catalyst sites are typically viewed as fixed, finely divided active surfaces where reactions occur, the fine catalyst particles have some mobility - and, with time and temperature, they tend to migrate together forming larger catalyst particles with less-active area. The decrease in active area causes lower reaction rates and poorer performance.

4. Increased electrical resistance. Increased electrical resistance in a fuel cell degrades the cell's performance. One prime example of this is the increase in surface or interface resistance that occurs in MCFC when the metal separator plates corrode, creating a less conductive oxide compound. Since the electrons involved in the reactions within the electrode must pass through this interface into the bipolar plate and into the next cell in the stack, increased resistance decreases the effective operating voltage of the stack.

5. Electrolyte degradation. Blockage or chemical changes in the electrolyte cause it to have lower ionic conductivity, leading to increased voltage losses in the electrolyte. One example is the leaching of acid components from PEM membranes due to breakage of the chemical bonds that hold them to the polymer backbone. In addition to decreased ionic conductivity, the electrical conductivity of the electrolyte membrane may increase, leading to further power losses through partial internal short-circuiting of the cell. 
Figure 3. Part-Load Efficiency Performance

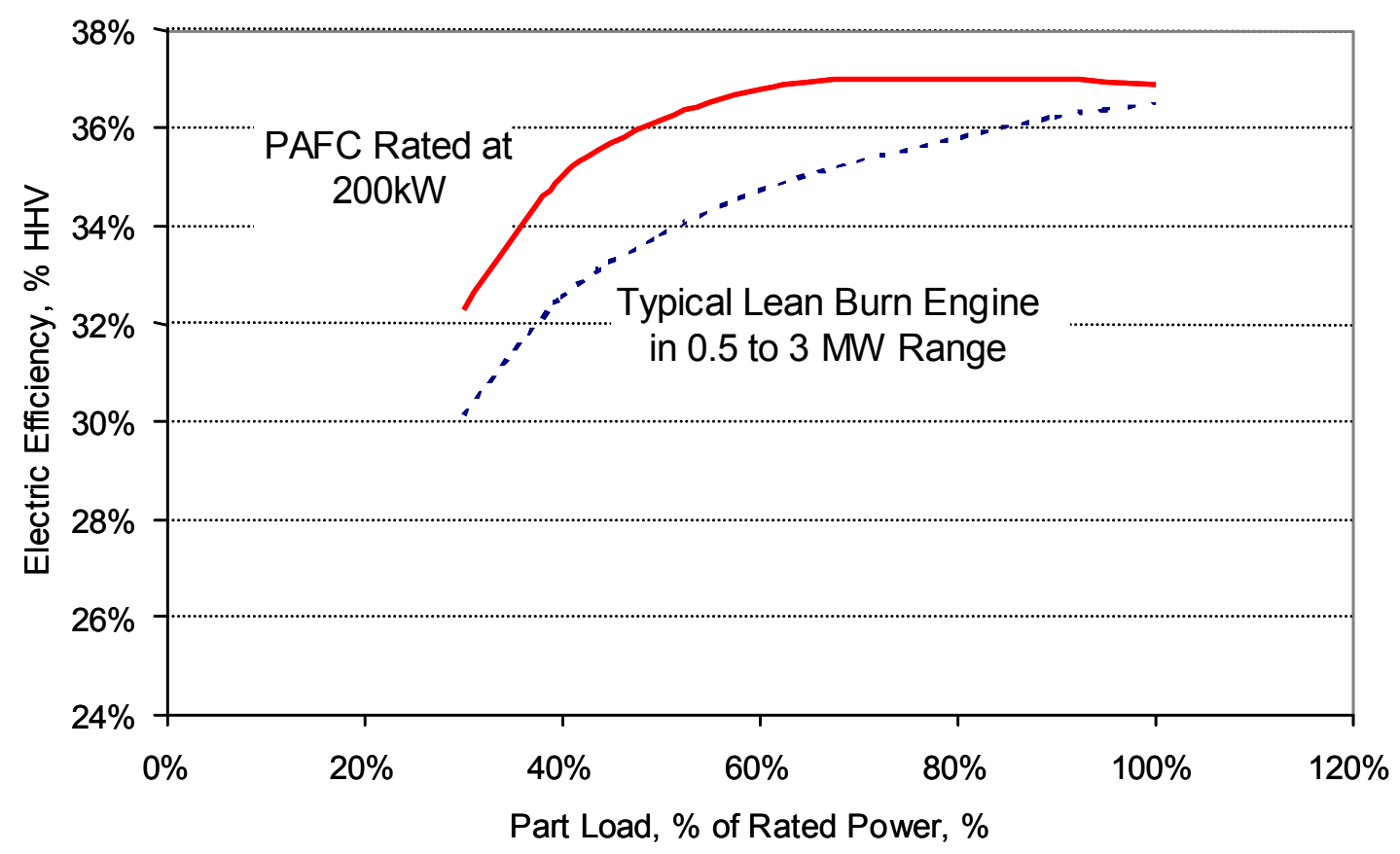

Source: Gas Research Institute, Caterpillar, and EEA.

\subsection{Combined Heat and Power Performance}

Heat recovery will improve the economics of any distributed generation technology, including fuel cells. However, the economics of fuel cells depends less on heat recovery than the economics of lower efficiency prime movers, such as microturbines and small reciprocating engines. There are four primary potential sources of usable byproduct heat from a fuel cell system: exhaust gas, including water condensation, stack cooling, anode-off gases, and reformer heat. Heat can generally be recovered in the form of hot water or low-pressure steam but the amount and quality of heat is very dependent on the fuel cell operating temperature. For example, the PEMFC, which operates at temperatures below $180^{\circ} \mathrm{F}$, has only low-quality heat available for recovery.

Generally, $25 \%$ of the inlet fuel energy is recoverable as higher quality (higher temperature) heat from the stack and reformer subsystems, and another $25 \%$ is contained in the cathode exhaust gases that include the latent heat of the product water generated in the fuel cell. The most common use of this heat is to generate hot water or low-pressure steam $(<30 \mathrm{psig})$ for space heating, process needs, or domestic hot water.

The PAFC system currently achieves $36 \%$ electrical efficiency and $72 \%$ overall CHP efficiency; it has a $36 \%$ thermal efficiency and a power-to-heat ratio of one. Of the available heat, $25 \%$ to $45 \%$ is recovered from the stack-cooling loop, which operates at approximately $400^{\circ} \mathrm{F}$ and can deliver low- to medium-pressure steam. The balance of heat is derived from the cathode exhaust gas-cooling loop, which serves two functions. The primary function is condensation of product water, thus rendering the system water self-sufficient; and the secondary function is the recovery 
of byproduct heat. The byproduct heat is recoverable as hot water, suitable for space heating or water heating. All of the available anode exhaust-gas heat and reformer heat is used internally to maximize system efficiency.

SOFCs and MCFCs can generate medium-pressure steam (up to about $150 \mathrm{psig}$ ) from the fuel cell's high-temperature cathode exhaust gas, but the primary use of the exhaust-gas heat is in recuperative heat exchange with the inlet process gases. Like engine and turbine systems, fuel cell exhaust gas often can be used directly in drying processes.

\subsection{Performance and Efficiency Enhancements}

\section{Effects of Ambient Conditions on Performance}

Fuel cells are generally rated at ISO conditions of $77^{\circ} \mathrm{F}$ and 0.987 atmospheres ( 1 bar) pressure. Fuel cell system performance - both output and efficiency - can degrade as ambient temperature or site elevation increases. This degradation in performance is related to ancillary equipment performance, primarily the air-handling blowers or compressors, not the fuel cell stack itself. Performance degradations will be greater for pressurized systems operating with turbo-chargers or small air compressors as their primary air supply components.

\section{Effects of Pressure}

Air is fed to the cathode side of the fuel cell stack to provide the oxygen needed for the powergeneration process. Typically, $50 \%$ to $100 \%$ more air is passed through the cathode than is required for the fuel cell reactions. The fuel cell can be operated at near-ambient pressure, or at elevated pressures to enhance stack performance. Increasing the pressure, and therefore the partial pressure of the reactants, increases stack performance by reducing the electrode overpotentials associated with moving the reactants into the electrodes where the catalytic reaction occurs. Higher pressure also improves the performance of the catalyst. These improvements appear to optimize at approximately three atmospheres. However, compressor performance and energy requirements also affect the optimum operating conditions, requiring trade-offs between cell stack performance and operating pressure.

\subsection{Capital Cost}

This section provides estimates for the installed cost of fuel cell systems designed for DG applications. Only CHP configurations are presented, because the majority of systems under development integrate heat-recovery capability, both to meet thermal requirements at the site and to condense water produced in the fuel cell to feed the fuel-processing unit. Capital costs (equipment and installation) are estimated in Table 3 for the six typical fuel cell systems presented in Table 1. Since most of the systems in Table 3 are still in the development phase, estimates are "typical" budgetary price levels based on development targets for commercial entry units and manufacturer commercialization strategies. It should be noted that installed costs can vary significantly, depending on the scope of the plant equipment, geographical area, 
competitive market conditions, special site requirements, prevailing labor rates, and whether the system is a new or retrofit application.

Based on publicly available information and internal analysis, each of five major component groups, with approximately 20 major components, was used to define the individual fuel cell systems and to develop total package cost estimates. Cost and pricing information was estimated in constant 2003 dollars and totaled across major component groups to determine the estimated packaged cost of each system. This process allowed for uniform estimates for similar components of similar capacity such as the power electronics, and adjustments for components such as the cell stack and reformer subsystems due to technology differences and product requirements

The five major subsystems were:

- Stack subsystem - consisting of the fuel cell stacks, feed gas manifolds, and power takeoffs

- Fuel processing subsystem - consisting of fuel management controls, reformer, steam generators, shift reactors, sulfur absorbent beds, and ancillary components

- Power and electronic subsystem - consisting of a solid-state boost regulator, DC to AC inverters, grid interconnect switching, load management and distribution hardware, and inverter controller and overall supervisory controller

- Thermal management subsystem - consisting of the stack cooling system, heat recovery, and condensing heat exchangers

- Ancillary subsystems - consisting of the process air supply blowers, water treatment system, safety controls and monitoring, cabinet ventilation fans, and other miscellaneous components.

In general, the stack subsystem can represent from $25 \%$ to $40 \%$ of equipment cost, the fuel processing subsystem from $25 \%$ to $30 \%$, the power and electronics subsystem from $10 \%$ to $20 \%$, the thermal management subsystem from $10 \%$ to $20 \%$, and ancillary subsystems from $5 \%$ to $15 \%$. One of the major issues with fuel cell systems is process complexities and the cost of equipment to maintain expanded features and characteristics.

The cost of the basic fuel cell package (described above) plus the costs for added systems needed for the particular application comprise the total equipment cost. The total plant cost consists of total equipment cost plus installation labor and materials (including site work), engineering, project management (including licensing, insurance, commissioning and startup), and contingency. The installation costs of fuel cell systems are assumed to be similar to those of similar-sized engine-based equipment. The range of $\$ 400$ to $\$ 800 / \mathrm{kW}$ used in Table 3 reflects this relationship but includes additional costs due to increased risk and lack of experience associated with new and unique technology. No additional costs were applied for emission controls technologies or permitting delays. 


\section{Table 3. Estimated Capital Cost for Typical Fuel Cell System in Grid-Interconnected CHP Applications (2003 \$/kW)*}

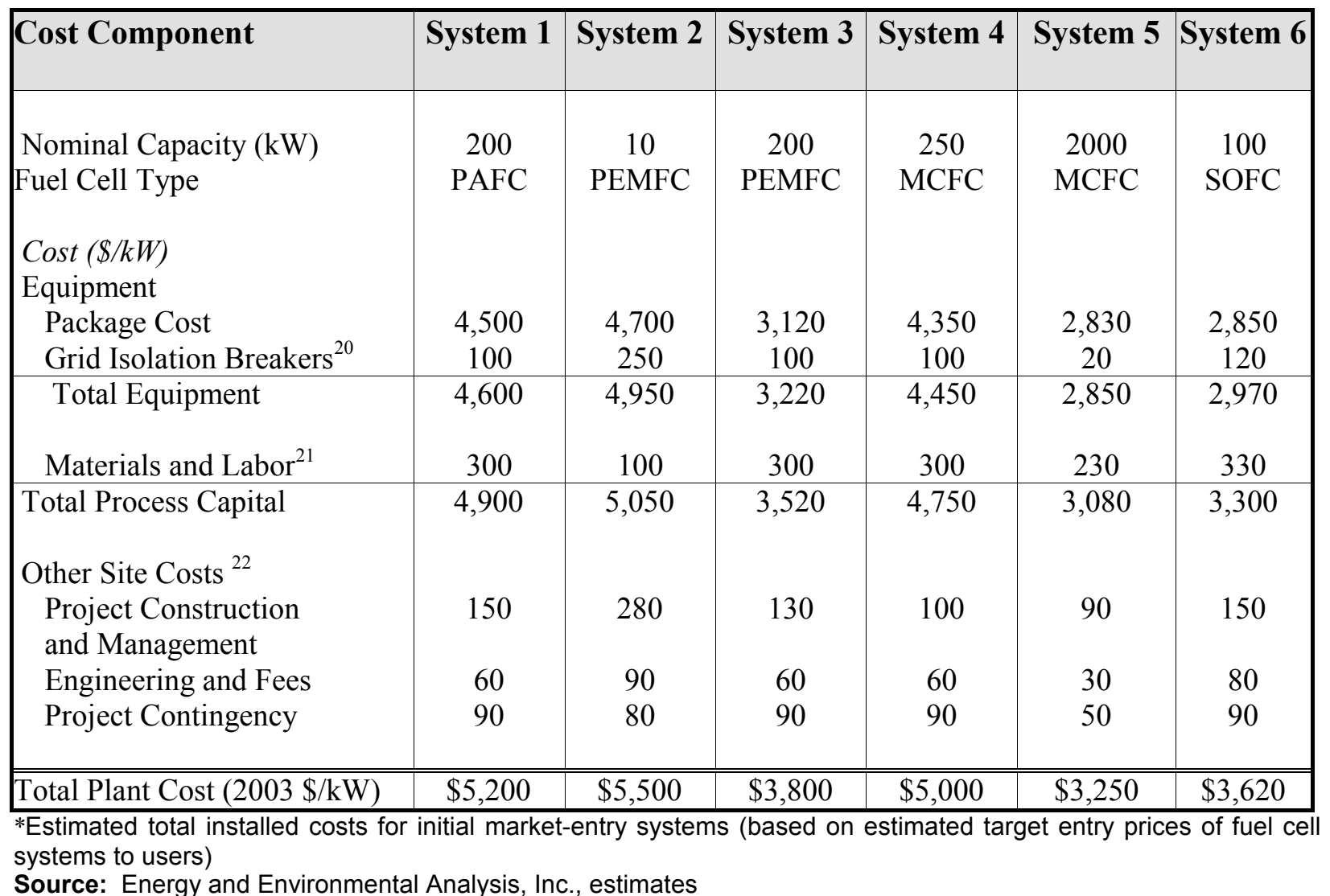

\subsection{Maintenance}

Maintenance costs for fuel cell systems will vary with type of fuel cell, size, and maturity of the equipment. Some of the typical costs that are included in Table 4 are:

- Maintenance labor

- Scheduled maintenance, including replacement of water-treatment beds and filter cleaning (no shutdown required).

- Annual maintenance, including pump overhaul, condenser cleaning, igniter and flame recognition replacement, and air and water filter replacement or cleaning.

\footnotetext{
${ }^{20}$ Only grid isolation breakers are included because the functionality of grid interconnection and isolation has been included with the power conditioning subsystem in the package cost. For example, $\$ 100 / \mathrm{kW}$ was included for System 1 and System 3 at $200 \mathrm{~kW}$ capacity.

${ }^{21}$ Materials and labor estimates were based on typical reciprocating engine CHP systems for units between 100 and 2,000 kW. The 5-10 kW system was estimated based on appliance-type residential installations.

${ }^{22}$ Other site-related cost estimates were based on data extrapolated from typical engine CHP systems for units between 100 and $2,000 \mathrm{~kW}$.
} 
- Consumables, including mixed resin and activated charcoal for water treatment, nitrogen for start-up and shutdown purging, and miscellaneous filters.

- Major overhauls, including shift catalyst replacement (three to five years), reformer catalyst replacement (five years), and stack replacement (four to eight years) ${ }^{23}$

Maintenance can either be performed by in-house personnel or contracted out to manufacturers, distributors, or dealers under service contracts. Details of full maintenance contracts (covering all recommended service) and costing are not generally available, but are estimated at 0.7 to 2.0 cents $/ \mathrm{kWh}$, excluding the stack replacement cost sinking fund. Maintenance for initial commercial fuel cells has included remote monitoring of system performance and conditions and an allowance for preventive maintenance. Recommended service is comprised of routine short interval inspections/adjustments and periodic replacement of filters (projected at intervals of 2,000 to 4,000 hours).

Maintenance costs presented in Table $\mathbf{4}$ are based on projected service contracts consisting of routine inspections and scheduled overhauls of the fuel cell system and are prorated based on comparable engine-generator service contracts. Stack life and replacement costs are based on developers' estimates for initial units. Overall maintenance costs are based on 8,000 annual operating hours expressed in terms of annual electricity generation.

Table 4. Typical Fuel Cell Systems (Non-fuel) O\&M Costs (2003)

\begin{tabular}{|c|c|c|c|c|c|c|}
\hline O\&M Cost Analysis $(2003 \$)^{24}$ & System 1 & System 2 & System 3 & System 4 & System 5 & System 6 \\
\hline Capacity (kW) & 200 & $5-10$ & $150-250$ & 250 & 2000 & $100-250$ \\
\hline Fuel Cell Type & PAFC & PEMFC & PEMFC & $\mathrm{MCFC}$ & $\mathrm{MCFC}$ & SOFC \\
\hline Variable Service Contract $(\$ / \mathrm{kWh})$ & 0.0087 & 0.0121 & 0.0087 & 0.0072 & 0.0054 & 0.0102 \\
\hline Variable Consumables $(\$ / \mathrm{kWh})$ & 0.0002 & 0.0002 & 0.0002 & 0.0002 & 0.0002 & 0.0002 \\
\hline Fixed $(\$ / k W-y r)$ & 6.5 & 18.0 & 6.5 & 5.0 & 2.1 & 10.0 \\
\hline Fixed (\$/kWh@8,000 hrs/yr) & 0.0008 & 0.0023 & 0.0008 & 0.0006 & 0.0003 & 0.0013 \\
\hline Stack Fund $(\$ / \mathrm{kWh})^{25}$ & 0.0193 & 0.0188 & 0.0132 & 0.0350 & 0.0275 & 0.0125 \\
\hline Stack Life ${ }^{26}(\mathrm{yrs})$ & 5 & 4 & 4 & 4 & 4 & 8 \\
\hline Recovery Factor (\%) & 30 & 50 & 35 & 30 & 20 & 20 \\
\hline Total O\&M cost $(2003 \$ / \mathrm{kWh})$ & 0.029 & 0.033 & 0.023 & 0.043 & 0.033 & 0.024 \\
\hline
\end{tabular}

Source: Energy and Environmental Analysis cost estimates for initial market-entry systems.

\footnotetext{
${ }^{23}$ These component replacement estimates are not demonstrated values, but are estimates for mature fuel cell products

${ }^{24}$ Fixed costs are based on an interpolation of reciprocating engine manufacturers' estimates and applied to fuel cell system. The variable component of the O\&M cost represents the inspections and minor procedures that are normally conducted by the original equipment manufacturer through a service agreement, and have been estimated based on $60 \%$ of reciprocating engine service contracts. Major overhaul procedures primarily representing stack replacements have been handled as a separate item.

${ }^{25}$ Stack replacement costs have been estimated $=$ (stack original cost*(1-recovery factor) $) /($ stack life $* 8,000 \mathrm{hrs} / \mathrm{yr})$. Stack life was estimated based on type of fuel cell. Recovery factor was based on catalyst recovery, metal scrap value and non-repeat hardware value at end of life. All estimates are considered first-cut projections and have an uncertainty of $+/$ - one year or $+/-15 \%$. The small PEMFC recovery factor was higher due to its higher non-repeat component cost.

${ }^{26}$ Except for PAFC, stack life estimates based on development and testing targets.
} 


\subsection{Fuels}

Because the primary fuel source for fuel cells is hydrogen produced from hydrocarbon fuels, fuel cell systems can be designed to operate on a variety of alternative gaseous fuels including:

- Liquefied petroleum gas (LPG) - propane and butane mixtures

- Sour gas - unprocessed natural gas as it comes directly from the gas well

- Biogas - any of the combustible gases produced from biological degradation of organic wastes (such as landfill gas, sewage digester gas, and animal waste digester gas), or from direct gasification of biomass

- Industrial waste gases - flare gases and process off-gases from refineries, chemical plants, and steel mills

- Manufactured gases - typically low- and medium-Btu gas produced by gasification or pyrolysis processes.

Factors that impact the operation of a fuel cell system with alternative gaseous fuels include:

- Heating value - Since fuel is reformed by the fuel cell's fuel-processing subsystem, the lower-energy content fuels will simply result in a less-concentrated, hydrogen-rich gas stream feeding the anode. This will cause some loss in stack performance, which can affect stack efficiency and stack capacity. Increased pressure drop through various flow passages also can decrease the fine balance developed in fully integrated systems.

- Contaminants are the major concern when operating on alternative gaseous fuels. If any additional sulfur and other components (e.g., chlorides) can be removed prior to entering the fuel-processing catalyst, there should be no performance or life impact. If not, the contaminants can shorten the life of the fuel processor catalyst and the fuel cell stack.

\subsection{Availability and Life}

Although fuel cell systems are generally perceived as low-maintenance devices with potential for high availability, their performance is currently unproven due to technical immaturity and market-entry status. Data have been developed on the availability of the initial fleet of more than 250 commercial PAFC fuel cell units. In a recent 12-month period, the fleet of units in North America achieved $95.4 \%$ availability, with $92.6 \%$ during the last 30 days of the period. In premium power applications, where some redundancy is provided, $100 \%$ customer power availability and $96.3 \%$ fleet availability has been reported. ${ }^{27}$ This performance is a preliminary indicator that fuel cells can provide high levels of availability, even in high load factor applications. In general, unit availabilities of $75 \%$ to $80 \%$ can be expected in the initial market-

${ }^{27}$ According to manufacturer United Technology Corporation (http://www.UTCfuelcells.com/, 3/28/02). 
entry systems. Availabilities of more than $90 \%$ are projected for mature market products. Estimated equipment life is projected at 10 years.

\subsection{Emission Characteristics}

Because the power-generation process in fuel cell systems is electrochemical, no emissions from combustion are produced from the power generation itself. The fuel-processing subsystem is the primary source of the limited combustion emissions generated in fuel cell systems.

\subsection{Control Options}

For PAFCs, the anode-off gas, which typically consists of $8 \%$ to $15 \%$ hydrogen, is burned in a catalytic or surface burner element to heat the reformer. The temperature of this very lean combustion can be maintained at less than $1800^{\circ} \mathrm{F}$, which limits the formation of oxides of nitrogen $\left(\mathrm{NO}_{\mathrm{x}}\right)$ but is sufficiently high to ensure oxidation of carbon monoxide $(\mathrm{CO})$ and volatile organic compounds (VOCs - unburned, nonmethane hydrocarbons). Other pollutants, such as oxides of sulfur $\left(\mathrm{SO}_{\mathrm{x}}\right)$, are not emitted because sulfur is typically removed in an adsorption bed before the fuel is processed.

Table 5. Fuel Cell Emission Characteristics (without Additional Controls)*

\begin{tabular}{|c|c|c|c|c|c|c|}
\hline Emissions Characteristics ${ }^{28}$ & $\begin{array}{c}\text { System } \\
1\end{array}$ & $\begin{array}{c}\text { System } \\
2\end{array}$ & $\begin{array}{c}\text { System } \\
3\end{array}$ & $\begin{array}{c}\text { System } \\
4\end{array}$ & $\begin{array}{c}\text { System } \\
5\end{array}$ & $\begin{array}{c}\text { System } \\
6\end{array}$ \\
\hline Fuel Cell Type & PAFC & PEMFC & PEMFC & MCFC & MCFC & SOFC \\
\hline Nominal Capacity (kW) & 200 & 10 & 200 & 250 & 2000 & 100 \\
\hline Electrical Efficiency (\%), HHV & 36 & 30 & 35 & 43 & 46 & 45 \\
\hline \multicolumn{7}{|l|}{ Emissions $^{29}$} \\
\hline $\mathrm{NO}_{\mathrm{x}},\left(\mathrm{ppmv} @ 15 \% \mathrm{O}_{2}\right)$ & 1.0 & $<2.0$ & $<2.0$ & 2.0 & 2.0 & 2.0 \\
\hline $\mathrm{NO}_{\mathrm{x}},(\mathrm{lb} / \mathrm{MWh})$ & 0.04 & 0.1 & 0.1 & 0.06 & 0.05 & 0.05 \\
\hline $\mathrm{CO},\left(\mathrm{ppmv} @ 15 \% \mathrm{O}_{2}\right)$ & 2.0 & $<3.0$ & $<3.0$ & 2.0 & 2.0 & 2.0 \\
\hline $\mathrm{CO}, \quad(\mathrm{lb} / \mathrm{MWh})$ & 0.05 & 0.07 & 0.07 & 0.04 & 0.04 & 0.04 \\
\hline VOC, (ppmv@15\% O & 0.7 & 0.4 & 0.4 & 0.5 & 1.0 & 1.0 \\
\hline VOC, $(\mathrm{lb} / \mathrm{MWh})$ & 0.01 & 0.01 & 0.01 & 0.01 & 0.01 & 0.01 \\
\hline $\mathrm{CO}_{2}, \quad(\mathrm{lb} / \mathrm{MWh})$ & 1,135 & 1,360 & 1,170 & 950 & 890 & 910 \\
\hline Carbon, (lb/MWh) & 310 & 370 & 315 & 260 & 240 & 245 \\
\hline
\end{tabular}

*Electric only, for typical systems under development in 2003. Estimates are based on fuel cell system developers' goals and prototype characteristics. All estimates are for emissions without after-treatment.

Source: Energy and Environmental Analysis, Inc./Energy Nexus Group.

\footnotetext{
${ }^{28}$ Emissions estimates are based on best available data from manufacturers and customers. Emissions expressed in $\mathrm{lb} / \mathrm{MWh}$ are for electric-only performance and do not credit emissions reductions resulting from CHP operations.

${ }^{29}$ Conversion from volumetric emission rate (ppmv at $\left.15 \% \mathrm{O}_{2}\right)$ to output based rate $(\mathrm{lb} / \mathrm{MWh})$ for $\mathrm{NO}_{2}, \mathrm{CO}_{\text {, and }}$ VOC are based on the following conversion multipliers: $\left(0.01418 \mathrm{lb} / \mathrm{MWh}\right.$ per ppm $\left.\mathrm{NO}_{2}\right)$ times $($ System Elec Efficiency, LHV); (0.00977 lb/MWh per ppm of CO) times (System Elec Efficiency, LHV); and (0.00593 lb/MWh per ppm of VOC) times (System Elec Efficiency, LHV), respectively.
} 


\subsection{System Emissions}

Table 5 shows the emissions characteristics of fuel cell systems. Fuel cell systems do not require any emissions-control devices to meet current and projected regulations.

\subsection{Key Technology Objectives}

Developers and manufacturers of fuel cell systems, with government support, have pursued significant RD\&D efforts for fuel cells based on their potential for high efficiency and minimal environmental impact. Efforts have focused on technology and product research, leading to system demonstrations and, in the case of PAFC, to sustained commercial use. The critical challenge for all fuel cell systems is cost reduction and increasing operating life. Other challenges include increasing system efficiency and power density, reducing maintenance costs, extending maintenance intervals, and validating product durability. The pace of technology advancements in fuel cell systems has accelerated with the support of the PEMFC technology by the automotive industry and the realization that smaller, modular systems provide viable technology validation platforms and potentially economically feasible products.

Since only PAFC technology has reached the market introduction stage, it is the only fuel cell system with specific product goals based on application experience and substantial customer feedback. The primary development issues for PAFC are cost reduction and performance improvements. The PAFC is projected to be phased-out in favor of similarly sized PEMFC systems that offer advantages in terms of efficiency and cost.

PEMFC developers are moving rapidly to introduce initial products through prototype field demonstrations, including systems in the $5-10 \mathrm{~kW}$ and $150-250 \mathrm{~kW}$ ranges. Principal issues with PEMFCs are their limited $\mathrm{CO}$ tolerance and the requirements for precise water management to prevent membrane drying, shrinkage, and loss of ionic conduction. Work continues on stack technology improvements to increase operating temperature, improve tolerance to $\mathrm{CO}$ and other impurities, improve materials durability, enhance water management, and increase power density. Low-cost membranes that function above the boiling point of water with a minimum of hydration requirements are currently being tested at a number of institutions. If successful, this will significantly reduce the complexity of water-management systems in PEMFC power plants.

Developers are optimizing system configurations and component selection to enhance reliability and reduce the cost of planned early-market systems. Significant stack cost reductions over the longer term are expected to be realized through the production of PEMFC Membrane Electrode Assemblies (MEAs) as commodities by multiple suppliers. Developers are also conducting design-for-manufacturing/design-for-assembly (DFM/DFA) analyses to simplify manufacturing and construction costs. Aggressive funding of PEMFC technology development by the automotive industry opens the possibility that low-cost, automotive-derivative PEMFCs with integrated hydrogen-storage capability will be available in the future. With aggressive cost targets required to compete as a mobile power source, "instant-on" capability, and unlimited load-following potential, these hydrogen-fueled fuel cells, if successful, could be used as standby units or for limited peak-shaving applications. Developers are also pursuing inverter cost reductions over the near term for small PEMFC units. 
A major technical challenge for MCFC is the corrosive nature of the electrolyte and its migration, or leakage from the stack. Other problems include slow dissolution of nickel from the cathode, which limits long-term durability, and the requirement for both air and carbon dioxide in the oxidant, both of which are necessary for forming the carbonate ions used in the electrolyte. $\mathrm{CO}_{2}$ can be added to the air supply by recycling it from the anode exhaust gas, but this adds to system complexity and cost. Development efforts continue on both of these issues. The MCFC technology agenda has progressed from engineering research to manufacturing and process developments. Early demonstration problems linked to auxiliary systems or construction methods have been addressed. The leading developer has defined an initial product configuration in the $250 \mathrm{~kW}$ class range and is offering initial pre-commercial units on a limited basis. The product includes simplified balance-of-plant (the subsystems other than the fuel cell stack) design, but capital cost estimates appear to remain outside the market's cost tolerance and stack replacement cost estimates add an additional economic burden. Therefore, the focus of current commercial development efforts is on process integration to simplify balance-of-plant, reduce product cost, and improve system efficiency. Efforts also are centered on improved catalytic combustion systems for $\mathrm{CO}_{2}$ recycle loops.

The two principal SOFC approaches are tubular and planar designs. Tubular technology is at a near-commercial design stage and single cells have operated for more than 20,000 hours. The first products will be in the 100 to $250 \mathrm{~kW}$ range for CHP systems operating at atmospheric pressure. Planar technology has potential cost advantages, but is at an earlier stage of development (note: the SECA program described below is focused on the development of a 5 $\mathrm{kW}$ planar fuel cell system for mass production). However, technology and research goals for SOFC have progressed from fundamental materials and stack design to product development and alternative large-scale, process-integration studies. Areas of technical challenge for planar SOFC include high-temperature seals and gas manifolds, component fragility, and scale-up from laboratory to commercial-size stacks. Planar development efforts focus on fundamental materials and processing technologies for stack and component fabrication to improve power densities, cost-effective metal interconnect materials for lower temperature $\left(700^{\circ} \mathrm{F}\right)$ stack configurations, and alternative materials and engineering approaches for stack cell-to-cell sealing at elevated temperatures and thermal cycling. Tubular SOFC development efforts are currently focused on cost reduction through process integration and simplification and the validation of these at the first commercial SOFC manufacturing facility at $15 \mathrm{MW} /$ year capacity ${ }^{30}$. Work also continues on the design of a tubular SOFC/gas turbine hybrid system with total system electrical efficiency approaching 65\%. The federal government has initiated an effort within the past several years directed at developing the potential of small-scale (5- to 10-kW class), modular SOFC technologies targeted for a wide range of applications from CHP to automotive and auxiliary power.

\footnotetext{
${ }^{30}$ The SOFC manufacturing facility plans were on hold as of the date of this report 


\section{Major Ongoing Development Efforts}

\section{Solid State Energy Conversion Alliance (SECA)}

The U.S. Department of Energy recently launched a program called the Solid State Energy Conversion Alliance (SECA) to create a solid-state fuel cell module that can be produced at a cost of no more than $\$ 400 / \mathrm{kW}$. SECA is a collaboration of U.S. government, industry, universities, and other research organizations, and is being coordinated by the National Energy Technology Laboratory and the Pacific Northwest National Laboratory. SECA is attempting to jump-start competitive, commercial SOFC production while attacking existing barriers to development. The basic building block of the proposed SECA fuel cell is a compact, lightweight, $5 \mathrm{~kW}$ modular unit that can be mass-produced, obviating the need to design and custom-build fuel cell stacks for each individual application. The proposed design leverages recent advances, such as precise, automated manufacturing technologies and thin-film, solid electrolyte materials. Stationary applications are envisioned to range from individual residences to multi-megawatt central power stations, while mobile applications include electric vehicles and ship propulsion.

\section{High-Temperature PEMFC Technologies}

One of the most difficult issues with PEMFC is their almost complete intolerance to CO (current specifications require less than $100 \mathrm{ppm}$ ). Although baseline fuel-processing technologies use a preferential oxidation reactor (PROX) to achieve these specifications, product capital cost, efficiency, and transient response characteristics are all adversely affected. If the operating temperature of PEMFCs could be increased to more than $300^{\circ} \mathrm{F}$, the $\mathrm{CO}$ tolerance and water management would be enhanced. Developers have focused advanced programs on highertemperature systems and have entered into relationships with materials suppliers with critical technologies.

\section{Hybrid Fuel Cell and Microturbine Integration}

Essentially all modern engines above $300 \mathrm{~kW}$ are turbocharged to achieve higher power densities. The hybrid high-temperature fuel cell and microturbine integrated system is similar in many respects. The high-temperature fuel cell is used as the topping cycle, extracting the optimal electric energy out of the fuel source initially. The byproduct heat derived from the inefficiencies of the fuel cell is combined in a catalytic process, in which the unused fuel in the anode off-gases is burned, with the excess oxygen from the cathode off-gas. This combustion boosts the process temperature high enough to drive a gas turbine. The turbine exhaust then preheats the processes feeds to the fuel cell and partially reforms the primary fuel (this reforming is called chemical recuperation). These cycles are at the forefront of advanced technology developments in fuel cell systems. Cycle efficiencies in excess of $65 \%$ HHV are projected.

\section{Enhanced Oxygen and Hydrogen Concentrations}

Automotive fuel cells are being developed with a set of constraints that differ from those of stationary fuel cells. However, many of the innovations may find applications in stationary distributed generation fuel cells systems. One example is the use of low-pressure (2 to 3 atmosphere) pressure-swing absorption devices to enhance and purify either the anode or cathode feed gas. These units increase the reactant partial pressure, enhancing stack performance. The trade-off is similar to that of simple pressurization. To be effective, the performance 
enhancements must be greater than the increased auxiliary load required to compress the feed gases; and the cell stack cost reductions achieved must exceed the additional capital cost of the auxiliary equipment.

\subsection{Advanced Technology Projections}

Progress in the development of fuel cells has, in the past, been more rapid in areas of performance improvement than in cost reduction. Technical performance targets and market cost requirements have often seemed disconnected in the development of fuel cell systems. While the achievement rate for engineering performance targets has been high, the rate of achievement of product cost targets has been low. Adequate electrical and thermal efficiency have been demonstrated in prototype and field-demonstration units. Even acceptable durability and reliability characteristics have been achieved. Capital costs, however, continue to be excessive; which, in turn, limits market acceptance and prevents the manufacturing advances needed to reduce capital cost. Significant private- and public-sector investments will be needed to help overcome these limitations and allow fuel cells to begin a more evolutionary improvement as the technology and markets mature during the next 30 years.

There are several classes of improvements in fuel cells that are expected to increase their attractiveness for on-site and distributed power generation:

- Capital costs of market-entry products will be improved as manufacturers simplify balance-of-plant design and stack component manufacturing. The fact that several major technology firms have focused on second-tier product strategies ${ }^{31}$ should both level the product performance playing field and enhance marketplace competition. Similar second-tier strategies are expected with material and suppliers of SOFC components. Adoption of PEMFC technology by the automotive industry - even in relatively limited volumes - will provide a critical increase in demand to allow them to enhance manufacturing technologies, further drive the commoditization of the MEA and inverters, and allow more competitive distributed generation fuel cell systems. The manufacture of automotive fuel cells would not be transferable directly to the manufacture of stationary fuel cells because their required lifetimes and other service characteristics are very different. General Motors now says that stationary fuel cell market applications will lead the automotive fuel cell applications. In June 2003, GM announced plans to build 500 70kW stationary PEM fuel cells for Dow Chemical's complex in Freeport, Texas. Deliveries are expected to begin in late 2003.

- SOFC efficiencies will improve through integrated fuel processing and stack functionality within compact heat exchange configurations. The modular nature of the developing building-block stack subsystem component with application flexibilities will enhance market entry and minimize product development and engineering costs.

- The PAFC power plant and marketplace experience to-date promise to provide a solid foundation for PEMFC products in the $150-250 \mathrm{~kW}$ class.

\footnotetext{
${ }^{31}$ E.g., 3M and Gore marketing membrane-electrode assemblies (MEA) to developers; Engelhard and Johnson Matthey marketing reformer catalysts.
} 
- The most critical issue with MCFC technology is the durability of stacks and components. Efforts to introduce a $250 \mathrm{~kW}$ class product in the near term should provide the market-based experience that validates developer solutions to these critical issues. Component manufacturing technologies and processes have been validated over the past decade of RD\&D projects. In addition to the high installed cost, customer acceptance and product durability are the critical issues facing successful market entry.

- More effective packaging and integration of systems and controls will reduce the cost of the basic components. On-site cost of installation can be reduced by greater standardization of design and auxiliary components. A modular approach with greater factory assembly can greatly reduce site costs, particularly for smaller systems.

- The cost of installing CHP plants will decline if states adopt streamlined siting, interconnection, and permitting procedures that allow greater standardization of CHP components and packages. Unlike other improvements, this requires changes in government policy that will allow changes in technology and shorter lead times.

\section{Future Performance}

Table 6 summarizes the nature and timing of performance advances projected to occur between now and 2030. Table 7 presents projections of the future performance of the six fuel cell CHP systems profiled previously, based on the advances shown in Table 6. 
Table 6. Projected Fuel Cell Evolution Through 2030

\begin{tabular}{|c|c|c|c|c|c|}
\hline $\begin{array}{l}\text { Current } \\
\text { Unit }\end{array}$ & Current Characteristics & 2005 & 2010 & 2020 & 2030 \\
\hline $\begin{array}{l}200 \mathrm{~kW} \\
\text { PAFC }\end{array}$ & $\begin{array}{l}\text { Production limited to } \\
\text { under } 50 \text { units/year } \\
\text { Graphite interconnect } \\
\text { plate structures }\end{array}$ & $\begin{array}{l}\text { Production remains } \\
\text { limited as product is } \\
\text { phased out } \\
\text { No change in technology } \\
\text { basis }\end{array}$ & N/A & $\mathrm{N} / \mathrm{A}$ & N/A \\
\hline $\begin{array}{l}5-10 \mathrm{~kW} \\
\text { PEMFC }\end{array}$ & $\begin{array}{l}\text { Field-demo production } \\
\text { Graphite/metal/ } \\
\text { conductive plastic } \\
\text { interconnect plates }\end{array}$ & $\begin{array}{l}\text { Initial production } \\
\text { beginning }\end{array}$ & $\begin{array}{l}\text { Automated stack } \\
\text { production established } \\
\text { Ancillary component } \\
\text { integration begins } \\
\text { Multiple MEA } \\
\text { manufacturers in } \\
\text { competition } \\
\text { Conductive plastic } \\
\text { interconnect plates } \\
\end{array}$ & $\begin{array}{l}\text { MEA commodity pricing } \\
\text { Higher temp PEM } \\
\text { Auto. cat. converter design } \\
\text { and mfg adopted for } \\
\text { reformer } \\
\text { Plastic and aluminum HX } \\
\text { Power conditioning } \\
\text { commoditized }\end{array}$ & $\begin{array}{l}\text { Automotive-style } \\
\text { DFM/DFA established } \\
\text { for sensor and control } \\
\text { assemblies } \\
\text { Product reaches appliance }\end{array}$ \\
\hline $\begin{array}{l}150-250 \\
\mathrm{~kW} \\
\text { PEMFC }\end{array}$ & $\begin{array}{l}\text { Prototype demo units } \\
\text { Prototype automotive } \\
\text { stack production } \\
\text { See } 10 \mathrm{~kW} \text { PEMFC }\end{array}$ & $\begin{array}{l}\text { Same as current } \\
\text { Pure } \mathrm{H}_{2} \text { systems adapted } \\
\text { to DG applications }\end{array}$ & $\begin{array}{l}\text { PEMFC stacks applied to } \\
\text { PAFC product } \\
\text { configuration adopted } \\
\text { See } 10 \mathrm{~kW} \text { PEMFC }\end{array}$ & $\begin{array}{l}\text { Power-conditioning learning } \\
\text { See } 10 \mathrm{~kW} \text { PEMFC }\end{array}$ & $\begin{array}{l}\text { Reformer technology } \\
\text { enters mass mfg } \\
\text { techniques }\end{array}$ \\
\hline $\begin{array}{l}250 \mathrm{~kW} \\
\mathrm{MCFC}\end{array}$ & $\begin{array}{l}\text { Initial production } \\
\text { facility in start-up, } \\
\text { limited commercial } \\
\text { availability }\end{array}$ & Same as current & $\begin{array}{l}\text { Limited scale production } \\
\text { Integrated reformer } \\
\text { functionality enhanced }\end{array}$ & $\begin{array}{l}\text { Stack production learning } \\
\text { Power-conditioning learning }\end{array}$ & $\begin{array}{l}\text { Ancillary components } \\
\text { commoditized }\end{array}$ \\
\hline $\begin{array}{l}2000 \mathrm{~kW} \\
\mathrm{MCFC}\end{array}$ & $\begin{array}{l}\text { Validation of } \\
\text { technology at } 250 \\
\mathrm{~kW}\end{array}$ & Same as current & $\begin{array}{l}\text { Technical risk eliminated } \\
\text { Microturbine integration }\end{array}$ & $\begin{array}{l}\text { Microturbine integration } \\
\text { becomes baseline }\end{array}$ & $\begin{array}{l}\text { Product and production } \\
\text { learning }\end{array}$ \\
\hline $\begin{array}{l}100-250 \\
\mathrm{~kW} \\
\mathrm{SOFC}\end{array}$ & $\begin{array}{l}\text { Tubular configuration } \\
\text { Vapor depositions } \\
\text { automated }\end{array}$ & $\begin{array}{l}\text { Planar designs begin } \\
\text { validation } \\
\text { SECA modular } \\
\text { demonstrations begin }\end{array}$ & $\begin{array}{l}\text { Microturbine integration } \\
\text { Planar sealing resolved } \\
\text { Vapor deposition } \\
\text { eliminated } \\
\text { Integrated reformer } \\
\text { hardware } \\
\end{array}$ & $\begin{array}{l}\text { Materials grade reduced } \\
\text { Microturbine integration } \\
\text { becomes baseline } \\
\text { Power conditioning } \\
\text { commoditized }\end{array}$ & $\begin{array}{l}\text { Ancillary components } \\
\text { commoditized } \\
\text { Internal reforming } \\
\text { Cooling resolved at high } \\
\text { power densities }\end{array}$ \\
\hline
\end{tabular}


Table 7. Current and Advanced Fuel Cell System Characteristics ${ }^{32}$

\begin{tabular}{|c|c|c|c|c|c|}
\hline \multicolumn{6}{|l|}{$\begin{array}{l}\text { Cost and Performance Projections } \\
200 \mathrm{~kW} \text { PAFC Fuel Cell CHP System }\end{array}$} \\
\hline Year & Current & 2005 & 2010 & 2020 & 2030 \\
\hline Fuel Cell Technology & PAFC & PAFC & PAFC & PAFC & PAFC \\
\hline System Size, kW & 200 & 200 & - & - & - \\
\hline Total Installed Cost $(2003 \$ / \mathrm{kW})^{33}$ & 5,200 & 5,200 & - & - & - \\
\hline O\&M Costs $(2003 \$ / k W h)$ & 0.029 & 0.029 & - & - & - \\
\hline Electrical Heat Rate $(\mathrm{Btu} / \mathrm{kWh}$ & 9,480 & 9,480 & - & - & - \\
\hline Electrical Efficiency $(\%)^{34}$ & 36 & 36 & - & - & - \\
\hline Fuel Input (MMBtu/hr) & 1.90 & 1.90 & - & - & - \\
\hline \multicolumn{6}{|l|}{ CHP Characteristics } \\
\hline Total CHP Efficiency (\%) & 72 & 72 & - & - & - \\
\hline Heat Output (MMBtu/hr) & 0.68 & 0.68 & - & - & - \\
\hline Power/Heat Ratio & 1.0 & 1.0 & - & - & - \\
\hline Net Heat Rate (Btu/kWh) & 5,215 & 5,215 & - & - & - \\
\hline \multicolumn{6}{|l|}{ Emissions Characteristics } \\
\hline $\mathrm{NO}_{\mathrm{x}}(\mathrm{lb} / \mathrm{MWh})$ & 0.04 & 0.04 & - & - & - \\
\hline $\mathrm{CO} \quad(\mathrm{lb} / \mathrm{MWh})$ & 0.05 & 0.05 & - & - & - \\
\hline VOC (lb/MWh) & 0.01 & 0.01 & - & - & - \\
\hline $\mathrm{CO}_{2}(\mathrm{lb} / \mathrm{MWh})$ & 1,135 & 1,140 & - & - & - \\
\hline
\end{tabular}

Source: Energy and Environmental Analysis, Inc., projections based on publicly available data for commercially available systems and manufacturers' market entry targets for market introduction systems (current year,) and on manufacturer RD\&D targets for out-years.

\footnotetext{
${ }^{32}$ Current characteristics of systems presented are representative of fuel cell CHP systems currently commercially available or in market introduction. Estimates for 2005 based on market entry target performance for fuel cell systems under development. Table data are based on public information, industrial interviews, and development targets. Since most of these systems are still not commercially available, actual values in future service may vary substantially.

${ }^{33}$ Installed costs are based on CHP systems producing hot water from available heat recovery streams

${ }^{34}$ Electrical efficiencies are net of parasitic and power conversion losses.
} 
Table 7 (cont'd.) Current and Advanced Fuel Cell System Characteristics

\begin{tabular}{|c|c|c|c|c|c|}
\hline \multicolumn{6}{|l|}{$\begin{array}{l}\text { Cost and Performance Projections } \\
\text { 5-10 kW PEMFC CHP System }\end{array}$} \\
\hline Year & Current & 2005 & 2010 & 2020 & 2030 \\
\hline Fuel Cell Technology & & PEMFC & PEMFC & PEMFC & PEMFC \\
\hline System Size, kW & & 10 & 10 & 10 & 10 \\
\hline Total Installed Cost $(2003 \$ / \mathrm{kW})$ & & 5,500 & 3,800 & 2,200 & 1,300 \\
\hline O\&M Costs $(2003 \$ / k W h)$ & & 0.033 & 0.023 & 0.019 & 0.016 \\
\hline Electrical Heat Rate (Btu/kWh) & & 11,370 & 10,660 & 9,750 & 9,480 \\
\hline Electrical Efficiency (\%) & & 30 & 32 & 35 & 36 \\
\hline Fuel Input (MMBtu/hr) & & 0.11 & 0.11 & 0.10 & 0.09 \\
\hline \multicolumn{6}{|l|}{ CHP Characteristics } \\
\hline Total CHP Efficiency (\%) & & 69 & 70 & 72 & 73 \\
\hline Heat Output (MMBtu/hr) & & 0.04 & 0.04 & 0.04 & 0.03 \\
\hline Power/Heat Ratio & & 0.79 & 0.83 & 0.94 & 0.96 \\
\hline Net Heat Rate $(\mathrm{Btu} / \mathrm{kWh})$ & & 5,825 & 5,542 & 5,229 & 5,044 \\
\hline \multicolumn{6}{|l|}{ Emissions Characteristics } \\
\hline $\mathrm{NO}_{\mathrm{x}}(\mathrm{lb} / \mathrm{MWh})$ & & 0.06 & 0.06 & 0.05 & 0.05 \\
\hline $\mathrm{CO} \quad(\mathrm{lb} / \mathrm{MWh})$ & & 0.07 & 0.06 & 0.06 & 0.06 \\
\hline VOC (lb/MWh) & & 0.01 & 0.01 & 0.01 & 0.01 \\
\hline $\mathrm{CO}_{2}(\mathrm{lb} / \mathrm{MWh})$ & & 1,360 & 1,280 & 1,170 & 1,140 \\
\hline
\end{tabular}


Table 7 (cont'd.) Current and Advanced Fuel Cell System Characteristics

\begin{tabular}{|c|c|c|c|c|c|}
\hline \multicolumn{6}{|l|}{$\begin{array}{l}\text { Cost and Performance Projections } \\
\text { 200-250 kW PEMFC CHP System }\end{array}$} \\
\hline Year & Current & 2005 & 2010 & 2020 & 2030 \\
\hline Fuel Cell Technology & & PEMFC & PEMFC & PEMFC & PEMFC \\
\hline System Size, kW & & 150 & 150 & 150 & 150 \\
\hline Total Installed Cost $(2003 \$ / \mathrm{kW})$ & & 3,800 & 2,700 & 1,700 & 1,100 \\
\hline O\&M Costs $(2003 \$ / k W h)$ & & 0.023 & 0.015 & 0.012 & 0.011 \\
\hline Electrical Heat Rate (Btu/kWh) & & 9,750 & 9,480 & 8,980 & 8,980 \\
\hline Electrical Efficiency (\%) & & 35 & 36 & 38 & 38 \\
\hline Fuel Input (MMBtu/hr) & & 1.95 & 1.90 & 1.80 & 1.80 \\
\hline \multicolumn{6}{|l|}{ CHP Characteristics } \\
\hline Total CHP Efficiency (\%) & & 72 & 73 & 75 & 75 \\
\hline Heat Output (MMBtu/hr) & & 0.72 & 0.70 & 0.66 & 0.66 \\
\hline Power/Heat Ratio & & 0.95 & 0.98 & 1.04 & 1.04 \\
\hline Net Heat Rate $(B t u / k W h)$ & & 5,250 & 5,108 & 4,865 & 4,865 \\
\hline \multicolumn{6}{|l|}{ Emissions Characteristics } \\
\hline $\mathrm{NO}_{\mathrm{x}}(\mathrm{lb} / \mathrm{MWh})$ & & 0.1 & 0.07 & 0.05 & 0.05 \\
\hline $\mathrm{CO} \quad(\mathrm{lb} / \mathrm{MWh})$ & & 0.07 & 0.04 & 0.04 & 0.04 \\
\hline VOC (lb/MWh) & & 0.01 & $<0.01$ & $<0.01$ & $<0.01$ \\
\hline $\mathrm{CO}_{2}(\mathrm{lb} / \mathrm{MWh})$ & & 1,170 & 1,140 & 1,080 & 1,080 \\
\hline
\end{tabular}


Table 7 (cont'd.) Current and Advanced Fuel Cell System Characteristics

\begin{tabular}{|c|c|c|c|c|c|}
\hline \multicolumn{6}{|c|}{$\begin{array}{l}\text { Cost and Performance Projections } \\
250 \mathrm{~kW} \text { MCFC Fuel Cell CHP System }\end{array}$} \\
\hline Year & Current & 2005 & 2010 & 2020 & 2030 \\
\hline Fuel Cell Technology & MCFC & MCFC & MCFC & MCFC & MCFC \\
\hline System Size, kW & 250 & 250 & 250 & 250 & 250 \\
\hline Total Installed Cost $(2003 \$ / \mathrm{kW})$ & 5,000 & 5,000 & 3,400 & 2,100 & 1,500 \\
\hline O\&M Costs $(2003 \$ / \mathrm{kWh})$ & 0.043 & 0.032 & 0.026 & 0.020 & 0.012 \\
\hline Electrical Heat Rate (Btu/kWh) & 7,930 & 7,930 & 7,580 & 6,920 & 6,960 \\
\hline Electrical Efficiency (\%) & 43 & 43 & 45 & 49 & 49 \\
\hline Fuel Input (MMBtu/hr) & 1.98 & 1.98 & 1.90 & 1.74 & 1.74 \\
\hline \multicolumn{6}{|l|}{ CHP Characteristics } \\
\hline Total Efficiency (\%) & 65 & 65 & 68 & 72 & 72 \\
\hline Heat Output (MMBtu/hr) & 0.44 & 0.44 & 0.43 & 0.40 & 0.40 \\
\hline Power/Heat Ratio & 1.95 & 1.95 & 1.98 & 2.13 & 2.13 \\
\hline Net Heat Rate (Btu/kWh) & 5,750 & 5,750 & 5,450 & 4,960 & 4,960 \\
\hline \multicolumn{6}{|l|}{ Emissions Characteristics } \\
\hline $\mathrm{NO}_{\mathrm{x}}(\mathrm{lb} / \mathrm{MWh})$ & 0.06 & 0.06 & 0.05 & 0.04 & 0.04 \\
\hline $\mathrm{CO}(\mathrm{lb} / \mathrm{MWh})$ & 0.04 & 0.04 & 0.04 & 0.03 & 0.03 \\
\hline VOC (lb/MWh) & 0.01 & 0.01 & $<0.01$ & $<0.01$ & $<0.01$ \\
\hline $\mathrm{CO}_{2}(\mathrm{lb} / \mathrm{MWh})$ & 950 & 950 & 908 & 834 & 834 \\
\hline
\end{tabular}


Table 7 (cont'd.) Current and Advanced Fuel Cell System Characteristics

\begin{tabular}{|c|c|c|c|c|c|}
\hline \multicolumn{6}{|c|}{$\begin{array}{l}\text { Cost and Performance Projections } \\
2,000 \mathrm{~kW} \text { MCFC Fuel Cell CHP System }\end{array}$} \\
\hline Year & Current & 2005 & 2010 & 2020 & 2030 \\
\hline Fuel Cell Technology & & MCFC & MCFC & MCFC & $\mathrm{MCFC}$ \\
\hline System Size, kW & & 2,000 & 2,000 & 2,000 & 2,000 \\
\hline Total Installed Cost (2003 \$/kW) & & 3,250 & 2,400 & 1,600 & 1,200 \\
\hline O\&M Costs $(2003 \$ / \mathrm{kWh})$ & & 0.033 & 0.019 & 0.014 & 0.011 \\
\hline Electrical Heat Rate (Btu/kWh) & & 7,420 & 7,110 & 6,820 & 6,560 \\
\hline Electrical Efficiency (\%) & & 46 & 48 & 50 & 52 \\
\hline Fuel Input (MMBtu/hr) & & 14.80 & 14.22 & 13.64 & 13.12 \\
\hline \multicolumn{6}{|l|}{ CHP Characteristics } \\
\hline Total Efficiency (\%) & & 70 & 72 & 72 & 75 \\
\hline Heat Output (MMBtu/hr) & & 3.56 & 3.41 & 3.0 & 3.0 \\
\hline Power/Heat Ratio & & 1.92 & 2.00 & 2.27 & 2.27 \\
\hline Net Heat Rate (Btu/kWh) & & 5,200 & 4,980 & 4,940 & 4,680 \\
\hline \multicolumn{6}{|l|}{ Emissions Characteristics } \\
\hline $\mathrm{NO}_{\mathrm{x}}(\mathrm{lb} / \mathrm{MWh})$ & & 0.05 & 0.05 & 0.04 & 0.04 \\
\hline $\mathrm{CO} \quad(\mathrm{lb} / \mathrm{MWh})$ & & 0.04 & 0.03 & 0.03 & 0.03 \\
\hline VOC (lb/MWh) & & 0.01 & $<0.01$ & $<0.01$ & $<0.01$ \\
\hline $\mathrm{CO}_{2}(\mathrm{lb} / \mathrm{MWh})$ & & 890 & 850 & 820 & 790 \\
\hline
\end{tabular}


Table 7 (cont'd.) Current and Advanced Fuel Cell System Characteristics

\begin{tabular}{|c|c|c|c|c|c|}
\hline \multicolumn{6}{|c|}{\begin{tabular}{|l} 
Cost and Performance Projections \\
$100-250$ kW SOFC Fuel Cell CHP System
\end{tabular}} \\
\hline Year & Current & 2005 & 2010 & 2020 & 2030 \\
\hline Fuel Cell Technology & & SOFC & SOFC & SOFC & SOFC \\
\hline System Size, kW & & 100 & 100 & 100 & 100 \\
\hline Total Installed Cost $(2003 \$ / \mathrm{kW})$ & & 3,620 & 2,500 & 1,800 & 1,100 \\
\hline O\&M Costs $(2003 \$ / \mathrm{kWh})$ & & 0.024 & 0.016 & 0.015 & 0.013 \\
\hline Electrical Heat Rate (Btu/kWh) & & 7,580 & 6,960 & 6,690 & 6,440 \\
\hline Electrical Efficiency (\%) & & 45 & 49 & 51 & 53 \\
\hline Fuel Input (MMBtu/hr) & & 0.80 & 0.70 & 0.67 & 0.64 \\
\hline \multicolumn{6}{|l|}{ CHP Characteristics } \\
\hline Total Efficiency (\%) & & 70 & 72 & 72 & 75 \\
\hline Heat Output (MMBtu/hr) & & 0.19 & 0.16 & 0.14 & 0.14 \\
\hline Power/Heat Ratio & & 1.79 & 2.13 & 2.43 & 2.41 \\
\hline Net Heat Rate (Btu/kWh) & & 5,210 & 4,960 & 4,940 & 4,670 \\
\hline \multicolumn{6}{|l|}{ Emissions Characteristics } \\
\hline $\mathrm{NO}_{\mathrm{x}}(\mathrm{lb} / \mathrm{MWh})$ & & 0.05 & 0.05 & 0.04 & 0.04 \\
\hline $\mathrm{CO} \quad(\mathrm{lb} / \mathrm{MWh})$ & & 0.04 & 0.03 & 0.03 & 0.03 \\
\hline VOC (lb/MWh) & & 0.01 & $<0.01$ & $<0.01$ & $<0.01$ \\
\hline $\mathrm{CO}_{2}(\mathrm{lb} / \mathrm{MWh})$ & & 910 & 834 & 801 & 772 \\
\hline
\end{tabular}




\subsection{References}

Arthur D. Little, Corp, Technology Forecast Updates - Residential and Commercial Building Technology, Report for U.S DOE EIA, September 1998.

Cambridge Energy Research Associates, The Next Generation: Fuel Cells and Microturbines, January 1998.

Directed Technologies, Inc., Manufacturing Costs of Stationary PEM Fuel Cell Systems, Report for NREL, November 1999.

Directed Technologies, Inc., DFMA Cost Estimates of Fuel Cell/Reformer Systems at Low/Medium/High Production Rates, Future Car Congress, 2002.

Energy Nexus Group, Performance and Cost Trajectories of Clean Distributed Generation Technologies, Prepared for The Energy Foundation, May 29, 2002.

EG\&G Services, Parsons, Inc., and Science Applications International Corporation, Fuel Cell Handbook Fifth Edition, Report for the U.S. Department of Energy, October 2000.

FuelCell Energy, 250 kW Direct Fuel Cell Powerplant Specification Summary, 2002.

Geyer, B, "Developments in Fuel Cell Technology," Fuel Cells 2000, Sustainable Development International, April 1999.

Imperial College Centre for Energy Policy and Technology, Fuel Cell Market Prospects and Intervention Strategies, Report for the United Nations Environment Programme, January 2002.

Kordesch, K., Simador, G. Fuel Cells and Their Applications, UCH Press, New York, 1996.

Larminie, James, and Andrew Dicks, Fuel Cell Systems Explained, John Wiley \& Sons, Ltd., West Sussex, England, 2000.

Next Generation Fuel Cells Workshop: Workshop Proceedings - Federal Energy Technology Center, 3610 Collins Ferry Road, P.O. Box 880, Morgantown, WV 26507-0880, December 1998.

Steigelmann, W., "The Business Case for Fuel Cell Technology: Applications, Economic Analysis and Commercial Opportunities," AdvanceTech Monitor, Woburn, MA, September 1999.

Venture Development Corporation, Grid Power Solutions: The North American Market for Distributed Generation and Ride-Through Technologies.

Winters, R. K., Bear Stearns, Distributed Energy Services: The World's Power and Transportation Industries - Set for a Revolution, April 2000. 
Fuel cell developers:

Acumentrics Corportation (SOFC), www.acumentrics.com

Anuva Corporation (PEMFC), www.anuva.com

Avista Laboratories (PEMFC), www.avistalabs.com

Ballard Power Systems, Inc. (PEMFC), www.ballard.com

Ceramatec, Inc. (SOFC), www.ceramatec.com

Ceramic Fuel Cells, Ltd (SOFC), www.cfcl.com.au

Electrochem, Inc. (PEM), www.fuelcell.com

FuelCell Energy (MCFC), www.fce.com

Hydrogenics Corporation (PEMFC), www.hydrogenics.com

IdaTech (PEMFC), www.idatech.com

McDermitt Technologies, Inc. (PEMFC, SOFC), www.mtiresearch.com

Mitsubishi Electric Corporation (PAFC), www.mistubishielectric.com

Plug Power, Inc. (PEMFC), www.plugpower.com

Seimens Westinghouse Power Corp (SOFC), www.pg.siemens.com/en/fuelcells

Solid State Energy Conversion Alliance (SOFC), www.seca.doe.gov

Toshiba Corporation (PAFC, PEMFC), www.toshiba.co.jp

UTC Fuel Cells (PAFC, PEMFC), www.utcfuelcells.com

Ztek Corporation (SOFC), www.ztekcorp.com 


\section{Small Steam Turbine Systems}

\subsection{Overview}

Steam turbines are one of the most versatile and oldest prime mover technologies still in general production. Steam turbines have been generating power for more than 100 years, when they first replaced reciprocating steam engines because of their higher efficiencies and lower costs. Most of the electricity produced in the United States today is generated by conventional steam turbine power plants. The capacity of commercially available steam turbines ranges from $50 \mathrm{~kW}$ to several hundred MW. The range of steam turbines described in this report is from $500 \mathrm{~kW}$ to $15 \mathrm{MW}$, representing the steam turbine systems most likely to be employed for on-site power generation by industrial and institutional users.

Unlike gas turbine and reciprocating engine combined heat and power (CHP) systems - in which heat is a byproduct of power generation - steam turbines normally generate electricity as a byproduct of heat (steam) generation. A steam turbine is captive to a separate heat source and does not directly convert fuel to electric energy. Energy is transferred from the boiler (in which fuel is burned to provide heat for steam generation) to the turbine. This occurs in the form of high-pressure steam that powers the turbine and generator. ${ }^{1}$ This separation of energyconversion functions enables steam turbines to operate with an enormous variety of fuels, ranging from natural gas to solid waste - including all types of coal, wood, wood waste, and agricultural byproducts (sugar cane bagasse, fruit pits, and rice hulls). In CHP applications, steam at lower pressure is extracted from the turbine and used directly in a process, or for district heating; or it can be converted to other forms of thermal energy, including hot or chilled water.

Steam turbines offer a wide array of designs and complexity to match the desired application and/or performance specifications. Steam turbines for utility service may have several pressure casings and elaborate design features, all designed to maximize the efficiency of the power plant. For industrial applications, steam turbines are generally of simpler single-casing design and less complex for reliability and cost reasons. CHP can be adapted to both utility and industrial steam turbine designs.

\subsection{Applications}

While steam turbines are competitively priced compared to other prime movers, the costs of complete, greenfield boiler/steam turbine CHP systems are relatively high on a per $\mathrm{kW}$ of capacity basis because of their low power-to-heat ratio, the costs of the boiler, fuel handling, and overall steam systems, and the custom nature of most installations. Steam turbines are well suited to medium- and large-scale industrial and institutional applications where inexpensive fuels, such as coal, biomass, various solid wastes and byproducts (e.g., wood chips, etc.), refinery residual oil, and refinery off-gases are available. Because of the relatively high cost of the system - including boiler, fuel-handling system, condenser, cooling tower, and stack gas cleanup - high annual capacity factors are required for a reasonable recovery of invested capital.

\footnotetext{
${ }^{1}$ Steam also can be generated with the waste heat of a gas turbine, as in the case of combined-cycle power plants. Gas-Fired Distributed Energy Resource Technology Characterizations Small Steam Turbine Systems - Page 6-1
} 
However, retrofit applications of steam turbines into existing boiler/steam systems can be competitive options for a wide variety of users, depending on the pressure and temperature of the steam exiting the boiler, the thermal needs of the site, and the condition of the existing boiler and steam system. In such situations, the decision involves only the added capital cost of the steam turbine, its generator, controls and electrical interconnection, with the balance of plant already in place. Similarly, many facilities that are faced with replacement or upgrades of existing boilers and steam systems often consider the addition of steam turbines, especially if steam requirements are relatively large compared to power needs within the facility.

In general, steam turbine applications are driven by balancing lower-cost fuel, or avoided disposal costs for a waste fuel, against the high capital cost and (usually high) annual capacity factor for the steam plant and the combined energy plant-process plant application. For these reasons, steam turbines are not normally direct competitors of gas turbines and reciprocating engines in distributed generation applications.

\subsection{Power-Only}

While most often used in combined heat and power mode, steam turbines can be used as poweronly distributed generators in applications that have little or no process steam demand but do have access to inexpensive solid fuels or waste fuels and byproducts such as wood chips or biomass. Condensing turbines are generally used in such applications in order to maximize the electricity or mechanical power that can be produced by burning fuels that otherwise would go to waste. Condensing turbines are also used in bottoming cycles for gas turbines to generate additional power in combined cycle systems. Steam generated from hot gas turbine exhaust in a heat recovery steam generator (HRSG) is used to drive a steam turbine to yield additional electricity and improve cycle electric efficiency.

\subsection{Combined Heat and Power}

Steam turbine-based CHP systems are primarily used in industrial processes and large institutional campuses where low-cost solid or waste fuels are readily available for boiler use. In CHP applications, low-pressure steam is extracted from the steam turbine and used directly in a process or for district heating, or it can be converted to other forms of thermal energy including hot water or chilled water. The turbine may drive an electric generator or equipment such as process pumps, air compressors, and refrigeration chillers. Turbines as industrial drivers are almost always a single-casing machine, either single-stage or multistage, extraction or backpressure, depending on steam conditions and the value of the steam. Steam turbines can operate at a single speed to drive an electric generator or operate over a speed range to drive a compressor.

There were an estimated 19,062 MW of boiler/steam turbine CHP capacity operating in the United States in 2000, located at more than 580 industrial and institutional facilities. As shown in Figure 1, the largest amounts of capacity are found in the chemicals, primary metals, and 
paper industries. Pulp and paper mills are often an ideal industrial/CHP application for steam turbines. These mills operate continuously, have a very high demand for steam, and have on-site fuel supply at low - or even negative - costs (waste that would have to be otherwise disposed of).

Figure 2 illustrates existing steam turbine CHP capacity by boiler fuel type. While much of the installed boiler/steam turbine system base is fueled by coal, large amounts of capacity are fueled by wood, waste, and a wide variety of other fuels.

\section{Figure 1. Existing Boiler/Steam Turbine CHP Capacity by Industry $19,062 \mathrm{MW}$ at 582 Sites}

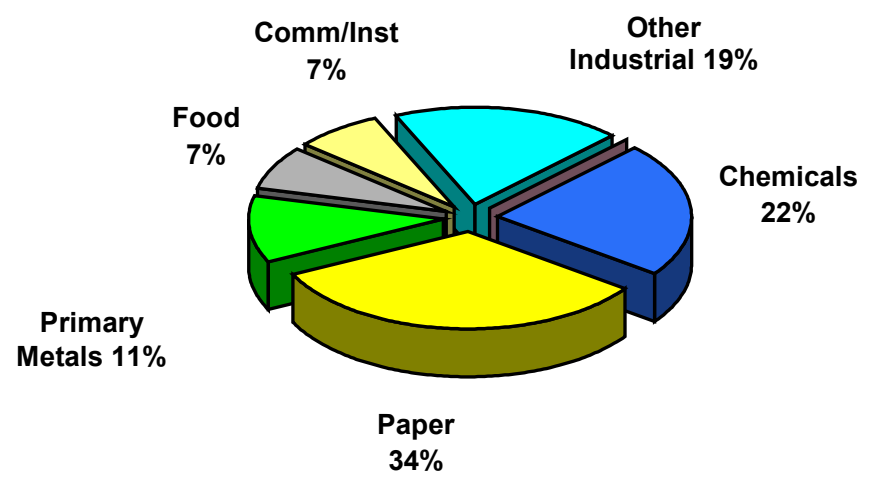

Figure 2. Existing Boiler/Steam Turbine CHP Capacity by Boiler Fuel Type $19,062 \mathrm{MW}$ at 582 Sites

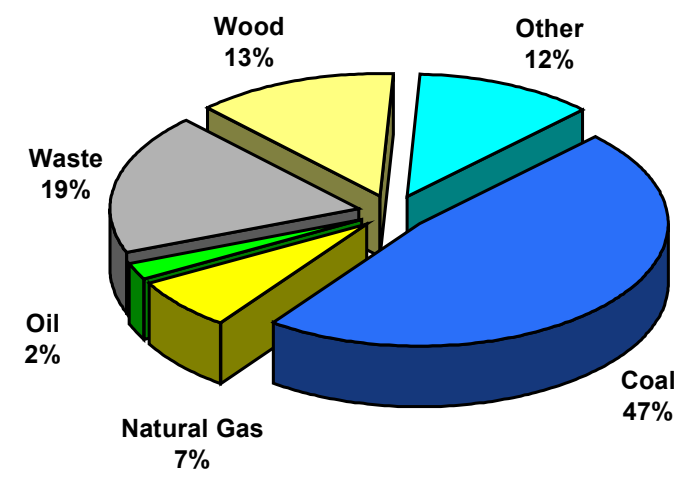

Source: Energy and Environmental Analysis, Inc., EEA CHP 2000 
Combined Cycle Power Plants: One trend in power plant design is the combined-cycle configuration, which incorporates a steam turbine in a bottoming cycle with a gas turbine. Steam generated from hot gas turbine exhaust in a heat recovery steam generator (HRSG) is used to drive a steam turbine to yield additional electricity and improve cycle efficiency. Combinedcycle systems also can be used in CHP applications. In these cases, steam is extracted from the steam turbine to meet process or building thermal needs.

District Heating Systems: Many cities and college campuses have steam district-heating systems, where adding a steam turbine between the boiler and the distribution system may be an attractive application. Often the boiler is capable of producing moderate-pressure steam, but the distribution system needs only low-pressure steam. In these cases, the steam turbine generates electricity using the higher-pressure steam, and discharges low-pressure steam into the distribution system.

\subsection{Technology Description}

Steam turbines differ from reciprocating engines and gas turbines in that the fuel is burned in a boiler, which is separate from the power generation equipment - the steam turbogenerator. The energy is transferred from the boiler to the turbine by pressurized steam. As mentioned previously, this separation of functions enables steam turbines to operate with an enormous variety of fuels. The topic of boiler fuels, their handling, combustion, and the cleanup of the effluents of such combustion is a separate - and complex - issue, which is addressed in the fuels and emissions sections of this report.

For sizes up to (approximately) $40 \mathrm{MW}$, shop-assembled, horizontal watertube industrial boilers are used. Larger boilers are field-erected directly on site. Horizontal boilers can be shipped via rail car, with considerable cost savings over field-erected boilers. Large shop-assembled boilers are typically capable of firing only gas or distillate oil, because there is inadequate residence time for complete combustion of most solid and residual fuels in such designs. Large, field-erected industrial boilers, firing solid and residual fuels, resemble utility boilers.

\subsection{Basic Process and Components}

Conventional power-generating stations use boilers to convert water to high-pressure steam. In the steam cycle, water is first pumped to elevated pressure, which is medium to high pressure, depending on the size of the unit and the temperature to which the steam is eventually heated. The water is then heated to the boiling temperature corresponding to the pressure, boiled (converted from liquid to vapor), and then most frequently superheated (heated to a temperature above that of boiling). The pressurized steam is expanded to lower pressure in a turbine, then exhausted, either to a condenser at vacuum conditions (power-only configuration) or into an intermediate temperature steam-distribution system that delivers the steam to the industrial or commercial application (CHP configuration). The condensate from the condenser or from the industrial steam utilization system is returned to the feedwater pump for continuation of the cycle. 
Primary components of a boiler/steam turbine system are shown in Figure 3.

Figure 3. Components of a Boiler/Steam Turbine System

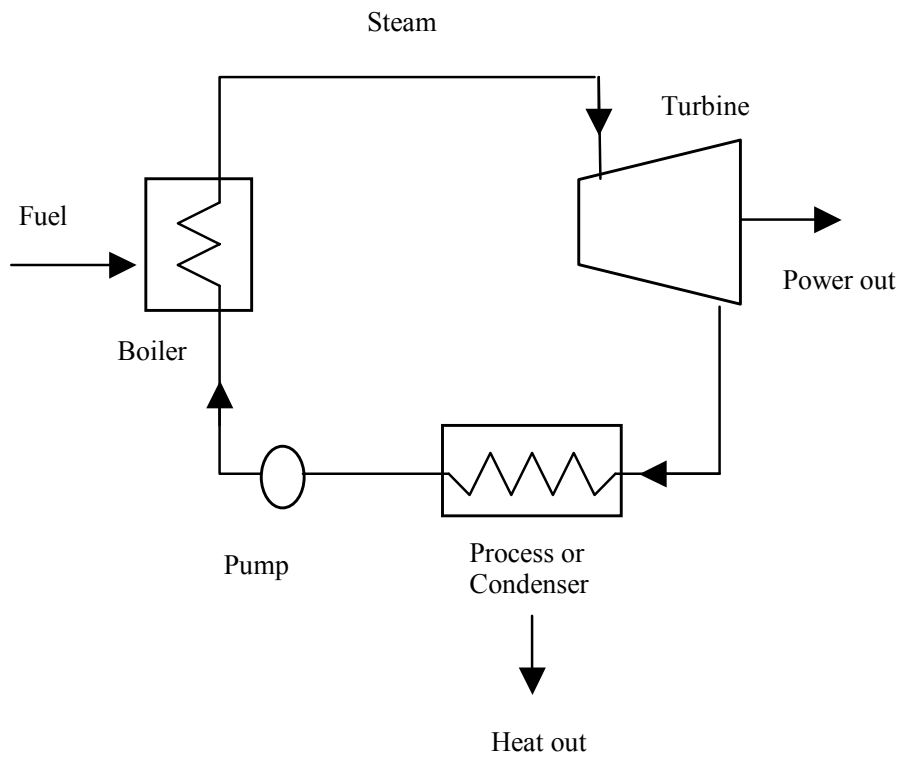

Steam turbines consist of a stationary set of vanes (called nozzles) and a moving set of adjacent blades (called buckets or rotor blades) installed within a casing. The vanes and blades work together so that the steam turns the shaft of the turbine and the connected load. The stationary nozzles accelerate the steam to high velocity by expanding it to lower pressure. A rotating bladed disc changes the direction of the steam flow, thereby creating a force on the blades that, because of the wheeled geometry, manifests itself as torque on the shaft on which the bladed wheel is mounted. The combination of torque and speed is the output power of the turbine. In some steam turbine designs, part of the decrease in pressure and resultant acceleration of the steam is accomplished in the blade row. These distinctions are known as impulse and reaction turbine designs, respectively. The competitive merits of these designs are the subject of business competition, as turbines of each design have been sold successfully for more than 75 years.

The internal flow passages of a steam turbine are very similar to those of the expansion section of a gas turbine. (Indeed, gas turbine engineering came directly from steam turbine design.) The main differences are the different gas density, molecular weight, isentropic expansion coefficient, and (to a lesser extent) viscosity of the two fluids. 


\subsection{Types of Steam Turbines}

Condensing turbine: The primary type of turbine used for central power generation is the condensing turbine. These power-only utility turbines exhaust low-pressure steam directly to condensers that maintain vacuum conditions at the discharge of the turbine. An array of tubes, cooled by river, lake, or cooling-tower water, condenses the steam into (liquid) water. ${ }^{2}$ The condenser vacuum is caused by the near-ambient cooling water causing condensation of the steam turbine exhaust steam in the condenser. Because small amounts of air may leak into the parts of the system that are below atmospheric pressure, a relatively small compressor is used to remove noncondensable gases from the condenser. The condensing turbine processes result in maximum power and electrical generation efficiency from the steam supply and boiler fuel. The power output of condensing turbines is sensitive to ambient conditions because the condenser temperature determines the outlet pressure of the turbine. ${ }^{3}$

Industrial-scale steam turbines used for CHP, where the turbine exhaust steam is used for other purposes, can be classified into two main types: noncondensing and extraction.

Noncondensing (Back-Pressure) Turbines: The noncondensing turbine (also referred to as a back-pressure turbine) exhausts its entire flow of steam to the industrial process or facility steam mains at conditions close to the process heat requirements, as shown in Figure 4.

Figure 4. Noncondensing (Back-Pressure) Steam Turbine

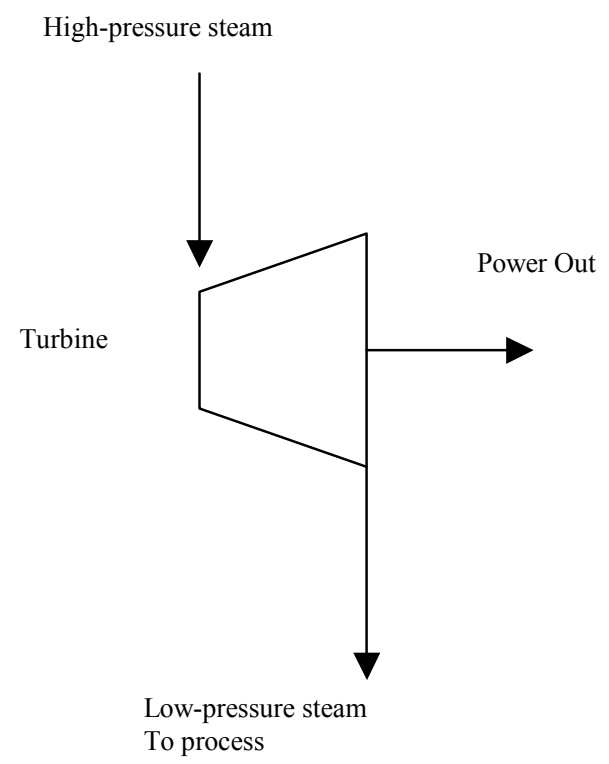

\footnotetext{
${ }^{2}$ At $80^{\circ} \mathrm{F}$, the vapor pressure of water is $0.51 \mathrm{psia}$; at $100^{\circ} \mathrm{F}$, it is $0.95 \mathrm{psia}$; at $120^{\circ} \mathrm{F}$, it is $1.69 \mathrm{psia}$; and at $140^{\circ} \mathrm{F}$, it is 2.89 psia

${ }^{3}$ From a reference condition of condensation at $100^{\circ} \mathrm{F}, 6.5 \%$ less power is obtained from the inlet steam when the temperature at which the steam is condensed is increased (because of higher temperature ambient conditions) to $115^{\circ} \mathrm{F}$. Similarly, the power output is increased by $9.5 \%$ when the condensing temperature is reduced to $80^{\circ} \mathrm{F}$. This illustrates the influence of steam turbine discharge pressure on power output and, consequently, on net heat rate (and efficiency.)
} 
Usually, the steam sent into the mains is not much above saturation temperature. ${ }^{4}$ The term "back-pressure" refers to turbines that exhaust steam at atmospheric pressures and above. The discharge pressure is established by the specific site requirements $-50,150$, and 250 psig are the most typical pressure levels for steam distribution systems. The lower pressures most often are used in district heating systems, and the higher pressures most often are used in supplying steam to industrial processes. Industrial processes often include further expansion for mechanical drives, using small steam turbines to drive heavy equipment that is intended to run continuously for long periods.

Extraction Turbines: Extraction turbines have opening(s) in their casings for extraction of a portion of the steam at some intermediate pressure. The extracted steam may be used for process purposes in a CHP facility or for feedwater heating - as is the case in most utility power plants. The rest of the steam is condensed, as illustrated in Figure 5.

\section{Figure 5. Extraction Steam Turbine}

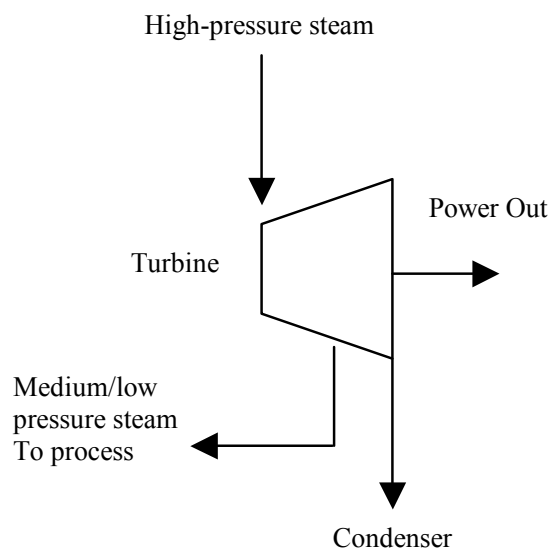

The steam-extraction pressure may or may not be automatically regulated depending on the turbine design. Regulated extraction allows more steam to flow through the turbine to generate additional electricity during periods of low thermal demand by the CHP system. In utility-type steam turbines, there may be several extraction points, each at a different pressure corresponding to a different temperature at which heat is needed in the thermodynamic cycle. The facility's specific needs for steam and power over time determine the extent to which steam will be extracted for use in the process - or be expanded to vacuum conditions and condensed.

In large, often complex, industrial plants, additional steam may be admitted into the steam turbine, flowing in through the casing and increasing the flow in the steam path. This arrangement is often used when multiple boilers are operating at different pressures, because of their historical existence. These steam turbines are referred to as admission turbines. At steamextraction and admission locations, there are usually steam flow-control valves that add to the cost of the turbine and control system.

\footnotetext{
${ }^{4}$ At $50 \mathrm{psig}$ ( $\left.65 \mathrm{psia}\right)$ the condensation temperature is $298^{\circ} \mathrm{F}$; at $150 \mathrm{psig}(165 \mathrm{psia})$, the condensation temperature is $366^{\circ} \mathrm{F}$; and at $250 \mathrm{psig}(265 \mathrm{psia})$, it is $406^{\circ} \mathrm{F}$.

Gas-Fired Distributed Energy Resource Technology Characterizations Small Steam Turbine Systems - Page 6-7
} 


\subsection{Design Characteristics}

Custom design:

Thermal output:

Fuel flexibility:

Reliability and life:

Size range:

Emissions:

Efficiency:
Steam turbines, which can be designed to match various design pressure and temperature requirements, also can be designed to maximize efficiency while providing desired thermal output.

Steam turbines are capable of operating over a very broad range of steam pressures. Utility steam turbines operate with inlet steam pressures up to 3,500 psig and exhaust vacuum conditions as low as one-half psia. Through use of backpressure or extraction steam at appropriate pressures and temperatures, steam turbines can be custom designed to meet the thermal requirements of the CHP applications.

Steam turbines can use a variety of fuels - including coal, oil, natural gas, wood, and waste products.

Steam turbine life is extremely long. There are steam turbines that have been in service for more than 50 years. In addition, overhaul intervals are measured in years. When properly operated and maintained (including proper control of boiler water chemistry), steam turbines also are extremely reliable. However, to achieve this, they require controlled thermal transients because the massive casing heats up slowly and differential expansion of the parts must be minimized to avoid damage.

Industrial steam turbines are available in sizes from less than 50 $\mathrm{kW}$ (as mentioned in the introduction) to more than $250 \mathrm{MW}$. In the multi-megawatt size range, industrial and utility steam turbine designations merge, with the same turbine (high-pressure) section able to serve either industrial or small utility applications.

Emissions depend on the fuel used by the boiler or other steam source, boiler furnace combustion section design and operation, and built-in and add-on boiler exhaust cleanup systems.

The electrical generating-cycle efficiency of steam turbine power plants varies from a high of more than $36 \% \mathrm{HHV}^{5}$ for large, electric utility plants designed for the highest practical annual

\footnotetext{
${ }^{5}$ Steam turbine power plants traditionally measure efficiency on a higher heating value (HHV) basis, as that is the basis on which solid fuels are sold. However, gas turbine and internal combustion engine manufacturers quote heat rates in terms of the lower heating value (LHV) of the fuel. In addition, electric utilities measure power plant heat rates in terms of HHV. For natural gas, the average heat content of natural gas is 1,030 Btu/scf on an HHV basis and $930 \mathrm{Btu} / \mathrm{scf}$ on an LHV basis - or about a 10\% difference. The difference between the HHV and LHV is the heat of condensation of the water vapor in the combustion products.
} 
capacity factor, to less than $10 \%$ HHV for small, simple plants that make electricity as a byproduct of delivering steam to industrial processes or to district heating systems for colleges, industrial parks, and building complexes.

\subsection{Cost and Performance Characteristics}

This section describes the cost and performance of on-site steam turbine systems.

\subsection{System Performance}

Table 1 summarizes the performance characteristics of "typical" commercially available steam turbine systems and for boiler/steam CHP systems in the $500 \mathrm{~kW}$ to $15 \mathrm{MW}$ size range. Steam turbine thermodynamic efficiency (isentropic efficiency) refers to the ratio of power actually generated from the steam turbine, compared to what would be generated by a perfect turbine (with no internal losses or heat losses to the environment) using steam at the same inlet conditions and discharging to the same downstream pressure. Steam turbine thermodynamic efficiency - which is a measure of how efficiently the turbine extracts power from the steam - is useful in identifying the conditions of the steam as it exhausts from the turbine and in comparing the performance of various steam turbines. Turbine thermodynamic efficiency is not to be confused with electrical generating efficiency, which is the ratio of net power generated to total fuel input to the cycle. Multistage (moderate to high-pressure ratio) steam turbines have thermodynamic efficiencies that range from less than $60 \%$ for very small $(<1,000 \mathrm{~kW})$ units to more than $90 \%$ for large industrial and utility-sized units. Small, single-stage steam turbines can have efficiencies as low as $50 \%$.

Steam turbine CHP systems are generally characterized by very low power-to-heat ratios, typically in the 0.05 to 0.2 range. This is because electricity is a byproduct of heat generation, with the system optimized for steam production. While steam turbine CHP system cycle electrical efficiency ${ }^{6}$ may seem very low, it is because the primary objective of a boiler/steam turbine CHP system is to produce large amounts of steam for uses other than power generation. The effective electrical efficiency ${ }^{7}$ of steam turbine systems themselves, however, is generally very high, because almost all the energy difference between the high-pressure boiler output and the low-pressure turbine output is converted to electricity. This means that total CHP system efficiencies $^{8}$ are generally very high and approach the boiler efficiency level. Steam boiler efficiencies range from $70 \%$ to $85 \%$ HHV depending on boiler type and age, fuel, duty cycle, application, and steam conditions.

Equipment and installed cost estimates in Table 1 are based on retrofit applications of steam turbines into existing boiler/steam systems. Only the capital and installation costs of the steam turbine, its generator, controls, and electrical interconnection are considered, with the balance of plant already in place.

\footnotetext{
${ }^{6}$ Net power output/total fuel input into the system.

${ }^{7}$ (Steam turbine electric power output)/(total fuel input to boiler - (steam to process/boiler efficiency)).

${ }^{8}$ Net power and steam generated as a fraction of total fuel input. Gas-Fired Distributed Energy Resource Technology Characterizations Small Steam Turbine Systems - Page 6-9
} 
Table 1. Boiler/Steam Turbine Systems - Typical Performance Parameters (2003)

\begin{tabular}{|c|c|c|c|}
\hline Cost and Performance Characteristics ${ }^{9}$ & System 1 & System 2 & System 3 \\
\hline Nominal Capacity (kW) & 500 & 3,000 & 15,000 \\
\hline \multicolumn{4}{|l|}{ Steam Turbine Characteristics } \\
\hline Turbine Type & Back Pressure & Back Pressure & Back Pressure \\
\hline Typical Application & Chemical plant & Paper mill & Paper mill \\
\hline Equipment Cost $(2003 \$ / \mathrm{kW})^{10}$ & 540 & 225 & 205 \\
\hline Total Installed Cost $(2003 \$ / \mathrm{kW})^{11}$ & 918 & 385 & 349 \\
\hline Turbine Isentropic Efficiency $(\%)^{12}$ & 50 & 70 & 80 \\
\hline Generator/Gearbox Efficiency (\%) & 94 & 94 & 97 \\
\hline Input Steam Flow (lbs/hr) & 21,500 & 126,000 & 450,000 \\
\hline Inlet Pressure (psig) & 500 & 600 & 700 \\
\hline Inlet Temperature $\left({ }^{\circ} \mathrm{F}\right)$ & 550 & 575 & 650 \\
\hline Outlet Pressure (psig) & 50 & 150 & 150 \\
\hline Outlet Temperature $\left({ }^{\circ} \mathrm{F}\right)$ & 298 & 366 & 366 \\
\hline \multicolumn{4}{|l|}{ CHP Characteristics* } \\
\hline Electricity/Fuel Ratio & 0.06 & 0.07 & 0.09 \\
\hline Boiler Efficiency (\%), HHV & 80 & 80 & 80 \\
\hline Effective Electrical Efficiency (\%), HHV ${ }^{13}$ & 75.6 & 75.1 & 77.8 \\
\hline Cycle Electric Efficiency (\%), HHV ${ }^{14}$ & 6.4 & 6.9 & 9.3 \\
\hline Fuel Input (MMBtu/hr) $)^{15}$ & 26.7 & 147.4 & 549.0 \\
\hline Steam to Process (MMBtu/hr) & 19.6 & 107.0 & 386.6 \\
\hline Steam to Process (kW) & 5,740 & 31,352 & 113,291 \\
\hline Total CHP Efficiency (\%), HHV ${ }^{16}$ & 79.6 & 79.5 & 79.7 \\
\hline Heat/Fuel Ratio ${ }^{17}$ & 0.73 & 0.72 & 0.70 \\
\hline Power/Heat Ratio ${ }^{18}$ & 0.09 & 0.10 & 0.13 \\
\hline Net Heat Rate $(\mathrm{Btu} / \mathrm{kWh})^{19}$ & 4,515 & 4,568 & 4,388 \\
\hline
\end{tabular}

*CHP Characteristics are based on output of a boiler/steam turbine system

\footnotetext{
${ }^{9}$ Characteristics for "typical" commercially available steam turbine generator systems in 2003. Steam turbine data based on information from: TurboSteam, Inc., for $500 \mathrm{~kW}$ and $3 \mathrm{MW}$; General Electric for $15 \mathrm{MW}$ turbine.

${ }^{10}$ Equipment cost includes turbine, gearbox, generator, controls, and switchgear; boiler and steam system costs are not included.

${ }^{11}$ Installed costs vary greatly based on site-specific conditions; installed costs of a "typical" simple installation were estimated to be $70 \%$ of the equipment costs. Boiler and steam system costs are not included.

${ }^{12}$ The isentropic efficiency of a turbine is a comparison of the actual power output compared to the ideal - or isentropic - output. It is a measure of the effectiveness of extracting work from the expansion process and is used to determine the outlet conditions of the steam from the turbine.

${ }^{13}$ Effective Electrical Efficiency $=($ Steam turbine electric power output $) /($ Total fuel into boiler - (steam to process/boiler efficiency)). Perfect conversion from heat to power would be $3,412 \mathrm{Btu} / \mathrm{kWh}$.

${ }^{14}$ Cycle electrical efficiency $=$ Net electricity generated/total fuel input to boiler. It is a measure of the amount of boiler fuel converted into electricity.

${ }^{15}$ Fuel input based on condensate return at steam outlet pressure and saturation temperature.

${ }^{16}$ Total CHP efficiency $=($ net electricity generated + net steam to process $) /$ total fuel input to boiler.

${ }^{17}$ Heat/Fuel Ratio $=$ Thermal output (total heat recovered $($ MMBtu/hr) $/$ fuel input $(M M B t u / h r)$.

${ }^{18}$ Power/Heat Ratio $=$ CHP electric power output $($ Btu equivalent $) /$ useful thermal output $($ Btu).

${ }^{19}$ Net Heat Rate $=($ total fuel input to the boiler - the fuel that would be required to generate the steam to process assuming the same boiler efficiency)/steam turbine electric output (kW).
}

Gas-Fired Distributed Energy Resource Technology Characterizations

Small Steam Turbine Systems - Page 6-10 


\subsection{Combined Heat and Power Performance}

The amount and quality of steam available for process use after passing through the steam turbine is a function of the entering steam conditions and the design of the steam turbine. Exhaust steam from the turbine can be used directly in a process or for district heating. It can also be converted to other forms of thermal energy, including hot or chilled water. Steam discharged or extracted from a steam turbine could be used in a single- or double-effect absorption chiller. The steam turbine also could be used as a mechanical drive for a centrifugal chiller.

Between the power-only output of a condensing steam turbine and the power and steam combination of a back-pressure steam turbine, essentially any ratio of power to heat output can be supplied to a facility. Back-pressure steam turbines can be obtained with a variety of back pressures, further increasing the variability of the power-to-heat ratio. This flexibility gives system designers the ability to create CHP systems that respond to seasonal and daily variations in power and steam demands.

\subsection{Performance and Efficiency Enhancements}

There are numerous steam turbine design features that have been implemented to increase efficiency, allow operation over a range of conditions, simplify manufacture and repair, and achieve other practical purposes. The long history of steam turbine use has resulted in a large inventory of steam turbine designs that can be used to tailor turbines for specific applications. Manufacturers tailor design requirements by varying the flow area in the internal turbine stages and the extent to which steam is extracted (removed from the flow path between stages) to accommodate the specifications of their clients.

Because steam turbine casings are thick, to enable them to handle high steam pressures, they have high thermal inertia. Steam turbines must be warmed and cooled slowly to minimize the differential expansion between the rotating blades and the stationary parts. Large steam turbines may need more than 10 hours to warm up safely. While smaller units have more-rapid start-up times, steam turbines differ appreciably from reciprocating engines, which can start up rapidly. They also differ from gas turbines, which can start in a moderate amount of time and load-follow with reasonable rapidity.

Steam turbines usually operate continuously for extended periods of time, even though the steam fed to the unit and the power delivered may vary (slowly) during such periods of continuous operation. As most steam turbines are selected for applications with high duty factors, they only need to respond to slow temperature changes during operation, and can usually tolerate their long start-up times.

When the steam is expanded through a high-pressure-ratio turbine - as in utility and large industrial steam systems - the steam can begin to condense in the turbine if the temperature drops below the saturation temperature at that pressure. If water droplets are allowed to form in 
the turbine, blade erosion will occur when the drops impacted the blades. To avoid this, at this point in the expansion, the steam is sometimes returned to the boiler and reheated to high temperature and then returned to the turbine for further (safe) expansion. In a few very large, high-pressure, utility steam systems, double reheat systems are installed.

\subsection{Capital Cost}

Steam turbine-based CHP plants are complex, with many interrelated subsystems that usually must be custom designed. The cost of complete solid-fuel CHP plants depends on many factors, including major cost items, such as fuels handling, pollution-control equipment, and boilers. A typical breakdown of installed costs for a complete steam turbine CHP plant is boiler (25\%); fuel handling, storage, and preparation system (25\%); stack gas cleanup and pollution controls (20\%); steam turbine generator (15\%); and field construction and plant engineering (15\%). Because of both the size of such plants and the diverse sources of the components, solid fuel cogeneration plants invariably involve extensive system engineering and field labor during construction. Typical complete plants cost more than $\$ 1,000 / \mathrm{kW}$, with little generalization; although, for the same fuel and configuration, costs per $\mathrm{kW}$ of capacity generally increase as size decreases. ${ }^{20}$ Because of the fuel- and site-specific nature of boiler costs, Table 1 includes equipment and installation costs for the steam turbine and generator system only.

Steam turbine prices depend greatly on the extent of competition and related manufacturing volumes for units of desired size, inlet and exit steam conditions, rotational speed, and standardization of construction. Prices are usually quoted for an assembled steam turbineelectrical generator package. The electrical generator can account for $20 \%$ to $40 \%$ of the cost of the turbine-generator assembly. Because steam turbine/electrical generator packages are heavydue in large part to the heavy walled construction of the high-pressure turbine casing - they must be mounted on appropriate pedestals. The installation and connection to the boiler through high pressure-high temperature steam pipes requires specialized engineering and installation expertise. Should the turbine have variable extraction, the cost of the extraction valve and control system adds to the installation.

Steam turbines are made in sizes with finite steps between the sizes. The cost of the turbine is generally the same for the upper and lower limit of the steam flowing through it, so step-like behavior is sometimes seen in steam turbine prices. Because they come in specific size increments, steam turbines that are used at the upper end of their power capability cost less per $\mathrm{kW}$ generated than those used at the lower end of their capability. Additionally, raw material cost, local labor rates, delivery times, availability of existing major components, and similar business conditions can affect steam turbine pricing. Prices per $\mathrm{kW}$ for steam turbines are higher for smaller turbines, ranging from more than $\$ 500 / \mathrm{kW}$ (turbine only) for a $500 \mathrm{~kW}$ back-pressure turbine to approximately $\$ 200 / \mathrm{kW}$ for a $15 \mathrm{MW}$ back-pressure turbine. ${ }^{21}$

\footnotetext{
${ }^{20}$ Spiewak, Scott A. and Larry Weiss, Cogeneration \& Small Power Production Manual, fifth edition. Fairmont Press, Wilburn, GA, 1997: pages 82 and 95. These figures are for a $32.3 \mathrm{MW}$ multifuel-fired, 1,250 psig, $900^{\circ} \mathrm{F}$, 50 psig back-pressure steam turbine used in an industrial cogeneration plant.

${ }^{21}$ Based on discussions with TurboSteam (500 kW and $3 \mathrm{MW}$ ) and General Electric (15 MW). Gas-Fired Distributed Energy Resource Technology Characterizations Small Steam Turbine Systems - Page 6-12
} 


\subsection{Maintenance}

Steam turbines are rugged, with operational life often exceeding 50 years. Maintenance is simple, comprised mainly of ensuring that all fluids (steam flowing through the turbine and the oil for the bearing) are always clean and at the proper temperature. Other maintenance activities include inspecting auxiliaries such as lubricating-oil pumps, coolers, and oil strainers; and checking the operation of safety devices such as overspeed trips.

In order to obtain reliable service, steam turbines require long warm-up periods so that there are minimal thermal expansion stress and wear concerns. Steam turbine maintenance costs are quite low, typically less than $\$ 0.004$ per $\mathrm{kWh}$. Boilers and any associated solid-fuel processing and handling equipment that is part of the boiler/steam turbine plant require their own types of maintenance.

One maintenance issue with steam turbines is the removal of solids that carry over from the boiler and deposit on turbine nozzles and other internal parts, degrading turbine efficiency and power output. Some of these solids are water-soluble, but others are not. Three methods are employed to remove deposits: 1) manual removal; 2) cracking off the deposits by shutting off the turbine and allowing it to cool; and 3) water-washing water-soluble deposits while the turbine is running.

\subsection{Fuels}

Industrial boilers operate on a wide variety of fuels, including wood, coal, natural gas, oils (including residual oil - the left-over material when the valuable distillates have been separated for separate sale), municipal solid waste, and sludges. The fuel handling, storage, and preparation equipment needed for solid fuels adds considerably to the cost of an installation. Thus, such fuels are used only when a high annual capacity factor is expected of the facility, or when the solid material has to be disposed of to avoid an environmental or space occupancy problem.

\subsection{Availability and Life}

Steam turbines are generally considered to have 99\%-plus availability with longer than one year between shutdowns for maintenance and inspections. This high level of availability applies only to the steam turbine, not to the boiler or HRSG that is supplying the steam.

The service life of steam turbines can be extremely long with proper maintenance and adequate water conditioning. There are examples of steam turbines that have been in service for more than 50 years. For comparative purposes, the economic life of steam turbine systems may be assumed to be a minimum of 20 years. 


\subsection{Emission Characteristics}

Emissions associated with a steam turbine are dependent on the fuel used to generate the steam. Steam turbines can be used with a boiler firing any one or a combination of a large variety of fuels, or they can be used with a gas turbine in a combined-cycle configuration. Boiler emissions vary depending on fuel type, boiler design, environmental conditions, and pollution-control technologies. Boiler emissions include nitrogen oxides $\left(\mathrm{NO}_{\mathrm{x}}\right)$, sulfur oxides $\left(\mathrm{SO}_{\mathrm{x}}\right)$, particulate matter $(\mathrm{PM})$, carbon monoxide $(\mathrm{CO})$, and carbon dioxide $\left(\mathrm{CO}_{2}\right)$.

\subsection{Control Options}

$\mathrm{NO}_{\mathrm{x}}$ control has been the primary focus of emissions-control research and development in boilers. The following provides a description of the most prominent emissions-control approaches.

\section{Combustion Process Emissions Control:}

Combustion-control techniques are less costly than post-combustion control methods and are often used on industrial boilers for $\mathrm{NO}_{\mathrm{x}}$ control. Control of combustion temperature has been the principal focus of combustion process control in boilers. Combustion control requires tradeoffs - high temperatures favor complete combustion of the fuel and low residual hydrocarbons and $\mathrm{CO}$, but high temperatures promote $\mathrm{NO}_{\mathrm{x}}$ formation. Lean combustion dilutes the combustion process and reduces combustion temperatures and $\mathrm{NO}_{\mathrm{x}}$ formation. However, lean combustion undesirably reduces boiler efficiency.

Flue-Gas Recirculation (FGR):

FGR is the most effective technique for reducing $\mathrm{NO}_{\mathrm{x}}$ emissions from industrial boilers with inputs below $100 \mathrm{MMBtu} / \mathrm{hr}$. With FGR, a portion of the relatively cool boiler exhaust gases reenters the combustion process, reducing the flame temperature and associated thermal $\mathrm{NO}_{\mathrm{x}}$ formation. It is the most popular and effective $\mathrm{NO}_{\mathrm{x}}$ reduction method for firetube and watertube boilers, and many installations can rely solely on FGR to meet environmental standards.

External FGR employs a fan to recirculate the flue gases into the flame, with external piping carrying the gases from the stack to the burner. A valve responding to boiler input controls the recirculation rate. Induced FGR relies on the combustion air fan for flue-gas recirculation. A portion of the gases travel via ductwork or internally to the air fan, where they are premixed with combustion air and introduced into the flame through the burner. Induced FGR in newer designs utilize an integral design that is relatively uncomplicated and reliable. The practical limit to $\mathrm{NO}_{\mathrm{x}}$ reduction via FGR is $80 \%$ in natural gas-fired boilers and $25 \%$ for standard fuel oils.

Low Excess Air Firing (LAE):

High levels of excess air can result in increased $\mathrm{NO}_{\mathrm{x}}$ formation, because the excess nitrogen and oxygen in the combustion air entering the flame combine to form thermal $\mathrm{NO}_{\mathrm{x}}$. Firing with low excess air means limiting the excess air that enters the combustion process, thus limiting the amount of extra nitrogen and oxygen entering the flame. This is accomplished through burner 
design modification and is optimized through the use of oxygen trim controls. When operating with low excess air, care must be taken to accomplish complete combustion of the fuel and to avoid excess $\mathrm{CO}$ emissions. LAE can result in overall $\mathrm{NO}_{\mathrm{x}}$ reductions of $5 \%$ to $10 \%$ when firing with natural gas. In small, compact oil- and gas-fired boilers, high levels of excess air are frequently used to ensure complete combustion. Large industrial boilers usually use low excess air in order to minimize the heat loss in the stack exhaust.

\section{Low-Nitrogen Fuel Oil:}

$\mathrm{NO}_{\mathrm{x}}$ formed by fuel-bound nitrogen can account for $20 \%$ to $50 \%$ of total $\mathrm{NO}_{\mathrm{x}}$ levels in oil-fired boiler emissions. The use of low-nitrogen fuels in boilers firing distillate oils is one method of reducing $\mathrm{NO}_{\mathrm{x}}$ emissions. Such low-nitrogen fuels can contain significantly less fuel-bound nitrogen than other fuels. $\mathrm{NO}_{\mathrm{x}}$ levels up to $70 \%$ lower than $\mathrm{NO}_{\mathrm{x}}$ emissions from standard No. 2 oils have been achieved in firetube boilers by utilizing flue-gas recirculation.

\section{Burner Modifications:}

By modifying the design of standard burners to create larger flames, lower-flame temperatures and lower-thermal $\mathrm{NO}_{\mathrm{x}}$ formation can be achieved, resulting in lower overall $\mathrm{NO}_{\mathrm{x}}$ emissions. While most boiler types and sizes can accommodate burner modifications, such modifications are most effective for boilers firing natural gas and distillate fuel oils, with little effectiveness in heavy oil-fired boilers. Also, burner modifications must be complemented with other $\mathrm{NO}_{\mathrm{x}}$ reduction methods, such as flue-gas recirculation, to comply with the more stringent environmental regulations. Achieving low $\mathrm{NO}_{\mathrm{x}}$ levels $(30 \mathrm{ppm})$ through burner modification alone can adversely impact boiler-operating parameters such as turndown, capacity, CO levels, and efficiency.

\section{Water/Steam Injection:}

Injecting water or steam into flames reduces flame temperature, lowering thermal $\mathrm{NO}_{\mathrm{x}}$ formation and overall $\mathrm{NO}_{\mathrm{x}}$ emissions. However, under normal operating conditions, water/steam injection can decrease boiler efficiency by $3 \%$ to $10 \%$. Also, there is a practical limit to the amount that can be injected without causing condensation-related problems. This method is often employed in conjunction with other $\mathrm{NO}_{\mathrm{x}}$-control techniques such as burner modifications or flue-gas recirculation. When used with natural gas-fired boilers, water/steam injection can decrease $\mathrm{NO}_{\mathrm{x}}$ emission by up to $80 \%$, with less reduction achievable in oil-fired boilers.

\section{Post-Combustion Emissions Control}

There are several types of exhaust-gas treatment processes that are applicable to industrial boilers.

\section{Selective Non-Catalytic Reduction (SNCR):}

In boiler SNCR, a $\mathrm{NO}_{\mathrm{x}}$-reducing agent such as ammonia or urea is injected into the boiler exhaust gases at a temperature in the 1400 to $1600^{\circ} \mathrm{F}$ range. The agent breaks down the $\mathrm{NO}_{\mathrm{x}}$ in the exhaust gases into water and atmospheric nitrogen $\left(\mathrm{N}_{2}\right)$. While SNCR can decrease boiler $\mathrm{NO}_{\mathrm{x}}$ emissions by up to $70 \%$, it is very difficult to apply SNCR industrial boilers that modulate or cycle frequently. To perform properly, the reducing agent must be introduced at a specific flue-gas temperature, and the location of the exhaust gases at the necessary temperature is constantly changing in a cycling boiler. 
Selective Catalytic Reduction (SCR):

This technology involves the injection of the reducing agent into the boiler exhaust gas in the presence of a catalyst. The catalyst allows the reducing agent to operate at lower exhaust temperatures than SNCR, in the 500 to $1200^{\circ} \mathrm{F}$ temperature range. Depending on the type of catalyst, $\mathrm{NO}_{\mathrm{x}}$ reductions of up to $90 \%$ are achievable with SCR. The two agents used commercially are ammonia $\left(\mathrm{NH}_{3}\right.$ in anhydrous liquid form or aqueous solution) and aqueous urea. Urea decomposes in the hot exhaust gas and SCR reactor, releasing ammonia. Approximately 0.9 to 1.0 moles of ammonia are required per mole of $\mathrm{NO}_{\mathrm{x}}$ at the SCR reactor inlet in order to achieve $80 \%$ to $90 \% \mathrm{NO}_{\mathrm{x}}$ reduction.

The use of SCR adds to both the system capital and operating costs, and SCR can only occasionally be justified on boilers with inputs less than $100 \mathrm{MMBtu} / \mathrm{hr}$. SCR requires on-site storage of ammonia, a hazardous chemical. In addition, ammonia can "slip" through the process unreacted, contributing to environmental health concerns.

\subsection{System Emissions}

Table 2 illustrates typical emissions of $\mathrm{NO}_{\mathrm{x}}, \mathrm{PM}$, and $\mathrm{CO}$ for boilers, by size of steam turbine system and by fuel type.

Table 2. Typical Boiler Emissions Ranges (for typical steam turbine electrical capacities)

\begin{tabular}{|l|c|c|c|c|c|c|}
\hline \multirow{2}{*}{ Boiler Fuel } & \multicolumn{3}{|c|}{$\begin{array}{c}\text { System 1 } \\
\mathbf{5 0 0} \mathbf{~ k W}\end{array}$} & \multicolumn{3}{c|}{ Systems 2 and 3 } \\
& $\mathrm{NO}_{\mathrm{x}}$ & $\mathrm{CO}$ & $\mathrm{PM}$ & $\mathrm{NO}_{\mathrm{x}}$ & $\mathrm{CO}$ & $\mathrm{PM}$ \\
\cline { 2 - 7 } & $\mathrm{N} / \mathrm{A}$ & $\mathrm{N} / \mathrm{A}$ & $\mathrm{N} / \mathrm{A}$ & $0.20-1.24$ & $0.02-0.7$ & $<0.30$ \\
\hline $\begin{array}{l}\text { Coal } \\
(\mathrm{lbs} / \mathrm{MMBtu})\end{array}$ & $0.22-0.49$ & 0.6 & $0.33-0.56$ & $0.22-0.49$ & 0.06 & $0.33-0.56$ \\
\hline $\begin{array}{l}\text { Wood } \\
(\mathrm{lbs} / \text { MMBtu) }\end{array}$ & $0.15-0.37$ & 0.03 & $0.01-0.08$ & $0.07-0.31$ & 0.03 & $0.01-0.08$ \\
\hline $\begin{array}{l}\text { Fuel Oil } \\
(\text { lbs/MMBtu) }\end{array}$ & $0.03-0.1$ & 0.08 & - & $0.1-0.28$ & 0.08 & - \\
\hline $\begin{array}{l}\text { Natural Gas } \\
(\mathrm{lbs} / \text { MMBtu) }\end{array}$ & & & & & & \\
\hline
\end{tabular}

Note: All emissions values are without post-combustion treatment.

Source: EPA, "Compilation of Air Pollutant Emission Factors," AP-42, Fifth Edition, Volume I: Stationary Point and Area Sources.

\subsection{Key Technology Objectives}

Steam turbine technology performance has advanced little in recent years. This is because the technology was invented more than 100 years ago and has been steadily improving since that time. Improvements have been (slowly) made in cost reduction, component standardization, 
reliability, and maintainability - which are of high value to steam turbine owners. The steam path losses that have been the focus of improvement efforts over the past decades fall into four major groups. These are: 1) the losses associated with the geometry of the steam path components and their spatial arrangement; 2) losses resulting from the effects of water in the steam; 3) losses caused by the exhaust energy of the steam leaving the last-stage blades; and 4) losses associated with steam leakage, and steam bypassing the blade rows. ${ }^{22}$ Progress in these areas is being made through a series of small, slow advances.

Relatively recent advances in large industrial and utility steam turbines include barrel-type casings for enhanced thermal loading, reduced radial and axial clearances for higher efficiency, and computer-optimized blade designs. Three-dimensional modeling has allowed new approaches to shaping steam paths and use of twisted, leaned, and curved vanes and blades in all sections of the turbines. New materials that are less susceptible to corrosion have been incorporated into rotors, casings, and discs in the low-pressure region; and many of the seals in the system have been improved. Many of these advances eventually will be incorporated into smaller steam turbine designs at a pace that will depend on market activity.

The most significant advance that could occur in small steam turbine systems for distributed generation/distributed resources would be increased manufacturing volumes leading to commensurate reductions in cost and reduced lead time from order to delivery.

\subsection{Advanced Technology Projections}

Estimates of the future performance of the three steam turbine-based CHP systems previously characterized as "representative systems" in Table 1 are shown in Table 3. Steam turbines are a mature technology, and projected advances will be largely evolutionary in nature. The out-year performance projections for 2010, 2020, and 2030 reflect minor enhancements in reliability and minor reductions in cost. They also reflect eventual adaptation of advances made in large industrial/utility steam turbines systems to smaller CHP steam turbine systems. The projections are based on discussions with turbine manufacturers and system packagers.

\footnotetext{
${ }^{22}$ Sanders, William P. and Mitola, Anthony F., "Energy Losses within the Turbine Steam Path," page 20, International Turbomachinery, January/February 2002, Vol. 43 No.1, Norwalk, Connecticut. 
Table 3. Current and Advanced Steam Turbine System Characteristics ${ }^{23,24}$

\begin{tabular}{|c|c|c|c|c|}
\hline \multicolumn{5}{|c|}{$\begin{array}{l}\text { Cost and Performance Projections, } \\
500 \text { kW Back-pressure Steam Turbine CHP System }\end{array}$} \\
\hline Year & Current & 2010 & 2020 & 2030 \\
\hline \multicolumn{5}{|l|}{ Steam Turbine Parameters } \\
\hline Equipment Cost $(2003 \$ / \mathrm{kW})$ & 540 & 516 & 498 & 481 \\
\hline Total Installed Cost $(2003 \$ / \mathrm{kW})$ & 918 & 878 & 847 & 819 \\
\hline Isentropic Efficiency (\%) & 50 & 52 & 54 & 56 \\
\hline Turbine/Generator Efficiency (\%) & 94 & 94 & 94 & 94 \\
\hline Steam Flow (lbs/hr) & 21,500 & 20,555 & 19,840 & 19,170 \\
\hline Inlet Pressure (psig) & 500 & 500 & 500 & 500 \\
\hline Inlet Temperature $\left({ }^{\circ} \mathrm{F}\right)$ & 550 & 550 & 550 & 550 \\
\hline Outlet Pressure (psig) & 50 & 50 & 50 & 50 \\
\hline Outlet Temperature $\left({ }^{\circ} \mathrm{F}\right)$ & 298 & 298 & 298 & 298 \\
\hline \multicolumn{5}{|l|}{ CHP Parameters } \\
\hline Total CHP Efficiency (\%) & 79.6 & 79.7 & 79.6 & 79.6 \\
\hline Fuel Input (MMBtu/hr) & 26.7 & 25.6 & 24.7 & 23.8 \\
\hline Steam to Process (MMBtu/hr) & 19.6 & 18.7 & 17.9 & 17.3 \\
\hline Steam to Process $(\mathrm{kW})$ & 5,740 & 5,470 & 5,257 & 5,062 \\
\hline Inlet Enthalpy (Btu/lb) & 1,265 & 1,265 & 1,265 & 1,265 \\
\hline Exhaust Enthalpy (Btu/lb) & 1,181 & 1,178 & 1,174 & 1,171 \\
\hline Cycle Heat Rate (Btu/kWh), HHV & 53,481 & 51,131 & 49,352 & 47,685 \\
\hline Cycle Electric Efficiency (\%) & 6.4 & 6.7 & 6.9 & 7.2 \\
\hline Power/Heat Ratio & 0.09 & 0.09 & 0.10 & 0.10 \\
\hline Net Heat Rate $(\mathrm{Btu} / \mathrm{kWh})$ & 4,515 & 4,471 & 4,514 & 4,505 \\
\hline Effective Electrical Efficiency (\%) & 75.6 & 76.3 & 75.6 & 75.8 \\
\hline Heat/Fuel Ratio & 0.73 & 0.73 & 0.73 & 0.72 \\
\hline Electricity/Fuel Ratio & 0.06 & 0.07 & 0.07 & 0.07 \\
\hline
\end{tabular}

Source: Energy and Environmental Analysis, Inc., internal estimates

\footnotetext{
${ }^{23}$ The base case $500 \mathrm{~kW}$ and $3 \mathrm{MW}$ steam turbine system data is based on information from TurboSteam, Inc. The base case $15 \mathrm{MW}$ steam turbine system data is based on information from General Electric. The advanced cases are based on the incorporation of minor enhancements in reliability and minor reductions in cost, and reflect some adaptation of advances made in large industrial/utility systems to CHP steam turbine systems.

${ }^{24}$ Boiler efficiency of $80 \%$ assumed throughout.
}

Gas-Fired Distributed Energy Resource Technology Characterizations Small Steam Turbine Systems - Page 6-18 
Table 3 (cont'd.) Current and Advanced Steam Turbine System Characteristics

\begin{tabular}{|c|c|c|c|c|}
\hline \multicolumn{5}{|c|}{$\begin{array}{l}\text { Cost and Performance Projections, } \\
\text { 3,000 kW Back-pressure Steam Turbine CHP System }\end{array}$} \\
\hline Year & Current & 2010 & 2020 & 2030 \\
\hline \multicolumn{5}{|l|}{ Steam Turbine Parameters } \\
\hline Equipment Cost $(2003 \$ / \mathrm{kW})$ & 225 & 221 & 220 & 214 \\
\hline Total Installed Cost $(2003 \$ / \mathrm{kW})$ & 385 & 376 & 373 & 364 \\
\hline Isentropic Efficiency $(\%)$ & 70 & 71 & 72 & 73 \\
\hline Turbine/Generator Efficiency (\%) & 94 & 94 & 94 & 94 \\
\hline Steam Flow (lbs/hr) & 126,000 & 124,000 & 123,000 & 120,000 \\
\hline Inlet Pressure (psig) & 600 & 600 & 600 & 600 \\
\hline Inlet Temperature $\left({ }^{\circ} \mathrm{F}\right)$ & 575 & 575 & 575 & 575 \\
\hline Outlet Pressure (psig) & 150 & 150 & 150 & 150 \\
\hline Outlet Temperature $\left({ }^{\circ} \mathrm{F}\right)$ & 366 & 366 & 366 & 366 \\
\hline \multicolumn{5}{|l|}{ CHP Characteristics } \\
\hline Total CHP Efficiency (\%) & 79.5 & 79.5 & 79.5 & 79.5 \\
\hline Fuel Input (MMBtu/h) & 147.4 & 145.1 & 143.9 & 140.4 \\
\hline Steam to Process $(\mathrm{MMBtu} / \mathrm{h})$ & 107.0 & 105.2 & 104.2 & 101.4 \\
\hline Steam to Process $(\mathrm{kW})$ & 31,352 & 30,818 & 30,534 & 29,719 \\
\hline Inlet Enthalpy (Btu/lb) & 1,272 & 1,272 & 1,272 & 1,272 \\
\hline Exhaust Enthalpy (Btu/lb) & 1,185 & 1,184 & 1,183 & 1,181 \\
\hline Cycle Heat Rate (Btu/kWh), HHV & 49,140 & 48,360 & 47,970 & 46,800 \\
\hline Cycle Electric Efficiency (\%) & 6.9 & 7.1 & 7.1 & 7.3 \\
\hline Power/Heat Ratio & 0.10 & 0.10 & 0.10 & 0.10 \\
\hline Net Heat Rate (Btu/kWh) & 4,568 & 4,547 & 4,561 & 4,550 \\
\hline Effective Electrical Efficiency (\%) & 75.1 & 75.1 & 74.8 & 75.0 \\
\hline Heat/Fuel Ratio & 0.73 & 0.72 & 0.72 & 0.72 \\
\hline Electricity/Fuel Ratio & 0.06 & 0.07 & 0.07 & 0.07 \\
\hline
\end{tabular}

Source: Energy and Environmental Analysis, Inc., estimates 
Table 3 (cont'd.) Current and Advanced Steam Turbine System Characteristics

\begin{tabular}{|c|c|c|c|c|}
\hline \multicolumn{5}{|c|}{$\begin{array}{l}\text { Cost and Performance Projections, } \\
15,000 \text { kW Back-pressure Steam Turbine CHP System }\end{array}$} \\
\hline Year & Current & 2010 & 2020 & 2030 \\
\hline \multicolumn{5}{|l|}{ Steam Turbine Parameters } \\
\hline Equipment Cost $(2003 \$ / \mathrm{kW})$ & 205 & 205 & 205 & 205 \\
\hline Total Installed Cost $(2003 \$ / \mathrm{kW})$ & 349 & 349 & 349 & 349 \\
\hline Isentropic Efficiency (\%) & 80 & 80 & 81 & 81 \\
\hline Turbine/Generator Efficiency (\%) & 97 & 97 & 97 & 97 \\
\hline Steam Flow (lbs/hr) & 450,000 & 450,000 & 434,000 & 434,000 \\
\hline Inlet Pressure (psig) & 700 & 700 & 700 & 700 \\
\hline Inlet Temperature $\left({ }^{\circ} \mathrm{F}\right)$ & 650 & 650 & 650 & 650 \\
\hline Outlet Pressure (psig) & 150 & 150 & 150 & 150 \\
\hline Outlet Temperature $\left({ }^{\circ} \mathrm{F}\right)$ & 366 & 366 & 366 & 366 \\
\hline \multicolumn{5}{|l|}{ CHP Characteristics } \\
\hline Total CHP Efficiency (\%) & 79.7 & 79.7 & 79.8 & 79.8 \\
\hline Fuel Input (MMBtu/h) & 549.0 & 549.0 & 529.5 & 529.5 \\
\hline Steam to Process (MMBtu/h) & 386.6 & 386.6 & 371.5 & 371.5 \\
\hline Steam to Process $(\mathrm{kW})$ & 113,291 & 113,291 & 108,882 & 108,882 \\
\hline Inlet Enthalpy (Btu/lb) & 1,312 & 1,312 & 1,312 & 1,312 \\
\hline Exhaust Enthalpy (Btu/lb) & 1,195 & 1,195 & 1,192 & 1,192 \\
\hline Cycle Heat Rate (Btu/kWh), HHV & 36,600 & 36,600 & 35,299 & 35,299 \\
\hline Cycle Electric Efficiency (\%) & 9.3 & 9.3 & 9.7 & 9.7 \\
\hline Power/Heat Ratio & 0.13 & 0.13 & 0.14 & 0.14 \\
\hline Net Heat Rate (Btu/kWh) & 4,388 & 4,388 & 4,340 & 4,340 \\
\hline Effective Electrical Efficiency (\%) & 77.8 & 77.8 & 78.6 & 78.6 \\
\hline Heat/ Fuel Ratio & 0.70 & 0.70 & 0.70 & 0.70 \\
\hline Electricity/Fuel Ratio & 0.09 & 0.09 & 0.10 & 0.10 \\
\hline
\end{tabular}

Source: Energy and Environmental Analysis, Inc., estimates 


\section{Financial Evaluations}

\subsection{Introduction}

This chapter provides estimates of the levelized Cost of Energy (COE) for each of the gas-fired distributed technologies. These COEs were calculated using a simplified cash flow methodology based on the FATE2-P (Financial Analysis Tool for Electric Energy Projects) spreadsheet model. This spreadsheet model was developed for the U.S. Department of Energy (DOE) and the National Renewable Energy Laboratory (NREL) to provide the DOE energy efficiency and renewable energy R\&D programs with an economic analysis tool to use in planning activities. Other models would be expected to produce the same results given the same inputs.

An energy planner calculates a COE that reflects the financial requirements of the system's prospective owner. For distributed energy systems, these financial requirements can take many forms because of the multitude of applications and owner types that might use a distributed technology. It is not practical for a document such as this to attempt to explore this wide range. Instead, this chapter provides a simplified overview of financial perspectives. Its purpose is to provide an indication of relative rankings of energy costs and cost trends for the DER technologies characterized. Furthermore, it only discusses combined heat and power (CHP) systems because they provide, in general, the most financially attractive applications and are expected to be predominant in the marketplace.

\subsection{Calculation of Levelized Cost of Energy}

The approach used is relatively simple. First, because CHP systems produce both electricity and heat, and these two outputs in effect compete with each other, it is desirable to have a single, composite measure of cost-effectiveness. To this end, we assume that the system is sized to match the thermal load of the installation. As such, the thermal output of the system provides heat that would have otherwise been generated by separate means, and displaces the fuel that would have been consumed in meeting that thermal requirement. ${ }^{1}$ The financial calculation used here, therefore, credits that fuel savings against the other project expenses. The model then calculates the value for the price of the electric output that yields a total after-tax internal rate of return of $15 \%$. An example of one particular analysis, for $70-\mathrm{kW}$ microturbines, is presented in Table $\mathbf{1}$.

Table 1. Example Calculation of Levelized COE (for $70 \mathrm{~kW}$ Microturbines)

\begin{tabular}{|l|l|}
\hline System Size & $70 \mathrm{~kW}$ \\
\hline Capital Cost & $\$ 1,620 / \mathrm{kW}$ \\
\hline CHP heat rate & $7,325 \mathrm{Btu} / \mathrm{kWh}$ \\
\hline Fuel Use & $2.27 \mathrm{MMBtu} / \mathrm{hr}$ \\
\hline Annual Electrical Output & $582,000 \mathrm{kWh} / \mathrm{yr}$ \\
\hline Natural Gas Price & $\$ 3.76 / \mathrm{MMBtu}$ \\
\hline Annual Thermal Output (Thermal Credit) & $0.74 \mathrm{MMBtu} / \mathrm{hr}$ \\
\hline Levelized Cost of Energy (constant 2003 \$) & $\$ 0.097 / \mathrm{kWh}$ \\
\hline
\end{tabular}

\footnotetext{
${ }^{1}$ It is assumed that the displaced heat would have been generated at $80 \%$ efficiency.

Gas-Fired Distributed Energy Resource Technology Characterizations

Financial Evaluations - Page 7-1
} 
The calculation is performed for a 20-year time horizon, which is interpreted as the project lifetime. Project operation and maintenance costs, as provided in the TC chapters, have been carefully reviewed to ensure that they are adequate to cover not only routine maintenance, but to also include overhauls at industry-standard times. For example, if a reciprocating engine technology requires a major overhaul after 80,000 hours of operation, the value for O\&M for that technology includes that overhaul expense. As described in the TC chapters, O\&M estimates are frequently derived from O\&M contract prices that are guaranteed by the equipment manufacturers.

Once the stream of costs and revenues that yields the required internal rate of return (the sum of the net present values of the annual values is zero) is determined, an equivalent constant dollar levelized stream of revenues is calculated assuming a discount rate of $10 \%$. The value of $10 \%$ is used because it represents a risk-free discount rate, the use of which is generally accepted as appropriate for levelization calculations. COE results are expressed in levelized constant 2003 dollars, as the cost data in each TC is also stated in 2003 dollars. General inflation is estimated at $2.5 \%$ per year. Tax calculations reflect an assumed $40 \%$ combined corporate rate (i.e., federal at $35 \%$ and state at $7.7 \%$, with state deductible from federal). Depreciation was calculated using the simplified approach of straight-line over 20 years. No accelerated depreciation was assumed, although such may be available under current or future law.

To determine the electricity revenue stream that yields the required internal rate of return, the user specifies a real rate of escalation of electricity prices. The user next guesses a value for the first year's electricity. The assumed escalation rate is then applied to that first-year value to calculate a changing stream of electricity revenues. If there is no assumed escalation in real (without inflation) electricity prices during the 20-year period, the revenue stream would be level, or even declining if electricity prices are assumed to decrease over time. The value for the first-year COE, when coupled with an assumed escalation rate, also uniquely describes the project's cost of generating electricity. The first-year COE is often casually quoted as the project bid price. However, without also quoting any changes in that price over time (such as an escalation rate), reference to the firstyear price as being indicative of the project should be avoided.

\subsection{Gas Price Assumptions}

The analyses in this chapter use Energy Information Administration (EIA) projections for natural gas prices, as described in the Annual Energy Outlook 2003. The gas prices used are delivered natural gas prices for industrial users, as outlined in Table A.14 of that document. Table 2 provides an overview of those prices for the years in this analysis.

Table 2. Delivered Industrial Gas Prices Used in Cost of Energy Estimates

\begin{tabular}{|l|l|l|l|l|l|}
\hline Delivered Industrial Prices (\$/MMBtu) \\
\hline
\end{tabular}


Notice in the table that prices are projected to fall back in 2005 from current levels, only to increase during the remaining period. Because changing gas prices can mask underlying technology changes, this chapter also provides a set of COE calculations for a constant natural gas price (the 2003 value of \$3.97/MMBtu).

\subsection{Overview of Results}

Table 3 provides an overview of COE results for CHP applications for selected sizes of each of the distributed technologies in this report.

Table 3. Cost of Energy Trends for Selected Distributed Gas Technologies in CHP Applications

\begin{tabular}{|l|c|c|c|c|c|c|}
\hline Levelized Cost of Energy (cents/kWh) & $\begin{array}{c}\mathbf{2 0 0 3} \\
\text { (Current } \\
\text { Status) }\end{array}$ & $\mathbf{2 0 0 5}$ & $\mathbf{2 0 1 0}$ & $\mathbf{2 0 2 0}$ & $\mathbf{2 0 3 0}$ \\
\hline $\begin{array}{l}\text { Reciprocating } \\
\text { Engines }\end{array}$ & $1 \mathrm{MW}$ & 5.4 & 5.1 & 5.0 & 5.1 & 5.2 \\
\hline Gas Turbines & $10 \mathrm{MW}$ & 5.3 & 4.9 & 5.0 & 5.0 & 4.9 \\
\hline Microturbines & $200 \mathrm{~kW}$ & $\mathrm{nc}$ & 8.0 & 7.4 & 5.6 & 5.4 \\
\hline Fuel Cells (PEMFC) & $200 \mathrm{~kW}$ & $\mathrm{nc}$ & 13.3 & 10.1 & 7.6 & 6.3 \\
\hline $\begin{array}{l}\text { Small Steam } \\
\text { Turbines }\end{array}$ & $3 \mathrm{MW}$ & 3.2 & $\mathrm{nc}$ & 3.2 & 3.5 & 3.8 \\
\hline nc - not characterized & & & & & & \\
\hline
\end{tabular}

As can be seen from the table, the reduction in $\mathrm{COE}$ is projected to be much greater for microturbines and fuel cells than for the other three technologies. This result is as expected, given the relative immaturity of those two technologies. (When examining the results in Table 3, the reader should keep in mind that the results are meant to provide insights into relative trends, and should not be taken as absolute in any sense.)

Table 4 expands on the summary results in Table 3 by providing COE values for all sizes of each technology. As with Table 3, these results should be used primarily to identify size- and timedependent trends.

\subsection{Calculation of COE with Constant Gas Prices}

Table 5 provides results of COE calculations assuming that gas prices remain at 2003 levels. Although unrealistic and of no use for estimating future technology competitiveness in the marketplace, this calculation does provide an important insight into how technology cost and performance improvements, over time, will improve the technology. The cost-reduction trends for microturbines and fuel cells are marked, and would be expected. Conversely, small steam turbines are generally seen to be a quite mature technology. 
Table 4. Cost of Energy Trends for Distributed Technologies

\begin{tabular}{|c|c|c|c|c|c|c|}
\hline \multicolumn{7}{|c|}{ Levelized Cost of Energy (cents/kWh) } \\
\hline & & $\begin{array}{c}2003 \\
\text { (Current } \\
\text { Status) }\end{array}$ & 2005 & 2010 & 2020 & 2030 \\
\hline \multirow{5}{*}{$\begin{array}{l}\text { Reciprocating } \\
\text { Engines }\end{array}$} & $100 \mathrm{~kW}$ & 6.8 & 6.3 & 5.8 & 5.6 & 5.6 \\
\hline & $300 \mathrm{~kW}$ & 5.9 & 5.7 & 5.7 & 5.4 & 5.5 \\
\hline & $1 \mathrm{MW}$ & 5.4 & 5.1 & 5.0 & 5.1 & 5.2 \\
\hline & $3 \mathrm{MW}$ & 5.4 & 5.1 & 5.0 & 5.1 & 5.2 \\
\hline & $5 \mathrm{MW}$ & 5.0 & 4.8 & 4.8 & 4.8 & 5.0 \\
\hline \multirow[t]{4}{*}{ Gas Turbines } & $5 \mathrm{MW}$ & 5.6 & 5.3 & 5.1 & 5.1 & 5.2 \\
\hline & $10 \mathrm{MW}$ & 5.3 & 4.9 & 5.0 & 5.0 & 4.9 \\
\hline & $25 \mathrm{MW}$ & 4.6 & 4.4 & 4.5 & 4.4 & 4.6 \\
\hline & $40 \mathrm{MW}$ & 4.2 & 4.1 & 4.2 & 4.3 & 4.5 \\
\hline \multirow[t]{5}{*}{ Microturbines } & $30 \mathrm{~kW}$ & 9.8 & 9.4 & 8.6 & 7.5 & 7.1 \\
\hline & $70 \mathrm{~kW}$ & 8.9 & 8.3 & 7.6 & 6.7 & 6.4 \\
\hline & $100 \mathrm{~kW}$ & 8.6 & 7.9 & 6.9 & 6.1 & 6.0 \\
\hline & $200 \mathrm{~kW}$ & nc & 8.0 & 7.4 & 5.6 & 5.4 \\
\hline & $500 \mathrm{~kW}$ & nc & $\mathrm{nc}$ & 6.7 & 5.7 & 5.5 \\
\hline Fuel Cells (PEMFC) & $10 \mathrm{~kW}$ & nc & 18.6 & 13.8 & 9.6 & 7.7 \\
\hline Fuel Cells (PEMFC) & $200 \mathrm{~kW}$ & nc & 13.3 & 10.1 & 7.6 & 6.3 \\
\hline Fuel Cells (MCFC) & $250 \mathrm{~kW}$ & 18.4 & 17.3 & 11.5 & 9.3 & 7.4 \\
\hline Fuel Cells (MCFC) & $2 \mathrm{MW}$ & $\mathrm{nc}$ & 13.0 & 9.7 & 7.5 & 6.4 \\
\hline Fuel Cells (SOFC) & $100 \mathrm{~kW}$ & $\mathrm{nc}$ & 13.0 & 9.6 & 8.1 & 6.3 \\
\hline \multirow{3}{*}{$\begin{array}{l}\text { Small Steam } \\
\text { Turbines }\end{array}$} & $500 \mathrm{~kW}$ & 4.4 & $\mathrm{nc}$ & 4.4 & 4.6 & 4.7 \\
\hline & $3 \mathrm{MW}$ & 3.2 & $\mathrm{nc}$ & 3.2 & 3.5 & 3.8 \\
\hline & $15 \mathrm{MW}$ & 3.0 & $\mathrm{nc}$ & 3.1 & 3.3 & 3.5 \\
\hline
\end{tabular}

Table 5. Cost of Energy Trends for Selected Distributed Technologies, Assuming Constant Gas Prices

\begin{tabular}{|c|c|c|c|c|c|c|}
\hline \multicolumn{7}{|c|}{ Levelized Cost of Energy (cents/kWh) } \\
\hline & & $\begin{array}{c}2003 \\
\text { (Current } \\
\text { Status) } \\
\end{array}$ & 2005 & 2010 & 2020 & 2030 \\
\hline Gas Turbines & $10 \mathrm{MW}$ & & & & & \\
\hline Steam Turbines & $3 \mathrm{MW}$ & 3.1 & nc & 3.1 & 3.1 & 3.1 \\
\hline Microturbines & $200 \mathrm{~kW}$ & $\mathrm{nc}$ & 8.0 & 7.2 & 5.2 & 4.7 \\
\hline $\begin{array}{l}\text { Reciprocating } \\
\text { Engines }\end{array}$ & $1 \mathrm{MW}$ & 5.3 & 5.2 & 4.9 & 4.8 & 4.6 \\
\hline Fuel Cells (PEMFC) & $200 \mathrm{~kW}$ & nc & 13.5 & 10.0 & 7.2 & 5.7 \\
\hline
\end{tabular}


Table 6 provides details of the constant fuel price COE for all sizes of gas turbines. Technology improvements are clearly seen in this table, and reductions in COE can be traced directly back to cost and performance improvements described in the Gas Turbine technology characterization. The trends for gas turbines are presented to illustrate, for a single technology, how the technology characterization data can be used for R\&D planning purposes and for tracking the progress of R\&D programs. Other technologies would show other trends.

Table 6. Cost of Energy Trends for Gas Turbines, Assuming Constant Gas Prices

\begin{tabular}{|l|c|c|c|c|c|c|}
\hline Levelized Cost of Energy (cents/kWh) & $\mathbf{2 0 0 3}$ & $\mathbf{2 0 0 5}$ & $\mathbf{2 0 1 0}$ & $\mathbf{2 0 2 0}$ & $\mathbf{2 0 3 0}$ \\
\hline \multirow{7}{*}{ Gas Turbines } & $\begin{array}{c}\mathbf{2 0 0 3} \\
\text { Status) }\end{array}$ & 5.6 & 5.3 & 4.9 & 4.6 & 4.5 \\
\cline { 2 - 7 } & $5 \mathrm{MW}$ & 5.2 & 5.0 & 4.8 & 4.5 & 4.3 \\
\cline { 2 - 7 } & $10 \mathrm{MW}$ & 4.5 & 4.5 & 4.3 & 4.0 & 4.0 \\
\cline { 2 - 7 } & $25 \mathrm{MW}$ & 4.1 & 4.1 & 4.0 & 3.9 & 3.8 \\
\hline
\end{tabular}




\section{Appendix - Stirling Engine Systems}

\subsection{Overview}

The Stirling engine was first patented in 1816 by Robert Stirling as a water pump for mining operations. It was an alternative to steam-driven pumps, which had the unfortunate tendency to occasionally blow up. It was a decade later when the thermodynamic principles behind the device were worked out. Since that time, Stirling engines have continued to capture the imagination of entrepreneurs, engineers, and investors. They are attracted by its potential for high efficiency, quiet operation, low emissions, and fuel flexibility.

Stirling engines have been incorporated into solar-dish concentrators, cryogenic coolers, residential heat and power systems, submarine propulsion systems, and distributed generation systems concepts. Today, a search of the Internet produces more than 25 companies promoting the Stirling engine; but there has been little, if any, commercial success to date in power generation or combined heat and power (CHP) applications

Stirling engines are heat engines that operate on the Carnot cycle - the Carnot cycle can be thought of as the most efficient heat engine cycle allowed by physical laws. However, the practical translation of this theory into hardware has resulted in only modest electrical generation efficiencies - equivalent to microturbines - and slightly less than reciprocating engines. Hot water can be produced from the engine cooling and lubrication system and the exhaust gas - and can result in overall thermal efficiencies approaching $80 \%$. This would make these systems attractive in residential or small industrial and commercial applications. The models currently under development are in the 1 to $55 \mathrm{~kW}$ range. The lower end of the range is best suited for residential applications, while the higher fits a small commercial application. The packages can be installed in multiples to obtain larger outputs.

The engine package uses a separate combustion chamber, which facilitates engineering a lowemissions combustor. It also allows the potential use of a wide range of fuels, including natural gas, propane, oil, biomass, waste fuels, etc. Stirling engines also can use any source of hightemperature heat: The engines have been combined with solar-dish concentrators in 1 to $5 \mathrm{~kW}$ systems. Surplus heat from industrial processes can be used, but it must be at least $1600^{\circ} \mathrm{F}$ for the engine to function, and noncorrosive. Existing prototypes have achieved single-digit $\mathrm{NO}_{\mathrm{x}}$ levels.

While Stirling engines are worthy candidates for distributed generation and combined heat and power applications, they face formidable hurdles to establishing a beachhead in the marketplace. The incumbents - such as reciprocating engines or gas turbines - have been the beneficiaries of literally billions of dollars and decades of development. An application where the intrinsic characteristics of Stirling engine produce a benefit/cost ratio unmatched by the competition has yet to be discovered. Most of the companies promoting Stirling engines for distributed generation have not progressed to a standard product line. Field demonstrations are few and far between - and field-test results are not being offered to the public. 
The most active company developing Stirling engine distributed generation technology is STM Power, Inc., of Ann Arbor, Michigan. STM and its principals have been engaged in Stirling engine technology and distributed power technology for several decades. They are on an aggressive development and commercialization track, supported by substantial investor funding. STM is ahead of anyone else in the world in the development of a commercial product line. They plan to introduce a $55 \mathrm{~kW}$ unit in Fall 2003. This unit will draw on the experience gained in developing a $25 \mathrm{~kW}$ unit, the STM 4-120. Ten units are being tested, and STM's lab and STM is planning to put nearly 40 units into field tests. The testing of subsystems for the 4-260, a 55 kW model, was underway as of Summer 2003.

The performance information presented here is based on information provided by $\boldsymbol{S T M}$ for its new $55 \mathrm{~kW}$ unit. STM has developed a detailed, proprietary, five-year business plan for the introduction of these units - and has provided projected performance data for this technology characterization.

\subsection{Applications}

As of the date of this document, Stirling engines are not in any bona fide commercial market. Therefore, this section will discuss the potential applications for Stirling engines.

\subsection{Power-Only}

Stirling engines are prime movers, and therefore can be used to supply shaft power for pumps, electric generators, or other mechanical drive applications. The technology is being developed to serve the following power-only applications:

- Stationary Power Generation, Distributed Generation

$\circ$ Peak shaving and base-load power

- Stand-alone power

○ Backup/standby power

- Microgrid

○ Resource recovery (e.g., landfill gas)

Another major avenue of development is an application for solar-energy dish concentrators; however, this application will not be discussed in any detail, because it is not natural gas-fired, the focus of this technology characterization.

STM has identified landfill gas and wastewater treatment facilities as initial targets for the introduction of its new $55 \mathrm{~kW}$ unit. These markets also are the target for microturbines, and are currently served primarily by reciprocating engines.

The Stirling engine's ability to use any source of heat also makes them candidates for use as heat-recovery devices in industrial processes. The source of heat, (e.g., from a furnace or kiln flue), must be between 1600 and $1800^{\circ} \mathrm{F}$, noncorrosive, and have a heat content of at least $315,000 \mathrm{Btu} / \mathrm{hr}$ for a $25 \mathrm{~kW}$ unit. Future models may be able to handle heat sources between 
1800 and $2000^{\circ} \mathrm{F}$ and achieve electric conversion efficiencies approaching 50\%. STM has conducted field tests of this application with their $25 \mathrm{~kW}$ model. Commercial follow-on applications have not been secured as of this date.

\subsection{Combined Heat and Power}

In a typical Stirling engine, about $30 \%$ of the heat input is converted to electric power, and $70 \%$ of the heat input is rejected to the cooling system and exhaust gases, so there is a good potential for water heating or other low-temperature heating. Because Stirling engines are liquid-cooled, it is relatively easy to capture heat for CHP applications through a simple liquid-to-liquid heat exchanger. The only difference between a "power only" package and a CHP package is the addition of the heat exchanger and related control elements. The STM $55 \mathrm{~kW}$ PowerUnit engine will have a thermal output of $313,400 \mathrm{Btu} / \mathrm{hr}\left(92 \mathrm{~kW}_{\text {th }}\right)$ at $140^{\circ} \mathrm{F}(\max )$ and $8 \mathrm{gpm}$. With these characteristics, Stirling engines would achieve CHP thermal efficiencies approaching $80 \%$ at competative reasonable costs with a suitable thermal host. Potential applications would include small commercial building heating/cooling systems, hotels or laundries.

\subsection{Technology Description}

\subsection{Basic Process and Components}

A Stirling engine works by alternatively heating and cooling a working gas. Heat is provided at a constant temperature at one end of a cylinder (the hot end), while heat is rejected at constant temperature at the opposite end (the cold end). Work is created as the expanding gas pushes against a piston. The working gas is transferred back and forth between the two chambers, often with the aid of a "displacer piston." The working gas is generally compressed in the cold chamber and generally expanded in the hot chamber to produce power. A regenerator is used between the hot and cold chambers of the machine to increase the energy-conversion efficiency.

Figure 1. Stirling Engine Fundamentals
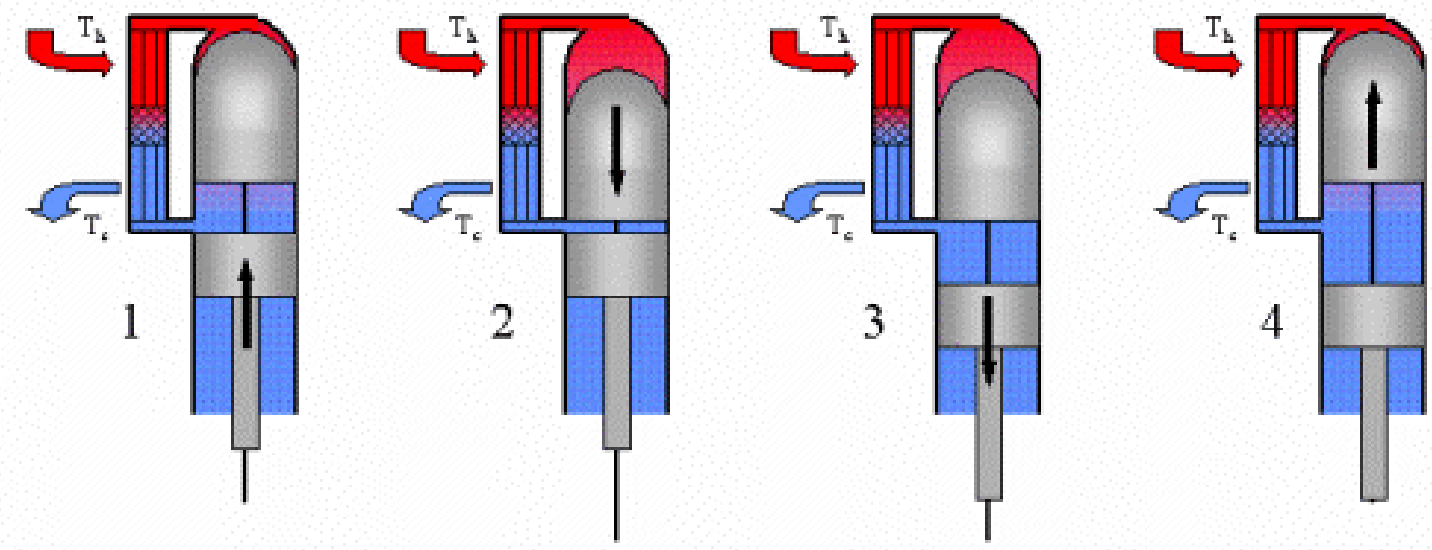

Source: NASA 
The basic working of the Stirling engine is shown in Figure 1:

1. The piston rises; the working gas is compressed.

2. The gas is displaced from the cold chamber to the hot chamber, passing through the regenerator; the pressure increases further.

3. The piston falls; the gas is expanded.

4. The gas is displaced from the hot chamber to the cold chamber; the pressure decreases further.

\section{Thermodynamic Cycle}

The Carnot Cycle describes the most efficient heat-engine cycle allowed by the Second Law of Thermodynamics. Starting from Point 1 in Figure 2 below, the working gas is compressed, resulting in an increase in pressure of the working gas throughout the engine.

Figure 2. Carnot Cycle Compared to the Stirling Engine
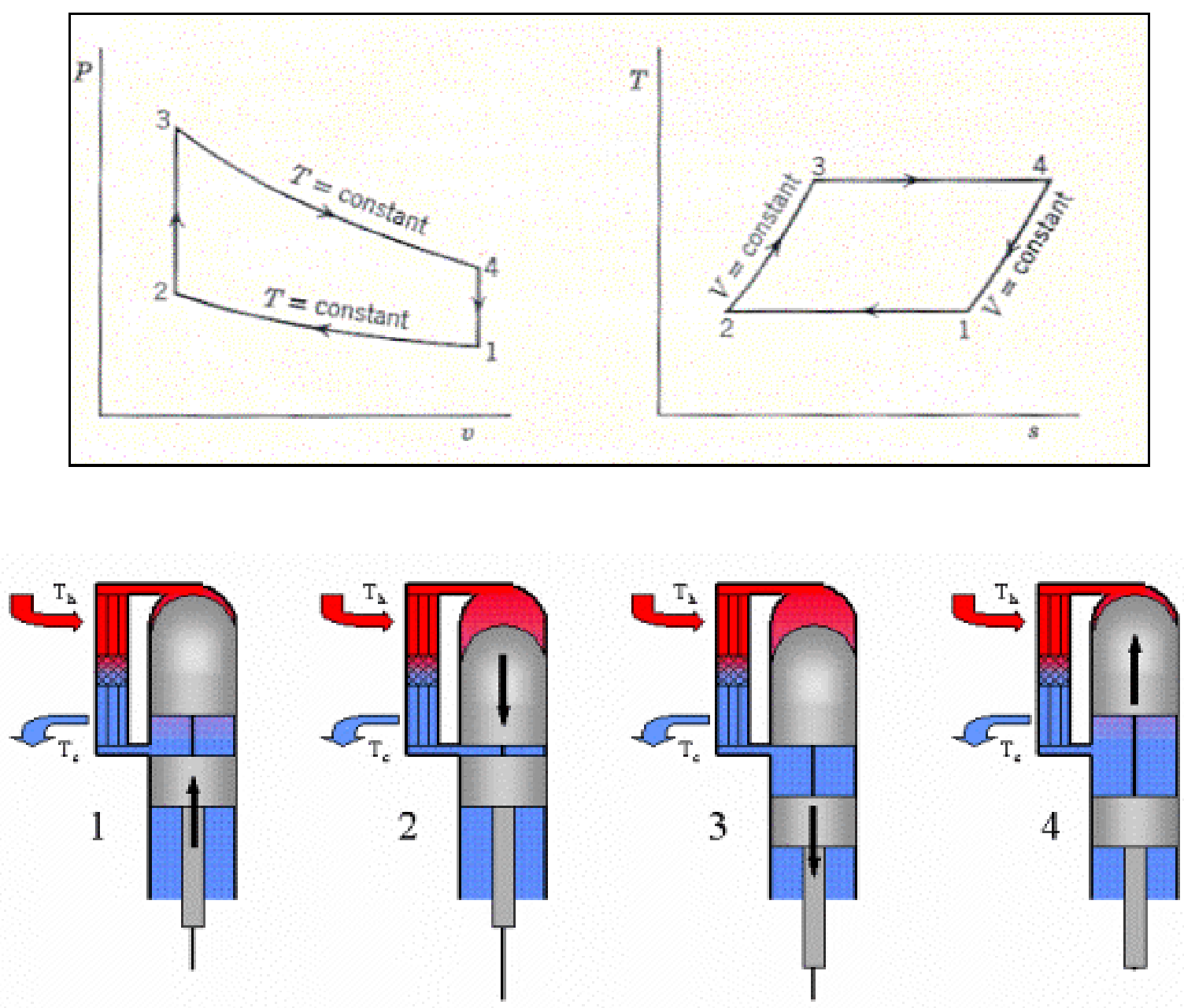

Heat generated from this process is dissipated to the cold sink $\left(T_{c}\right)$ in an isothermal process. Moving from 2 to 3, the gas picks up heat stored in the regenerator, and the pressure of enclosed gas increases further, without a change in volume. From 3 to 4 , gas expands isothermally. 
External heat is provided during this process to keep the temperature constant. From 4 to 1 , the working gas is expanded further in a constant volume process as the gas goes through the regenerator to its original position while rejecting heat to the regenerator.

The maximum Carnot efficiency, according to the Second Law of Thermodynamics, is:

$$
\text { efficiency }_{\max }=1-\left(\mathrm{T}_{\text {cold }} / \mathrm{T}_{\text {hot }}\right)
$$

For a hot source at $1600^{\circ} \mathrm{F}$ and a cold sink at $70^{\circ} \mathrm{F}$, the Carnot efficiency is $74 \%$. Most Stirling engine prototypes are operating at an electric-conversion efficiency in the high $20 \%$ range. The difference is due to the practical inefficiencies of friction loss, heat-transfer ineffectiveness at the hot and cold ends and in the regenerator, and losses through engine seals.

The basic components of a Stirling engine package for distributed generation applications would include the Stirling engine core, combustion package, lubricating oil system, engine-cooling system, and control system (See Figure 3).

\section{Figure 3. STM 4-120 PowerUnit Packaged DG System}

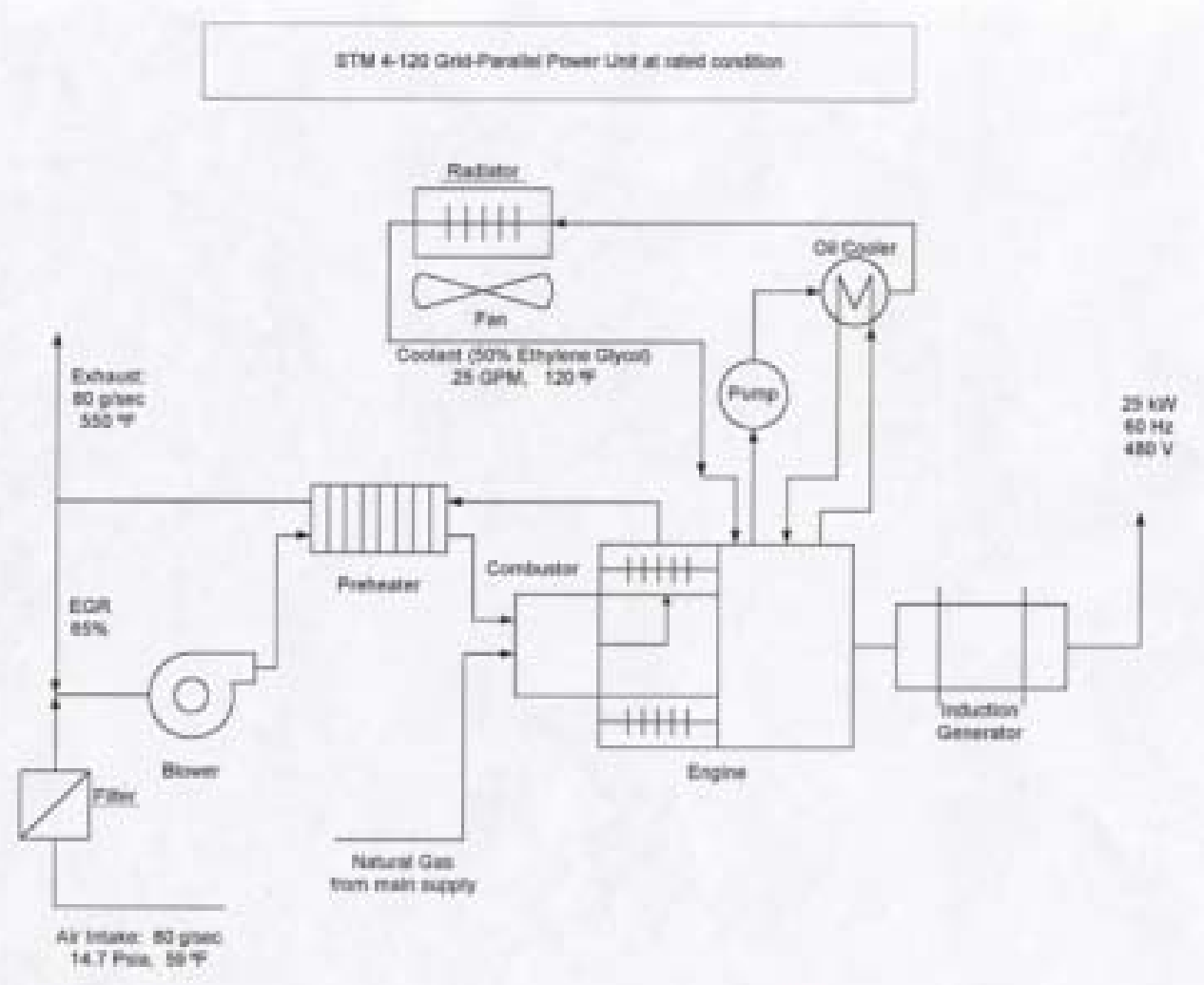

Source: STM Power, Inc.

Depending on whether the Stirling engine system is grid-parallel or grid-independent, an induction generator or a synchronous generator is used to produce electricity. In fact, most 
Stirling engine systems are designed to run at either 1,500 rpm (for $50 \mathrm{~Hz}$ ) or 1,800 rpm (for 60 $\mathrm{Hz}$ ), which is a cost advantage for these Stirling engine models. Induction generators are offthe-shelf items and convert mechanical power to electricity with an efficiency of about $94 \%$. Parasitic power required for operation of the cooling system fan and pump, oil pump, and control system is typically about $1 \mathrm{~kW}_{\mathrm{e}}$.

One of the attractive features of Stirling engines is their ability to utilize heat from a variety of sources. In practice, the systems are designed with a specialized combustor to accommodate a particular fuel. The combustor is independent of the "power" section of the engine, allowing designers the flexibility to achieve low emissions and optimum heat transfer to the hot-end head of the engine core. This "external" combustor is akin to combustion turbines and microturbines, and provides an advantage - especially with regard to emissions - over reciprocating engines. While a single combustion chamber will work for most of the common fuels (i.e., natural gas, propane, No. 2 oil, landfill gas), changes in the fuel nozzles, and possibly the combustion air system, will be required for each fuel. Changes to the combustion itself will be required for solid fuels or "exotic" waste fuels. Several developers have special biomass models in various stages of development.

\subsection{Types of Stirling Engines}

The two major types of Stirling engine are known as the "kinematic" and "free piston." In the former, the piston(s) are connected by means of connecting rods and crankshaft, or with a swash plate (also known as a wobble plate). A swash plate is commonly used to control the pitch of helicopter rotor blades. In the STM Stirling engine, the swash plate controls the stroke, and thus the output. The swash plate allows for variable output while maintaining the thermal input, allowing faster response to changes in demand.

Figure 4. STM 4-120 Kinematic Stirling Engine Core

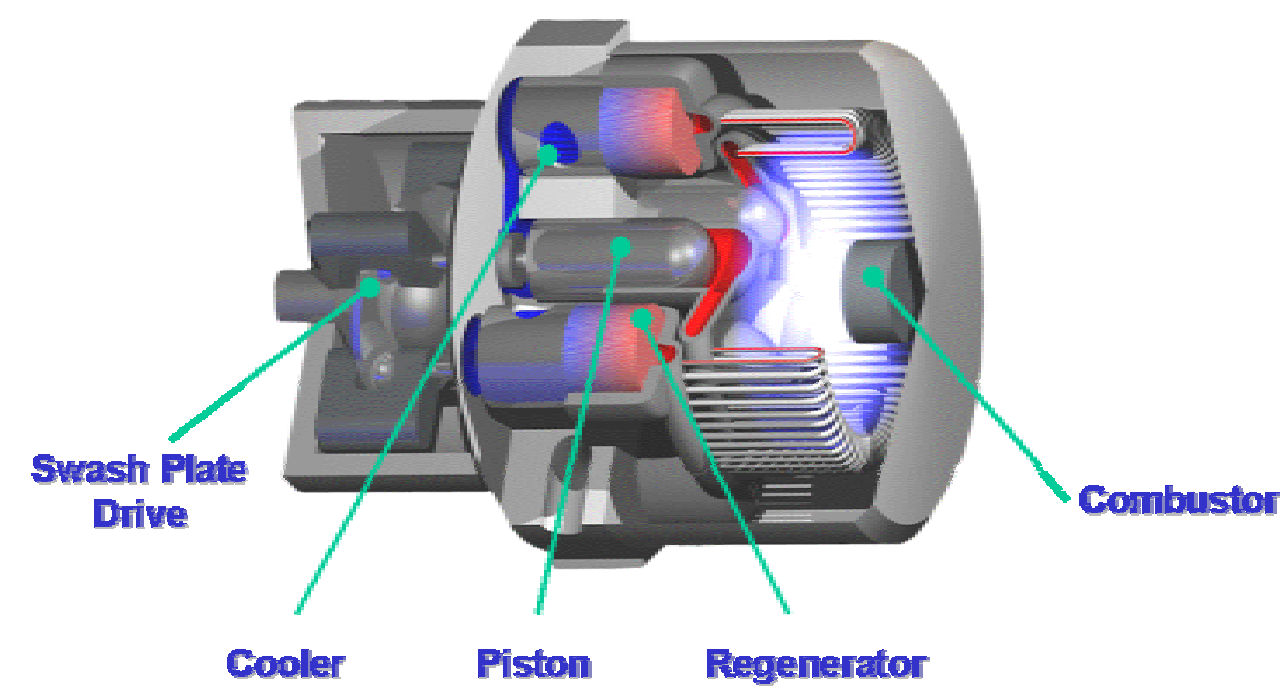

Source: STM Power, Inc. 
Kinematic Stirling engines can be designed as either single- or double-acting engines. Singleacting kinematic Stirling engines can have one or more cylinders, with varying designs for mechanical linkage. Double-acting kinematic Stirling engines require several cylinders. The working gas in a double-acting configuration operates on opposite faces of the piston. The Stirling Thermal Motors (STM) design for its 4-120 engine (see Figure 4) involves four parallel cylinders, where the reciprocating piston motions are linked to a swash plate via one rotating shaft.

Free-piston Stirling engines do not have any mechanical linkage between the piston and the power output. The pistons are mounted in flexures and oscillate freely. Flexures are springs that are flexible in the axial direction, but very stiff in the radial direction. A fluid or a linear alternator receives the reciprocating output via pneumatic transfer. The free-piston engine is a single-acting engine. Since the working gas in the single-acting design only operates on one face of a piston, two pistons are required in each cylinder - one for displacement and one for power. Free-piston configurations have to-date been limited to small sizes (below $12.5 \mathrm{~kW}$ ).

An important element of a Stirling engine is the working fluid. In theory, any fluid could be used, but given the heat transfer characteristics of the candidates, hydrogen or helium are typically preferred. However, the use of hydrogen introduces several design issues, e.g., engine seals, corrosion and embrittlement, and working fluid makeup. To address the loss of hydrogen in its designs, STM has incorporated an on-board hydrogen generator.

\subsection{Design Characteristics}

The following characteristics define the features of modern Stirling engine systems, which could potentially result in this technology evolving into a MAJOR prime mover for distributed generation and CHP:

Size range:

Companies in the industry are reporting systems under development that range from 55 watts to 3,000 watts. The two most common ranges are 1 to $5 \mathrm{~kW}_{\mathrm{e}}$ and STM's $55 \mathrm{~kW}_{\mathrm{e}}$. The systems are suitable for modular installation, and several companies will offer control software for controlling multiple units. STM plans to develop a 200 $\mathrm{kW}$ unit in the future.

Thermal output: $\quad$ Due to temperature limitations of the engine components, heat recovery from coolant systems account for almost $50 \%$ of the heat input. This results in a significant amount of heat suitable for space heating, cooking, potable hot water, and low temperature processes $\left(<140^{\circ} \mathrm{F}\right)$. STM's $55 \mathrm{~kW}_{\mathrm{e}}$ engine will produce $92 \mathrm{~kW}_{\text {th }}$, while a $3 \mathrm{~kW}_{\mathrm{e}}$ engine will produce $6 \mathrm{~kW}$ th.

Fuel flexibility: $\quad$ Stirling engines generally require a heat source between $1500^{\circ} \mathrm{F}$ and $1800^{\circ} \mathrm{F}$. This heat source can be derived from any noncorrosive fuel that is relatively free of particulates. Rejected heat from other processes that meet these requirements also can be used. Gaseous 
Reliability and life:

Emissions:

Modularity:

Part-load operation:

Dimensions:

Quiet operation:

Operating environment: The engine core is sealed, so operation in a dirty environment will not be a problem for the engine; there could be issues with the combustion system and coolant system radiators.

\subsection{Cost and Performance Characteristics}

Most of the companies promoting Stirling engines for distributed generation have not progressed to a standard product line. Therefore, information on system design and performance is speculative at this time. However, STM Corporation is closer than most in offering a product. STM has been developing a $25 \mathrm{~kW}$ package, designated the STM 4-120. The company plans to introduce a $55 \mathrm{~kW}$ model, designated $4-260$, as its first commercial model. STM Power provided the performance data in Table 1. 
Table 1. Stirling Engine System - Expected Performance Parameters (2003)

\begin{tabular}{|c|c|}
\hline Cost and Performance Characteristics ${ }^{1}$ & STM Power Model 4-120 \\
\hline Nominal Capacity (kW) & 55 \\
\hline \multicolumn{2}{|l|}{ Engine Characteristics } \\
\hline Electrical Efficiency (\%), LHV & 30.6 \\
\hline Electric Heat Rate (Btu/kWh), $\mathrm{HHV}^{2}$ & 11,150 \\
\hline Electrical Efficiency (\%), $\mathrm{HHV}^{3}$ & 28.0 \\
\hline Fuel Input (Btu/hr) & 681,400 \\
\hline Package Cost $(2003 \$ / \mathrm{kW})^{4}$ & 1,000 \\
\hline Installed Cost - CHP $(2003 \$ / k W)^{5}$ & 1,615 \\
\hline Working gas & Hydrogen \\
\hline O\&M Costs, $(2003 \$ / k W h)$ & 0.008 \\
\hline Required Fuel Gas Pressure (psig) ${ }^{6}$ & 2.0 \\
\hline \multicolumn{2}{|l|}{ CHP Characteristics } \\
\hline Exhaust Temp $\left({ }^{\circ} \mathrm{F}\right)$ & 500 \\
\hline Coolant Heat Output (Btu/hr) ${ }^{7}$ & 313,400 \\
\hline Heat Output (kW equivalent) & 92 \\
\hline Total CHP Efficiency (\%), LHV & 81.7 \\
\hline Total CHP Efficiency (\%), $\mathrm{HHV}^{8}$ & 73.6 \\
\hline Heat/Fuel Ratio ${ }^{9}$ & 0.46 \\
\hline Power/Heat Ratio ${ }^{10}$ & 1.67 \\
\hline Net Heat Rate $(\mathrm{Btu} / \mathrm{kWh})^{11}$ & 5,453 \\
\hline
\end{tabular}

\section{Source: STM Power, Antares Group}

\footnotetext{
${ }^{1}$ Characteristics presented are STM Power's $55 \mathrm{kWe}$ commercial units, expected to be available in 2003.

${ }^{2}$ All turbine and engine manufacturers quote heat rates in terms of the lower heating value (LHV) of the fuel. On the other hand, the usable energy content of fuels is typically measured on a higher heating value (HHV) basis. In addition, electric utilities measure power plant heat rates in terms of HHV. For natural gas, the average heat content of natural gas is 1,030 Btu/scf on an HHV basis and $930 \mathrm{Btu} / \mathrm{scf}$ on an LHV basis - or about a $10 \%$ difference.

${ }^{3}$ Net electrical efficiency is gross efficiency - parasitic losses, which are already included. Base unit does not include radiator.

${ }^{4}$ Selling price for engine package, not including water-to-water heat exchanger for CHP application.

${ }^{5}$ Specification not provided by STM Power. . See cost components in Table 2.

${ }^{6}$ An optional fuel gas booster permits operation down to 0.25 psig (5.5 inches water) supply pressure.

${ }^{7}$ From coolant water only. STM does not envision recovering heat from the engine exhaust due to cost.

${ }^{8}$ Total CHP Efficiency $=($ net electric generated + net heat produced for thermal needs $) /$ total system fuel input.

${ }^{9}$ Heat/Fuel Ratio $=$ Thermal output (total heat recovered MMBtu/hr) as a fraction of fuel input (MMBtu/hr).

${ }^{10}$ Power/Heat Ratio $=($ CHP electric power output $($ Btu equivalent $)) /$ useful thermal output $($ Btu $)$.

${ }^{11}$ Net Heat Rate $=($ total fuel input to the CHP system - the fuel that would be normally used to generate the same amount of thermal output as the CHP system output assuming an efficiency of $80 \%$ )/CHP electric output (kW).
} 


\subsection{System Performance}

Although Stirling engines work on a simple principle, designers have historically faced challenges in striking a balance between efficiency, complexity, and cost. Stirling engine performance is generally sensitive to the following losses:

- Mechanical friction loss

- Piston rings, seals, and bearings

- Regeneration heat loss and other jacket losses

- Auxiliaries and accessories

- Combustion blower, oil pump, radiator fan, coolant pump, solenoids, actuators, and controls

- Mechanical/electric conversion loss

\subsection{Combined Heat and Power Performance}

One of the reasons that Stirling engines do not more closely approach Carnot efficiencies is the practical fact that engine components need to be cooled and lubricated. In a Stirling engine, 30\% of the heat input is converted to electric power, almost 50\% goes to the coolant, with the remaining power dissipated as exhaust or other losses. Power-only systems are typically equipped with a radiator and fan to dissipate the coolant heat into the air.

\subsection{Performance and Efficiency Enhancements}

\section{Electrical Efficiency}

The electrical efficiency of the STM Power 4-260 Stirling engine is $30.6 \%$ on a lower heating value basis (see note in Table 1). This is equivalent to an efficiency of $27 \%$ on a higher heating value basis. The equivalent heat rates are 11,150 Btu/kWh (LHV) and 12,390 Btu/kWh (HHV).

The efficiency is a function of the heater head temperature and the ambient temperature. As shown in Figure 5, the efficiency of the engine increases with higher hot end (or heater) temperature. The current constraint on moving toward higher temperatures is the cost of materials that can withstand these higher temperatures.

The ambient temperature - or the temperature to which the cold end rejects heat - also affects the engine efficiency. Higher ambient temperatures result in lower efficiencies and output. STM Power does not recommend operating the engine above $120^{\circ} \mathrm{F}$ ambient. 
Figure 5. Stirling Engine Efficiency

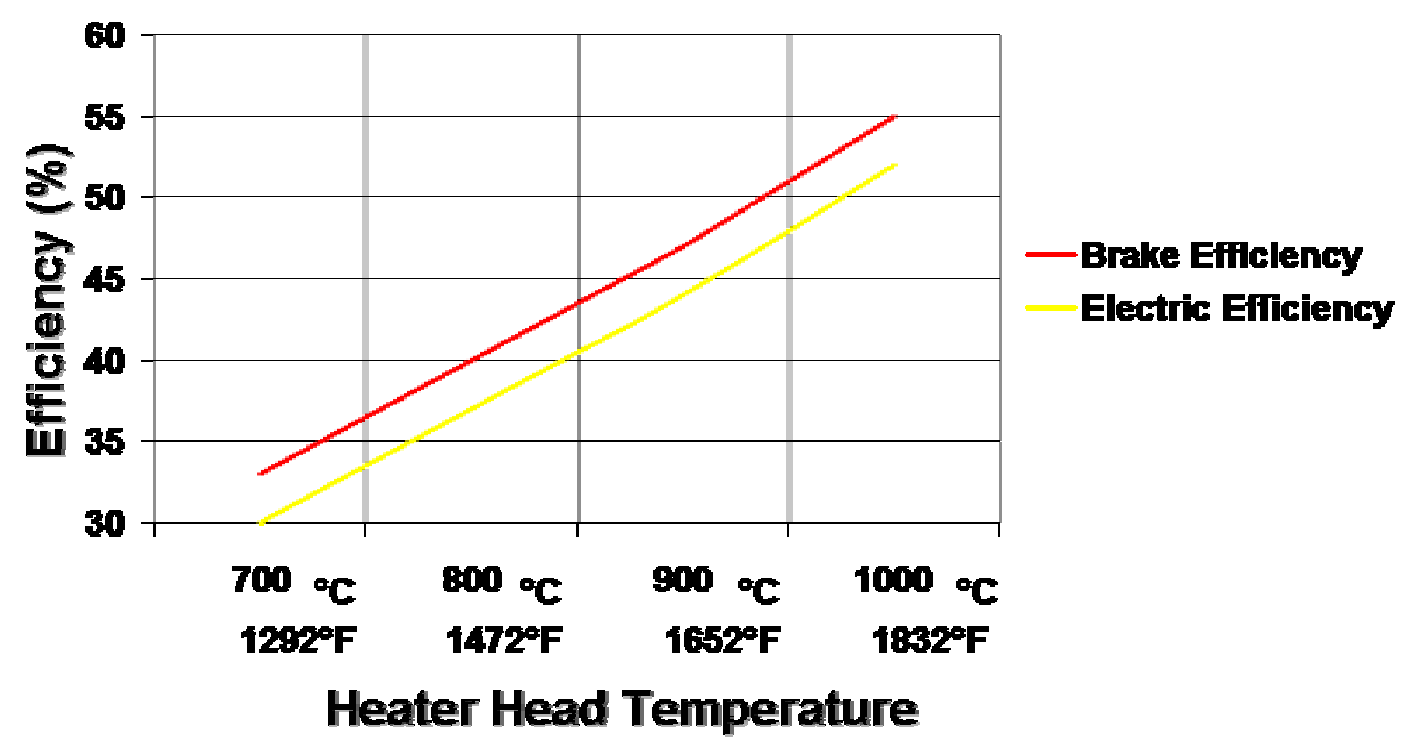

Source: STM Power, 2003

As with any air-breathing engine or combustion system, performance decreases with an increase in altitude due to density changes in the fuel and combustion air. STM has not released data yet, but the specifications recommend not operating at attitudes above 6,000 feet.

\section{Part-Load Performance}

The STM Power 4-260, is not currently designed for load-following.

Figure 6. Environmental Performance at Part-Load Conditions

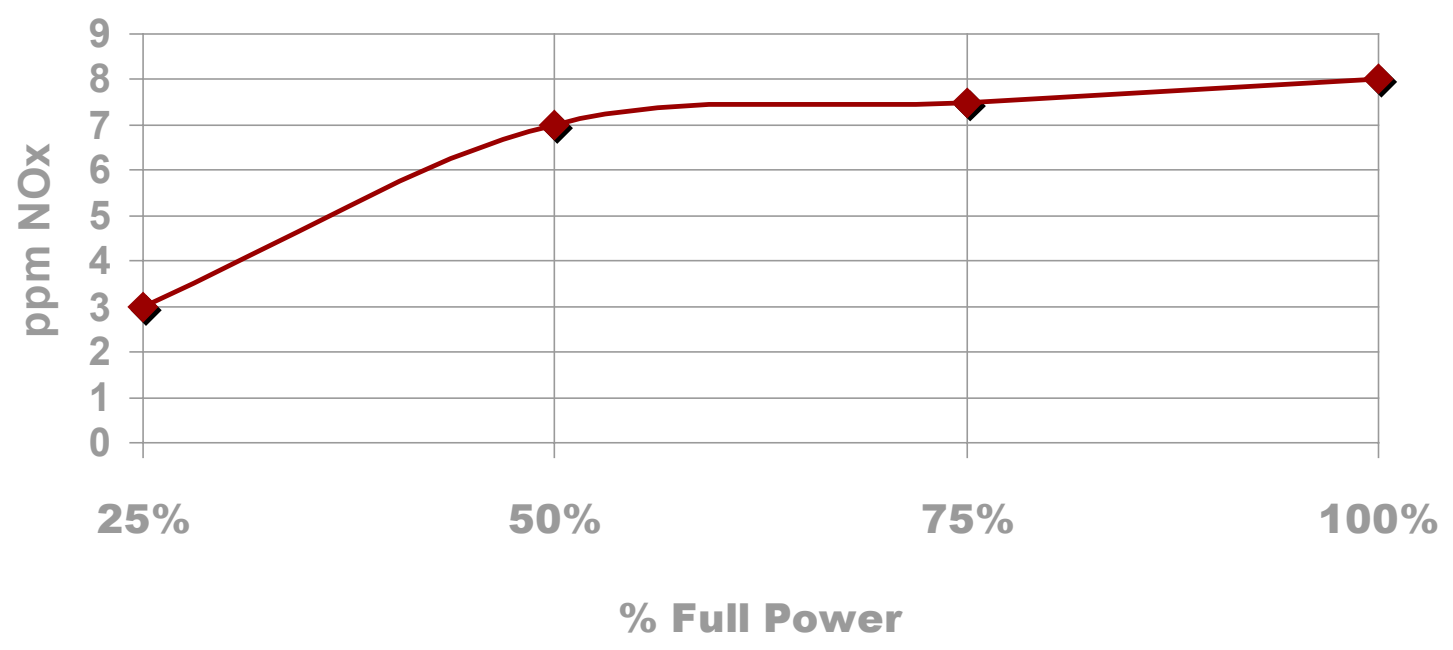

Source: STM Power, Inc., 2003 
A load-following model is under development at STM with the goal of obtaining operation at any point between nominal $(55 \mathrm{~kW})$ and zero output. This model will accomplish this by means of a swatch plate. The swash plate effectively varies the stroke of the pistons, and thus the output. This method simplifies the engine control system and allows much faster response to load changes, but will result in a slight loss of efficiency at part-loads. Data are not publicly available at this time.

The $\mathrm{NO}_{\mathrm{x}}$ emissions performance of the STM Power 4-120 $25 \mathrm{~kW}$ actually improves at part-load. (see Figure 6). This is primarily due to lower combustor temperatures at part load, which decreases thermal $\mathrm{NO}_{\mathrm{x}}$ formation. When firing natural gas, $\mathrm{SO}_{\mathrm{x}}$ will not be an issue. Comparable data for the $4-260,55 \mathrm{~kW}$ model are not yet available.

\subsection{Capital Cost}

This section provides an estimate for the installed cost of a Stirling engine system in a gridparallel configuration with CHP. These are "typical" budgetary price levels, and it should be noted that installed costs can vary significantly depending on the specifics of the plant equipment, geographical area, competitive market conditions, special site requirements, emissions-control requirements, prevailing labor rates, and whether the system is a new or retrofit installation. The cost figures in Table for the engine equipment have been provided by STM and represent their pricing strategy for entering the market. They do not necessarily represent the actual manufacturing and selling costs. Installation and non-equipment cost estimates by Antares and EEA. 
Table 2. Estimated Capital Cost for Stirling Engine in Grid-Parallel CHP Applications (2003) ${ }^{12}$

\begin{tabular}{|c|c|}
\hline Cost Component & STM 4-260 \\
\hline Nominal Capacity (kW) & 55 \\
\hline $\operatorname{Cost}(\$ / k W)$ & \\
\hline Stirling engine & 1,000 \\
\hline Gas booster compressor & $\mathrm{N} / \mathrm{A}$ \\
\hline Heat recovery & incl. \\
\hline Controls/Monitoring & Incl. \\
\hline Total Equipment & 1,000 \\
\hline Labor /Material & 150 \\
\hline Total Process Capital & 1,150 \\
\hline $\begin{array}{l}\text { Project and Construction } \\
\text { and Management }\end{array}$ & 282 \\
\hline Engineering and Fees & 123 \\
\hline Project Contingency & 60 \\
\hline Total Plant Cost $(\$ / k W)$ & $\$ 1,515$ \\
\hline
\end{tabular}

\subsection{Maintenance}

Maintenance costs and procedures have not yet been developed due to the lack of any long-term operating experience. However, Stirling engines are sealed devices and have fewer moving parts than reciprocating engines, plus a much slower operating speed.

The STM Power 4-260 engine is designed for a 40,000-hour life. The engine would be replaced at the end of this period. Periodic maintenance after 8,000 hours would include oil and oil filter changes, air filter replacement, etc.

An important maintenance item is the working gas makeup. The engine operates with a relatively high working pressure. Due to its small molecular size, hydrogen can escape through the engine seals and even through thin-walled tubing. Currently, hydrogen must be injected into the engine periodically. STM Power is developing a Proton Exchange Membrane (PEM) system that will

\footnotetext{
12 The cost figures for the engine equipment have been provided by STM and represent their pricing strategy for entering the market. They do not necessarily represent the actual manufacturing and selling costs. Installation and non-equipment cost estimates by Antares and EEA.
} 
convert water into hydrogen on a continuous basis. This approach is expected to consume about 2.5 gallon of water per year (8,000 hours).

\subsection{Fuels}

Stirling engines generally require a heat source between $1500^{\circ} \mathrm{F}$ and $1800^{\circ} \mathrm{F}$. This heat source can be derived from any noncorrosive fuel that is relatively free of particulates. Rejected heat from other processes that meet these requirements also can be used. Gaseous fuels must have a minimum of $300 \mathrm{Btu} / \mathrm{SCF}$ and $\mathrm{H}_{2} \mathrm{~S}$ content less than 7\%. The combustor requires a minimum of 2 psig supply pressure (otherwise a fuel gas booster is required with a minimum inlet pressure of 5.5 inches of water column).

Candidate fuels include:

- Liquid fuels (distillate oil)

- Liquefied petroleum gas (LPG) - propane and butane mixtures

- Sour gas - unprocessed natural gas as it comes directly from the gas well

- Biogas - any of the combustible gases produced from biological degradation of organic wastes - such as landfill gas, sewage digester gas, and animal waste digester gas

- Industrial waste gases - flare gases and process off-gases from refineries, chemical plants, and steel mills

- Manufactured gases - typically low- and medium-Btu gas produced by gasification or pyrolysis processes.

Contaminants are a concern with some waste fuels, specifically acid gas components $\left(\mathrm{H}_{2} \mathrm{~S}\right.$, halogen acids $(\mathrm{HCl})$, hydrogen cyanide, ammonia, salts and metal-containing compounds, organic halogen-, sulfur-, nitrogen-, and silicon-containing compounds); and oils. In combustion, halogen and sulfur compounds form halogen acids, $\mathrm{SO}_{2}$, some $\mathrm{SO}_{3}$, and possibly $\mathrm{H}_{2} \mathrm{SO}_{4}$ emissions. The acids can also corrode downstream equipment. A substantial fraction of any fuel nitrogen will be oxidized into $\mathrm{NO}_{\mathrm{x}}$ in combustion. Solid particulates must be kept to very low concentrations to prevent corrosion and erosion of components. Various fuel scrubbing, droplet separation and filtration steps will be required if any fuel contaminant levels exceed manufacturer specifications. Landfill gas, in particular, often contains chlorine compounds, sulfur compounds, organic acids and silicon compounds, which often require pretreatment.

\subsection{Availability and Life}

Data on availability and reliability are not available at this time because of the lack of operating experience. However, STM Power indicates that mean time between failures for the first few $25 \mathrm{~kW}$ units is about 2,600 hours based on statistical evaluation of data. Also, the units are described as having a 40,000-hour life with preventive maintenance required every 8,000 hours. Economic life is claimed to be 10 years, implying two major overhauls. 


\subsection{Emission Characteristics}

Data on emissions from Stirling engines are preliminary because of limited field-demonstration experience.

\subsection{Control Options}

Preliminary results show a favorable outlook for achieving very low emissions. The combustor of a Stirling engine can be customized to obtain low emissions, as in the case of gas turbines, and to a lesser extent, microturbines. With a hot-end operating temperature of $1600^{\circ} \mathrm{F}$, the combustor needs to operate only a few hundred degrees hotter, which puts it in the lower end of the thermal $\mathrm{NO}_{\mathrm{x}}$ formation range. A number of $\mathrm{NO}_{\mathrm{x}}$-reducing techniques are available to the designers, such as lean burn, staged combustion, or flue-gas recirculation.

\subsection{System Emissions}

Table 3. Stirling Engine Emission Characteristics

\begin{tabular}{|l|c|}
\hline Emissions Characteristics & STM 4-260 \\
\hline Nominal Capacity, (kW) & 55 \\
Electrical Efficiency, (\%) & 28 \\
$\mathrm{NO}_{\mathrm{x}}, \mathrm{g} / \mathrm{bhp}-\mathrm{hr}$ & 0.15 \\
$\mathrm{NO}_{\mathrm{x}}, \mathrm{lb} / \mathrm{MWh}$ & 0.51 \\
$\mathrm{CO}, \mathrm{lb} / \mathrm{MWh}$ & 1 \\
$\mathrm{VOC}, \mathrm{lb} / \mathrm{MWh}$ & $<0.1$ \\
$\mathrm{CO}_{2}, \mathrm{lb} / \mathrm{MWh}$ & 1,480 \\
\hline
\end{tabular}

Source: STM Power, Inc.

\subsection{Key Technology Objectives}

Stirling engines have attracted many developers during the past four decades, including the U.S. Department of Energy (DOE) and Gas Research Institute (GRI). In the 1970s and 1980s, DOE and GRI cooperated on the development of a gas-fired, free-piston engine for residential heat pumps. While technical advances have been made in seals and hermetic coupling (for freepiston engines) and some technical performance goals have been met, a substantial investment in manufacturing development must be made for Stirling engine packages to be competitive in the market with established high-volume competitors, such as, primarily, reciprocating engines. 
A number of other companies have prototypes and plans, but have been unable to attract the investments needed to push forward. The exception is STM Power, which has been able to raise necessary capital from investors.

If a market develops, product development will first move toward creating larger engines and later toward improving efficiency. For higher efficiency, the working hot-end temperature must increase. This will involve high-temperature materials in the hot-end components. These materials exist now, but the benefits do not justify their expense.

Another area for efficiency improvement is the regenerator. Improving the effectiveness of the regenerator will increase the efficiency of the engine.

There probably will be more engineering advances in the engine seals, which will lower maintenance costs.

\subsection{Advanced Technology Projections}

The key challenge for Stirling engines in becoming accepted in the marketplace is cost and reliability. For Stirling engines to become a commercial commodity product - rather than a niche market technology - installed cost will have to come down significantly. Stirling engines will follow the model for microturbines, where it is generally thought that costs will decline as manufacturing volumes increase to 50,000 units per year (or more) worldwide, achieving an economy of scale similar to the automobile industry.

Other improvements that will increase their attractiveness for on-site power and CHP applications are as follows:

- After price reduction, an increase in available capacities will come. Stirling engine developers - like microturbine developers - seem to be concluding that the market in the 25 $\mathrm{kW}$ capacity will not be robust enough to support the manufacturing numbers required. STM Power plans to introduce a $55 \mathrm{~kW}$ in 2003 and eventually introduce a $300 \mathrm{~kW}$ model.

- Following cost reduction and size increases, performance (efficiency) increases are next. By that time, products will have matured and gravitated to customer-preferred sizes. If these sizes achieve adequately large manufacturing volumes, the manufacturers then may be able to focus on increasing hot-end temperatures and improving seal design. The first improvement is likely to be an increase in the hot-end temperature to $2000^{\circ} \mathrm{F}$, which should boost the efficiency into the upper $30 \%$ range.

- Catalytic combustors are just now becoming mature enough for commercial service. Should material reduction in $\mathrm{NO}_{\mathrm{x}}$ emissions below 9 ppmv $\mathrm{NO}_{\mathrm{x}}$ be sought, catalytic combustion may be employed. Catalytic combustion has been shown to achieve levels of less than 3 ppmv of $\mathrm{NO}_{x}$. Catalytic combustion technology is just entering commercial service on a 1.3 MW gas turbine and will need to be scaled down and reconfigured for use in Stirling engines. 
Table 4. Projected Stirling Evolution Through 2030

\begin{tabular}{|c|c|c|c|c|c|}
\hline Unit & Current Characteristics & 2005 & 2010 & 2020 & 2030 \\
\hline $55 \mathrm{~kW}$ & $\begin{array}{ll} & \text { Hand-built } \\
& \text { prototypes } \\
- & \text { Grid-parallel units }\end{array}$ & $\begin{array}{l}\text { - Price decrease due to } \\
\text { the establishment of } \\
\text { manufacturing } \\
\text { systems } \\
\text { - } \text { Grid-independent } \\
\text { model introduced }\end{array}$ & 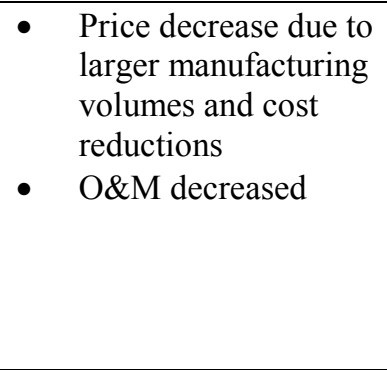 & $\begin{array}{l}\text { Price decrease due to } \\
\text { larger manufacturing } \\
\text { volumes and cost } \\
\text { reductions } \\
\text { - Efficiency increased to } \\
>35 \% \\
\text { - Engine life extended to } \\
10,000 \mathrm{hrs}\end{array}$ & $\begin{array}{ll}\text { - } & \text { Price decrease due to } \\
\text { larger manufacturing } \\
\text { volumes and cost } \\
\text { reductions } \\
\text { - } \quad \text { Engine life extended to } \\
10,000 / \mathrm{hr} \\
\text { - Material advances } \\
\text { allow increase in } \\
\text { efficiency to } \sim 40 \%\end{array}$ \\
\hline $75 \mathrm{~kW}$ & Not offered & Introduction & $\begin{array}{l}\text { - } \quad \text { Price decrease due to } \\
\text { larger manufacturing } \\
\text { volumes and cost } \\
\text { reductions }\end{array}$ & 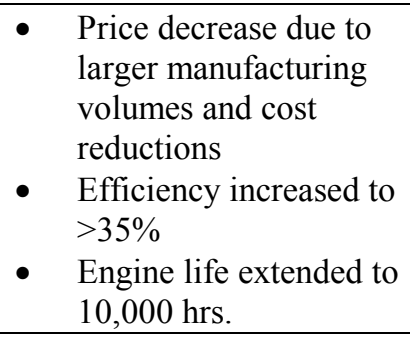 & $\begin{array}{ll}\text { - } & \text { Price decrease due to } \\
\text { larger manufacturing } \\
\text { volumes and cost } \\
\text { reductions } \\
\text { - } \quad \text { Efficiency increased to } \\
>40 \% \\
\text { - } \quad \text { Engine life extended to } \\
10,000 \mathrm{hrs}\end{array}$ \\
\hline $150 \mathrm{~kW}$ & Not offered & Not offered & Introduction & 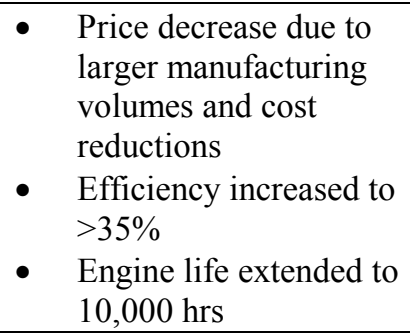 & $\begin{array}{ll}\text { - } & \text { Price decrease due to } \\
\text { larger manufacturing } \\
\text { volumes and cost } \\
\text { reductions } \\
\text { - } \quad \text { Efficiency increased to } \\
>40 \% \\
\text { - Engine life extended to } \\
10,000 \mathrm{hrs}\end{array}$ \\
\hline $300 \mathrm{~kW}$ & Not offered & Not offered & Introduction & $\begin{array}{l}\text { Price decrease due to } \\
\text { larger manufacturing } \\
\text { volumes and cost } \\
\text { reductions } \\
\text { Efficiency increased to } \\
>35 \%\end{array}$ & $\begin{array}{l}\text { Price decrease due to } \\
\text { larger manufacturing } \\
\text { volumes and cost } \\
\text { reductions } \\
\text { Efficiency increased to } \\
>40 \%\end{array}$ \\
\hline
\end{tabular}


Table 5. Current and Advanced Stirling Engine CHP System Characteristics

\begin{tabular}{|l|c|c|c|c|c|}
\hline $\begin{array}{l}\text { Cost and Performance Projections, } \\
\text { 55 kW Stirling engine CHP System }\end{array}$ & & & & & \\
\hline \multicolumn{1}{|c|}{ Year } & Current & & 2010 & 2020 & 2030 \\
\hline Nominal capacity, $\mathrm{kW}$ & 55 & 55 & 55 & 55 & 55 \\
\hline Total Installed Cost (2003 \$/kW) & 1,615 & 1,385 & 925 & 770 & 685 \\
\hline O\&M cost (2003 \$/kWh) & 0.008 & 0.005 & 0.005 & .004 & 0.003 \\
\hline CHP Characteristics & & & & & \\
\hline Electrical Efficiency (\%) & 28 & 28 & 28 & 35 & 40 \\
\hline CHP Efficiency (\%) & 74 & 74 & 74 & 80 & 85 \\
\hline
\end{tabular}

Note: Because there are no commercial units in production, these costs cannot be substantiated.

Source: STM Power, Inc.; installed cost developed by Antares Group, Inc. 


\section{REPORT DOCUMENTATION PAGE}

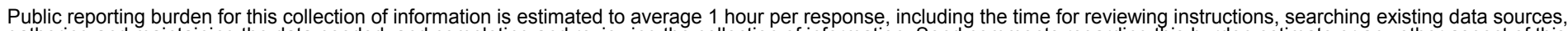

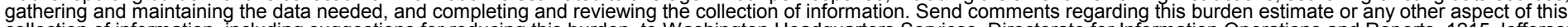
urden, to Washington Headquarters Services, Directorate Davis Highway, Suite 1204, Arlington, VA 22202-4302, and to the Office of Management and Budget, Paperwork Reduction Project (0704-0188), Washington, DC 20503.
1. AGENCY USE ONLY (Leave blank)
2. REPORT DATE
November 2003

\section{REPORT TYPE AND DATES COVERED}
Technical Report - Analysis

4. TITLE AND SUBTITLE

Gas-Fired Distributed Energy Resource Technology Characterizations

5. FUNDING NUMBERS

6. $\operatorname{AUTHOR}(\mathrm{S})$

Larry Goldstein, Bruce Hedman, Dave Knowles, Steven Freedman, Richard Woods,

and Tom Schweizer

7. PERFORMING ORGANIZATION NAME(S) AND ADDRESS(ES)

National Renewable Energy Laboratory

1617 Cole Blvd.

REPORT NUMBER

NREL/TP-620-34783

Golden, CO 80401-3393

TA: AS73.2002

10. SPONSORING/MONITORING AGENCY REPORT NUMBER

11. SUPPLEMENTARY NOTES

12a. DISTRIBUTION/AVAILABILITY STATEMENT

National Technical Information Service

12b. DISTRIBUTION CODE

U.S. Department of Commerce

5285 Port Royal Road

Springfield, VA 22161

13. ABSTRACT (Maximum 200 words)

The U. S. Department of Energy (DOE) Office of Energy Efficiency and Renewable Energy (EERE) is directing substantial programs in the development and encouragement of new energy technologies. Among them are renewable energy and distributed energy resource technologies. As part of its ongoing effort to document the status and potential of these technologies, DOE EERE directed the National Renewable Energy Laboratory to lead an effort to develop and publish Distributed Energy Technology Characterizations (TCs) that would provide both the department and energy community with a consistent and objective set of cost and performance data in prospective electric-power generation applications in the United States. Toward that goal, DOE/EERE - joined by the Electric Power Research Institute (EPRI) - published the Renewable Energy Technology Characterizations in December 1997. As a follow-up, DOE EERE - joined by the Gas Research Institute is now publishing this document, Gas-Fired Distributed Energy Resource Technology Characterizations.

14. SUBJECT TERMS
analysis; distributed energy resource; technology characterizations; Gas Research Institute; Gas Technology Institute; electric power; combined heat and power; reciprocating engines; small gas turbine systems; microturbine systems; fuel cell systems; small steam turbine systems; Stirling engine systems

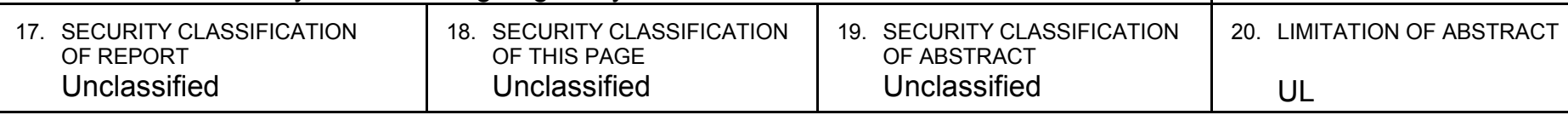


weatherization

fuel cell

Freedom CAR

solar 